\title{
Fatty acid-mediated gene expression in the cardiac muscle
}

Citation for published version (APA):

van der Lee, K. A. J. M. (2001). Fatty acid-mediated gene expression in the cardiac muscle. [Doctoral Thesis, Maastricht University]. Universiteit Maastricht. https://doi.org/10.26481/dis.20010621kl

Document status and date:

Published: 01/01/2001

DOI:

$10.26481 /$ dis.20010621kl

Document Version:

Publisher's PDF, also known as Version of record

\section{Please check the document version of this publication:}

- A submitted manuscript is the version of the article upon submission and before peer-review. There can be important differences between the submitted version and the official published version of record.

People interested in the research are advised to contact the author for the final version of the publication, or visit the DOI to the publisher's website.

- The final author version and the galley proof are versions of the publication after peer review.

- The final published version features the final layout of the paper including the volume, issue and page numbers.

Link to publication

\footnotetext{
General rights rights.

- You may freely distribute the URL identifying the publication in the public portal. please follow below link for the End User Agreement:

www.umlib.nl/taverne-license

Take down policy

If you believe that this document breaches copyright please contact us at:

repository@maastrichtuniversity.nl

providing details and we will investigate your claim.
}

Copyright and moral rights for the publications made accessible in the public portal are retained by the authors and/or other copyright owners and it is a condition of accessing publications that users recognise and abide by the legal requirements associated with these

- Users may download and print one copy of any publication from the public portal for the purpose of private study or research.

- You may not further distribute the material or use it for any profit-making activity or commercial gain

If the publication is distributed under the terms of Article $25 \mathrm{fa}$ of the Dutch Copyright Act, indicated by the "Taverne" license above, 


\title{
FATTY ACID-MEDIATED GENE EXPRESSION IN THE CARDIAC MUSCLE
}

\author{
PROEFSCHRIFT \\ ter verkrijging van de graad van doctor aan \\ de Universiteit Maastricht, \\ op gezag van de Rector Magnificus, \\ Prof.dr. A.C. Nieuwenhuijzen Kruseman, \\ volgens het besluit van het College van Decanen, \\ in het openbaar te verdedigen \\ op donderdag 21 juni 2001 om 14.00 uur \\ door
}

Karin Antonetta Johanna Maria van der Lee geboren te Veghel, op 4 februari 1973 


\section{Promotor:}

Prof.dr. G.J. van der Vusse

\section{Co-promotor:}

Dr. M. van Bilsen

\section{Beoordelingscommissie:}

Prof.dr. M. Borgers (voorzitter)

Prof.dr. M.H. Hofker

Prof.dr.ir. W.H.M. Saris

Prof.dr. J.F.M. Smits

Prof.dr. B. Staels (Université de Lille, France)

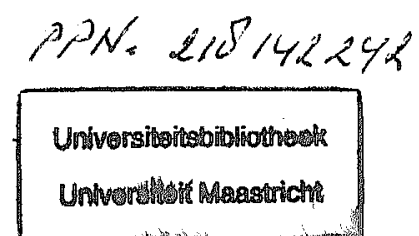

Financial support by the Netherlands Heart Foundation for the publication o this thesis is gratefully acknowledged.

Additional support was granted by SanverTech BV (Heerhugowaard, th Netherlands). 
Voor

mijn ouders 


\section{Contents}

\section{CHAPTER 1}

General introduction

CHAPTER 2

Fatty acid-regulated gene expression in the heart: involvement of peroxisome proliferator-activated receptors

CHAPTER 3

Long-chain fatty acid-induced changes in gene expression in neonatal cardiac myocytes

CHAPTER 4

PPAR $\alpha$ and PPAR $\beta / \delta$ modulate expression of cardiac genes coding for fatty acid-handling proteins

CHAPTER 5

Effects of fatty acids on uncoupling protein-2 expression in the rat heart

CHAPTER 6

Fasting-induced changes in the expression of genes controlling substrate metabolism in the rat heart

CHAPTER 7

General discussion

Abbreviations

Summary

Samenvatting

Samenvatting voor niet-vakgenoten

Publications

Curriculum vitae

Dankwoord 


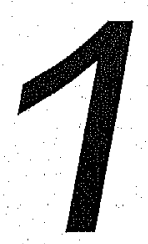

General introduction 
The rhythmic contraction of the heart guarantees adequate supply of blood to all organs in the body. In order to sustain its activity the cardiac muscle is dependent on a continuous supply of oxygen and nutrients. These are provided via the coronary arteries, which are perfused with oxygen-rich blood directly flowing from the aorta. The heart consumes different substrates, including fatty acids, glucose, lactate and ketone bodies. Under normal conditions glucose and fatty acids are the major fuels for the heart, fatty acids covering up to $70 \%$ of the energy need of the normal heart [69]. The contribution of fatty acids to cardiac energy production may alter under different physiological and pathophysiological conditions. For example, during fasting and diabetes the relative contribution of fatty acids to cardiac metabolism increases, whereas during cardiac hypertrophy and ischaemia the utilisation of fatty acids as an energy source in the heart has been shown to decline $[2,20,33,38,42]$.

\section{Fatty acid transport and metabolism}

In the blood, fatty acids are transported as unesterified molecules bound to albumin or in the esterified form as triacylglycerols or phospholipids in chylomicrons and other lipoproteins. In the heart fatty acids are released from chylomicrons and very lowdensity lipoproteins by lipoprotein lipase (LPL), located at the luminal surface of the endothelial cell membrane (Fig. 1.1). After passing the endothelium, fatty acids cross the interstitial space between the endothelial cells and cardiomyocytes via albuminmediated diffusion.

To enter cardiomyocytes long-chain fatty acids have to cross the sarcolemmal membrane either via passive diffusion or via a facilitated process mediated by membrane bound proteins (Fig. 1.1). At present, three proteins putatively involved in facilitated fatty acid membrane transport in the heart have been described, the plasma membrane fatty acid-binding protein ( $\left.F A B P_{1, m}\right)$, fatty acid translocase (FAT; homologue to CD36), and fatty acid transport protein (FATP) $[1,58,64,70]$. The transport of fatty acids to various subcellular sites in the cardiomyocyte can subsequently be facilitated by the heart-type fatty acid binding protein (H-FABP) $[57,63]$.

In order to become metabolised, fatty acids first have to be activated by acyl-CoA synthetase (ACS), which links the fatty acyl chain to coenzyme A (CoA; Fig. 1.1). The fatty acyl-CoA esters may then enter several pathways, including incorporation in membrane phospholipids and storage in triacylglycerol pools. In the heart, however, the majority of fatty acyl-CoA esters are further metabolised for the production of energy in a process referred to as fatty acid $\beta$-oxidation. The $\beta$-oxidation of activated fatty acids occurs in peroxisomes and mitochondria. Peroxisomes are small singlemembrane organelles named for their ability to produce and degrade hydrogen peroxide. Whereas only long-chain or very long-chain fatty acids can be subjected to the incomplete $\beta$-oxidation in peroxisomes, long-chain and short-chain fatty acids can be oxidised in mitochondria. The fatty acyl moieties enter the mitochondrial matrix via a carnitine-dependent shuttle mechanism (Fig. 1.1). In the heart, the muscle-type carnitine palmitoyl transferase 1 (mCPT1) is involved in the first step of this transport mechanism. During mitochondrial $\beta$-oxidation the fatty acyl-CoA ester is shortened in 


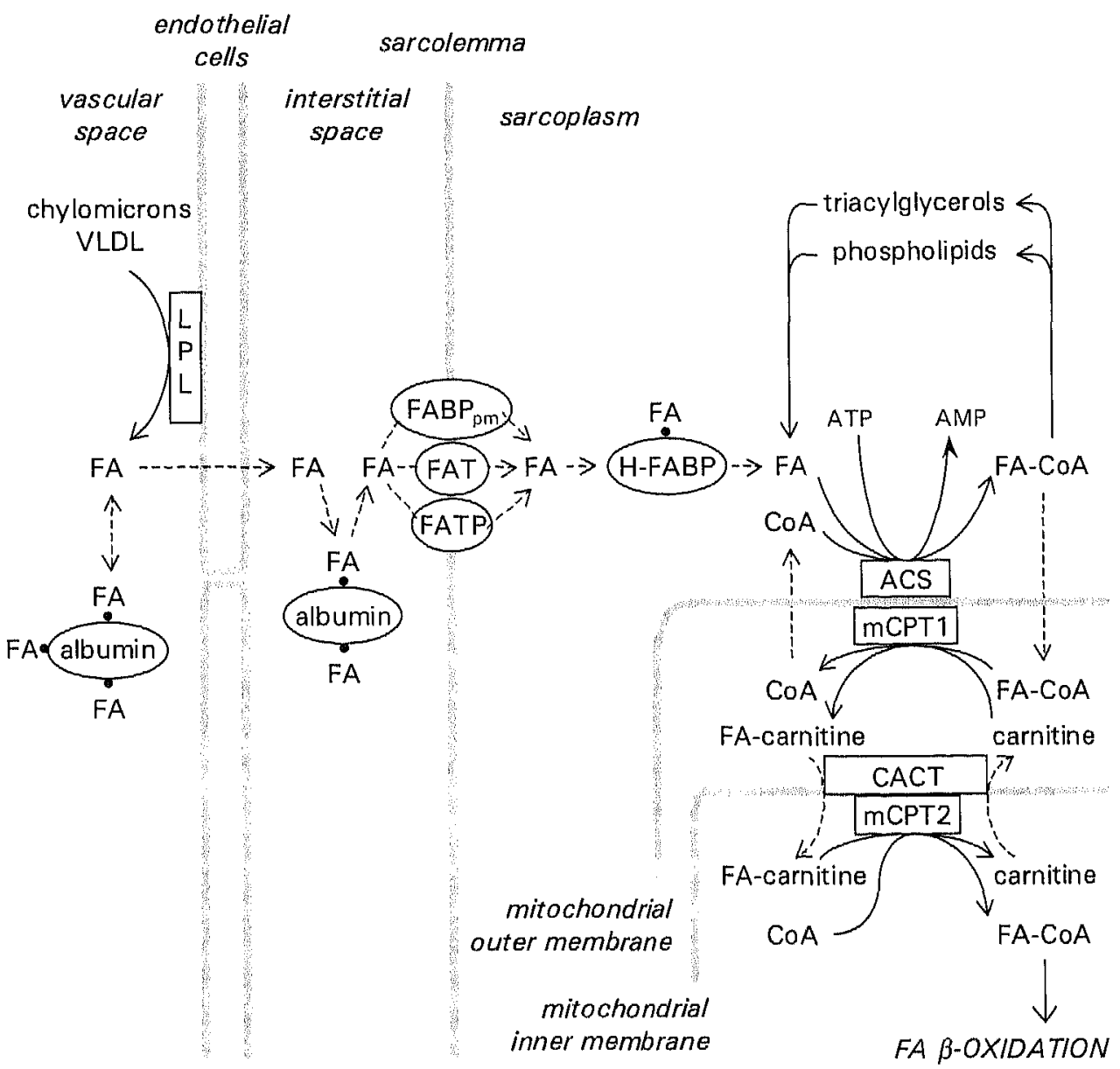

Figure 1.1 Schematic representation of fatty acid (FA) uptake and transport from the vascular space into mitochondria of cardiomyocytes. VLDL, very low-density lipoproteins; LPL, lipoprotein lipase; FABP acid transport protein; H-FABP, heart-type fatty acid-binding protein; $C O A$, coenzyme $A ; A C S$, acylCoA synthetase; mCPT, muscle-type carnitine palmitoyl transferase; CACT, carnitine-acylcarnitine translocase.

a stepwise manner and acetyl-CoA is generated (Fig. 1.2). Several reaction steps are included in this process, catalysed by a variety of enzymes. Long-chain acyl-CoA dehydrogenase (LCAD) is required for the first step of the $\beta$-oxidation of long-chain fatty acids. In one of the subsequent steps of the $\beta$-oxidation pathway 3-hydroxyacylCoA dehydrogenase (HAD) is involved. The generated acetyl-CoA moieties enter the citric acid cycle where they are further metabolised. Citrate synthase is a key enzyme in the citric acid cycle concerned with the generation of citrate from oxaloacetate and acetyl-CoA. At several steps in the $\beta$-oxidation process and in the citric acid cycle 


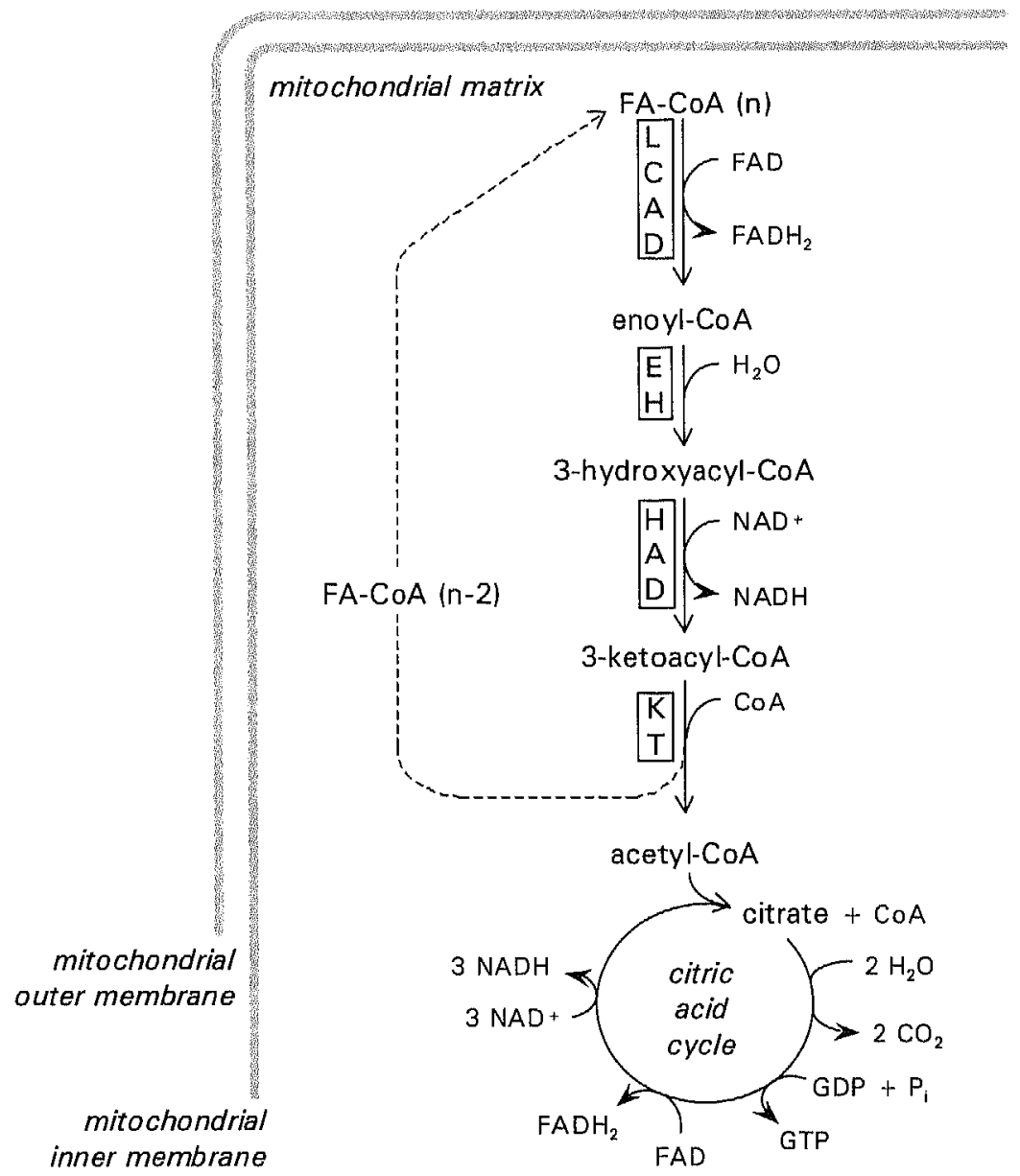

Figure 1.2 Schematic representation of mitochondrial fatty acid (FA) $\beta$-oxidation. For the sake clarity protons ar not indicated. LCAD, long-chain acyl-CoA dehydrogenase; $\mathrm{EH}$, enoyl-Co hydratase; HAD, 3-hydroxyacyl-COA dehydrogenase; KT, 3-ketothiolase; FAD, flavine adenin dinucleotide; NAD', nicotinamide adenine dinucleotide; $P_{i}$, inorganic phosphate; GTP, guanosin triphosphate.

reducing equivalents in the form of $\mathrm{FADH}_{2}$ and $\mathrm{NADH}$ are generated, an subsequently channelled into the respiratory chain.

\section{Glucose transport and metabolism}

Next to fatty acids, carbohydrates like glucose are important substrates for the hear Because of its hydrophilic nature glucose cannot enter the cardiomyocyte via passiv diffusion but is transported across the sarcolemma by glucose transporters (Figure 1.3 


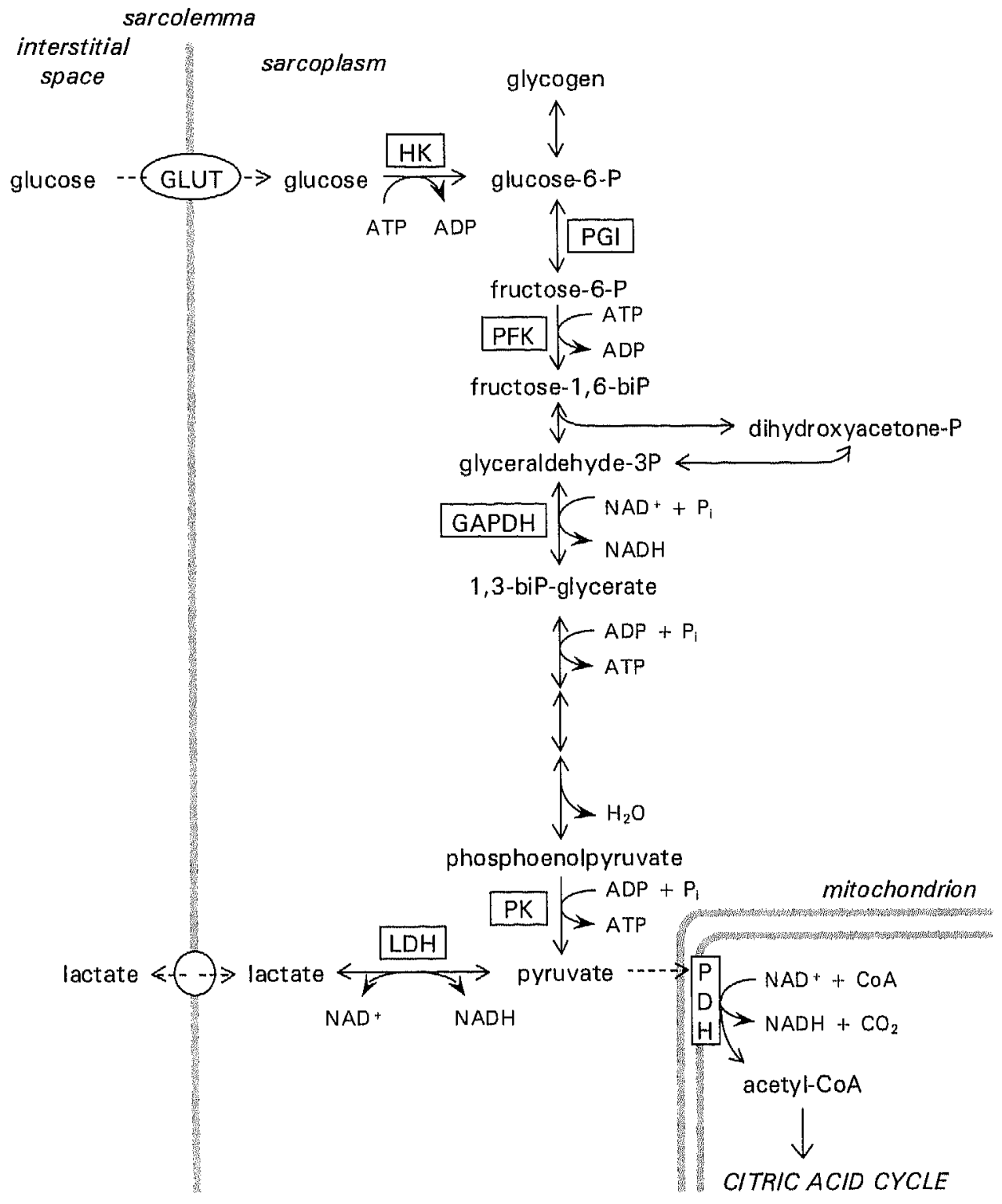

Figure 1.3 Simplified overview of glucose transport and metabolism in cardiomyocytes. For the sake of clarity protons are not indicated. GLUT, glucose transporter; HK, hexokinase; PGI, phosphoglucose isomerase; PFK, phosphofructokinase; GAPDH, glyceraldehyde-3-phosphate dehydrogenase; PK, pyruvate kinase; $\mathrm{LDH}$, lactate dehydrogenase; $\mathrm{PDH}$, pyruvate dehydrogenase; $N A D^{+}$, nicotinamide adenine dinucleotide; $\mathrm{P}_{i}$, inorganic phosphate; $\mathrm{CoA}$, coenzyme $A$. 
At least two glucose transporters are present in the heart, GLUT1 and GLUT4 [77]. GLUT1 is constitutively present in the membrane of the cell, whereas GLUT4 translocates to the sarcolemma from intracellular vesicles as a response to various stimuli, including insulin. Inside the cell glucose is converted into glucose-6phosphate by hexokinase of which two isozymes are present in the heart, hexokinase I and II (HKI and HKII). GLUT1 and HKI are most abundantly present in the foetal heart, whereas GLUT4 and HKII are predominantly expressed in the adult myocardium $[45,56,72]$. Glucose-6-phosphate can subsequently enter different metabolic routes, including formation of glycogen and the glycolytic pathway. Through glycolysis glucose-6-phosphate is metabolised into pyruvate (Fig. 1.3). 6Phosphofructo-1-kinase (PFK) is an important regulatory enzyme in this glycolytic pathway. Glyceraldehyde-3-phosphate dehydrogenase (GAPDH) is also involved in the conversion of glucose into pyruvate. Pyruvate can subsequently be converted into lactate by lactate dehydrogenase (LDH) when oxygen supply is limited (anaerobic glycolysis) or transported into the mitochondrion where it is converted into acetyl$\mathrm{COA}$ by the pyruvate dehydrogenase (PDH) complex. Acetyl-CoA eventually enters the citric acid cycle for further metabolisation (oxidative glucose metabolism).

\section{Oxidative phosphorylation}

The major part of ATP produced during fatty acid and glucose oxidation is generated by oxidative phosphorylation. Oxidative phosphorylation occurs at the inner membrane of the mitochondrion, where $\mathrm{NADH}$ and $\mathrm{FADH}_{2}$, which are formed during fatty acid $\beta$-oxidation, glycolysis, and in the citric acid cycle, are oxidised and ADP is phosphorylated in order to produce energy in the form of ATP. These oxidation and phosphorylation processes are coupled by an electrochemical proton gradient (Fig. 1.4). The respiratory chain, consisting of three enzyme complexes and two mobile electron carriers, is the functional unit that oxidises NADH and FADH $\mathrm{F}_{2}$. The transfer of electrons from $\mathrm{NADH}$ and $\mathrm{FADH} \mathrm{H}_{2}$ to oxygen results in pumping of protons from the mitochondrial matrix towards the intermembrane space. The electrochemical gradient generated in this way (also called proton-motive force) is subsequently used by ATPsynthase to produce ATP from ADP and inorganic phosphate $\left(\mathrm{P}_{\mathrm{i}}\right)$.

\section{Uncoupling proteins}

The production of energy by ATP-synthase is dependent on the electrochemical proton gradient across the mitochondrial inner membrane generated by the respiratory chain. When protons move back from the intermembrane space towards the mitochondrial matrix without passing ATP-synthase, oxidative phosphorylation is said to be uncoupled. Controlled uncoupling of oxidative phosphorylation causes heat production in brown adipose tissue (BAT), an organ concerned with nonshivering thermogenesis and present in almost all mammals. A protein expressed in the inner mitochondrial membrane of BAT is responsible for the controlled 


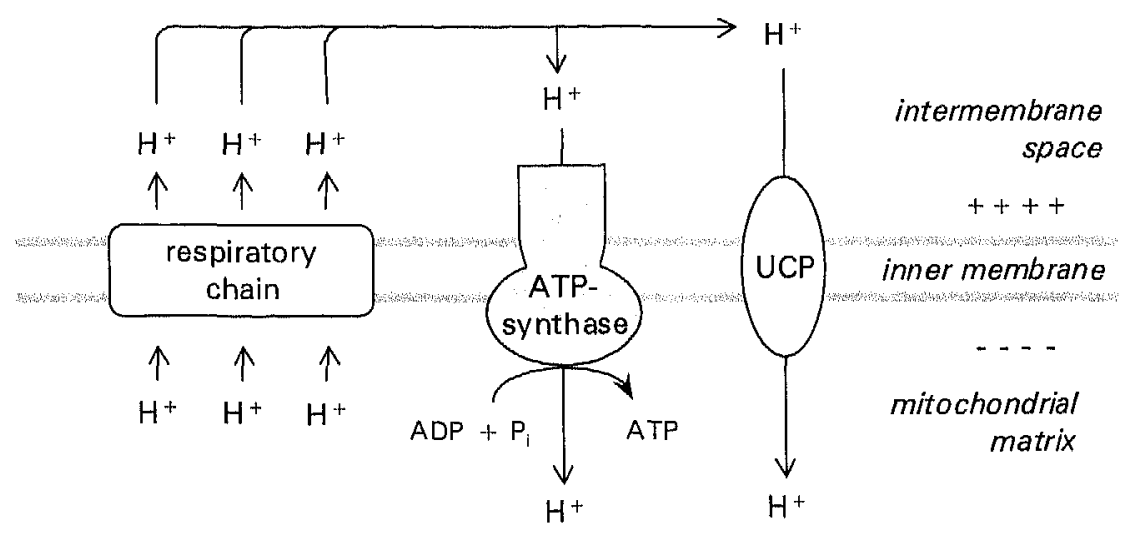

Figure 1.4 Proton transport across the inner mitochondrial membrane. The respiratory chains moves protons from the mitochondrial matrix into the intermembrane space of the mitochondrion. ATP synthase makes use of the proton motive force in order to produce energy, whereas the uncoupling protein (UCP) transports protons without generation of ATP. $\mathrm{P}_{\mathrm{i}}$, inorganic phosphate.

uncoupling. This protein, called uncoupling protein-1 (UCP-1), is able to transport protons across the inner membrane towards the mitochondrial matrix and thus to decrease the electrochemical proton gradient (Fig. 1.4) [36,50]. UCP-1 is solely expressed in BAT and plays an important role in adaptive thermogenesis $[13,36]$.

The interest in uncoupling proteins grew when homologues of UCP-1 (until then called UCP) were found in tissues other than BAT. Presently, four mammalian isoforms of UCP-1 have been described. UCP-2 is ubiquitously distributed [15,21] and UCP-3 is expressed mainly in skeletal muscle and brown adipose tissue $[8,71]$. The very recently described UCP-4 is restricted to brain [39] and UCP-5 (originally referred to as brain mitochondrial carrier protein-1 or BMCP1) is present in multiple tissues with high abundance in brain and testis $[55,74]$. In the heart, UCP-2, UCP-3 and UCP5 are expressed, with UCP-2 being most abundant.

\section{Function of uncoupling proteins}

The exact mechanism by which uncoupling proteins transport protons across the mitochondrial inner membrane is still a matter of debate. For UCP-1 it is generally accepted that fatty acids activate and purine di- and trinucleotides inhibit the uncoupling activity [49]. At present, two mechanisms of action have been hypothesised. The first one, originally proposed by Skulachev [61] and later modified by Garlid and Ježek [18], states that uncoupling proteins move protons by cycling of fatty acids in the mitochondrial inner membrane (Fig. 1.5A). In this model UCP translocates anionic fatty acids from the matrix side towards the side of the mitochondrial intermembrane space, where fatty acids can be protonated. Protonated fatty acids flip-flop across the inner membrane and subsequently release protons into the mitochondrial matrix. The anionic fatty acids can enter the cycle again starting with translocation by UCP. In the second model, proposed by Klingenberg [36,73], 
A

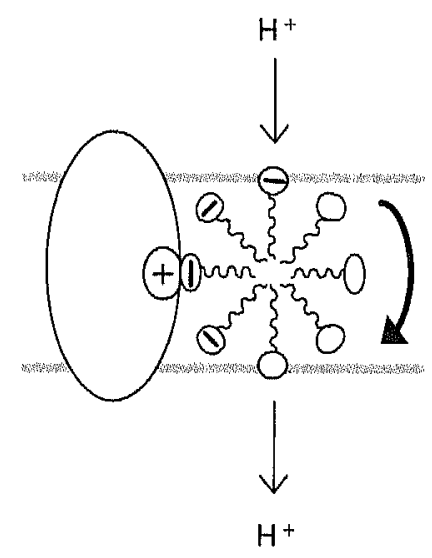

B

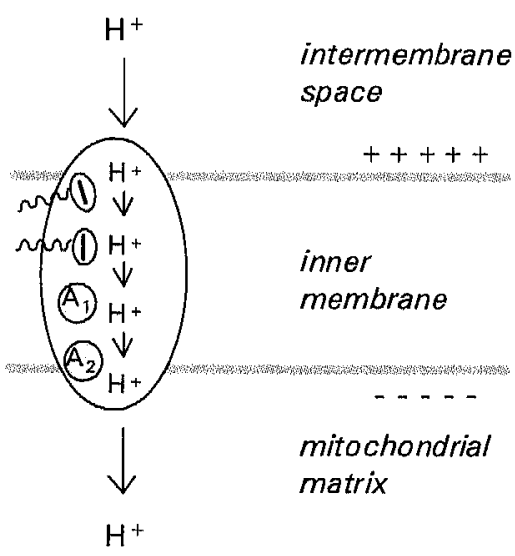

Figure 1.5 Schematic representations of two hypothetical mechanisms of proton transport b uncoupling protein (UCP). A. Proton transport via fatty acid cycling (adapted from [30]). B. Proto transport with fatty acids acting as cofactors (adapted from [36]). $A_{1}$ and $A_{2}$, intrinsic proto acceptor/donor groups. For explanations see text.

protons are transported via a proton pathway in UCP by use of intrinsic protor acceptor/donor groups (Fig. 1.5B). Here, fatty acids act as cofactors to facilitate protor transport across the mitochondrial inner membrane.

As for UCP-2 and UCP-3, several studies, using recombinant yeast and mammaliar cells, have shown that they are indeed able to uncouple oxidative phosphorylation $[7,15,23,28,37]$. Moreover, catalysation of a proton flux was found in liposome reconstituted with purified UCP-2 or UCP-3 [29]. Whether UCP-2 and -3 can be activated by fatty acids and inhibited by purine di- and trinucleotides is still discussed Fatty acids were demonstrated to be obligatory for UCP-2 and -3 to exert thei uncoupling function in reconstituted liposomes [29], but did not increase protor transport when yeast mitochondria expressing UCP-2 or UCP-3 were used [48]. Twe groups independently reported inhibition of proton transport following addition o nucleotides [12,29], whereas others described the absence of an inhibitory effect o these compounds $[48,75]$. Recently, in an elegant study comparing chimeric protein of UCP-1 and UCP-3, Hagen and Lowell [26] were not able to demonstrate effects o both fatty acids and GDP with respect to UCP-3 activity.

Although the role for UCP-1 has been established many years ago, the functions o the other UCP isoforms are basically unknown. For UCP-2 and UCP-3 several role: have been suggested (for reviews see [6,49]). Like UCP-1, UCP-2 and -3 may be involved in non-shivering thermogenesis. However, at this moment there is little evidence for a role of these uncoupling proteins in the response to cold exposure though they might play a role in the thermogenic mechanism of fever $[14,49]$ Another possible role for UCP-2 and -3 could be reducing the production of reactive oxygen species by mitochondria. By decreasing the electrochemical proton gradient 
transport of electrons through the respiratory chain is stimulated, which consequently results in decreased half-lives of intermediates capable of generating superoxide anions, on the one hand. On the other hand, the cellular levels of oxygen, the substrate for superoxide anions, are reduced [62]. Alternatively, UCP-2 and -3 may preserve a constant flux through the metabolic pathways by maintaining a relatively high flux of protons across the mitochondrial inner membrane. In this way, the cell will be able to respond immediately to an increased demand of energy without the need to activate its metabolic routes first, e.g. during acute exercise. By a switch in proton flux from uncoupling proteins towards ATP-synthase, the ATP turnover can thus be increased [9]. Finally, UCP-2 and UCP-3 have been suggested to be involved in the regulation of fatty acid metabolism $[5,53]$. Indications for this role are the increased UCP-2 and -3 mRNA transcripts in skeletal muscle when circulating fatty acid levels as well as fatty acid utilisation are enhanced, like during fasting and highfat feeding, and the downregulation of UCP-2 and UCP-3 mRNA during subsequent refeeding [40,52-54].

\section{Cardiac metabolism and pathophysiology}

As stated earlier, cardiac metabolism varies under different physiological and pathological conditions. Interestingly, conditions in which the utilisation of fatty acids by the heart is increased, like during postnatal development and fasting, are accompanied by rises in circulating fatty acid levels. Fatty acid levels increase in the blood after birth, as soon as the newborn animal starts drinking lipid-rich mother's milk [22]. During fasting, fatty acids are released by the adipose tissue in order to provide the body with substrates [43]. This is indicative for a role of fatty acids in the modulation of cardiac metabolism. However, conditions in which the utilisation of fatty acids is decreased, like cardiac hypertrophy and heart failure, are generally not associated with decreased fatty acids levels in the blood. Since less oxygen is needed to produce a certain amount of energy from glucose than from fatty acids, and the supply of oxygen may become limited by high workload and increased diffusion distances due to decreased capillary density [66], it seems logical that the heart prefers glucose under these pathological conditions. Interestingly, hypertrophied cardiomyocytes re-express proteins of the foetal stage (reviewed in [67]), e.g. the adult form of the contractile protein myosin heavy chain, MyHC $\alpha$, is replaced by its foetal isoform, MyHC $\beta$. The shift in substrate utilisation in the hypertrophied or failing heart may also be considered as part of the recapitulation of the foetal gene expression program, since glucose is the preferred substrate of foetal cardiomyocytes.

Alterations in cardiac substrate utilisation are features of the above mentioned physiological and pathological conditions. Conversely, changes in cardiac metabolism may result in cardiac diseases. Inhibition of fatty acid oxidation in rats by treatment with etomoxir, an inhibitor of CPT1, results in cardiac hypertrophy [51]. The same holds for feeding rats a fat-free diet [44]. In addition, inborn errors of metabolic processes like fatty acid oxidation and oxidative phosphorylation are important causes of inherited cardiomyopathies [34]. 


\section{Regulation of metabolism and metabolic genes}

The metabolism of fatty acids and glucose can be regulated in several ways. In general it can be stated that catabolic pathways are activated when energy (ATP) is needed, whereas a high level of ATP decreases their activity. In addition, a metabolic relationship between glucose and fatty acids, called the glucose-fatty acid cycle or Randle cycle, exists. Randle and co-workers $[46,47]$ demonstrated that on the one hand an enhanced glucose supply promotes glucose oxidation and inhibits fatty acid oxidation, whereas on the other hand an increased supply of fatty acids promotes fatty acid oxidation and inhibits glucose utilisation. Regulation of fatty acid and glucose metabolism at the enzyme level occurs by various mechanisms. First, the activities of enzymes alter in response to changes in metabolite concentrations. When substrate concentration rises, the conversion rate increases. Metabolic products may also give a negative feedback, e.g. hexokinase activity is inhibited by its product glucose-6phosphate. Furthermore, metabolites may allosterically interact with enzymes, thus PFK is allosterically inhibited by ATP and citrate. Second, enzyme activity can be modulated by covalent modification. For example, the PDH complex is inhibited by phosphorylation. Third, the cellular amount of enzymes can be adjusted. This can be achieved by altering the rate at which mRNA is formed (transcription), mRNA stability, the rate at which mRNA is converted into protein (translation), or by altering protein stability. Generally speaking, adjustment of enzyme levels needs a longer time scale, i.e. in the order of hours or days.

Hormones like insulin and thyroid hormone are factors known to be able to regulate the expression of metabolic genes $[4,27,76]$. Recently, several studies have shown that substrates themselves, among which glucose and fatty acids, are able to modulate gene expression $[17,32,68]$. Moreover, regulatory sequences responsive to glucose and fatty acids have been found in the promoter regions of metabolic genes $[3,60]$. As for fatty acids, they have been shown to interact with a group of transcription factors of the family of nuclear hormone receptors, called peroxisome proliferator-activated receptors (PPARs) $[16,24,31,35]$. The PPARs play a major role in the regulation of lipid metabolism, since they affect the transcription of many proteins involved in extracellular and intracellular lipid metabolism [11,19,59]. More information about PPARs can be found in chapter 2 of this thesis, in which the role of fatty acids in the regulation of gene expression in the heart is reviewed. In this chapter, the involvement of fatty acids and PPARs in cardiac pathophysiology is discussed as well.

\section{Research questions and hypotheses}

At the start of this project, others already showed that fatty acids are able to act as signalling molecules in the regulation of metabolic gene expression in cultured liver cells, adipocytes, and skeletal myocytes $[10,25,41,65]$. Since oxidation of fatty acids is an important source of energy for the heart, we wondered whether fatty acids could also modulate gene expression in cardiomyocytes. If the expression of genes coding 
for proteins involved in glucose and fatty acid metabolism is altered indeed, is this then accompanied with changes in cardiomyocyte metabolism? Which molecular mechanisms mediate the fatty acid-induced changes in cardiac gene expression? Are PPARs perhaps involved? To elucidate these questions cultured neonatal rat cardiomyocytes can be applied, but is it possible to use a heart-derived cell line as an alternative cellular model? During the course of the study, the interest in uncoupling proteins grew. Since UCP-2 is highly expressed in the heart and is suggested to play a role in lipid metabolism, we asked whether fatty acids also induce the expression of this novel protein. Finally, the question was raised whether fatty acids are able to modulate cardiac gene expression in vivo as well.

To answer these questions the following hypotheses were formulated:

1. Fatty acids modulate gene expression in cultured neonatal cardiomyocytes, in particular, those genes coding for proteins involved in fatty acid transport and metabolism are upregulated.

2. A fatty acid-induced increase in the expression of genes encoding fatty acidhandling proteins in cardiomyocytes is accompanied with an increased fatty acid oxidation capacity.

3. PPARs mediate fatty acid-regulated gene expression in cardiomyocytes.

4. Embryonic rat heart-derived $\mathrm{H} 9 \mathrm{c} 2$ cells can be used as an alternative model for neonatal rat cardiomyocytes.

5. Cardiac uncoupling protein-2 expression is stimulated by fatty acids.

6. An augmentation of circulating fatty acid levels in vivo also results in increased expression of genes coding for fatty acid-handling proteins in the heart.

\section{Outline of thesis}

In this thesis, several studies are presented testing the above mentioned hypotheses.

In chapter 3 a study is described in which isolated neonatal rat cardiomyocytes were used to investigate the effects of fatty acids. These heart muscle cells were cultured in the presence of glucose, fatty acids, or a combination of both substrates. The effects of fatty acids on cardiomyocyte phenotype, substrate storage, gene expression of metabolic proteins, and fatty acid oxidation were examined. In addition, it was tested whether specific PPAR $\alpha$ and PPAR $\gamma$ activators could regulate neonatal cardiomyocyte gene expression.

In chapter 4 a comparison has been made between neonatal rat cardiomyocytes and the cardiac-derived $\mathrm{H} 9 \mathrm{c} 2$ cell line with respect to the effects of fatty acids on metabolic gene expression and the role of PPARs herein. The question was addressed whether PPAR $\alpha, \operatorname{PPAR} \beta / \delta$ and/or PPAR $\gamma$ may mediate the fatty acid-induced effects in the heart.

It has been suggested that uncoupling proteins may regulate fatty acid metabolism and that fatty acids may modulate the activity of uncoupling proteins. This, together with the demonstration that fatty acids increase the expression of genes coding for proteins involved in fatty acid metabolism, resulted in chapter 5. This chapter describes the potential role that fatty acids have in the regulation of uncoupling 
protein-2 gene expression in the rat heart. UCP-2 expression was examined in vitro in neonatal cardiomyocytes and $\mathrm{H} 9 \mathrm{C} 2$ cells but also in vivo under different (patho-) physiological conditions.

To determine whether the heart in vivo also responds to changes in substrate supply, adult rats were subjected to fasting. Fasting results in increased circulating levels of fatty acids and decreased levels of glucose. In addition, the utilisation of glucose by the heart declines whereas the contribution of fatty acids as a cardiac energy source rises [20,42]. Chapter 6 describes the fasting-induced metabolic changes in the heart at the level of enzyme activity, protein content and gene expression, and gives answer to the question whether an 8 hour treatment with the anti-lipolytic agent nicotinic acid reverses the fasting-induced responses.

Finally, in chapter 7 the implications of the major findings in this thesis are discussed and recommendations for future studies are given.

\section{References}

1. Abumrad NA, El-Maghrabi MR, Amri EZ, Lopez E, and Grimaldi PA (1993). Cloning of a rat adipocyte membrane protein implicated in binding or transport of long-chain fatty acids that is induced during preadipocyte differentiation. Homology with human CD36. / Biol Chem 268, 17665-17668

2. Allard MF, Schönekess BO, Henning SL, English DR, and Lopaschuk GD (1994). Contribution of oxidative metabolism and glycolysis to ATP production in hypertrophied hearts. Am / Physiol 267, H742-H750

3. Amri E-Z, Bonino F, Ailhaud G, Abumrad NA, and Grimaldi PA (1995). Cloning of a protein that mediates transcriptional effects of fatty acids in preadipocytes. Homology to peroxisome proliferator-activated receptors. / Biol Chem 270, 2367-2371

4. Bernal J, and Refetoff $S$ (1977). The action of thyroid hormone. Clin Endocrinol 6, 227-249

5. Boss O, Bobbioni-Harsch E, Assimacopoulos-Jeannet F, Muzzin P, Munger R, Giacobino J-P, and Golay A (1998). Uncoupling protein-3 expression in skeletal muscle and free fatty acids in obesity. Lancet 351,1933

6. Boss O, Hagen T, and Lowell BB (2000). Uncoupling proteins 2 and 3: potential regulators of mitochondrial energy metabolism. Diabetes 49, 143-156

7. Boss O, Samec S, Kühne F, Bijlenga P, Assimacopoulos-Jeannet F, Seydoux J, Giacobino J-P, and Muzzin $P$ (1998). Uncoupling protein-3 expression in rodent skeletal muscle is modulated by food intake but not by changes in environmental temperature. / Biol Chem 273, 5-8

8. Boss O, Samec S, Paoloni-Giacobino A, Rossier C, Dulloo A, Seydoux J, Muzzin P, and Giacobino J-P (1997). Uncoupling protein-3: a new member of the mitochondrial carrier family with tissue-specific expression. FEBS Lett 408, 39-42

9. Brand MD, Chien LF, Ainscow EK, Rolfe DF, and Porter RK (1994). The causes and functions of mitochondrial proton leak. Biochim Biophys Acta 1187, 132-139

10. Chatelain F, Kohl C, Esser V, MCGarry JD, Girard J, and Pegorier J-P (1996). Cyclic AMP and fatty acids increase carnitine palmitoyltransferase I gene transcription in cultured fetal rat hepatocytes. Eur / Biochem 235, 789-798

11. Desvergne $B$ and Wahli W (1999). Peroxisome proliferator-activated receptors: nuclear control of metabolism, Endocr Rev 20, 649-688

12. Echtay KS, Liui $Q$, Caskey $T$, Winkler $E$, Frischmuth $K$, Bienengräber $M$, and Klingenberg $M$ (1999). Regulation of UCP3 by nucleotides is different from regulation of UCP1. FEBS Lett $450,8-12$ 
13. Enerbäck S, Jacobsson A, Simpson EM, Guerra C, Yamashita $H$, Harper ME, and Kozak LP (1997). Mice lacking mitochondrial uncoupling protein are cold-sensitive but not obese. Nature 387, 90-94

14. Faggioni R, Shigenaga J, Moser A, Feingold KR, and Grunfeld C (1998). Induction of UCP2 gene expression by LPS: a potential mechanism for increased thermogenesis during infection. Biochem Biophys Res Commun 244, 75-78

15. Fleury $C$, Neverova $M$, Collins $S$, Raimbault $S$, Champigny $O$, Levi-Meyrueis $C$, Bouillaud $F$, Seldin MF, Surwit RS, Ricquier D, and Warden CH (1997). Uncoupling protein-2: a novel gene linked to obesity and hyperinsulinemia. Nature Genet 15, 269-272

16. Forman BM, Chen J, and Evans RM (1997). Hypolipidemic drugs, polyunsaturated fatty acids, and eicosanoids are ligands for peroxisome proliferator-activated receptors $\alpha$ and $\delta$. Proc Natl Acad Sci USA 94, 4312-4317

17. Foufelle F, Girard J, and Ferré $P$ (1998). Glucose regulation of gene expression. Curr Opin Clin Nutr Metab Care 1, 323-328

18. Garlid KD, Orosz DE, Modriansky M, Vassanelli S, and Jezek P (1996). On the mechanism of fatty acid-induced proton transport by mitochondrial uncoupling protein. / Biol Chem 271, 2615-2620

19. Gervois P, Torra IP, Fruchart JC, and Staels B (2000). Regulation of lipid and lipoprotein metabolism by PPAR activators. Clin Chem Lab Med 38, 3-11

20. Ghezzi C, Dubois F, Mathieu JP, Cand F, Comet M, and Cuchet P (1990). Effect of short-term fasting on [123l] iodohexadecenoic acid metabolism in the isolated perfused rat heart. Validation of mathematical model by comparison with experimental measurements. Arch Int Physiol Biochim 98, 269-281

21. Gimeno RE, Dembski M, Weng X, Deng N, Shyjan AW, Gimeno Cl, Iris F, Ellis SJ, Woolf EA, and Tartaglia LA (1997). Cloning and characterization of an uncoupling protein homolog: a potential molecular mediator of human thermogenesis. Diabetes 46, 900-906

22. Girard J, Ferré P, Pégorier J-P, and Duée P-H (1992). Adaptations of glucose and fatty acid metabolism during perinatal period and suckling-weaning transition. Physiol Rev 72, 507-562

23. Gong D-W, He $Y$, Karas $M$, and Reitman $M$ (1997). Uncoupling protein-3 is a mediator of thermogenesis regulated by thyroid hormone, $\beta 3$-adrenergic agonists, and leptin. I Biol Chem $272,24129-24132$

24. Göttlicher M, Widmark E, Li Q, and Gustafsson J-Aं (1992). Fatty acids activate a chimera of the clofibric acid-activated receptor and the glucocorticoid receptor. Proc Nat/ Acad Sci USA $89,4653-4657$

25. Grimaldi PA, Knobel SM, Whitesell RR, and Abumrad NA (1992). Induction of aP2 gene expression by nonmetabolized long-chain fatty acids. Proc Natl Acad Sci USA 89, 1093010934

26. Hagen T and Lowell BB (2000). Chimeric proteins between UCP1 and UCP3: the middle third of UCP1 is necessary and sufficient for activation by fatty acids. Biochem Biophys Res Commun 276, 642-648

27. Hall RK and Granner DK (1999). Insulin regulates expression of metabolic genes through divergent signaling pathways. I Basic Clin Physiol Pharmacol 10, 119-133

28. Hinz W, Faller B, Grüninger S, Gazzotti $P$, and Chiesi $M$ (1999). Recombinant human uncoupling protein-3 increases thermogenesis in yeast cells. FEBS Lett 448, 57-61

29. Jaburek $M$, Varecha $M$, Gimeno RE, Dembski $M$, Jezek $P$, Zhang $M, B$ urn $P$, Tartaglia $L A$, and Garlid KD (1999). Transport function and regulation of mitochondrial uncoupling proteins 2 and 3. J Biol Chem 274, 26003-26007

30. Jezek P, Engstová $H$, Zácková M, Vercesi AE, Costa ADT, Arruda P, and Carlid KD (1998). Fatty acid cycling mechanism and mitochondrial unoupling proteins. Biochim Biophys Acta $1365,319-327$

31. Johnson TE, Holloway MK, Vogel R, Rutledge SJ, Perkins J\}, Rodan GA, and Schmidt A (1997). Structural requirements and cell-type specificity for ligand activation of peroxisome proliferator-activated receptors. / Steroid Biochem Molec Biol 63, 1-8 
32. Jump DB, Thelen $A$, and Mater $M$ (1999). Dietary polyunsaturated fatty acids and hepatic gene expression. Lipids 34, S209-\$212

33. Kagaya $Y$, Kanno $Y$, Takeyama D, Ishide N, Maruyama $Y$, Takahashi T, Ido T, and Takishima T (1990). Effects of long-term pressure overload on regional myocardial glucose and free fatty acid uptake in rats. A quantitative autoradiographic study. Circulation 81, 1353-1361

34. Kelly DP and Strauss AW (1994). Inherited cardiomyopathies. New Eng/ I Med 330, 913-919

35. Kliewer SA, Sundseth SS, Jones SA, Brown PJ, Wisely GB, Koble CS, Devchand P, Wahli W, Willson TM, Lenhard JM, and Lehmann JM (1997). Fatty acids and eicosanoids regulate gene expression through direct interactions with peroxisome proliferator-activated receptors $\alpha$ and \%. Proc Natl Acad Sci USA 94, 4318-4323

36. Klingenberg $M$ and Huang S-G (1999). Structure and function of the uncoupling protein from brown adipose tissue. Biochim Biophys Acta 1415, 271-296

37. Liu Q, Bai C, Chen F, Wang R, MacDonald T, Gu M, Zhang Q, Morsy MA, and Caskey CT (1998). Uncoupling protein-3: a muscle-specific gene upregulated by leptin in $a b / o b$ mice. Gene 207, 1-7

38. Lopaschuk GD (1992). Fatty acid metabolism in the heart following diabetes. In The heart in diabetes. Chatham JC, Forder JR, and MCNeill JH, Eds. Kluwer Academic Publishers, Boston, 215-251

39. Mao W, Yu XX, Zhong A, Li W, Brush J, Sherwood SW, Adams SH, and Pan G (1999). UCP4, a novel brain-specific mitochondrial protein that reduces membrane potential in mammalian cells. FEBS Lett 443, 326-330

40. Matsuda f, Hosoda $K$, Itoh $H$, Son $C$, Doi $K$, Tanaka $T$, Fukunaga $Y$, Inoue $G$, Nishimura $H$, Yoshimasa $Y$, Yamori $Y$, and Nakao K (1997). Cloning of rat uncoupling protein-3 and uncoupling protein-2 CDNA: their gene expression in rats fed high-fat diet. FEBS Lett 418, 200204

41. Meunier-Durmort C, Poirier H, Niot I, Forest C, and Besnard P (1996). Up-regulation of the expression of the gene for liver fatty acid-binding protein by long-chain fatty acids. Biochem $J$ $319,483-487$

42. Opie LH (1991). Fuels: Carbohydrates and lipids. In The heart: Physiology and metabolism. Eds. Raven Press, New York, 208-246

43. Owen OE, Reichard GA, Jr., Patel MS, and Boden G (1979). Energy metabolism in feasting and fasting. Adv Exp Med Biol 111, 169-188

44. Panos TC and Finerty JC (1953). Effects of a fat-free diet on growing female rats, with special reference to the endocrine system. I Nutr 49, 397-423

45. Postic C, Leturque A, Printz RL, Maulard P, Loizeau M, Granner DK, and Girard J (1994). Development and regulation of glucose transporter and hexokinase expression in rat. Am J Physiol 266, E548-559

46. Randle PJ (1998). Regulatory interactions between lipids and carbohydrates: the glucose fatty acid cycle after 35 years. Diabetes Metab Rev 14, 263-283

47. Randle P], Hales CN, Garland PB, and Newsholme EA (1963). The glucose fatty acid cycle. Its role in insulin sensitivity and the metabolic disturbances of diabetes mellitus. Lancet 34, 785789

48. Rial E, Gonzalez-Barroso M, Fleury C, Iturrizaga S, Sanchis D, Jiménez-Jiménez J, Ricquier D, Goubern $M$, and Bouillaud $F$ (1999). Retinoids activate proton transport by the uncoupling proteins UCP1 and UCP2. EMBO/ 18, 5827-5833

49. Ricquier D and Bouillaud $F$ (2000). The uncoupling protein homologues: UCP1, UCP2, UCP3, StUCP and AtUCP. Biochem / 345 Pt 2, 161-179

50. Ricquier D, Casteilla $L$, and Bouillaud F (1991). Molecular studies of the uncoupling protein. FASEB / 5, 2237-2242

51. Rupp $H$ and Jacob R (1992). Metabolically-modulated growth and phenotype of the rat heart. Eur Heart ) 13, 56-61 
52. Samec S, Seydoux 1, and Dulloo AG (1998). Interorgan signaling between adipose tissue metabolism and skeletal muscle uncoupling protein homologs. Is there a role for circulating free fatty acids? Diabetes $47,1693-1698$

53. Samec S, Seydoux J, and Dulloo AG (1998). Role of UCP homologues in skeletal muscles and brown adipose tissue: mediators of thermogenesis or regulators of lipids as fuel substrate? FASEB / 12, 715-724

54. Samec S, Seydoux J, and Dulloo AG (1999). Post-starvation gene expression of skeletal muscle uncoupling protein 2 and uncoupling protein 3 in response to dietary fat levels and fatty acid composition. A link with insulin resistance. Diabetes 48, 436-441

55. Sanchis D, Fleury $C$, Chomiki $N$, Goubern $M$, Huang $Q$, Neverova $M$, Gregoire F, Easlick J, Raimbault S, Lévi-Meyrueis C, Miroux B, Collins S, Seldin M, Richard D, Warden C, Bouillaud $F$, and Ricquier D (1998). BMCP1, a novel mitochondrial carrier with high expression in the central nervous system of humans and rodents, and respiration uncoupling activity in recombinant yeast. I Biol Chem 273, 34611-34615

56. Santalucia T, Camps M, Castello A, Munoz P, Nuel A, Testar X, Palacin M, and Zorzano A (1992). Developmental regulation of GLUT-1 (erythroid/Hep G2) and GLUT-4 (muscle/fat) glucose transporter expression in rat heart, skeletal muscle, and brown adipose tissue. Endocrinology $130,837-846$

57. Schaap FG, van der Vusse G), and Glatz JF (1998). Fatty acid-binding proteins in the heart. Mol Cell Biochem 180, 43-51

58. Schaffer JE and Lodish HF (1994). Expression cloning and characterization of a novel adipocyte long chain fatty acid transport protein. Cell 79, 427-436

59. Schoonjans K, Staels B, and Auwerx J (1996). The peroxisome proliferator activated receptors (PPARs) and their effects on lipid metabolism and adipocyte differentiation. Biochim Biophys Acta 1302, 93-109

60. Shih HM and Towle HC (1992). Definition of the carbohydrate response element of the rat S14 gene. Evidence for a common factor required for carbohydrate regulation of hepatic genes. I Biol Chem 267, 13222-13228

61. Skulachev VP (1991). Fatty acid circuit as a physiological mechanism of uncoupling of oxidative phosphorylation. FEBS Lett 294, 158-162

62. Skulachev VP (1998). Uncoupling: new approaches to an old problem of bioenergetics. Biochim Biophys Acta 1363, 100-124

63. Storch $J$ and Thumser AE (2000). The fatty acid transport function of fatty acid-binding proteins. Biochim Biophys Acta 1486, 28-44

64. Stremmel W, Lotz G, Strohmeyer G, and Berk PD (1985). Identification, isolation, and partial characterization of a fatty acid binding protein from rat jejunal microvil tous membranes. $/ \mathrm{Clin}$ Invest 75, 1068-1076

65. Teboul L, Gaillard D, Staccini L, Inadera H, Amri E-Z, and Grimaldi PA (1995). Thiazolidinediones and fatty acids convert myogenic cells into adipose-like cells. I Biol Chem 270, 28183-28187

66. Turek Z and Rakušan K (1981). Lognormal distribution of intercapillary distance in normal and hypertrophic rat heart as estimated by the method of concentric circles: its effect on tissue oxygenation. Eur / Physiol 391, 17-21

67. Van Bilsen $M$ and Chien KR (1993). Growth and hypertrophy of the heart: towards an understanding of cardiac specific and inducible gene expression. Cardiovasc Res 27, 11401149

68. Van Bilsen M, de Vries JE, and van der Vusse Gl (1997). Long-term effects of fatty acids on cell viability and gene expression of neonatal cardiac myocytes. Prostaglandins Leukot Essent Fatty Acids 57, 30-45

69. Van der Vusse G), Glatz JFC, Stam HCG, and Reneman RS (1992). Fatty acid homeostasis in the normoxic and ischemic heart. Physiol Rev 72, 881-940

70. Van der Vusse GJ, van Bilsen $M$, and Glatz JFC (2000). Cardiac fatty acid uptake and transport in health and disease. Cardiovasc Res 45, 279-293 
71. Vidal-Puig A, Solanes G, Grujic D, Flier JS, and Lowell BB (1997). UCP3: An uncoupling protein homologue expressed preferentially and abundantly in skeletal muscle and brown adipose tissue. Biochem Biophys Res Commun 235, 79-82

72. Wang C and Hu SM (1991). Developmental regulation in the expression of rat heart glucose transporters. Biochem Biophys Res Commun 177, 1095-1100

73. Winkler $E$ and Klingenberg $M$ (1994). Effect of fatty acids on $\mathrm{H}^{+}$transport activity of the reconstituted uncoupling protein. / Biol Chem 269, 2508-2515

74. Yu XX, Mao W, Zhong A, Schow P, Brush J, Sherwood SW, Adams SH, and Pan G (2000). Characterization of novel UCP5/BMCP1 isoforms and differential regulation of UCP4 and UCP5 expression through dietary or temperature manipulation. FASEB / 14, 1611-1618

75. Zhang C-Y, Hagen T, Mootha VK, Slieker LJ, and Lowell BB (1999). Assessment of uncoupling activity of uncoupling protein 3 using a yeast heterologous expression system. FEBS Lett 449, 129-134

76. Zhang J and Lazar MA (2000). The mechanism of action of thyroid hormones. Annu Rev Physiol 62, 439-466

77. Zorzano A, Sevilla L, Camps M, Becker C, Meyer J, Kammermeier H, Munoz P, Guma A, Testar X, Palacin M, Blasi J, and Fischer $Y$ (1997). Regulation of glucose transport, and glucose transporters expression and trafficking in the heart: studies in cardiac myocytes. Am / Cardiol $80,65 \mathrm{~A}-76 \mathrm{~A}$ 


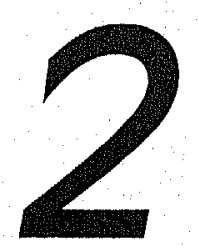

\section{Fatty acid-regulated gene expression in the heart: involvement of peroxisome proliferator-activated receptors}

Karin AJM van der Lee, Kristel FJ de Brouwer, Ger J van der Vusse, and Marc van Bilsen

Department of Physiology, Cardiovascular Research Institute Maastricht, Maastricht University, the Netherlands

Recent Res Devel Lipids 4, 25-38 (2000) 


\section{Abstract}

The utilisation of fatty acids as a fuel by the heart changes under different pathophysiological conditions. Evidence is accumulating that fatty acids themselves are able to modulate gene expression in cardiac muscle cells. The fatty acid-induced effects are likely to be mediated via the nuclear transcription factors peroxisome proliferator-activated receptors (PPARS). PPARS exert their function following interaction with cis-regulatory DNA sequences, referred to as peroxisome proliferatorresponsive elements (PPREs), which have been found in promoter regions of a large number of genes involved in lipid metabolism. By acting as ligands, fatty acids can activate PPARs. The activity of PPARs is in addition controlled by their phosphorylation status, by proteins acting as coactivators or corepressors, and by other members of the nuclear hormone family. A regulatory function of fatty acids and PPARs during alterations in cardiac metabolism associated with certain pathophysiological conditions should be considered.

\section{Introduction}

Circulating long-chain fatty acids are important substrates for overall energy metabolism in mammals. As for the cardiac muscle they are the prevailing source of energy under normal physiological conditions, their oxidation covering about $2 / 3$ of the energy demand of the heart [114]. In addition, they are part of phospholipids, the building blocks of cellular membranes. More recently, it is becoming increasingly clear that fatty acids are also able to affect the activity of certain proteins in various ways. Following covalent binding to proteins they are thought to target these proteins to cellular membranes [45]. Through non-covalent interaction, they have been shown to affect the activity of ion-channels, and various proteins involved in cellular signal transduction, among which protein kinase C (PKC) $[42,44,54,58]$. It has also become evident that fatty acids are able to interact with certain transcription factors, thereby directly affecting gene expression. By now there is substantial evidence to support the notion that fatty acids act as ligands for the so-called peroxisome proliferator-activated receptors (PPARs), transcription factors belonging to the family of nuclear hormone receptors. In this review we will discuss the biological significance of long-chain fatty acids as modulators of gene expression. Special emphasis will be placed on the potential role of PPARs as modulators of cardiac gene expression under normal and pathophysiological conditions, and factors in addition to fatty acids that may control PPAR activity. 


\section{Fatty acids alter cardiac gene expression}

A potential effect of long-chain fatty acids on gene expression was first recognised in studies on adipocyte differentiation. Fatty acids were shown to promote differentiation of fibroblast-like preadipocytes into adipocytes, along with an induction of the expression of certain differentiation markers [38]. Subsequent studies revealed that fatty acids also affect gene expression in hepatocytes [16,51,53]. This raised the question whether fatty acids exert similar effects on other parenchymal cells with high rates of fatty acid metabolism, among which cardiac and skeletal myocytes.

As far as the cardiac muscle is concerned, a relationship between plasma fatty acid levels and cardiac fatty acid utilisation had already been noted. An elevation of plasma fatty acid levels, as occurs during perinatal development, fasting and diabetes, coincided with an increased cardiac fatty acid utilisation [32-34,69,70,76]. Theoretically, the increased uptake and metabolism of fatty acids could be simply due to the rise in plasma substrate concentration. However, there are clear indications that in addition to enhanced supply, the cardiac muscle also adapts by adjusting the tissue content of proteins involved in fatty acid uptake and the activity of enzymes involved in fatty acid oxidation $[115,118]$. Recent findings indicate that such adjustments are accomplished, at least in part, by altering the rates of gene transcription $[82,115,118]$.

Since fatty acids are known to alter the expression of certain genes in adipocytes and hepatocytes, it is tempting to speculate that the increased levels of blood-borne fatty acids are directly responsible for the alterations in cardiac gene expression. However, the rise in fatty acid levels is not the only change that occurs after birth and as a result of fasting and diabetes. Plasma levels of insulin, glucagon, and thyroid hormone, which are all implicated in the regulation of fatty acid metabolism, alter as well. Therefore, the involvement of other factors in adjusting cardiac gene expression should be considered under these conditions.

The use of cellular systems as experimental models can eliminate much of the confounding factors that are inherent to the use of in vivo models. Hence, to assess whether fatty acids per se are able to alter cardiac gene expression we have cultured neonatal rat ventricular myocytes in defined medium containing different substrates $[111,112]$. After a pre-incubation on serum-free medium containing glucose as the sole substrate, cells were exposed to glucose, fatty acids (palmitic and oleic acid), or a combination of both substrates. After two days of incubation in the presence of fatty acids, the capacity of the neonatal cardiomyocytes to oxidise fatty acids had increased significantly [112]. Northern blot analysis revealed that fatty acids induced 2 to 4 fold increases in the mRNA levels of proteins involved in fatty acid uptake and intracellular transport, i.e. fatty acid translocase (FAT/CD36) and heart-type fatty acidbinding protein (H-FABP), and those involved in fatty acid metabolism, i.e. acyl-CoA synthetase (ACS), muscle-type carnitine palmitoyl transferase-1 (mCPT1) and longchain acyl-CoA dehydrogenase (LCAD) (Fig. 2.1). At the same time, mRNA levels of structural proteins were not affected and the expression of proteins involved in glucose metabolism, including the glucose transporter GLUT4 and hexokinase II, decreased to some extent. Using the same protocol, it was demonstrated that fatty acids were also able to alter metabolic gene expression in a cell line derived from 


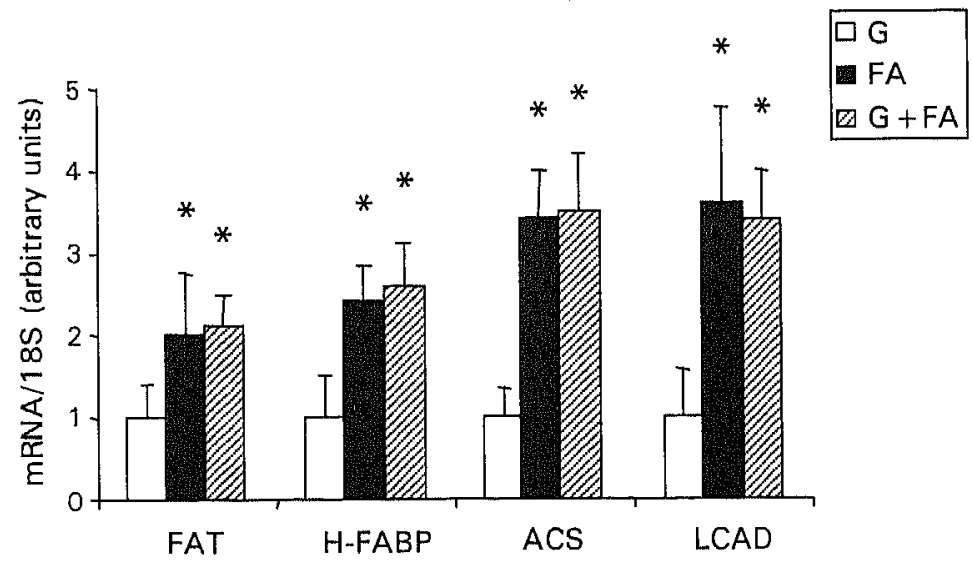

Figure 2.1 Fatty acids increase the expression of fatty acid translocase/CD36 (FAT), heart-type fatty acid-binding protein (H-FABP), acyl-COA synthetase (ACS), and long-chain acyl-CoA dehydrogenase (LCAD). Neonatal rat cardiomyocytes were cultured in the presence of glucose $(10 \mathrm{mM}$; G), fatty acids (palmitic and oleic acid $250 \mu \mathrm{M}$ each; $\mathrm{FA}$ ), or a combination of both (G +FA) for $48 \mathrm{~h}$. mRNA levels were normalised to the corresponding $18 \mathrm{~S}$ signals. The level of expression of the control group (G) was arbitrarily set at 1.0. Data are presented as means \pm SD. * indicates $p<0.05$ versus glucose group.

embryonic rat heart tissue, $\mathrm{H} 9 \mathrm{c} 2$ [113]. Taken together these findings point to a selective upregulation of the expression of genes specifically involved in cardiac fatty acid utilisation.

The ability of fatty acids to alter cardiac gene expression in an isolated cell system may infer that also under in vivo conditions fatty acids modulate the expression of proteins involved in fatty acid transport and metabolism. The exact mechanisms underlying the fatty acid-induced changes in cardiac gene expression are, however, incompletely understood. In the following paragraphs the potential role of PPARs in this process will be discussed.

\section{PPARs as mediators of fatty acid-induced gene expression}

In 1990, Issemann and Green [46] reported the discovery of the mouse peroxisome proliferator-activated receptor (PPAR). PPAR is a ligand-activated transcription factor and was then demonstrated to bind so-called peroxisome proliferators, synthetic compounds including hypolipidaemic drugs, herbicides, and industrial plasticisers. As the name implies, peroxisome proliferators stimulate the proliferation of hepatic peroxisomes and peroxisomal $\beta$-oxidation. Since the discovery of the first PPAR, which was later referred to as PPAR $\alpha$, other PPAR subtypes have been described in different species and tissues. At present three PPARs have been identified: PPAR $\alpha$, PPAR $\beta / \delta$ (also called NUC- 1 or FAAR) and PPAR $\gamma[3,5,17,22,35,36,94,102,105,122]$. The three PPAR subtypes are each encoded by different genes. For PPAR $\gamma$ two 
different splice variants have been cloned, PPAR 1 and PPAR $\gamma 2$, which differ at their $\mathrm{NH}_{2}$ terminus [23,36]. PPARs have been described to be involved in lipid metabolism, adipogenesis, inflammation, atherosclerosis, and carcinogenesis (see $[28,30,37,116]$ for recent reviews).

The tissue distribution varies among the PPAR subtypes. PPAR $\alpha$ is mainly expressed in liver, kidney, heart and intestine. PPAR $\beta / \delta$ is expressed in a wide range of tissues, including heart, kidney, brain, lung, intestine, spleen, and skeletal muscle. PPAR 1 is abundantly present in adrenal gland, spleen, intestine, and kidney, whereas PPAR 2 is primarily expressed in adipose tissue. The presence of PPAR $y$ in the heart is questionable and may be species dependent. Whereas PPARy mRNA has been detected in hearts of mice and hamster $[5,59,129]$, PPAR $\gamma$ mRNA and protein could not be detected in the rat heart using in situ hybridisation and immunohistochemistry, respectively [11]. Also the northern blot technique failed in detecting PPARy in the adult rat heart and in neonatal rat cardiomyocytes (E.M. Gelissen and K.A.J.M. van der Lee, unpublished observations). So, if present at all, the levels of PPAR $\gamma$ in cardiac muscle cells are likely to be low. Nevertheless, the presence of PPAR $\alpha$ and PPAR $\beta / \delta$ in the heart indicates that PPAR-mediated transcriptional regulation is likely to play a role in this organ.

\section{PPARs are nuclear hormone receptors that recognise PPREs}

PPARs belong to the family of nuclear hormone receptors and are closely related to the thyroid hormone receptor (TR), all-trans retinoic acid receptor (RAR) and vitamin $D$ receptor (VDR). Independent of ligand binding, these related receptors are localised in the cellular nucleus. Nuclear hormone receptors share a close structural homology, which consists of several structural and functional domains (Fig. 2.2) [108]. The Nterminal $A / B$ domain is least conserved and includes a ligand-independent transactivation function (AF-1), containing putative phosphorylation sites. The DNAbinding $C$ domain is best conserved and includes two zinc finger motifs, which contain two conserved boxes. The P-box determines contact with specific DNA sequences (also called responsive elements) and the D-box is involved in receptor dimerisation. The variable hinge region (D domain) allows the protein to alter its

$D B D$

\begin{tabular}{|l|l|l|l|l|}
\hline$A / B$ & $C$ & $D$ & $E$ & $F$ \\
\hline
\end{tabular}

$[\mathrm{AF}-1]$
$[\mathrm{AF}-2]$

Figure 2.2 Schematic representation of the nuclear hormone receptor domain structure. The $N$ terminal $A / B$ domain contains a ligand-independent transactivation function (AF-1). The $C$ domain is the DNA-binding domain (DBD) consisting of two zinc fingers. The hinge region (D domain) allows the receptor to change conformation. The $\mathrm{E}$ domain is the ligand-binding domain (LBD) and includes a ligand-dependent transactivation function (AF-2). The function of the C-terminal F domain is unknown. 
conformation. The ligand-binding domain ( $E$ domain) encompasses a liganddependent transactivation function (AF-2). In addition to ligand binding, the $\mathrm{E}$ domain is required for nuclear localisation and receptor dimerisation and is able to interact with cofactors, proteins involved in activation or repression of nuclear hormone receptor activity (see below). At this moment, no specific function has been described for the $\mathrm{C}$-terminal $\mathrm{F}$ domain.

To exert its function, PPAR forms a heterodimer with the retinoid-X-receptor (RXR), which uses 9-cis-retinoic acid as a ligand $[29,56,62]$. The heterodimer subsequently interacts with a DNA sequence called peroxisome proliferator-responsive element (PPRE) (Fig. 2.3). A PPRE is a direct repeat separated by one spacer nucleotide (DR-1) and has the consensus sequence AGGTCA $n$ AGCTCA. Functional PPREs, demonstrated to induce expression of a reporter gene in transfection assays, have been found in a number of genes encoding proteins mainly involved in lipid metabolism, among which apolipoprotein A-II, ACS, the peroxisomal enzyme acylCoA oxidase, the microsomal enzyme cytochrome P-450 w-hydroxylase, the fatty acid transporters FAT/CD36, fatty acid transport protein (FATP) and liver-type FABP, and the mitochondrial enzymes $\mathrm{mCPT} 1$ and medium chain acyl-CoA dehydrogenase (MCAD) $[27,39,73,80,86,97,106,109,117]$. Thus, PPARs may mediate alterations in the expression of genes involved in systemic and cellular fatty acid transport and metabolism.

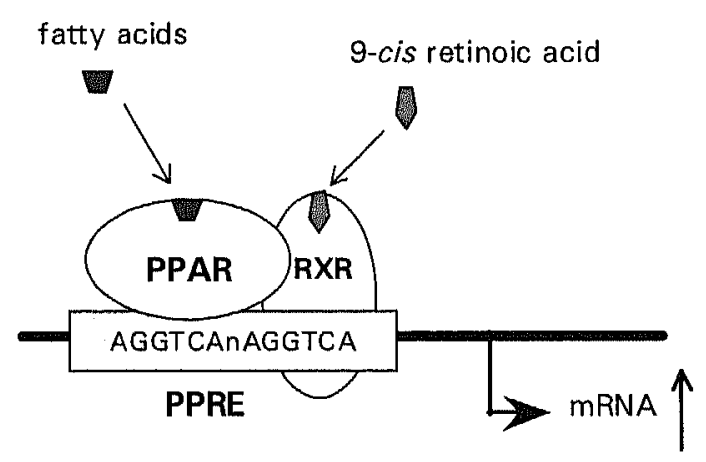

Figure 2.3 Simplified figure depicting the interaction between the peroxisome proliferatoractivated receptor (PPAR), the retinoid-X-receptor ( $R X R)$ and the peroxisome proliferator-responsive element (PPRE).

\section{Nature of PPAR ligands}

Although PPARs have been named for their ability to be activated by peroxisome proliferators, only the PPAR $\alpha$ subtype is genuinely effective in interacting with these compounds. Fibrates, like fenofibrate and clofibrate, are a class of hypolipidaemic drugs and potent PPAR $\alpha$ activators. In addition to these synthetic compounds, the arachidonic acid derivative $8(\mathrm{~S})$-hydroxyeicosatetraenoic acid (8(S)-HETE) as well as other eicosanoids have been demonstrated to be effective natural ligands for PPAR $\alpha$ 
[125]. Antidiabetic thiazolidinediones are specific synthetic activators for PPAR $\gamma$, whereas 15-deoxy- $\triangle 12,14$-prostaglandin J2 (PGJ2) has been identified as a natural ligand for this receptor $[26,60]$. A specific synthetic ligand for PPAR $\beta / \delta$, the phenoxyacetic acid derivative L-165041, has been described recently [7]. A strong natural PPAR $\beta / \delta$ ligand has not been found so far, although it has been suggested that the very long-chain fatty acid erucic acid is a specific PPAR $\beta / \delta$ activator [48]. However, this notion has been challenged by recent observations that erucic acid was not able to compete with radioligands for binding to the PPAR $\beta / \delta$ ligand binding domain [123].

In addition to synthetic compounds and arachidonic acid metabolites, long-chain fatty acids have been shown to bind and activate all three PPAR subtypes $[25,35,47,48,61]$. In Xenopus, fatty acids do not have a preference for either PPAR $\alpha$ or PPARY [61], whereas in mammalian species fatty acids have been demonstrated to interact with PPAR $\alpha$ and PPAR $\beta / \delta$ but hardly with PPAR $\gamma[25,48]$. Various groups have attempted to estimate the dissociation constants of fatty acids for PPARs. However the results so far are not unequivocal as values in the micromolar $[61,63,81,123]$ and nanomolar [68] range have both been reported. In general, the PPAR binding affinity was found to be higher for poly- and monounsaturated fatty acids than for saturated fatty acids. The dissociation constants of fatty acids for PPARs are obviously of significance to establish whether fatty acids are indeed natural ligands for PPARs. In this respect it is also noteworthy that the actual intracellular fatty acid level is still subject of discussion. The total concentration of the cytoplasmic pool of unesterified fatty acids in cardiomyocytes has been estimated to have an upper limit of $10 \mu M$ [114]. Less is, however, known about the concentration and availability of fatty acids within the nuclear compartment. Since the majority of the poorly water-soluble fatty acids is bound to cytoplasmic fatty acid-binding proteins or intercalated in cellular membranes [114], the actual free fatty acid concentration is likely to be much lower. Accordingly, dissociation constants of fatty acids to PPAR should be in the submicromolar range in order to be effective as natural ligands. Conversely, it has been hypothesised that transfer of fatty acids to PPAR in the nucleus may be facilitated by the intracellular fatty acid transporter FABP, since H-FABP is present, albeit in low amounts, in nuclei of cardiomyocytes [10] and the liver-type FABP is able to interact with PPAR $\alpha$ [121].

To test whether PPARs may indeed be involved in cardiac gene expression, specific ligands for PPAR $\alpha$ and PPAR $\gamma$ were added to the medium of cultured neonatal rat cardiomyocytes [1 12]. In the presence of the PPAR $\alpha$ specific ligand $W y-14,643$ the expression of genes encoding H-FABP, ACS and LCAD increased markedly (Fig. 2.4). The PPAR $\gamma$ specific ligand ciglitazone did not affect the expression of the genes tested, indicating that PPAR $\gamma$ probably does not play a significant role in cardiomyocytes. The data demonstrate that a functional PPAR $\alpha$ is present in the neonatal cardiomyocytes. This, together with the notion that fatty acids may act as ligands for PPARs, indicates that PPAR $\alpha$ may mediate the fatty acid-induced changes in cardiac metabolic gene expression. However, a role for PPAR $\beta / \delta$ or any other mechanism cannot be excluded. 


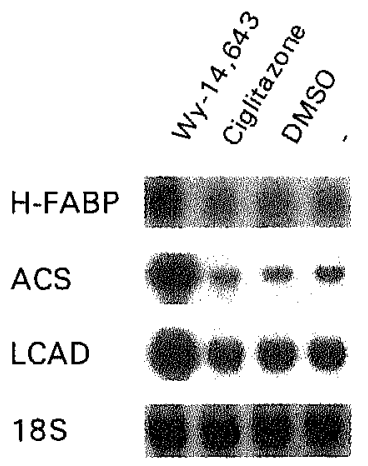

Figure 2.4 mRNA expression of heart-type fatty acid-binding protein ( $H-F A B P$ ), acyl-CoA synthetase (ACS), and long-chain acyl-COA dehydrogenase (LCAD) is increased in the presence of a PPAR $\alpha$ specific ligand ( $W y-14,643)$, but not by a PPAR $\gamma$ specific ligand (ciglitazone). Neonatal rat

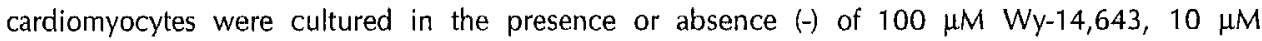
ciglitazone, or vehicle (DMSO) for $48 \mathrm{~h}$.

\section{PPARs are phosphorylated via MAP kinases}

The presence of a consensus mitogen-activated protein (MAP) kinase phosphorylation site at a serine residue in the ligand-independent transactivation function (AF-1) of PPARy, urged several groups to investigate whether PPARs are phosphoproteins. Indeed, PPAR $\gamma$ has been demonstrated to be a target of MAP kinases. Overexpression of PPAR $\gamma$ and a constitutively active MAP kinase in Chinese hamster ovary $(\mathrm{CHO})$ cells increased the fraction of phosphorylated PPAR $\gamma$, whereas overexpression of a dominant negative MAP kinase had opposite effects [128]. MAP kinases, localised both in the cytoplasm and in the nucleus, form a family of Ser/Thr kinases and can be divided in extracellular signal-regulated kinases (ERK1/2), Jun $\mathrm{NH}_{2}$-terminal kinase (JNK)/stress-activated protein kinase (SAPK) and p38 kinases [24,99]. PPAR $\gamma$ has been demonstrated to be phosphorylated by ERK $1 / 2$ and JNK/SAPK, but not by p38 kinases $[1,14]$. At this moment, it is unclear whether other protein kinases are also able to phosphorylate PPAR $\gamma$.

Recent findings strongly suggest that the C-terminal ligand-binding domain and the $\mathrm{N}$-terminal region of PPARy communicate, thereby regulating the activity of the transcription factor [13,101]. Ligand binding reduces the ability of PPAR $y$ to become phosphorylated [13]. Conversely, phosphorylation of PPAR $\gamma$ reduces the affinity of the receptor to bind its ligand, thereby inhibiting PPARY activity [101]. Evidence is accumulating that phosphorylation modifies the tertiary structure of PPAR $\gamma$ and, hence, decreases the ability of the protein to convert into the liganded conformation [101]. It is of interest to note that instead of loss of activity of PPAR $\gamma$ upon phosphorylation [1,13,43], Zhang et al. [128] provided evidence that insulinstimulated phosphorylation of PPAR $\gamma$ results in increased transcriptional activity. At present no satisfying explanation can be provided for the observed discrepancies concerning the effect of phosphorylation on the transcriptional activity of PPAR $\gamma$. 
Besides PPAR $\gamma$, PPAR $\alpha$ has also been shown to be phosphorylated in a MAP kinase dependent manner [50]. In contrast, phosphorylation of PPAR $\beta / \delta$ does not seem to occur [13]. PPAR $\alpha$ contains three putative MAP kinase phosphorylation sites in the AF-1 region, two of which have been shown to be functional [50]. Phosphorylation of PPAR $\alpha$ was found to promote transcriptional activity $[50,100]$. In addition to insulin, ciprofibrate and $W y-14,643$, both peroxisome proliferators and ligands for PPAR $\alpha$, were able to increase phosphorylation of PPAR $\alpha$ in liver-derived rat Fao cells [85]. The mechanism by which these peroxisome proliferators evoke PPAR $\alpha$ phosphorylation is unknown. The question whether phosphorylation of PPAR $\alpha$, either through ligand dependent or independent mechanisms, affects cardiac gene expression needs to be clarified.

\section{PPARs interact with coactivators and corepressors}

A variety of proteins, termed cofactors, has been shown to interact physically with transcription factors of the nuclear hormone receptor family, among which PPARs, and to modulate transcriptional activity of these receptors (see review [74] and references therein). Depending on their ability to stimulate or inhibit receptor activity, these proteins are called coactivators or corepressors, respectively. As a working hypothesis it has been postulated that corepressors bind to nuclear receptors in the absence of ligand, thereby preventing transcriptional activity. In the presence of ligand, the three-dimensional structure of the receptor alters and, consequently, corepressors are released and coactivators recruited, resulting in increased gene transcription. Coactivators and corepressors are thought to modulate transcriptional activity by interacting both with nuclear receptors and basal transcription factors, thereby affecting the rate of assembly of the basal transcription initiation complex [74]. Furthermore, some cofactors can alter the accessibility of genes through acetylation/deacetylation of histones, the basic protein units of nucleosomes. Acetylation of histone tails reduces their positive charge and hence promotes the dissociation from the negatively charged DNA helix [74].

The majority of coactivators and corepressors described so far interacts with various nuclear hormone receptors, and thus shows limited specificity. Coactivators known to interact with PPARs include the steroid receptor coactivator SRC-1, the PPAR binding protein (PBP), the PPAR gamma coactivators PGC-1 and PGC-2, and the integrator protein $p 300[15,18,31,87,130,131]$. These proteins have all been shown to be expressed in cardiac muscle $[15,87,126,130]$. Interestingly, PPAR $\alpha$ function was demonstrated to be intact in SCR-1 knockout mice, suggesting that redundancy in coactivators exists [88]. Corepressors for PPARs have been described as well. They include the receptor-interacting protein-140 (RIP-140) $[78,107,124]$, the silencing mediator of retinoid and thyroid receptors (SMRT) $[64,89,124,127]$, and the nuclear receptor corepressor (NCoR) [21]. For some of these proteins there are indications that they display some sort of selectivity regarding the PPAR subtype. For instance, PGC-2 has been demonstrated to bind PPAR $\gamma$, but not PPAR $\alpha$ or PPAR $\beta / \delta$ [15]. NCoR did not affect PPAR $\gamma$ activity, but repressed PPAR $\alpha$ activity $[21,64,127]$. 
As the majority of coactivators and corepressors was discovered only recently, many questions regarding their biological function await to be answered. It is important to note that most of these proteins were discovered on the basis of the yeast two-hybrid assay. For many of these cofactors it remains to be established whether they actually play a role in mammalian cell physiology as regulators of PPAR activity. Furthermore, it is not clear if their interaction with PPARs depends on ligand binding, heterodimerisation with RXR, and PPAR phosphorylation status. Observations so far indicate that each of these processes is likely to affect transcriptional activation or repression of PPARs to a large extent $[30,50,64,98,101]$.

\section{PPARs and other nuclear receptors}

As stated above, many nuclear hormone receptors require $R X R$ as a dimerisation partner. As a consequence, competition for this heterodimerisation partner may occur. Indeed, PPAR was shown to decrease the activity of TR by sequestration of RXR $[9,49,75]$. Vice versa, PPAR activity was found to decrease when cells were cotransfected with the thyroid hormone receptor or several other nuclear receptors, including chicken ovalbumin upstream promoter transcription factor COUP-TF, the hepatocyte nuclear factor HNF-4, TAK-1, and RevErbo $[55,71,77,79,119,120,124]$. As indicated above, sequestration of RXR by these nuclear receptors may be the cause of PPAR inhibition. Moreover, these nuclear receptors were demonstrated to interact with PPREs and competition for a specific PPRE may subsequently decrease PPAR activity. Finally, certain nuclear hormone receptors may interact with PPAR, resulting in a non-functional heterodimer. Indeed, for rat, but not for human, it has been demonstrated that PPAR $\alpha$ is able to bind TR $[9,49]$. Thus, promiscuous dimerisation and occupation of PPRE by other nuclear hormone receptors may limit the effects of PPAR on its target genes. Since nuclear hormone receptor activity is modulated by cofactors, competition for this group of proteins may play a role as well.

Taken together, these data illustrate the complexity of mechanisms regulating the transactivation function of PPARs. The presence or absence of ligands, dimerisation partners, responsive elements, cofactors, and the degree of phosphorylation, all play a role.

\section{Fatty acids, PPARs and cardiac pathophysiology}

The relative abundance of PPAR $\alpha$ and PPAR $\beta / \delta$ in the heart, strongly suggests that these transcription factors are involved in the regulation of cardiac gene expression. Indeed, in contrast to a PPAR $\gamma$ specific ligand, addition of a PPAR $\alpha$ specific ligand to cultured rat neonatal cardiomyocytes resulted in a marked induction of H-FABP, ACS and LCAD expression (Fig. 2.4).

Extrapolation of findings of in vitro experimental models to the in vivo situation should however be done with caution. For instance, whereas ACS expression substantially increased in cultured neonatal cardiomyocytes in the presence of a PPAR $\alpha$ specific ligand, cardiac ACS expression remained unaffected when PPAR $\alpha$ 
ligands (fibrates) were administered to adult rats $[72,96]$. Also during fasting, when circulating fatty acid levels are increased and cardiac fatty acid utilisation is enhanced, the expression of ACS did not change in the adult heart $[82,118]$. At this moment it is not clear whether the differences observed can be attributed to culture conditions or are related to developmental changes. It is tempting to speculate that the availability of cofactors and/or the phosphorylation status of PPAR $\alpha$ are subject to developmental regulation.

Interestingly, while treatment of rats with fibrates did not affect cardiac mRNA levels of proteins involved in lipid metabolism, including lipoprotein lipase, FATP and ACS $[72,95,96]$, treatment of mice with the CPT1 inhibitor etomoxir resulted in an approximately two-fold increase in mRNA levels of mCPT1, LCAD, MCAD and acylCoA oxidase $[12,20]$. In addition to species differences, the use of different PPAR $\alpha$ activators may explain the inconsistency with respect to changes in genes encoding fatty acid converting enzymes. Whereas fibrates act as genuine ligands for PPAR $\alpha$, the exact mechanism of action of the CPT1 inhibitor etomoxir remains to be established [41]. Finally, it should be noted that in the above mentioned studies different genes involved in fatty acid handling were studied.

The availability of PPAR $\alpha$ deficient mice has provided additional insights in the involvement of PPAR $\alpha$ in cardiac gene expression. PPAR $\alpha(-/)$ mice have already been demonstrated to be resistant to effects of peroxisome proliferators, as the expression of PPAR target genes in liver, like acyl-CoA oxidase, cytochrome P-450 $\omega$ hydroxylase, liver-type FABP, ACS, and LCAD could not be enhanced $[4,65]$. With respect to cardiac gene expression, Kelly and co-workers $[12,19,20]$ showed that mRNA expression levels of $\mathrm{mCPT1}, \mathrm{LCAD}, \mathrm{MCAD}$ and acyl-CoA oxidase were lower in hearts of PPAR $\alpha(-/)$ mice than in wild-type animals. Moreover, treatment with the CPT1 inhibitor etomoxir did not affect cardiac mCPT1, MCAD, or acyl-CoA oxidase gene expression in PPAR $\alpha$ deficient mice $[12,20]$. Furthermore, in contrast to wildtype mice, fasting of PPAR $\alpha(-/)$ mice did not increase the expression of mCPT1, MCAD, or acyl-COA oxidase in the heart [66]. The latter findings provide compelling evidence for the regulatory role of PPAR $\alpha$ in the expression of genes encoding proteins involved in cardiac fatty acid metabolism. Additionally, the results imply that PPAR $\beta / \delta$ is not able to compensate for the lack of the $\alpha$-isoform, indicating that $\operatorname{PPAR} \beta / \delta$ and $\mathrm{PPAR} \alpha$ have distinct functions.

As indicated earlier, fasting and diabetes are conditions in which the heart is even more dependent on the use of fatty acids as an energy source [32,69]. Both conditions are accompanied by an increased expression of genes coding for proteins involved in fatty acid transport and metabolism in the heart $[82,115,118]$. Conversely, during cardiac diseases like hypertrophy and failure the utilisation of fatty acids as an energy source decreases $[2,52]$. This is associated with a substantial downregulation of genes involved in fatty acid metabolism, including FAT/CD36, H-FABP, mCPT1 and LCAD [90-92] (K.F.J. de Brouwer and M. van Bilsen, unpublished observations). Interestingly, expression of the PPAR $\alpha$ protein was shown to be decreased in hypertrophied hearts of pulmonary aorta-banded mice, whereas the nuclear receptor COUP-TF, which is able to compete for PPREs, increased [91]. The latter observation suggests that the 
reduced utilisation of fatty acids by the hypertrophied heart could be related to changes in nuclear PPAR $\alpha$ levels, and other transcription factors competing for PPRE.

It is worth to note that patients with genetic defects in fatty acid oxidation enzymes may suffer from cardiomyopathies [57]. In addition, the incidence of a deficiency in FAT/CD36 was found to be high in patients with hypertrophic cardiomyopathy and was therefore suggested to be a cause for this cardiac disorder $[84,104]$. This has recently been disputed by others who did not notice statistical differences between patients with normal or deficient FAT/CD36 expression with respect to their clinical data [83]. On the other hand, mice lacking FAT/CD36 display dilated cardiomyopathy [40]. Likewise, cardiac hypertrophy develops in H-FABP (-/) mice at advanced age [8]. Together, these findings indicate that a decline in cardiac fatty acid uptake and metabolism may contribute to cardiac pathophysiology.

\section{Future perspectives}

This review focuses on the effects of fatty acids on the expression of genes involved in fatty acid metabolism in the heart with special emphasis on the role of PPARs herein. A potential role of fatty acids in modulating the expression of genes involved in the metabolism of alternative fuels for the myocardium, such as glucose, certainly deserves attention. While fatty acids can increase the expression of fatty acid metabolic genes, they were found to decrease the mRNA levels of genes encoding proteins involved in glucose metabolism, including the glucose transporter GLUT4 and hexokinase II in neonatal cardiomyocytes $[111,112]$. Whether these effects of fatty acids are mediated via PPARs is uncertain, since genuine PPAR $\alpha$ ligands, like Wy14,643 , were not able to decrease GLUT4 expression in neonatal cardiomyocytes [112].

The effects of fatty acids on genes coding for proteins not involved in cardiac metabolism should be considered as well. Roles for PPAR $\beta / \delta$ and PPAR $\gamma$ in embryo implantation and embryonic (heart) development, respectively, have been described $[6,67]$. Experiments of Safonova and colleagues [93] are also worth to mention. They demonstrated that fatty acids in differentiating adipocytes were able to induce the expression of angiotensinogen, whose product, angiotensin $\mathrm{Il}$, has an essential function in cardiovascular adaptation [110]. In addition, fatty acids were shown to induce the expression of RXR $\alpha$ in cultured hepatocytes [103]. The use of microarrays, which involves screening of a known set of mRNAs, and differential display-like techniques, which may retrieve unknown gene transcripts as well, may help in achieving more insight in this matter.

To date, evidence is accumulating that PPARs can be considered as transcription factors mediating fatty acid-induced changes in gene expression in the heart. Certainly, fatty acids may be involved in other signalling pathways as well. The search for factors other than PPARs mediating fatty acid-induced changes in cardiac gene expression will be a challenge for future research. 


\section{Acknowledgements}

M. van Bilsen is an established investigator of the Netherlands Heart Foundation (D98.015).

\section{References}

1. Adams $M$, Reginato MJ, Shao D, Lazar MA, and Chatterjee VK (1997). Transcriptional activation by peroxisome proliferator-activated receptor $\gamma$ is inhibited by phosphorylation at a consensus mitogen-activated protein kinase site. / Biol Chem 272, 5128-5132

2. Allard MF, Schönekess BO, Henning SL, English DR, and Lopaschuk GD (1994). Contribution of oxidative metabolism and glycolysis to ATP production in hypertrophied hearts. Am I Physiol 267, H742-H750

3. Amri E-Z, Bonino F, Ailhaud G, Abumrad NA, and Grimaldi PA (1995). Cloning of a protein that mediates transcriptional effects of fatty acids in preadipocytes. Homology to peroxisome proliferator-activated receptors. J Biol Chem 270, 2367-2371

4. Aoyama T, Peters JM, Iritani N, Nakajima T, Furihata K, Hashimoto T, and Gonzalez FJ (1998). Altered constitutive expression of fatty acid-metabolizing enzymes in mice lacking the peroxisome proliferator-activated receptor $\alpha$ (PPAR $\alpha$ ). I Biol Chem 273, 5678-5684

5. Aperlo C, Pognonec P, Saladin R, Auwerx J, and Boulukos KE (1995). cDNA cloning and characterization of the transcriptional activities of the hamster peroxisome proliferatoractivated receptor haPPAR $\gamma$. Gene 162, 297-302

6. Barak $Y$, Nelson MC, Ong ES, Jones $Y Z$, Ruiz-Lozano $P$, Chien KR, Koder $A$, and Evans RM (1999). PPAR $\gamma$ is required for placental, cardiac, and adipose tissue development. Mol Cell 4, 585-595

7. Berger J, Leibowitz MD, Doebber TW, Elbrecht A, Zhang B, Zhou G, Biswas C, Cullinan CA, Hayes NS, Li Y, Tanen M, Ventre J, Wu MS, Berger GD, Mosley R, Marquis R, Santini C, Sahoo SP, Tolman RL, Smith RG, and Moller DE (1999). Novel peroxisome proliferatoractivated receptor (PPAR) $\gamma$ and PPARS ligands produce distinct biological effects. I Biol Chem $274,6718-6725$

8. Binas B, Danneberg $H$, McWhir J, Mullins L, and Clark AJ (1999). Requirement for the hearttype fatty acid binding protein in cardiac fatty acid utilization. FASEB J 13, 805-812

9. Bogazzi F, Hudson LD, and Nikodem VM (1994). A novel heterodimerization partner for thyroid hormone receptor. Peroxisome proliferator-actviated receptor. I Biol Chem 269 , 11683-11686

10. Borchers T, Unterberg C, Rudel $H$, Robenek $H$, and Spener $F$ (1989). Subcellular distribution of cardiac fatty acid-binding protein in bovine heart muscle and quantitation with an enzymelinked immunosorbent assay. Biochim Biophys Acta 1002, 54-61

11. Braissant $O$, Foufelle $F$, Scotto $C$, Dauça $M$, and Wahli W (1996). Differential expression of peroxisome proliferator-activated receptors (PPARs): tissue distribution of PPAR- $\alpha,-\beta$, and $-\gamma$ in the adult rat. Endocrinology 137, 354-366

12. Brandt JM, Djouadi $r$, and Kelly DP (1998). Fatty acids activate transcription of the muscle carnitine palmitoyltransferase 1 gene in cardiac myocytes via the peroxisome proliferatoractivated receptor $\alpha$. J Biol Chem 273, 23786-23792

13. Camp HS and Tafuri SR (1997). Regulation of peroxisome proliferator-activated receptor $\gamma$ activity by mitogen-activated protein kinase. J Biol Chem 272, 10811-10816

14. Camp HS, Tafuri SR, and Leff T (1999). c-jun N-terminal kinase phosphorylates peroxisome proliferator-activated receptor- $\gamma 1$ and negatively regulates its transcriptional activity. Endocrinology 140, 392-397 
15. Castillo G, Brun RP, Rosenfield JK, Hauser S, Park CW, Troy AE, Wright ME, and Spiegelman $B M(1999)$. An adipogenic cofactor bound by the differentiation domain of PPAR . EMBO / $18,3676-3687$

16. Chatelain F, Kohl C, Esser V, McGarry JD, Girard J, and Pegorier J-P (1996). Cyclic AMP and fatty acids increase carnitine palmitoyltransferase $I$ gene transcription in cultured fetal rat hepatocytes. Eur / Biochem 235, 789-798

17. Chen F, Law SW, and O'Malley BW (1993). Identification of two mPPAR related receptors and evidence for the existence of five subfamily members. Biochem Biophys Res Commun 196, $671-677$

18. DiRenzo J, Söderström $M$, Kurokawa $R$, Ogliastro $M-H$, Ricote $M$, Ingrey $S$, Hörlein $A$, Rosenfeld MG, and Glass CK (1997). Peroxisome proliferator-activated receptors and retinoic acid receptors differentially control the interactions of retinoid $X$ receptor heterodimers with ligands, coactivators, and corepressors. Mol Cell Biol 17, 2166-2176

19. Djouadi F, Brandt JM, Weinheimer CJ, Leone TC, Gonzalez FJ, and Kelly DP (1999). The role of the peroxisome proliferator-activated receptor $\alpha(P P A R \alpha)$ in the control of cardiac lipid metabolism. Prostaglandins Leukot Essent Fatty Acids 60, 339-343

20. Djouadi F, Weinheimer Cl, Saffitz JE, Pitchford C, Bastin J, Gonzalez FJ, and Kelly DP (1998). A gender-related defect in lipid metabolism and glucose homeostasis in peroxisome proliferator-activated receptor $\alpha$-deficient mice. / Clin Invest 102, 1083-1091

21. Dowell P, Ishmael JE, Avram D, Peterson VJ, Nevrivy DJ, and Leid M (1999). Identification of nuclear receptor corepressor as a peroxisome proliferator-activated receptor $\alpha$ interacting protein. I Biol Chem 274, 15901-15907

22. Dreyer C, Krey G, Keller H, Givel F, Helftenbein G, and Wahli W (1992). Control of the peroxisomal $\beta$-oxidation pathway by a novel family of nuclear hormone receptors. Cell 68 , 879-887

23. Fajas L, Auboeuf $D$, Raspé $E$, Schoonjans $K$, Lefebvre $A-M$, Saladin R, Najib J, Laville $M$, Fruchart J-C, Deeb S, Vidal-Puig A, Flier J, Briggs MR, Staels B, Vidal H, and Auwerx J (1997). The organization, promoter analysis, and expression of the human PPARy gene. / Biol Chem $272,18779-18789$

24. Force T, Pombo CM, Avruch JA, Bonventre JV, and Kyriakis JM (1996). Stress-activated protein kinases in cardiovascular disease. Circ Res 78, 947-953

25. Forman BM, Chen ), and Evans RM (1997). Hypolipidemic drugs, polyunsaturated fatty acids, and eicosanoids are ligands for peroxisome proliferator-activated receptors $\alpha$ and $\delta$. Proc Natl Acad Sci USA 94, 4312-4317

26. Forman BM, Tontonoz P, Chen J, Brun RP, Spiegelman BM, and Evans RM (1995), 15-Deoxy$\Delta^{12,14}$-prostaglandin $\mathrm{J}_{2}$ is a ligand for the adipocyte determination factor PPAR $\gamma$. Cell 83, 803812

27. Frohnert BI, Hui $T Y$, and Bernlohr DA (1999). Identification of a functional peroxisome proliferator-responsive element in the murine fatty acid transport protein gene. / Biol Chem 272, 3970-3977

28. Fruchart $\}-C$, Duriez $P$, and Staels B (1999). Peroxisome proliferator-activated receptor-alpha activators regulate genes governing lipoprotein metabolism, vascular inflammation and atherosclerosis. Curr Opin Lipidol 10, 245-257

29. Gearing KL, Göttlicher M, Teboul M, Widmark E, and Gustafsson J-Å (1993). Interaction of the peroxisome-proliferator-activated receptor and retinoid $X$ receptor. Proc Nati Acad Sci USA 90, 1440-1444

30. Gelman L, Fruchart J-C, and Auwerx J (1999). An update on the mechanisms of action of the peroxisome proliferator-activated receptors (PPARs) and their roles in inflammation and cancer. Cell Mol Life Sci 55, 932-943

31. Gelman L, Zhou G, Fajas L, Raspé E, Fruchart J-C, and Auwerx J (1999). p300 interacts with the $\mathrm{N}$ - and $\mathrm{C}$-terminal part of PPAR 2 in a ligand-independent and -dependent manner, respectively. / Biol Chem 274, 7681-7688 
32. Ghezzi $C$, Dubois F, Mathieu JP, Cand F, Comet $M$, and Cuchet $P$ (1990). Effect of short-term fasting on [123l] iodohexadecenoic acid metabolism in the isolated perfused rat heart. Validation of mathematical model by comparison with experimental measurements. Arch int Physiol Biochim 98, 269-281

33. Girard J, Ferré P, Pégorier J-P, and Duée P.H (1992). Adaptations of glucose and fatty acid metabolism during perinatal period and suckling-weaning transition. Physiol Rev 72, 507-562

34. Glatz JFC and Veerkamp JH (1982). Postnatal development of palmitate oxidation and mitochondrial enzyme activities in rat cardiac and skeletal muscle. Biochim Biophys Acta $711,327-335$

35. Göttlicher M, Widmark E, Li Q, and Gustafsson J- $\AA$ (1992). Fatty acids activate a chimera of the clofibric acid-activated receptor and the glucocorticoid receptor. Proc Natl Acad Sci USA $89,4653-4657$

36. Greene ME, Blumberg B, MCBride OW, Yi HF, Kronquist K, Kwan K, Hsieh L, Greene $G$, and Nimer SD (1995). Isolation of the human peroxisome proliferator activated receptor gamma CDNA: expression in hematopoietic cells and chromosomal mapping. Gene Expr 4, 281-299

37. Grimaldi PA (1999). Roles of lipid-activated receptors in the adipogenic action of fatty acids. Lipids 34, S205-\$208

38. Grimaldi PA, Knobel SM, Whitesell RR, and Abumrad NA (1992). Induction of aP2 gene expression by nonmetabolized long-chain fatty acids. Proc Natl Acad Sci USA 89, 1093010934

39. Gulick T, Cresci S, Caira T, Moore DD, and Kelly DP (1994). The peroxisome proliferatoractivated receptor regulates mitochondrial fatty acid oxidative enzyme gene expression. Proc Natl Acad Sci USA 91, 11012-11026

40. Hahn RT, Febbraio M, Bella JN, and Silverstein RL. (1998). The role of CD36 in cardiac size and function: a possible murine model of dilated cardiomyopathy. Abstract. Circulation 98, I236

41. Hegardt FG, Serra D, and Asins G (1995). Influence of etomoxir on the expression of several genes in liver, testis and heart. Gen Pharmac 26, 897-904

42. Honore E, Barhanin J, Attali B, Lesage F, and Lazdunski M (1994). External blockade of the major cardiac delayed-rectifier $\mathrm{K}^{+}$channel (Kv1.5) by polyunsaturated fatty acids. Proc NaUl Acad Sci USA 91, 1937-1941

43. Hu E, Kim JB, Sarraf $P$, and Spiegelman BM (1996). Inhibition of adipogenesis through MAP kinase-mediated phosphorylation of PPAR $\gamma$. Science 274, 2100-2103

44. Huang JM, Xian $H$, and Bacaner $M$ (1992). Long-chain fatty acids activate calcium channels in ventricular myocytes. Proc Natl Acad Sci USA 89, 6452-6456

45. liri T, Backlund PS, Jr., Jones TL, Wedegaertner PB, and Bourne HR (1996). Reciprocal regulation of $\mathrm{G}_{i_{\alpha}}$ by palmitate and the $\beta \gamma$ subunit. Proc Natl Acad Sci USA 93, 14592-14597

46. Issemann I and Green S (1990). Activation of a member of the steroid hormone receptor superfamily by peroxisome proliferators. Nature $347,645-650$

47. Issemann I, Prince RA, Tugwood JD, and Green S (1993). The peroxisome proliferatoractivated receptor:retinoid $X$ receptor heterodimer is activated by fatty acids and fibrate hypolipidaemic drugs. / Mol Endocrinol 11, 37-47

48. Johnson TE, Holloway MK, Vogel R, Rutledge SJ, Perkins J\}, Rodan GA, and Schmidt A (1997). Structural requirements and cell-type specificity for ligand activation of peroxisome proliferator-activated receptors. / Steroid Biochem Molec Biol 63, 1-8

49. Juge-Aubry CE, Gorla-Bajszczak A, Pernin A, Lemberger $T$, Wahli W, Burger $A G$, and Meier CA (1995). Peroxisome proliferator-activated receptor mediates cross-talk with thyroid hormone receptor by competition for retinoid $X$ receptor. Possible role of a leuzine zipper-like heptad repeat. / Biol Chem 270, 18117-18122

50. Juge-Aubry CE, Hammar E, Siegrist-Kaiser C, Pernin A, Takeshita A, Chin WW, Burger AG, and Meier CA (1999). Regulation of the transcriptional activity of the peroxisome proliferatoractivated receptor $\alpha$ by phosphorylation of a ligand-independent trans-activating domain. I Biol Chem 274, 10505-10510 
51. Jump $D B$, Clarke SD, Thelen $A$, and Liimatta $M$ (1994). Coordinate regulation of glycolytic and lipogenic gene expression by polyunsaturated fatty acids. J Lipid Res 35, 1076-1084

52. Kagaya $Y$, Kanno $Y$, Takeyama D, Ishide N, Maruyama $Y$, Takahashi T, Ido T, and Takishima $T$ (1990). Effects of long-term pressure overload on regional myocardial glucose and free fatty acid uptake in rats. A quantitative autoradiographic study. Circulation 81, 1353-1361

53. Kaikaus RM, Sui Z, Lysenko N, Wu NY, Ortiz de Montellano PR, Ockner RK, and Bass NM (1993). Regulation of pathways of extramitochondrial fatty acid oxidation and liver fatty acidbinding protein by long-chain monocarboxylic fatty acids in hepatocytes. Effect of inhibition of carnitine palmitoyltransferase I. / Biol Chem 268, 26866-26871

54. Kang JX and Leaf $A$ (1996). Evidence that free polyunsaturated fatty acids modify $\mathrm{Na}^{+}$channels by directly binding to the channel proteins. Proc Natl Acad Sci USA 93, 3542-3546

55. Kassam A, Capone JP, and Rachubinski RA (1999). Orphan nuclear homone receptor RevErb $\alpha$ modulates expression from the promoter of the hydratase-dehydrogenase gene by inhibiting peroxisome prolierator-activated receptor $\alpha$-dependent transactivation. J Biol Chem 274, 22895-22900

56. Keller H, Dreyer C, Medin J, Mahfoudi A, Ozato K, and Wahli W (1993). Fatty acids and retinoids control lipid metabolism through activation of peroxisome proliferator-activated receptor-retinoid X receptor heterodimers. Proc Natl Acad Sci USA 90, 2160-2164

57. Kelly DP and Strauss AW (1994). Inherited cardiomyopathies. New Engl / Med 330, 913-919

58. Khan WA, Blobe GC, and Hannun YA (1995). Arachidonic acid and free fatty acids as second messengers and the role of protein kinase $C$. Cell Signal 7, 171-184

59. Kliewer SA, Forman BM, Blumberg B, Ong ES, Borgmeyer U, Mangelsdorf DJ, Umesono K, and Evans RM (1994). Differential expression and activation of a family of murine peroxisome proliferator-activated receptors. Proc Natl Acad Sci USA 97, 7355-7359

60. Kliewer 5A, Lenhard JM, Willson TM, Patel I, Morris DC, and Lehmann JM (1995). A prostaglandin $\mathrm{J}_{2}$ metabolite binds peroxisome proliferator-activated receptor $\gamma$ and promotes adipocyte differentiation. Cell 83, 813-819

61. Kliewer SA, Sundseth SS, Jones SA, Brown PJ, Wisely GB, Koble CS, Devchand P, Wahli W, Willson TM, Lenhard JM, and Lehmann JM (1997). Fatty acids and eicosanoids regulate gene expression through direct interactions with peroxisome proliferator-activated receptors $\alpha$ and \%. Proc Natl Acad Sci USA 94, 4318-4323

62. Kliewer SA, Umesono K, Noonan DJ, Heyman RA, and Evans RM (1992). Convergence of 9cis retinoic acid and peroxisome proliferator signalling pathways through heterodimer formation of their receptors. Nature 358, 771-774

63. Krey G, Braissant O, L-Horset F, Kalkhoven E, Perroud M, Parker MG, and Wahli W (1997). Fatty acids, eicosanoids, and hypolipidemic agents identified as ligands of peroxisome proliferator-activated receptors by coactivator-dependent receptor ligand assay. Mol Endocrinol 11, 779-791

64. Lavinsky RM, Jepsen K, Heinzel T, Torchia J, Mullen T-M, Schiff R, Del-Rio AL, Ricote M, Ngo S, Gemsch J, Hisenbeck SG, Osborne CK, Glass CK, Rosenfeld MG, and Rose DW (1998). Diverse signaling pathways modulate nuclear receptor recruitment of $\mathrm{N}$-COR and SMRT complexes. Proc Natl Acad Sci USA 95, 2920-2925

65. Lee SS-T, Pineau T, Drago J, Lee EJ, Owens JW, Kroetz DL, Fernandez-Salguero PM, Westphal $H$, and Gonzalez FJ (1995). Targeted disruption of the $\alpha$ isoform of the peroxisome proliferator-activated receptor gene in mice results in abolishment of the pleiotropic effects of peroxisome proliferators. Mol Cell Biol 15, 3012-3022

66. Leone TC, Weinheimer C), and Kelly DP (1999). A critical role for the peroxisome proliferatoractivated receptor $\alpha(P P A R \alpha)$ in the cellular fasting response: The PPAR $\alpha$-null mouse as a model of fatty acid oxidation disorders. Proc Nat/ Acad Sci USA 96, 7473-7478

67. Lim H, Gupta RA, Ma W-g, Paria BC, Moller DE, Morrow JD, DuBois RN, Trzaskos JM, and Dey SK (1999). Cyclo-oxygenase-2-derived prostacyclin mediates embryo implantation in the mouse via PPARS. Genes Dev 13, 1561-1574 
68. Lin Q, Ruuska SE, Shaw NS, Dong D, and Noy N (1999). Ligand selectivity of the peroxisome proliferator-activated receptor $\alpha$. Biochemistry $38,185-190$

69. Lopaschuk GD (1992). Fatty acid metabolism in the heart following diabetes. In The heart in diabetes. Chatham JC, Forder JR, and $\mathrm{MCNeill} \mathrm{JH,} \mathrm{Eds.} \mathrm{Kluwer} \mathrm{Academic} \mathrm{Publishers,} \mathrm{Boston,}$ 215-251

70. Lopaschuk GD, Collins-Nakai RL, and Itoi $T$ (1992). Developmental changes in energy substrate use by the heart. Cardiovasc Res 26, 1172-1180

71. Marcus SL, Capone JP, and Rachubinski RA (1996), Identification of COUP-TFII as a peroxisome proliferator response element binding factor using genetic selcetion in yeast: COUP-TFIl activates transcription in yeast but anatogonizes PPAR signaling in mammalian cells. Mol Cell Endocrinol 120, 31-39

72. Martin G, Schoonjans K, Lefebvre A-M, Staels B, and Auwerx ) (1997). Coordinate regulation of the expression of the fatty acid transport protein and acyl-CoA synthetase genes by PPAR $\alpha$ and PPAR $\gamma$ activators. J Biol Chem 272, 28210-28217

73. Mascaró C, Acosta E, Ortiz JA, Marrero PF, Hegardt FG, and Haro D (1998). Control of human muscle-type carnitine palmitoyltransferase I gene transcription by peroxisome proliferatoractivated receptor. J Biol Chem 273, 8560-8563

74. McKenna N\}, Lanz RB, and O'Malley BW (1999). Nuclear receptor coregulators: cellutar and molecular biology. Endocr Rev 20, 321-344

75. Meier-Heusler SC, Zhu X, Juge-Aubry C, Pernin A, Burger AG, Cheng S-y, and Meier CA (1995). Modulation of thyroid hormone action by mutant thyroid hormone receptors, $c$ erbA 22 and peroxisome proliferator-activated receptor: evidence for different mechanisms of inhibition. Mol Cell Endocrinol 107, 55-66

76. Menahan LA and Sobocinski KA (1983). Comparison of carbohydrate and lipid metabolism in mice and rats during fasting. Comp Biochem Physiol 74B, 859-864

77. Miyamoto T, Kaneko A, Kakizawa T, Yajima H, Kamijo K, Sekine R, Hiramatsu K, Nishii Y, Hashimoto $T$, and Hashizume $K$ (1997). Inhibition of peroxisome protiferator signaling pathways by thyroid hormone receptor. Competitive binding to the response element. / Biol Chem 272, 7752-7758

78. Miyata KS, McCaw SE, Meertens LM, Patel HV, Rachubinski RA, and Capone JP (1998). Receptor-interacting protein 140 interacts with and inhibits transactivation by, peroxisome proliferator-activated receptor $\alpha$ and liver-X-receptor $\alpha$. Mol Cell Endocrinol 146, 69-76

79. Miyata KS, Zhang B, Marcus SL, Capone JP, and Rachubinski RA (1993). Chicken ovalbumin upstream promoter transcription factor (COUP-TF) binds to a peroxisome proliferator responsive element and antagonizes peroxisome proliferator-mediated sigaling. / Biol Chem 268, 19169-19172

80. Muerhoff AS, Griffin KJ, and Johnson EF (1992). The peroxisome proliferator-activated receptor mediates the induction of CYP4AG, a cytochrome P450 fatty acid $\omega$-hydroxylase, by clofibric acid. J Biol Chem 267, 19051-19053

81. Murakami K, Ide T, Suzuki M, Mochizuki T, and Kadowaki T (1999). Evidence for direct binding of fatty acids and eicosanoids to human peroxisome proliferators-activated receptor $\alpha$. Biochem Biophys Res Commun 260, 609-613

82. Nagao M, Parimoo B, and Tanaka K (1993). Developmental, nutritional, and hormonal regulation of tissue-specific expression of the genes encoding various acyl-CoA dehydrogenases and $\alpha$-subunit of electron transfer flavoprotein in rat. / Biol Chem 268, 2411424124

83. Nakamura $T$, Sugihara $H$, Inaba $T$, Kinoshita $N$, Adachi $Y$, Hirasaki $S$, Matsuo A, Azuma A, and Nakagawa $M$ (1999). CD36 deficiency has little influence on the pathophysiology of hypertrophic cardiomyopathy. I Mol Cell Cardiol 31, 1253-1259

84. Okamoto F, Tanaka T, Sohmiya K, and Kawamura K (1998). CD36 abnormality and impaired myocardial long-chain fatty acid uptake in patients with hypertrophic cardiomyopathy. Ipn Circ / 62, 499-504 
85. Passilly P, Schohn H, Jannin B, Malki MC, Boscoboinik D, Dauça M, and Latruffe N (1999). Phosphorylation of peroxisome proliferator-activated receptor $\alpha$ in rat Fao cells and stimulation by ciprofibrate. Biochem Pharmacol 58, 1001-1008

86. Poirier $H$, Braissant $O$, Niot I, Wahli W, and Besnard $P$ (1997). 9-cis-Retinoic acid enhances fatty acid-induced expression of the liver fatty acid-binding protein gene. FEBS Lett 412, 480484

87. Puigserver $P, W u Z$, Park CW, Graves R, Wright $M$, and Spiegelman BM (1998). A coldinducible coactivator of nuclear receptors linked to adaptive thermogenesis. Cell 92, 829-839

88. Qi C, Zhu Y, Pan J, Yeldandi AV, Rao MS, Maeda N, Subbarao V, Pulikuri S, Hashimoto T, and Reddy JK (1999). Mouse steroid receptor coactivator-1 is not essential for peroxisome proliferator-activated receptor $\alpha$-regulated gene expression. Proc Natl Acad Sci USA 96, 15851590

89. Robinson CE, Wu X, Nawaz Z, Oñate SA, and Gimble JM (1999). A corepressor and chicken ovalbumin upstream promoter transcriptional factor proteins modulate peroxisome proliferator-activated receptor- $\gamma_{2} /$ retinoid $X$ receptor $\alpha$-activated transcription from the murine lipoprotein lipase promoter. Endocrinology 140, 1586-1593

90. Rosenblatt-Velin N, Papageorgiou I, Terrand J, and Lerch R (1999). Myocardial remodeling: regional differences in the expression of regulatory proteins of metabolism. Abstract. / Mol Cell Cardiol 31, A76

91. Sack MN, Disch DL, Rockman HA, and Kelly DP (1997). A role for Sp and nuclear receptor transcription factors in a cardiac hypertrophic growth program. Proc Natl Acad Sci USA 94, 6438-6443

92. Sack MN, Rader TA, Park S, Bastin J, McCune SA, and Kelly DP (1996). Fatty acid oxidation enzyme gene expression is downregulated in the failing heart. Circulation 94, 2837-2842

93. Safonova I, Aubert J, Negrel R, and Ailhaud G (1997). Regulation by fatty acids of angiotensinogen gene expression in preadipose cells. Biochem /322, 235-239

94. Schmidt A, Endo N, Rutledge SI, Vogel R, Shinar D, and Rodan GA (1992). Identification of a new member of the steroid hormone receptor superfamily that is actviated by a peroxisome proliferator and fatty acids. Mol Endocrinol 6, 1634-1641

95. Schoonjans K, Peinado-Onsurbe J, Lefebvre A-M, Heyman RA, Briggs $M$, Deeb S, Staels B, and Auwerx J (1996). PPAR $\alpha$ and PPAR $\gamma$ activators direct a distinct tissue-specific transcriptional response via a PPRE in the lipoprotein lipase gene. EMBO / 15, 5336-5348

96. Schoonjans K, Staels B, Grimaldi P, and Auwerx J (1993). Acyl-CoA synthetase mRNA expression is controlled by fibric-acid derivatives, feeding and liver proliferation. Eur I Biochem 216, 615-622

97. Schoonjans K, Watanabe $M$, Suzuki $H$, Mahfoudi A, Krey G, Wahli W, Grimaldi P, Staels B, Yamamoto T, and Auwerx J (1995). Induction of the acyl-Coenzyme A synthetase gene by fibrates and fatty acids is mediated by a peroxisome proliferator response element in the $C$ promoter. / Biol Chem 270, 19269-19276

98. Schulman IG, Shao $G$, and Heyman RA (1998). Transactivation by retinoid $X$ receptorperoxisome proliferator-activated receptor $\gamma$ (PPAR $\gamma$ ) heterodimers: intermolecular synergy requires only the PPAR $\gamma$ hormone-dependent activation function. Mol Cell Biol 18, 3483-3494

99. Seger $R$ and Krebs EG (1995). The MAPK signaling cascade. FASEB / 9, 726-735

100. Shatev A, Siegrist-Kaiser CA, Yen PM, Wahli W, Burger AG, Chin WW, and Meier CA (1996). The peroxisome proliferator-activated receptor $\alpha$ is a phosphoprotein: regulation by insulin. Endocrinology 137, 4499-4502

101. Shao D, Rangwala SM, Bailey ST, Krakow SL, Reginato MJ, and Lazar MA (1998). Interdomain communication regulating ligand binding by PPAR- $\gamma$. Nature 396, 377-380

102. Sher T, Yi HF, McBride OW, and Gonzalez FJ (1993). cDNA cloning, chromosomal mapping, and functional characterization of the human peroxisome proliferator actvited receptor. Biochemistry 32, 5598-5604 
103. Steineger $H H$, Arntsen BM, Spydevold $O$, and Sarensen HN (1997). Retinoid $X$ receptor $(R X R \alpha)$ gene expression is regulated by fatty acids and dexamethasone in hepatic cells. Biochimie 79, 107-110

104. Tanaka T, Sohmiya K, and Kawamura K (1997). Is CD36 deficiency an etiology of hereditary hypertrophic cardiomyopathy? / Mol Cell Cardiol 29, 121-127

105. Tontonoz P, Hu E, Graves RA, Budavari Al, and Spiegelman BM (1994). mPPAR $\gamma 2$ : tissuespecific regulator of an adipocyte enhancer. Genes Dev 8, 1224-1234

106. Tontonoz P, Nagy L, Alvarez JGA, Thomazy VA, and Evans RM (1998). PPAR $\gamma$ promotes monocyte/macrophage differentiation and uptake of oxidized LDL. Cell 93, 241-252

107. Treuter $E$, Albrektsen T, Johansson L, Leers $\rfloor$, and Gustafsson $I \AA$ (1998). A regulatory role for RIP140 in nuclear receptor activation. Mol Endocrinol 12, 864-881

108. Tsai MJ and O'Malley BW (1994). Molecular mechanisms of action of steroid/thyroid receptor superfamily members. Annu Rev Biochem 63, 451-486

109. Tugwood JD, Issemann I, Anderson RG, Bundell KR, MCPheat WL, and Green S (1992). The mouse peroxisome proliferator activated receptor recognizes a response element in the $5^{\prime}$ flanking sequence of the rat acyl CoA oxidase gene. EMBO/11,433-439

110. Van Bilsen $M$ (1997). Signal transduction revisited: recent developments in angiotensin II signaling in the cardiovascular system. Cardiovasc Res 36, 310-322

111. Van Bilsen M, van der Lee KAJM, and van der Vusse GJ (1999). Long-chain fatty acids and signal transduction in the cardiac muscle cell. In Cardiovascular specific gene expression. Doevendans PA, Reneman RS, and van Bilsen M, Eds. Kluwer Academic Publishers, Dordrecht, the Netherlands, 257-268

112. Van der Lee KAJM, Vork MM, de Vries JE, Willemsen PHM, Glatz JFC, Reneman RS, van der Vusse GJ, and van Bilsen $M(2000)$. Long-chain fatty acid-induced changes in gene expression in neonatal cardiac myocytes. / Lipid Res 41, 41-47

113. Van der Lee KAJM, Willemsen PHM, val der Vusse G\}, and van Bilsen M (1999). Modulation of gene expression by fatty acids in non-differentiated and differentiated cardiac-derived $\mathrm{H} 9 \mathrm{c} 2$ cells. Abstract. / Mol Cell Cardiol 31, A69

114. Van der Vusse GJ, Glatz JFC, Stam HCG, and Reneman RS (1992). Fatty acid homeostasis in the normoxic and ischemic heart. Physiol Rev 72,881-940

115. Van Nieuwenhoven FA, Willemsen PHM, van der Vusse GJ, and Glatz JFC (1999). Coexpression in rat heart and skeletal muscle of four genes coding for proteins implicated in long-chain fatty acid uptake. Int / Biochem Cell Biol 31, 489-498

116. Vanden Heuvel JP (1999). Peroxisome proliferator-activated receptors: A critical link among fatty acids, gene expression and carcinogenesis. I Nutr 129, 5755-580S

117. Vu Dac N, Schoonjans K, Kosykh V, Dallongeville J, Fruchart JC, Staels B, and Auwerx J (1995). Fibrates increase human apolipoprotein A-ll expression through activation of the peroxisome proliferator-activated receptor. / Clin Invest 96, 741-750

118. Willemsen PHM, van der Lee KAJM, van der Vusse G], Samec S, and van Bilsen $M(1999)$. Fasting affects metabolic gene expression in the rat heart. Abstract. / Mol Cell Cardiol 31, A89

119. Winrow CJ, Kassam A, Miyata KS, Marcus SL, Hunter J, Capone JP, and Rachubinski RA (1996). Interplay of the peroxisome proliferator-activated receptor and the thyroid hormone receptor-signaling pathways in regulating peroxisome proliferator-responsive genes. Ann NY Acad Sci 804, 214-230

120. Winrow CJ, Marcus SL, Miyata KS, Zhang B, Capone JP, and Rachubinski RA (1994). Transactivation of the peroxisome proliferator-activated receptor is differentially modulated by hepatocyte nuclear factor-4. Cene Expr 4, 53-62

121. Wolfrum C, Borrmann CM, Franke WW, Gorski J, and Spener $F$ (1999). Fatty acids and drugs interacting with FABP and PPAR in hepatocytes - a signaling path to the nucleus. Abstract. Chem Phys Lipids 101, 149 
122. Xing G, Zhang L, Zhang L, Heynen T, Yoshikawa T, Smith M, Weiss S, and Detera-Wadleigh S (1995). Rat PPAR $\delta$ contains a CGG triplet repeat and is prominently expressed in the thalamic nuclei. Biochem Biophys Res Commun 217, 1015-1025

123. $\mathrm{Xu} \mathrm{HE}$, Lambert $M H$, Montana VG, Parks DJ, Blanchard SG, Brown PJ, Sternbach DD, Lehmann JM, Wisely GB, Willson TM, Kliewer SA, and Milburn MV (1999). Molecular recognition of fatty acids by peroxisome proliferator-activated receptors. Mol Cell 3, 397-403

124. Yan ZH, Karam WG, Staudinger JL, Medvedev A, Ghanayem BI, and Jetten AM (1998). Regulation of peroxisome proliferator-activated receptor $\alpha$-induced transactivation by the nuclear orphan receptor TAK1/TR4. / Biol Chem 273, 10948-10957

125. Yu K, Bayona W, Kallen CB, Harding HP, Ravera CP, MCMahon G, Brown M, and Lazar MA (1995). Differential activation of peroxisome proliferator-activated receptors by eicosanoids. I Biol Chem 270, 23957-23983

126. Yuan C-X, Ito M, Fondell JD, Fu Z-Y, and Roeder RG (1998). The TRAP220 component of a thyroid hormone receptor-associated protein (TRAP) coactivator complex interacts directly with nuclear receptors in a ligand-dependent fashion. Proc Natl Acad Sci USA 95, 7939-7944

127. Zamir I, Zhang J, and Lazar MA (1997). Stoichiometric and steric principles governing repression by nuclear hormone receptors. Cenes Dev 11, 835-846

128. Zhang B, Berger J, Zhou G, Elbrecht A, Biswas S, White-Carrington S, Szalkowski D, and Moller DE (1996). Insulin- and mitogen-activated protein kinase-mediated phosphorylation and activation of peroxisome proliferator-activated receptor $\gamma$. I Biol Chem 271, 31771-31774

129. Zhu Y, Alvares K, Huang Q, Rao MS, and Reddy JK (1993). Cloning of a new member of the peroxisome proliferator-activated receptor gene family from mouse liver. / Biol Chem 268, 26817-26820

130. Zhu Y, Qi C, Calandra C, Rao MS, and Reddy JK (1996). Cloning and identification of mouse steroid receptor coactivator-1 (mSRC-1), as a coactivator of peroxisome proliferator-activated receptor $\gamma$. Gene Expr 6, 185-195

131. Zhu Y, Qi C, Jain S, Rao MS, and Reddy JK (1997). Isolation and characterization of PBP, a protein that interacts with peroxisome proliferator-activated receptor. / Biol Chem 272, 25500. 25506 


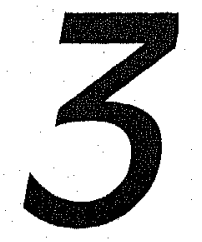

\section{Long-chain fatty acid-induced changes in gene expression in neonatal cardiac myocytes}

Karin AJM van der Lee, Michaël M Vork, Johan E de Vries, Peter HM Willemsen, Jan FC Glatz, Robert S Reneman, Ger J van der Vusse, and Marc van Bilsen

Department of Physiology, Cardiovascular Research Institute Maastricht, Maastricht University, the Netherlands

J Lipid Res, 41, 41-47 (2000) 


\section{Abstract}

Long-chain fatty acids are the most important substrates for the heart. In addition, they have been shown to affect signalling pathways and gene expression. To explore the effects of long-chain fatty acids on cardiac gene expression neonatal rat ventricular myocytes were cultured for 48 hours with glucose $(10 \mathrm{mM})$, fatty acids (palmitic and oleic acid, $0.25 \mathrm{mM}$ each), or a combination of both as exogenous substrates. Exposure to fatty acids (both in the absence or presence of g/ucose) neither affected cellular morphology and protein content, nor induced alterations in the expression of phenotypic marker genes like atrial natriuretic factor and the Ca-ATPase SERCA2. However, incubation with fatty acids (with or without glucose) resulted in up to 4-fold increases of the mRNA levels of fatty acid translocase (FAT/CD36), hearttype fatty acid-binding protein, acyl-CoA synthetase and long-chain acyl-CoA dehydrogenase. In contrast, the expression of genes coding for proteins involved in glucose uptake and metabolism, i.e. glucose transporter GLUT4, hexokinase II and glyceraldehyde 3-phosphate dehydrogenase, remained constant or even declined under these conditions. These changes corresponded with a $60 \%$ increase in cardiomyocyte fatty acid oxidation capacity. Interestingly, exposure to the peroxisome proliferator-activated receptor- $\alpha$ (PPAR $\alpha$ )-ligand $W y-14,643$, but not the PPAR $\alpha$ ligand ciglitazone, also resulted in increased mRNA levels of genes involved in fatty acid metabolism. In conclusion, fatty acids specifically and co-ordinately upregulate transcription of genes coding for proteins involved in cardiac fatty acid transport and metabolism, most likely through activation of PPAR $\alpha$.

\section{Introduction}

Cardiac function is dependent on a continuous supply of such nutrients, as long-chain fatty acids and glucose [33]. Recent findings indicate that, in addition to being an important energy source, fatty acids are also involved in signal transduction pathways in various tissues, including the heart [31]. In preadipocytes exposure to long-chain fatty acids was found to markedly affect gene expression and differentiation [5,12]. Likewise, the administration of fatty acids to $\mathrm{C} 2 \mathrm{C} 12 \mathrm{~N}$ skeletal myoblasts inhibited their differentiation into myotubes and actually induced the expression of adipocytespecific genes, like aP2, the adipocyte lipid-binding protein [29].

As for now the effects of fatty acids on gene expression in the cardiac myocyte are only beginning to be appreciated. In a preliminary study we showed that in neonatal cardiac myocytes fatty acids are able to increase the mRNA level of heart-type fatty acid-binding protein (H-FABP) [30]. Using the same model system, it was demonstrated recently that fatty acids enhanced the transcriptional activity of the muscle-type carnitine palmitoyl transferase 1 (mCPT1) gene [6]. These observations prompted us to investigate in more detail the effects of long-chain fatty acids on 
cardiomyocyte phenotype in general and on the expression of genes encoding proteins involved in glucose and fatty acid metabolism in particular. Primary cultures of neonatal rat ventricular cardiomyocytes were chosen as model system, as the supply of substrates can be easily manipulated [7]. In the present study the cardiomyocytes were incubated in minimal medium to which either glucose, fatty acids (palmitic acid and oleic acid complexed to albumin), or a combination of glucose and fatty acids had been added. The effects of these substrates on cellular phenotype were assessed cytochemically, by measuring cellular protein content, and through monitoring the expression of phenotypic markers, like atrial natriuretic factor (ANF) and cardiac sarcoplasmic reticulum $\mathrm{Ca}^{2+}$-ATPase (SERCA2). The effects of substrate supply on the mRNA levels of a range of proteins involved in glucose handling, i.e. glucose transporter 4 (GLUT4), hexokinase II (HKII) and glyceraldehyde 3-phosphate dehydrogenase (GAPDH), and various stages of fatty acid uptake and metabolism, i.e. fatty acid translocase (FAT/CD36), cardiac fatty acid-binding protein (H-FABP), acyl-COA synthetase (ACS) and long chain acyl-CoA dehydrogenase (LCAD), were evaluated. Because mRNA levels of proteins related to fatty acid uptake and metabolism were found to be upregulated following exposure to fatty acids, the functional consequence of this upregulation for the cellular capacity to oxidise fatty acids was also investigated. Finally, as fatty acids have been implicated as natural ligands for transcription factors of the family of peroxisome proliferator-activated receptors (PPARs) $[11,17]$, the effects of specific PPAR-ligands were evaluated.

\section{Materials and methods}

\section{Cell culture}

Primary cultures of neonatal rat ventricular myocytes were prepared as described previously [7]. Experiments were approved by the Institutional Animal Care and User Committee of the Maastricht University. Cardiomyocytes were plated at low density (250 cells $/ \mathrm{mm}^{2}$ ) in tissue culture dishes coated with $1 \%$ gelatine type B (G-9382, Sigma, St. Louis MO, USA) in a 4:1 mixture of DMEM (Gibco-42430, Gibco-BRL. Life Technologies, Gaithersburg MD, USA) and M199 (Gibco-31153) supplemented with $10 \%$ horse serum (Gibco-16050), 5\% newborn calf serum (Sera-Lab, Sussex, UK), and antibiotics (P/S; penicillin $100 \mathrm{lU} / \mathrm{ml}$ and streptomycin $0.1 \mathrm{mg} / \mathrm{ml}$, Gibco). Overnight incubation in serum-rich medium was followed by $24 \mathrm{~h}$ incubation in serum-free medium of a 4:1 mixture of DMEM/M199, containing P/S and $10 \mathrm{mM}$ glucose as the sole substrate. Subsequently, the myocytes were rinsed once with substrate-free medium (4:1 mixture of DMEM (Gibco-11963) and glucose-free M199 (Gibco31153)), to which L-carnitine $(0.25 \mathrm{mM})$, insulin $(0.25 \mathrm{mU} / \mathrm{ml})$ and bovine serum albumin (BSA $0.15 \mathrm{mM}$; Sigma A-7906) had been added. This medium was supplemented with different (combinations of) substrates. The first experimental group received only glucose (final concentration $10 \mathrm{mM}$ ) as substrate. The second group received a mixture of palmitic acid (C16:0) and oleic acid (C18:1) $(0.25 \mathrm{mM}$ each; complexed to $0.15 \mathrm{mM}$ BSA as described elsewhere [7]). The third group received a 
combination of both substrates, i.e. glucose $(10 \mathrm{mM})$ and $\mathrm{C} 16: 0 / \mathrm{C} 18: 1(0.25 \mathrm{mM}$ each). Following $48 \mathrm{~h}$ of incubation cardiomyocytes were either harvested for RNA isolation, used for cytochemical staining, or for measuring the rate of fatty acid oxidation.

In a separate series of experiments cells receiving only glucose $(10 \mathrm{mM})$ as

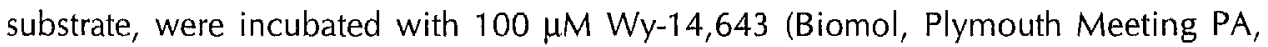
USA) or $10 \mu \mathrm{M}$ ciglitazone (Biomol), specific ligands for PPAR $\alpha$ and PPAR $\gamma$, respectively. Stock solutions of $W y-14,643$ and ciglitazone were prepared in DMSO. After $48 \mathrm{~h}$ of incubation cardiomyocytes were harvested for RNA isolation.

\section{Analysis of mRNA expression}

Total RNA was isolated with TRlzol reagent (GIBCO). RNA $(5 \mu \mathrm{g})$ was size-fractionated on a denaturating gel ( $1 \%$ agarose, $6.6 \%$ formaldehyde, $1 \times$ MOPS), transferred to a nylon membrane (Hybond-N, Amersham, Slough, UK) by capillary transfer, and fixed using standard techniques. Following prehybridisation the filters were probed with a $1600 \mathrm{bp} \mathrm{Xbal-Xhol} \mathrm{fragment} \mathrm{of} \mathrm{rat} \mathrm{GLUT4} \mathrm{CDNA} \mathrm{(a} \mathrm{gift} \mathrm{from} \mathrm{Dr.} \mathrm{D.}$ James, University of Queensland, Australia), a 1390 bp EcoRI fragment of rat LCAD (a gift from Dr. K. Tanaka, Yale University, USA), a 2500 bp EcoRl fragment of rat FAT/CD36 (kindly provided by Dr. N.A. Abumrad, State University New York, USA), a $676 \mathrm{bp} \mathrm{EcoRI-BamHI} \mathrm{fragment} \mathrm{of} \mathrm{H-FABP,} \mathrm{a} 700 \mathrm{bp} \mathrm{HindIII-BamHI} \mathrm{fragment} \mathrm{of} \mathrm{ANF}$ (gift from Dr. K. Chien, University of California San Diego, USA), a 320 bp Nsil-EcoRI fragment of SERCA2 (a gift from Dr. W. Simonides, Free University Amsterdam, The Netherlands), a 520 bp EcoRV-HindIII fragment of ACS (gift from Dr. T. Yamamoto, Tohoku University, Sendai, Japan), a 3200 bp EcoRI-Kpnl fragment from HKII (gift from Dr. E. Wilson, Michigan State University, USA) and a 1400 bp EcoRI-HindlII fragment from GAPDH. The cDNA probes were labelled with $\left[\alpha{ }^{32} \mathrm{P}\right] \mathrm{dCTP}(3000$ $\mathrm{Ci} / \mathrm{mmol}$; Amersham) by random-priming (Radprime, Life Technologies) to a specific activity of $>0.5 \times 10^{9} \mathrm{cpm} / \mu \mathrm{g}$ DNA. To correct for possible differences in transfer and loading the filters were also hybridised with a ${ }^{32}$ P-labelled ribosomal $18 \mathrm{~S}$ probe. Following hybridisation filters were washed at the appropriate stringency to remove non-specific binding. The filters were exposed to phosphor imaging screens and subsequently scanned with a Phosphor-Imager (Molecular Dynamics, Sunnyvale CA, USA), and quantified using ImageQuant software (Molecular Dynamics).

\section{Cytochemistry}

Following fixation of the cells in alcoholic formalin $(90 \%$ ethanol, $4 \%$ formalin in doubly distilled $\mathrm{H}_{2} \mathrm{O}$ ) at room temperature for $1 \mathrm{~min}$, glycogen was visualised by periodic acid-Schiff (PAS) staining [23]. Neutral lipids (triacylglycerols) were visualised with Oil Red-O (Aldrich Chemical Company, Milwaukee WI, USA) as described elsewhere [7]. PAS- and Oil Red-O-stained cells were counterstained with haematoxylin (Sigma GHS-2-16). 


\section{Fatty acid oxidation}

In a subset of experiments fatty acid oxidation capacity was determined of cardiomyocytes following $48 \mathrm{~h}$ of incubation in the presence of the different substrates. Oxidation experiments were performed as modified from Luiken et al. [19], using a buffer solution containing (in mM), HEPES (20), $\mathrm{NaH}_{2} \mathrm{PO}_{4}(1), \mathrm{MgSO}_{4}(0.4)$, $\mathrm{CaCl}_{2}(1), \mathrm{NaCl}(120), \mathrm{KCl}(5), \mathrm{BSA}(0.3)$, glucose (5), palmitic acid (0.05), oleic acid (0.05), pH 7.4. After preparation the buffer was vigorously stirred in order to ensure full oxygen saturation. Attached cells $(10 \mathrm{~cm}$ culture dishes) were pre-incubated in buffer $(5 \mathrm{ml})$ for $30 \mathrm{~min}$ at $37^{\circ} \mathrm{C}$. Subsequently, a trace amount $\left[1{ }^{14} \mathrm{C}\right]$ palmitic acid was added and the pre-incubation was continued for an additional $30 \mathrm{~min}$ in order to reach a steady-state situation. Thereafter, a vial containing $500 \mu \mathrm{l} \mathrm{CO}_{2}$-trapping medium $(\mathrm{NaOH}, 0.1 \mathrm{M})$ was inserted and the dish was subsequently sealed airtight. Oxidation was terminated immediately $(t=0)$ or after $30 \mathrm{~min}(\mathrm{t}=30)$ by injection of $500 \mu \mathrm{HClO}_{4}(5 \mathrm{M})$ through a silicone seal on the lid of the dish. Pilot studies had shown that $\mathrm{CO}_{2}$ production was linear for at least $60 \mathrm{~min}$ (data not shown). Dishes were stored at $4^{\circ} \mathrm{C}$ overnight after which trapping medium was assessed for ${ }^{14} \mathrm{C}$ activity by liquid scintillation counting. Oxidation capacity was calculated by the trapped ${ }^{14} \mathrm{C}$-activity at $\mathrm{t}=30$ minus trapped ${ }^{14} \mathrm{C}$-activity at $\mathrm{t}=0$ and was expressed as $\mathrm{nmol} \mathrm{CO}_{2} \cdot \mathrm{min}^{-1} \cdot \mathrm{mg}^{-1}$ total protein. Total protein was quantified using the micro BCA method (Pierce, Rockford IL, USA) with BSA as standard.

\section{Statistics}

Results are obtained from at least six different cell isolations and presented as means $\pm \mathrm{SD}$. Comparison between groups was performed with one-way analysis of variance (ANOVA). In case the F-ratio obtained indicated that significant differences between groups were present, a two-tailed Student's t-test for unpaired data was carried out, applying Bonferroni's adjustment for multiple comparison [36]. Differences were considered significant at $p<0.05$.

\section{Results}

Fatty acids and cardiomyocyte phenotype

First, it was investigated whether the phenotype of neonatal ventricular myocytes was affected by the addition of fatty acids. After $48 \mathrm{~h}$ of culture in defined medium

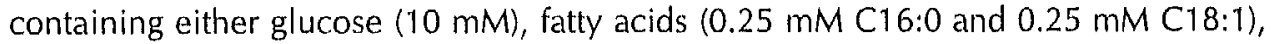
or a combination of glucose plus fatty acids as substrate, differences in cellular morphology were not apparent (e.g. no differences in sarcomere content or organisation). In all groups the cells were irregular in shape and of comparable size. Differences in cellular protein content were not observed (Table 3.1). These observations indicate that the mere presence of $\mathrm{C} 16: 0 / \mathrm{C} 18: 1$ in the culture medium for $48 \mathrm{~h}$ does not give rise to obvious phenotypical alterations of the cardiomyocytes. The latter finding is corroborated by the fact that fatty acids neither induced 
Table 3.1 Effect of substrate on cardiomyocyte protein content and ANF and SERCA2 expression.

\begin{tabular}{lccc}
\hline Substrate(s) & Protein content & ANF mRNA & SERCA2 mRNA \\
\hline Glucose & $1.0 \pm 0.4$ & $1.0 \pm 0.3$ & $0.8 \pm 0.4$ \\
Fatty acids & $0.8 \pm 0.1$ & $1.1 \pm 0.7$ & $0.8 \pm 0.2$ \\
Glucose + fatty acids & $0.9 \pm 0.2$ & $0.8 \pm 0.7$ & $1.0 \pm 0.2$ \\
\hline
\end{tabular}

Differences in total cellular protein content, or atrial natriuretic factor (ANF) and sarcoplasmic reticulum $\mathrm{Ca}^{2+}$-ATPase 2 (SERCA2) mRNA levels were not detected. The levels relative to the control group (only glucose as substrate), the level of expression of which was arbitrarily set at 7.0 , are shown. Messenger RNA levels of ANF and SERCA2 were first normalised to the corresponding 185 ribosomal RNA signal to correct for possible differences in loading. Data presented as means $\pm 5 D$ of at least 6 independent cell cultures.

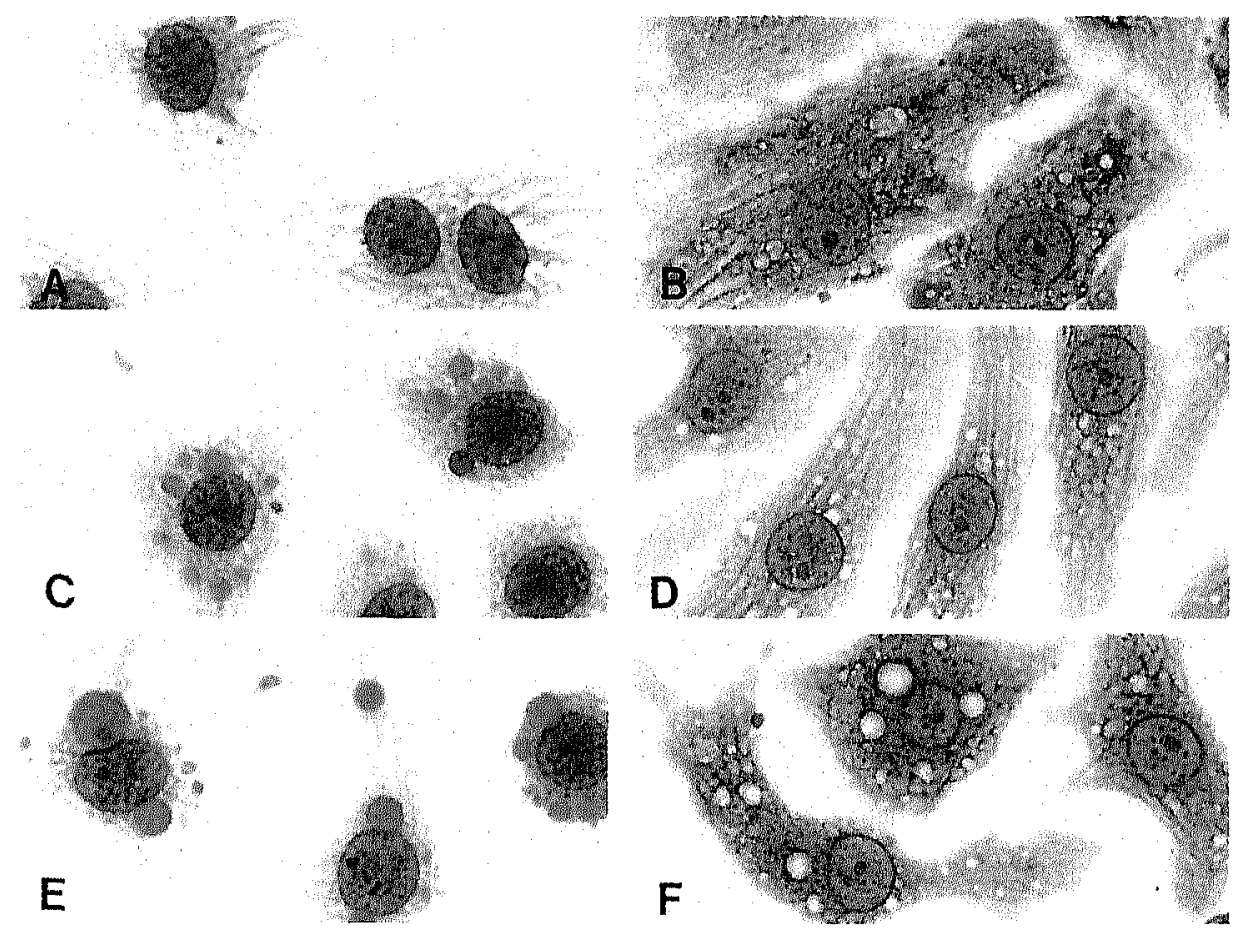

Figure 3.1 Effect of substrate on triacylglycerol (panel A,C,E) and glycogen (panel B,D,F) content in neonatal cardiomyocytes. To visualise neutral lipids cells were stained with Oil Red-O. The periodic acid-Schiff reagent was used to detect glycogen (note differences in intensity of staining). Cells were cultured in the presence of either glucose $(A, B)$, fatty acids, i.e. palmitate/oleate mixture $(C, D)$, or a combination of glucose and these fatty acids $(E, F)$ for $48 \mathrm{~h}$. 
expression of the hypertrophic marker gene atrial natriuretic factor (ANF), nor affected SERCA2 mRNA levels (Table 3.1).

\section{Endogenous substrate stores}

Despite the absence of overt differences in cardiomyocyte phenotype cytochemical staining revealed that variation of exogenous substrate supply induced marked changes in intracellular substrate stores (Fig. 3.1). When glucose was the only substrate available neutral lipids were occasionally observed and appeared as small droplets in the cytoplasm (Fig. 3.1A). In contrast, glycogen was abundantly present throughout the cytoplasm (Fig. 3.1B). Exposing the cells to fatty acids instead of glucose, resulted in the depletion of glycogen granules and a marked increase of lipid droplets (Figs. 3.1C and 3.1D). In the presence of glucose as well as fatty acids the cardiomyocytes accumulated substantial amounts of both glycogen and triacylglycerols during the $48 \mathrm{~h}$ incubation period (Figs. 3.1E and 3.1F).

\section{Expression of genes involved in metabolism}

Next it was tested whether the changes in substrate handling, as suggested by the cytochemical observations, were associated with changes in the expression of genes involved in glucose and fatty acid transport and metabolism. Northern blot analysis of neonatal myocytes cultured in the presence of different (combinations of substrates revealed that the mRNA levels of FAT/CD36, H-FABP, ACS and LCAD were strongly affected by the presence of $\mathrm{C} 16: 0 / \mathrm{C} 18: 1$ in the culture medium (Fig. 3.2). Relative to cardiomyocytes exposed to glucose as the sole substrate, there was a 2- to 4-fold increase in the mRNA levels of FAT/CD36, H-FABP, ACS and LCAD when cells received either fatty acids as the sole substrate, or a combination of glucose and fatty acids (Fig. 3.2A). In contrast, when fatty acids were present in the medium, either as the sole substrate or in combination with glucose, the mRNA levels of GLUT4 significantly declined to $56 \%$ and $41 \%$, respectively, of the level in cells receiving glucose as the only substrate (Fig. 3.2B). The changes of HKII and GAPDH were in the same direction, but less pronounced.

\section{Fatty acid oxidation}

The rate of fatty acid oxidation was determined in intact cells following $48 \mathrm{~h}$ of incubation with glucose only, fatty acids only, or the combination of glucose and fatty acids. The oxidation of exogenously administered $\left[1{ }^{14} \mathrm{C}\right]$ palmitate, as measured as ${ }^{14} \mathrm{CO}_{2}$ production, amounted to $0.12 \pm 0.04 \mathrm{nmol} \cdot \mathrm{min}^{-1} \cdot \mathrm{mg}^{-1}$ protein in cardiomyocytes previously exposed to glucose as the only substrate. When the cells had received fatty acids as substrate (with or without glucose) an almost $70 \%$ increase in the rate of ${ }^{14} \mathrm{CO}_{2}$ production was observed (Fig. 3.3). This finding indicates that the fatty acid-mediated activation of genes involved in fatty acid transport and metabolism is accompanied by an enhanced catabolic flux through this metabolic pathway. 
A

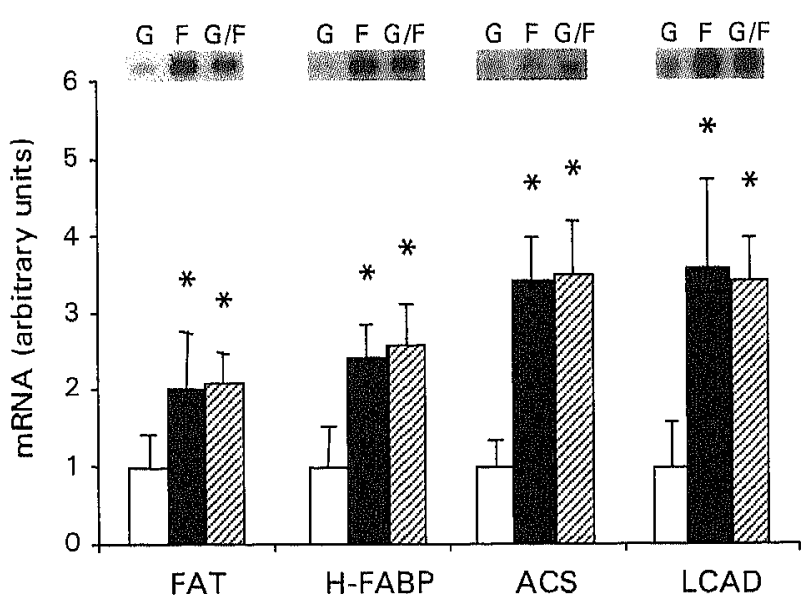

B

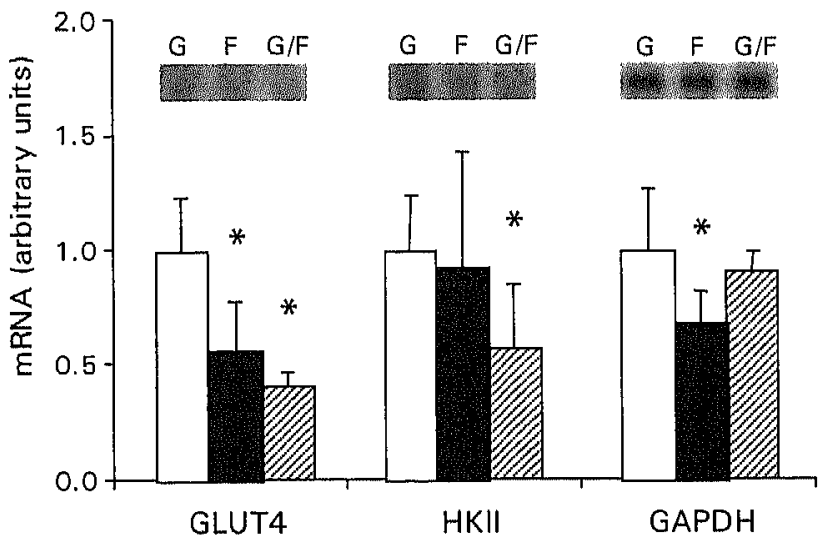

Figure 3.2 Effect of fatty acids on cardiomyocyte mRNA levels. Cells were cultured with either glucose ( $G$, open bars), fatty acids ( $F$, black bars), or glucose plus fatty acids $(G / F$, hatched bars) for $48 \mathrm{~h}$. Changes in mRNA levels of fatty acid translocase/CD36 (FAT), fatty acid-binding protein ( $\mathrm{H}$ FABP), acyl-COA synthetase (ACS), and long-chain acyl-COA dehydrogenase (LCAD) are shown in panel A. Glucose transporter type 4 (GLUT4), hexokinase II (HKII) and glyceraldehyde-3-phosphate dehydrogenase (CAPDH) are shown in panel B. Representative northern blot signals of the mRNAs investigated are included. The expression levels relative to the control group (only glucose as substrate), the level of expression of which was arbitrarily set at 1.0, are shown. mRNA levels were first normalised to the corresponding 185 ribosomal RNA signal to correct for differences in loading. Data are presented as means \pm SD of at least 6 independent cell cultures. * indicates significantly different $(p<0.05)$ from the glucose group.

\section{Effects of PPAR-ligands}

As fatty acids have been implicated to act as natural ligands for PPARs [28] it was investigated whether $W_{y-14,643}(100 \mu \mathrm{M})$ and ciglitazone $(10 \mu \mathrm{M})$, established ligands for PPAR $\alpha$ and PPAR $\gamma$, respectively, were able to mimic the effects of fatty 
acids on cardiomyocyte gene expression. At these concentrations $W y-14,643$ and ciglitazone were previously shown to be effective and isoform-specific in other cell types $[37,40]$. In cells receiving glucose as the sole substrate the addition of the PPAR $\gamma$-specific ligand ciglitazone did not have any effect on the mRNA levels of ACS, LCAD, or GLUT4 (Fig. 3.4). In contrast, administration of the PPAR $\alpha$-selective ligand Wy-14,643 led to markedly enhanced mRNA levels of ACS and LCAD, without affecting GLUT4 mRNA levels.

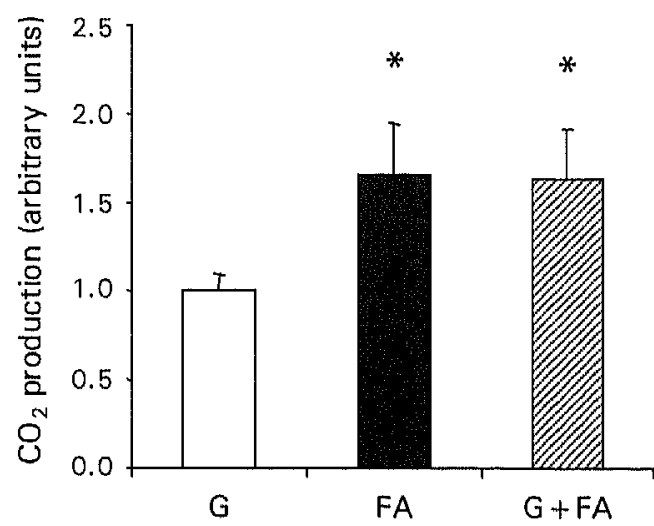

Figure 3.3 Cardiomyocyte long-chain fatty acid oxidation capacity. Neonatal cardiomyocytes were cultured in the presence of either glucose (G), fatty acids (F), or glucose plus fatty acids $(G+F A)$ as substrate(s) for $48 \mathrm{~h}$. Subsequently $\left[1-{ }^{14} \mathrm{C}\right]$ palmitate oxidation was measured as the steady state rate of ${ }^{14} \mathrm{CO}_{2}$ production (the glucose group being arbitrarily set at 1.0 ). Data are presented as means $\pm S D$ of 5 independent cell cultures. * indicates significantly different $(p<0.05)$ from glucose-group.

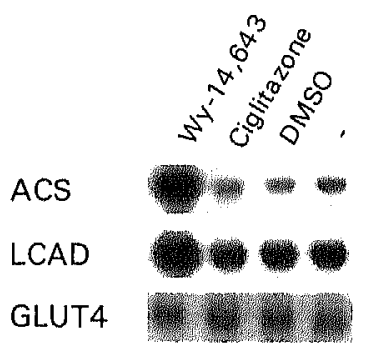

Figure 3.4 Representative northern blot, displaying the effects of the PPAR $\alpha$ ligand $W y-14,643$ and the PPAR ligand ciglitazone on cardiomyocyte mRNA levels of acyl-CoA synthetase (ACS), longchain acyl-CoA dehydrogenase (LCAD) and glucose transporter type 4 (GLUT4). Cardiomyocytes were cultured in minimal medium, with glucose as the only substrate, without any addition $(-)$, or in the presence of DMSO (vehicle), ciglitazone $(10 \mu \mathrm{M})$ or $W y-14,643(100 \mu \mathrm{M})$, for $48 \mathrm{~h}$. 


\section{Discussion}

It is demonstrated for the first time that exposure of neonatal rat ventricular myocytes to long-chain fatty acids enhances their capacity to oxidise fatty acids by selectively and co-ordinately increasing the mRNA levels of genes involved in cellular fatty acid transport, i.e. FAT/CD36 [1,13,14] and H-FABP $[10,35]$, as well as fatty acid metabolism, i.e. ACS and LCAD.

In the present study palmitic $\left(C_{16: 0)}\right.$ and oleic acid (C18:1) were chosen as exogenous fatty acid substrates as, from a quantitative point of view, these fatty acids constitute the most important fatty-acyl moieties in rat blood [34]. Previous findings [7] (M.M. Vork, unpublished observations) indicated that these fatty acids are readily taken up, incorporated in endogenous lipid pools, and oxidised by the neonatal myocytes. As opposed to polyunsaturated fatty acids, $\mathrm{C} 16: 0$ and $\mathrm{C} 18: 1$ do not function as precursors of eicosanoids. This implies that the observed effects on gene expression are due to the fatty acids themselves, rather than to the formation of biologically active cyclooxygenase or lipoxygenase products, which have been shown to act as auto/paracrine factors inducing cardiomyocyte hypertrophy [2]. The observation that exposure to saturated and monounsaturated fatty acids neither gives rise to changes in cellular protein content, nor to the induction of hypertrophic marker genes like ANF, supports this notion.

Along with the marked increases in the mRNA levels of genes involved in fatty acid handling, the mRNA content of proteins involved in glucose handling (GLUT4, HKII, GAPDH) tended to decline. Generally speaking, however, the changes observed in the mRNA levels appear to be less consistent and less pronounced. The physiological relevance of these changes, as far as glucose metabolism is concerned, remains to be established.

\section{Putative mechanism of fatty acid-mediated gene expression}

Effects of fatty acids on gene expression have also been documented in studies with other cell types, such as adipocytes, hepatocytes, and skeletal muscle cells $[5,15,29]$. As far as the mechanism is concerned, evidence is accumulating for the existence of fatty acid-mediated transcriptional regulation of various genes involved in lipid metabolism. In a number of cases the responsive cis-regulatory element has been identified as a peroxisome proliferator-responsive element (PPRE) that binds peroxisome proliferator-activated receptors (PPARs), members of the nuclear hormone receptor family $[24,28,41]$. Recent studies have provided strong evidence that, in addition to prostaglandins, long-chain fatty acids may act as natural ligands for PPARs $[4,17]$. The PPARs display limited specificity with respect to various long-chain fatty acid species. Of note is the recent observation that the affinity of palmitic and oleic acid for the different PPAR isoforms is comparable to that of polyunsaturated fatty acids [39].

Both the $\alpha$ and $\beta$ isoform, but probably not the $\gamma$ isoform, of PPAR are expressed in the heart (see [32] for review). The current finding that a PPAR $\alpha$ ligand, but not a PPAR $\gamma$ ligand, is able to affect gene expression in cardiomyocytes supports the notion 
that PPAR $\gamma$ is either not present and/or of limited functional importance for cardiac myocytes. In line with this notion is the observation that the PPARy ligand ciglitazone stimulates the expression of GLUT4 in adipocytes [38], whereas no such effect is observed in neonatal cardiomyocytes (see Fig. 3.4). The observation that FAT/CD36 expression in liver is induced by PPAR $\alpha$ ligands, but not by PPAR $\gamma$ ligands [21], also fits with this idea.

The fact that fatty acids and the PPAR $\alpha$-specific ligand Wy-14,643 have similar effects on cardiomyocyte mRNA levels, is in favour of the idea that these effects of fatty acids are PPAR $\alpha$-mediated. Indeed, a variety of genes involved in cardiac lipid metabolism, among which FAT/CD36 and ACS are PPAR-responsive [21,28,32]. Just recently it was demonstrated that the expression of muscle-type CPT1 is also PPAR $\alpha-$ dependent [20] and that exposure of neonatal cardiomyocytes to long-chain fatty acids activates transcription of the MCPT1 promoter via a PPRE [6].

\section{(Patho-)physiological implications}

Under normal conditions glucose and fatty acids each serve as substrates for the cardiac muscle. In adult rats fatty acids are the substrate of preference, the oxidation of which covers over $60-70 \%$ of the cardiac energy requirements [22,33]. It is of interest to note that cardiac substrate preference undergoes substantial alterations during development. Carbohydrates are the substrates of choice for the foetal heart, whereas in the postnatal period the heart rapidly switches to fatty acids as its main energy source [18]. It is generally believed that the alterations in substrate utilisation and concordant changes in the activity of enzymes involved in fatty acid utilisation are primarily caused by the postnatal changes in circulating levels of hormones, such as insulin, glucagon, and thyroid hormone [9]. The present findings, however, suggest that in addition to hormonal regulation, the change in nutrient supply around birth (i.e. from maternal blood to lipid-rich milk) in the intact animal could directly be responsible for these in vivo changes.

Furthermore, several pathophysiological conditions (e.g. diabetes and cardiac hypertrophy and failure) are associated with a marked change in the plasma concentrations of substrates and/or a marked shift in substrate preference of the cardiac muscle cells $[3,16,25]$. Evidence is accumulating that the metabolic adaptation most likely can be ascribed to alterations in the expression of the genes involved $[8,26,27]$. It remains, however, to be determined whether fatty acid-induced and/or PPAR-mediated changes in cardiac gene-expression contribute to the aetiology of these diseases.

In conclusion, it is demonstrated that long-term exposure of cardiac muscle cells to fatty acids evokes a co-ordinated upregulation of the expression of genes involved in lipid metabolism, with a concomitant increase in the cellular capacity to oxidise exogenous fatty acids. These findings clearly indicate that the cardiac myocyte is responsive to metabolic signals. In addition, evidence is provided that PPARs are likely to be part of the signalling pathway that conveys this metabolic signal to the transcriptional machinery of the cardiomyocyte. 


\section{Acknowledgements}

The research was funded by grants 97.092 and D98.015 of the Netherlands Heart Foundation and by grant 902-16-098 of the Netherlands Foundation of Scientific Research. The research of $M$. van Bilsen has been made possible by a fellowship of the Royal Netherlands Academy of Arts and Sciences.

\section{References}

1. Abumrad NA, El-Maghrabi MR, Amri EZ, Lopez E, and Grimaldi PA (1993). Cloning of a rat adipocyte membrane protein implicated in binding or transport of long-chain fatty acids that is induced during preadipocyte differentiation. Homology with human CD36. / Biol Chem 268, 17665-17668

2. Adams JW, Migita DS, Yu MK, Young R, Hellickson MS, Castro-Vargas FE, Domingo JD, Lee $\mathrm{PH}$, Bui JS, and Henderson SA (1996). Prostaglandin F2 $\alpha$ stimulates hypertrophic growth of cultured neonatal rat ventricular myocytes. I Biol Chem 271, 1179-1186

3. Allard MF, Schönekess BO, Henning SL, English DR, and Lopaschuk GD (1994). Contribution of oxidative metabolism and glycolysis to ATP production in hypertrophied hearts. Am / Physiol 267, H742-H750

4. Amri E-Z, Bonino F, Ailhaud G, Abumrad NA, and Grimaldi PA (1995). Cloning of a protein that mediates transcriptional effects of fatty acids in preadipocytes. Homology to peroxisome proliferator-activated receptors. J Biol Chem 270, 2367-2371

5. Amri E-Z, Teboul L, Vannier C, Grimaldi P-A, and Ailhaud G (1996). Fatty acids regulate the expression of lipoprotein lipase gene and activity in preadipose and adipose cells. Biochem / 314, 541-546

6. Brandt JM, Djouadi F, and Kelly DP (1998). Fatty acids activate transcription of the muscle carnitine palmitoyltransferase I gene in cardiac myocytes via the peroxisome proliferatoractivated receptor $\alpha$. / Biol Chem 273, 23786-23792

7. De Vries JE, Vork MM, Roemen THM, de Jong YF, Cleutjens JPM, van der Vusse GJ, and van Bilsen $M$ (1997). Saturated but not mono-unsaturated fatty acids induce apoptotic cell death in neonatal rat ventricular myocytes. / Lipid Res 38, 1384-1394

8. Depre C, Shipley GL, Chen W, Han Q, Doenst T, Moore ML, Stepkowski S, Davies PJA, and Taegtmeyer $H$ (1998). Unloaded heart in vivo replicates fetal gene expression of cardiac hypertrophy. Nature Med 4, 1269-1275

9. Girard J, Ferré P, Pégorier J-P, and Duée P-H (1992). Adaptations of glucose and fatty acid metabolism during perinatal period and suckling-weaning transition. Physiol Rev 72, 507-562

10. Glatz JF and van der Vusse GJ (1996). Cellular fatty acid-binding proteins; their function and physiological significance. Prog Lipid Res 35, 243-282

11. Göttlicher M, Widmark E, Li Q, and Gustafsson J-Ä (1992). Fatty acids activate a chimera of the clofibric acid-activated receptor and the glucocorticoid receptor. Proc Natl Acad Sci USA 89, 4653-4657

12. Grimaldi PA, Knobel SM, Whitesell RR, and Abumrad NA (1992). Induction of aP2 gene expression by nonmetabolized long-chain fatty acids. Proc Natl Acad Sci USA 89, 10930 10934

13. Harmon CM and Abumrad NA (1993). Binding of sulfosuccinimidyl fatty acids to adipocyte membrane proteins: isolation and amino-terminal sequence of an $88-\mathrm{kD}$ protein implicated in transport of long-chain fatty acids. / Membr Biol 133, 43-49

14. Ibrahimi A, Sfeir Z, Magharaie H, Amri EZ, Grimaldi P, and Abumrad NA (1996). Expression of the CD36 homolog (FAT) in fibroblast cells: effects on fatty acid transport. Proc Natl Acad SCIUSA 93, 2646-2651 
15. Jump DB, Ren B, Clarke S, and Thelen A (1995). Effects of fatty acids on hepatic gene expression. Prostaglandins Leukot Essent Fatty Acids 52, 107-111

16. Kagaya $Y$, Kanno Y, Takeyama D, Ishide N, Maruyama $Y$, Takahashi T, Ido T, and Takishima T (1990). Effects of long-term pressure overload on regional myocardial glucose and free fatty acid uptake in rats. A quantitative autoradiographic study. Circulation 81, 1353-1361

17. Kliewer SA, Sundseth SS, Jones SA, Brown PJ, Wisely GB, Koble CS, Devchand P, Wahli W, Willson TM, Lenhard JM, and Lehmann JM (1997). Fatty acids and eicosanoids regulate gene expression through direct interactions with peroxisome proliferator-activated receptors $\alpha$ and \%. Proc Natl Acad Sci USA 94, 4318-4323

18. Lopaschuk GD, Collins-Nakai RL, and Itoi $T$ (1992). Developmental changes in energy substrate use by the heart. Cardiovasc Res 26, 1172-1180

19. Luiken JJFP, van Nieuwenhoven FA, America G, van der Vusse GJ, and Glatz JFC (1997). Uptake and metabolism of palmitate by isolated cardiac myocytes from adult rats: involvement of sarcolemmal proteins. / Lipid Res 38, 745-758

20. Mascaró C, Acosta E, Ortiz JA, Marrero PF, Hegardt FG, and Haro D (1998). Control of human muscle-type carnitine palmitoyltransferase I gene transcription by peroxisome proliferator. activated receptor. I Biol Chem 273, 8560-8563

21. Motojima K, Passilly P, Peters JM, Gonzalez FJ, and Latruffe N (1998). Expression of putative fatty acid transporter genes are regulated by peroxisome proliferator-activated receptor $\alpha$ and $\gamma$ activators in a tissue- and inducer-specific manner. / Bio/ Chem 273, 16710-16714

22. Neely JR and Morgan HE (1974). Relationship between carbohydrate and lipid metabolism and the energy balance of heart muscle. Annu Rev Physiol 36, 413-459

23. Prophet EB, Mills B, Arrington JB, and Robin LH (1993). Laboratory methods in histotechnology. American Registry of Pathology, Washington, DC

24. Ren B, Thelen A, and Jump DB (1996). Peroxisome proliferator-activated receptor a inhibits hepatic $\$ 14$ gene transcription. Evidence against the peroxisome proliferator-activated receptor a as the mediator of polyunsaturated fatty acid regulation of $\$ 14$ gene transcription. / Biol Chem 271, 17167-17173

25. Rodrigues B and MCNeill JH (1992). The diabetic heart: metabolic causes for the development of a cardiomyopathy. Cardiovasc Res 26, 913-922

26. Sack MN, Disch DL, Rockman $H A$, and Kelly DP (1997). A role for Sp and nuclear receptor transcription factors in a cardiac hypertrophic growth program. Proc Natl Acad Sci USA 94, 6438-6443

27. Sack MN, Rader TA, Park S, Bastin J, McCune SA, and Kelly DP (1996). Fatty acid oxidation enzyme gene expression is downregulated in the failing heart. Circulation 94, 2837-2842

28. Schoonjans K, Staels B, and Auwerx J (1996). Role of the peroxisome proliferator-activated receptor (PPAR) in mediating the effects of fibrated and fatty acids on gene expression. / Lipid Res 37, 907-925

29. Teboul L, Gaillard D, Staccini L, Inadera H, Amri E-Z, and Grimaldi PA (1995). Thiazolidinediones and fatty acids convert myogenic cells into adipose-like cells. / Biol Chem 270, 28183-28187

30. Van Bilsen M, de Vries JE, and van der Vusse GJ (1997). Long-term effects of fatty acids on cell viability and gene expression of neonatal cardiac myocytes. Prostaglandins Leukot Essent Fatty Acids $57,30-45$

31. Van Bilsen $M$ and van der Vusse GJ (1995). Phospholipase- $A_{2}$-dependent signalling in the heart. Cardiovasc Res 30, 518-529

32. Van Bilsen $M$, van der Vusse $G$ ), and Reneman RS (1998). Transcriptional regulation of metabolic processes: implications for cardiac metabolism. Eur J Physiol 437, 2-14

33. Van der Vusse G], Glatz JFC, Stam HCG, and Reneman RS (1992). Fatty acid homeostasis in the normoxic and ischemic heart. Physiol Rev 72, 881-940

34. Van der Vusse G), Roemen TH, Flameng W, and Reneman RS (1983). Serum-myocardium gradients of non-esterified fatty acids in dog, rat and man. Biochim Biophys Acta 752, 361-370 
35. Van Nieuwenhoven FA, Verstijnen $C P$, Abumrad NA, Willemsen $P H$, van Eys $G$, van der Vusse GJ, and Glatz JF (1995). Putative membrane fatty acid translocase and cytoplasmic fatty acid-binding protein are co-expressed in rat heart and skeletal muscles. Biochem Biophys Res Commun 207, 747-752

36. Wallenstein S, Zucker CL, and Fleiss JL (1980). Some statistical methods useful in circulation research. Circ Res 47, 1.9

37. Willson TM, Cobb JE, Cowan DJ, Wiethe RW, Correa ID, Prakash SR, Beck KD, Moore LB, Kliewer SA, and Lehmann JM (1996). The structure-activity relationship between peroxisome proliferator-activated receptor $\gamma$ agonism and the antihyperglycemic activity of thiazolidinediones. / Med Chem 39, 665-668

38. Wu Z, Xie Y, Morrison RF, Bucher NLR, and Farmer SR (1998). PPAR $\gamma$ induces the insulindependent glucose transporter GLUT4 in the absence of C/EBP $\alpha$ during the conversion of $3 T 3$ fibroblasts into adipocytes. I Clin Invest 101, 22-32

39. Xu HE, Lambert MH, Montana VG, Parks DJ, Blanchard SG, Brown PJ, Sternbach DD, Lehmann JM, Wisely GB, Willson TM, Kliewer SA, and Milburn MV (1999). Molecular recognition of fatty acids by peroxisome proliferator-activated receptors. Mol Cell 3, 397-403

40. Yu K, Bayona W, Kallen CB, Harding HP, Ravera CP, McMahon G, Brown M, and Lazar MA (1995). Differential activation of peroxisome proliferator-activated receptors by eicosanoids. I Biol Chem 270, 23957-23983

41. Zhang B, Marcus SL, Sajjadi FG, Alvares K, Reddy JK, Subramani S, Rachubinski RA, and Capone JP (1992). Identification of a peroxisome proliferator-responsive element upstream of the gene encoding rat peroxisomal enoyl-CoA hydratase/3-hydroxyacyl-CoA dehydrogenase. Proc Natl Acad Sci USA 89, 7541-7545 


\section{4}

\section{PPAR $\alpha$ and PPAR $\beta / \delta$ modulate expression}

of cardiac genes coding for fatty acidhandling proteins

Karin AJM van der lee, Peter HM Willemsen, Ger J van der Vusse, and Marc van Bilsen

Department of Physiology, Cardiovascular Research Institute Maastricht, Maastricht University, the Netherlands 


\section{Abstract}

Fatty acids are able to induce the expression of a panel of genes encoding proteins involved in cellular fatty acid uptake and metabolism in neonatal rat cardiomyocytes. To explore the involvement of the different PPAR isoforms in this process, neonatal rat cardiac myocytes and embryonic rat heart-derived $H 9 \mathrm{c} 2$ cells were treated with $W y-14,643$, L-165041, ciglitazone, specific ligands for PPAR $\alpha$, PPARB/ $\delta$, PPAR, respectively, and fatty acids for 48 hours. Fatty acids increased the expression of the fatty acid-handling proteins acyl-CoA synthetase (ACS) and long-chain acyl-CoA dehydrogenase (LCAD) and of the uncoupling protein UCP-2 only modestly in $\mathrm{H} 9 \mathrm{C} 2$ cells, when compared to neonatal cardiomyocytes. Whereas PPAR be detected in neonatal cardiomyocytes and H9c2 cells and PPARB/ $\delta$ was expressed in both cell types, PPAR $\alpha$ mRNA was only detectable in neonatal cardiac muscle cells. The effects of the specific PPAR agonists appeared to corroborate the distribution of the PPAR isoforms. Thus, the PPAR $\gamma$ ligand ciglitazone was ineffective in both neonatal cardiomyocytes and $H 9 \mathrm{c} 2$ cells, and the PPAR $\alpha$ ligand $W y-14,643$ only increased the expression of fatty acid metabolic genes in neonatal cardiac cells. In contrast, the PPAR $\beta / \delta$ ligand $L-165041$ mimicked the effects of fatty acids in both $\mathrm{H} 9 \mathrm{C} 2$ cells and neonatal cardiomyocytes, although in the latter cell type the degree of induction of $A C S, L C A D$ and UCP-2 expression by the PPAR $\beta / \delta$ agonist was moderate as compared to the PPAR $\alpha$ agonist. In conclusion, PPAR $\gamma$ does not play a role in fatty acid-induced cardiac gene expression, whereas PPAR $\alpha$ and $P P A R \beta / \delta$ appear to be redundant in this process.

\section{Introduction}

Over the past decade it has become generally acknowledged that dietary factors, among which major substrates as glucose and fatty acids, act as signalling molecules that modulate gene expression in a variety of tissues, including the heart (for review see [37]). Using primary cultures of neonatal rat cardiomyocytes, we recently demonstrated that fatty acids markedly enhance the expression of genes encoding proteins involved in cardiac fatty acid transport and metabolism $[36,38]$. In addition, evidence was provided that the effects of fatty acids may be mediated by peroxisome proliferator-activated receptors (PPARs) $[12,38]$. PPARs are nuclear transcription factors playing an important role in the regulation of whole-body and cellular lipid metabolism (reviewed in $[15,34])$. Until now, three PPAR subtypes have been described, designated PPAR $\alpha$, PPAR $\beta / \delta$ and PPAR $\gamma$. Thus far, studies have mainly focussed on PPARQ and PPAR $\gamma$, and distinct roles for these PPAR isoforms in lipid metabolism have been revealed. Whereas PPAR $\alpha$ plays a predominant role in the regulation of lipid catabolism, PPAR $y$ is a regulator of adipocyte differentiation $[15,34]$. The function of the ubiquitously expressed PPAR $\beta / \delta$ is still unknown as is the 
answer to the question whether it may play a role in lipid metabolism like the other PPAR isoforms.

Through the development of specific ligands for PPAR $\alpha$, PPAR $\gamma$ and, more recently, for PPAR $\beta / \delta[8,44,45]$, valuable tools have become available to decipher the biological roles of each of the PPAR isoforms in more detail. This prompted us to investigate the specific roles of PPAR $\alpha,-\beta / \delta$ and $-\gamma$ in the cardiac muscle cell, with respect to the regulation of genes encoding proteins involved in fatty acid metabolism. The well-characterised neonatal rat cardiomyocyte as well as the embryonic rat heartderived $\mathrm{H} 9 \mathrm{c} 2$ cell line were used as experimental models. Similar to skeletal muscle cell lines, $\mathrm{H} 9 \mathrm{c} 2$ cells are able to differentiate from myoblasts into multinucleated myotubes [25]. As others have demonstrated that cellular metabolism as well as the expression of metabolic genes alters during differentiation of muscle-derived cells $[24,30,32,33]$, both myoblasts and myotubes were studied. Preliminary investigations already indicated that, compared to neonatal cardiomyocytes, $\mathrm{H} 9 \mathrm{c} 2$ cells appear to be less responsive to fatty acids [39]. Accordingly, the question was asked whether this could be attributed to differences in PPAR isoform content. To this end, $\mathrm{H} 9 \mathrm{c} 2$ myoblasts, $\mathrm{H} 9 \mathrm{c} 2$ myotubes and neonatal cardiomyocytes were cultured in defined medium in the absence or presence of fatty acids, being a combination of palmitic and oleic acid, for 48 hours. To investigate the role of each of the three PPAR isoforms in more detail, the PPAR isoform distribution pattern in neonatal cardiomyocytes, and in non-differentiated and differentiated $\mathrm{H} 9 \mathrm{c} 2$ cells was assessed at the mRNA level. Ultimately, the effects of $W y-14,643, L-165041$ and ciglitazone, specific ligands for PPAR $\alpha, \operatorname{PPAR} \beta / \delta$ and PPAR $\gamma$, respectively, on metabolic gene expression in neonatal cardiac myocytes, $\mathrm{H} 9 \mathrm{c} 2$ myoblasts and $\mathrm{H} 9 \mathrm{c} 2$ myotubes were examined.

\section{Materials and methods}

\section{Cell culture}

Neonatal rat ventricular cardiomyocytes were prepared as described previously [13]. Experiments were approved by the Institutional Animal Care and User Committee of the Maastricht University. After isolation, neonatal cardiomyocytes were cultured overnight in serum-rich medium consisting of a $4: 1$ mixture of DMEM (Gibco-BRL Life Technologies, Gaithersburg MD, USA) and M199 (Gibco) supplemented with 10\% horse serum (Gibco), 5\% newborn calf serum (Sera-Lab, Sussex, UK) and antibiotics (gentamicin $0.1 \mathrm{mg} / \mathrm{ml}$, Gibco) before experiments started.

H9c2 cells (ATCC CRL-1446; Rockville MD, USA; passage numbers 18-22) were maintained in growth medium composed of DMEM supplemented with $10 \%$ foetal bovine serum (Gibco). $\mathrm{H} 9 \mathrm{c} 2$ cells were plated at a density of $2000 \mathrm{cells} / \mathrm{cm}^{2}$ and allowed to proliferate in growth medium. Medium was changed twice a week. To induce differentiation of $\mathrm{H} 9 \mathrm{c} 2$ myoblasts into myotubes growth medium was replaced with differentiation medium (DMEM containing $2 \%$ horse serum) when cells had reached near confluence. Cells were considered differentiated after formation of multinucleated myotubes (10-13 days after changing to growth medium). 
At the start of the experiments, $\mathrm{H} 9 \mathrm{c} 2$ myoblasts (at near confluence), H9c2 myotubes and neonatal cardiomyocytes were incubated in serum-free medium consisting of a 4:1 mixture of DMEM/M199, which contained antibiotics and $10 \mathrm{mM}$ glucose as the sole substrate, for $24 \mathrm{~h}$. Subsequently, the cells were rinsed once with substrate-free medium (4:1 mixture of DMEM and M199 with gentamicin), whereupon experimental medium was applied to the cells. The experimental medium consisted of substrate-free medium enriched with $0.25 \mathrm{mM} \mathrm{L}$-carnitine, $0.25 \mathrm{mU} / \mathrm{ml}$ insulin and $0.15 \mathrm{mM}$ bovine serum albumin (BSA; A-7906, Sigma, St. Louis MO, USA). The medium was further supplemented with either $10 \mathrm{mM}$ glucose or a combination of glucose $(10 \mathrm{mM})$ and fatty acids, a mixture of palmitic and oleic acid (0.25 mM each; complexed to $0.15 \mathrm{mM} \mathrm{BSA}$ as described elsewhere [13]). To test the effects of PPAR-specific ligands, cells receiving glucose as the only substrate were

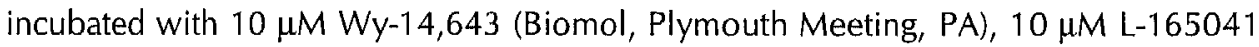
(kindly provided by Dr. J. Berger, Merck, Rahway NJ, USA) or $10 \mu \mathrm{M}$ ciglitazone (Biomol), specific ligands for PPARo, PPAR $\beta / \delta$ and PPAR $\gamma$, respectively. Stock solutions of these PPAR ligands were prepared in DMSO. After $48 \mathrm{~h}$ of incubation cells were harvested for preparation of cell lysates or analysis of RNA.

\section{Adult animal tissues}

Heart and epididymal white adipose tissue were dissected from adult Lewis rats. Tissues were immediately frozen in liquid nitrogen and stored at $-80^{\circ} \mathrm{C}$ until analysis of RNA.

\section{Creatine kinase activity}

Cell lysates were prepared to determine creatine kinase activity. $\mathrm{H} 9 \mathrm{c} 2$ cells, cultured in $3.5 \mathrm{~cm}$ dishes, were washed twice with phosphate-buffered saline (PBS) and incubated in $0.5 \mathrm{ml}$ lysis buffer $(0.5 \%$ triton X-100 in PBS) for $10 \mathrm{~min}$ at room temperature. Total protein content in cell lysates was determined with the micro BCA method (Pierce, Rockford IL, USA), using BSA as standard. Absorbance was read at $450 \mathrm{~nm}$ using a Titertek Multiscan MKII microplate reader. After addition of $1 \%$ BSA, cell lysates were stored at $-80^{\circ} \mathrm{C}$ until further analysis. Creatine kinase (CK; EC 2.7.3.2) activity in cell lysates was analysed on a Cobas Bio centrifugal analyser (Roche Diagnostics, Basel, Switzerland) with an UV-assay using Granutest ${ }^{\boxplus} \mathrm{CK} N$ acetylcysteine (NAC)-activated reagentia (Merck, Darmstadt, Germany). Enzyme activities are expressed per $\mathrm{mg}$ total protein.

\section{RNA analysis}

Total RNA was isolated with TRIzol reagent (Gibco). Twenty $\mu \mathrm{g}$ of total RNA were size-fractionated on a denaturing gel (1\% agarose, $5 \%$ formaldehyde, $1 \times$ MOPS), transferred to a nylon membrane (Hybond-NX, Amersham, Slough, UK) by capillary transfer, and fixed using standard techniques. Following prehybridisation the filters were probed with fragments of CDNA of the glucose transporter GLUT4, hexokinase II (HKII), fatty acid translocase (FAT/CD36), heart-type fatty acid-binding protein ( $\mathrm{H}$ FABP), acyl-CoA synthetase (ACS), long-chain acyl-CoA dehydrogenase (LCAD), or 
uncoupling protein-2 (UCP-2) as described previously [38,40]. A $0.6 \mathrm{~kb}$ Bglll fragment of hexokinase I (HKI; a gift of Dr. J.E. Wilson, Michigan State University, USA), a 0.9 $\mathrm{kb}$ Pstl fragment of mouse peroxisome proliferator-activated receptor $\alpha$ (PPAR $\alpha$; kindly provided by Dr. J. Auwerx, Institute Pasteur, Lille, France), a $1.5 \mathrm{~kb}$ BamHI fragment of rat PPAR $\beta / \delta$ (a gift of Dr. P.A. Grimaldi, University of Nice, France), and a $0.6 \mathrm{~kb}$ Bglll fragment of hamster PPAR $\gamma$ (also provided by Dr. J. Auwerx) were also used for hybridisation as well as a $0.7 \mathrm{~kb}$ fragment of rat UCP-3 generated via RT-PCR using forward (5'-GGCCATCCTCCGGAACCATGG-3') and reversed (5'GCGGCCTGCTTGCCTTGTTCA- $3^{\prime}$ ) primers. The CDNA probes were labelled with [ $\alpha$ $\left.{ }^{32} \mathrm{P}\right] \mathrm{dCTP}(3000 \mathrm{Ci} / \mathrm{mmol}$; Amersham) by random-priming (Radprime, Life Technologies) to a specific activity of $>0.5 \times 10^{9} \mathrm{cpm} / \mu \mathrm{g}$ DNA. To correct for possible differences in transfer and loading the filters were also hybridised with a ${ }^{32} \mathrm{P}$ labelled ribosomal $18 \mathrm{~S}$ probe. Following hybridisation filters were washed at the appropriate stringency to remove non-specific binding. The filters were exposed to imaging screens and subsequently scanned on the Personal FX Imager (Bio-Rad Laboratories, Hercules CA, USA). Signals were quantified using Quantity One software (Bio-Rad Laboratories).

\section{Statistics}

Results are obtained from at least three independent experiments and presented as sample means $\pm S D$. Comparison between groups was performed with one-way analysis of variance (ANOVA). In case the F-ratio obtained indicated that significant differences between groups were present, a two-tailed Student's t-test for unpaired data was carried out, applying Bonferroni's adjustment for multiple comparison [42]. Differences were considered significant at $p<0.05$.

\section{Results}

\section{Differentiation of $\mathrm{H} 9 \mathrm{c} 2$ cells}

In addition to morphological criteria, the phenotype of $\mathrm{H} 9 \mathrm{c} 2$ myoblasts and myotubes was evaluated by measuring cellular creatine kinase (CK) activity. The differentiation of myoblasts into myotubes was accompanied with a more than 8-fold increase in CK activity (Fig. 4.1). Interestingly, the differentiation of $\mathrm{H} 9 \mathrm{C} 2$ blasts into tubes led to an increase of mRNA levels of proteins involved in both glucose (CLUT4, hexokinase II) and fatty acid metabolism (acyl-CoA synthetase, long-chain acyl-CoA dehydrogenase) (Fig. 4.2). In contrast, expression of the uncoupling protein UCP-2 tended to decline during differentiation (Fig. 4.2). Previous studies already demonstrated that, unlike cardiac myocytes, $\mathrm{H} 9 \mathrm{C} 2$ myoblasts do not express the transsarcolemmal fatty acid translocase FAT/CD36 and the cytosolic fatty acid-binding protein H-FABP under basal conditions [31,41]. The differentiation of $\mathrm{H} 9 \mathrm{c} 2$ myoblasts into myotubes, however, did not result in induction of either FAT/CD36 or H-FABP expression. 


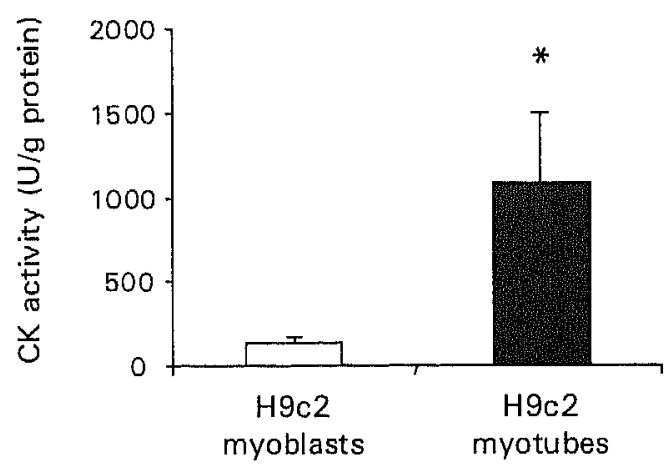

Figure 4.1 Creatine kinase (CK) activity in $\mathrm{H} 9 \mathrm{c} 2$ myoblasts and myotubes. $\mathrm{H} 9 \mathrm{c} 2$ cells were cultured in the presence of glucose as the only substrate for $48 \mathrm{~h}$. Data are presented as means $\pm \mathrm{SD}$ ( $n \geq 21$ from six independent experiments). * indicates significantly different $(p<0.001)$ from myoblasts.

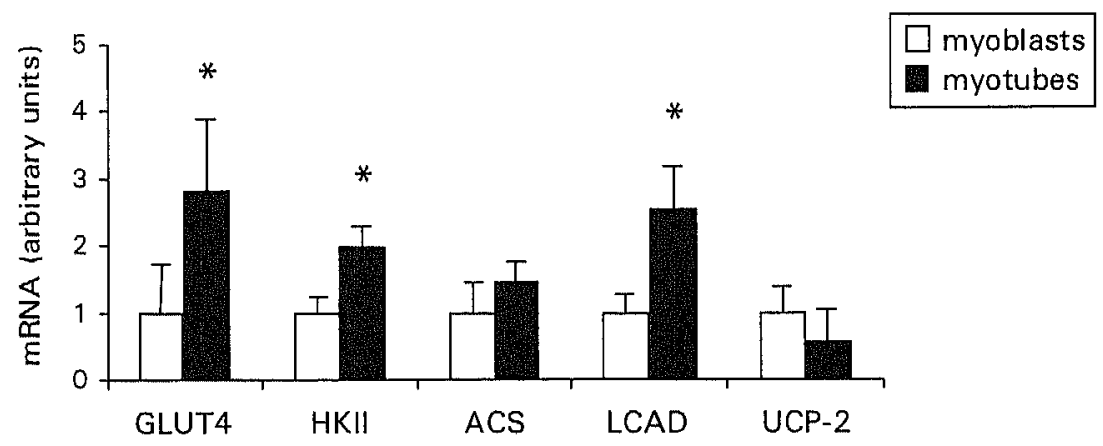

Figure 4.2 Effect of $\mathrm{H} 9 \mathrm{C} 2$ cell differentiation on expression of genes coding for the glucose transporter GLUT4, hexokinase II (HKII), acyl-CoA synthetase (ACS), long-chain acyl-CoA dehydrogenase (LCAD), and the uncoupling protein UCP-2. H9C2 myoblasts and myotubes were cultured in the presence of glucose as the only substrate for $48 \mathrm{~h}$. The expression levels in myotubes relative to myoblasts, the level of expression that was arbitrarily set at 1.0, are shown. mRNA levels were first normalised to the corresponding 185 ribosomal signal to correct for differences in loading. Data are presented as means $\pm S D$ ( $n \geq 5$ from at least three independent experiments). * indicates significantly different $(p<0.01)$ from myoblasts.

\section{Effects of fatty acids on gene expression}

To examine the effects of fatty acid suppletion on gene expression in more detail, $\mathrm{H} 9 \mathrm{c} 2$ myoblasts and myotubes, and neonatal rat cardiomyocytes were cultured in the presence of either glucose as the sole substrate or a combination of glucose and fatty acids (palmitic and oleic acid) for $48 \mathrm{~h}$. After exposure to fatty acids, the expression of the glucose transporter GLUT4 was not altered in $\mathrm{H} 9 \mathrm{c} 2$ myoblasts but was more than $50 \%$ reduced in $\mathrm{H} 9 \mathrm{c} 2$ myotubes and neonatal cardiomyocytes (Fig. 4.3A). In both 
$\mathrm{H} 9 \mathrm{c} 2$ myoblasts and myotubes, and in cardiac myocytes the expression of hexokinase II (HKII) declined over $30 \%$ following fatty acid suppletion (Fig. 4.3B). In contrast, the expression of LCAD and UCP-2 significantly increased in all cell types during the $48 \mathrm{~h}$ exposure to fatty acid-containing medium, although the increase was more pronounced in neonatal cardiomyocytes than in $\mathrm{H} 9 \mathrm{c} 2$ cells (Figs. 4.4B and 4.4C). As far as the expression of ACS is concerned, the effects of fatty acids appeared to be cell type dependent (Fig. 4.4A). In cardiac myocytes fatty acids induced a 3.5-fold rise in ACS mRNA content. In contrast, ACS expression appeared to be unresponsive to fatty acids in $\mathrm{H} 9 \mathrm{c} 2$ myoblasts and increased only modestly (1.5-fold) in $\mathrm{H} 9 \mathrm{c} 2$ myotubes. Although fatty acids are able to upregulate the expression of FAT/CD36 and H-FABP over two-fold in neonatal cardiomyocytes, they failed to induce the expression of these fatty acid transport proteins in $\mathrm{H} 9 \mathrm{c} 2$ cells (data not shown).

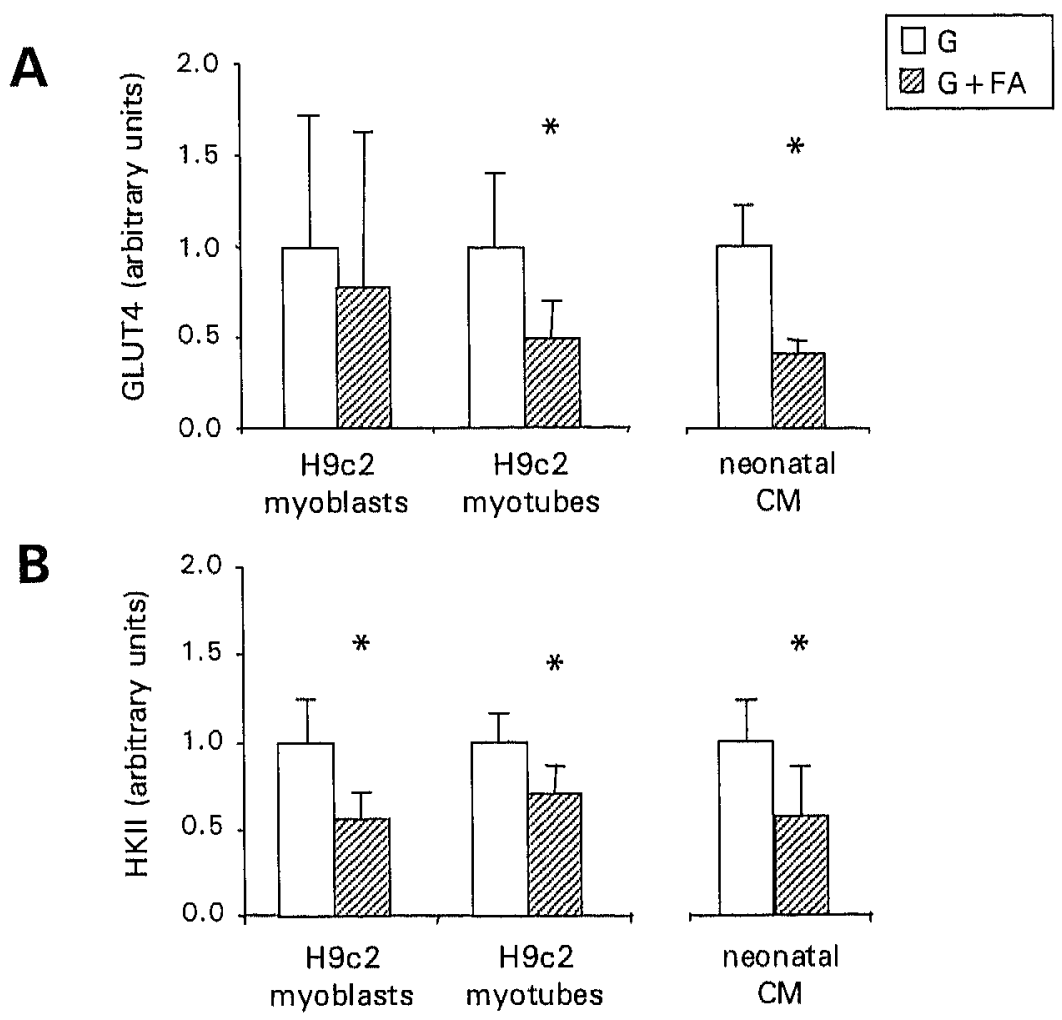

Figure 4.3 Effects of fatty acids on (A) GLUT4 and (B) hexokinase II (HKII) gene expression in H9c2 myoblasts and myotubes, and neonatal rat cardiomyocytes $(\mathrm{CM})$. Cells were exposed to either glucose $(G)$ or a combination of glucose and fatty acids $(G+F A$; palmitic and oleic acid) for $48 \mathrm{~h}$. The expression levels after exposure to both glucose and fatty acids relative to levels after exposure to glucose only (arbitrarily set at 1.0) are shown. mRNA levels were first normalised to the corresponding $18 \mathrm{~S}$ ribosomal signal to correct for differences in loading. Data are presented as means $\pm S D$ ( $n \geq 5$ from at least four independent experiments). * indicates significantly different $(p<0.05)$ from glucose group. 
A
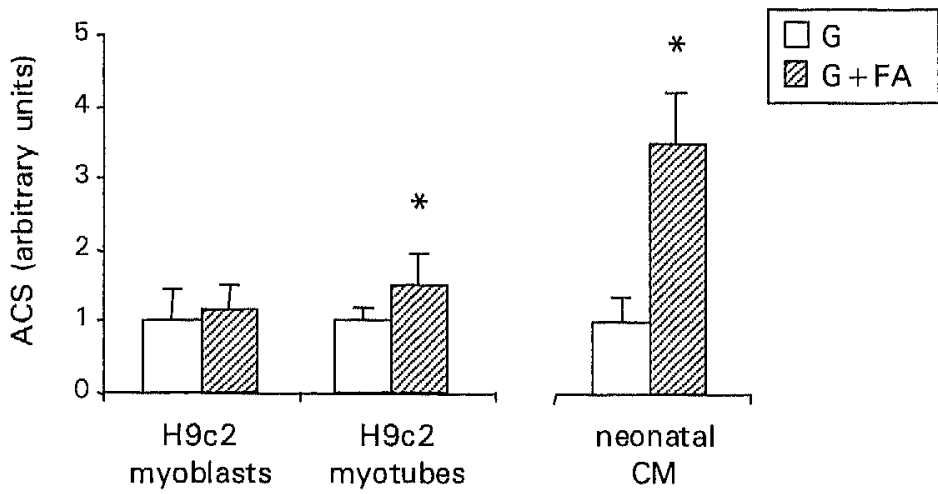

B
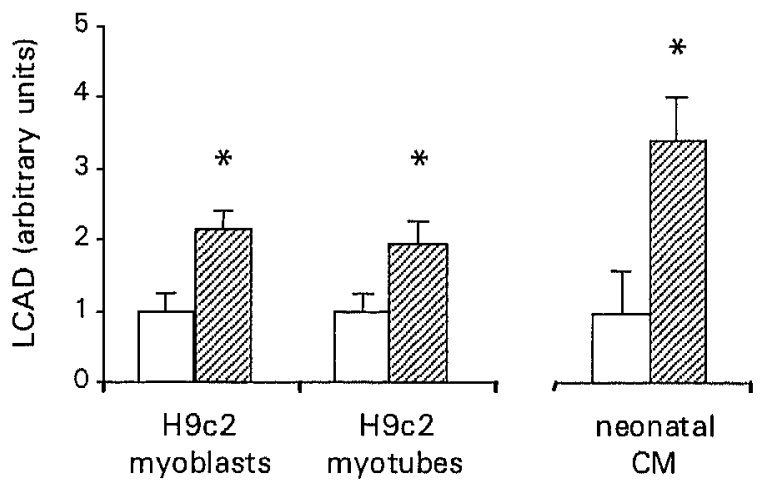

C
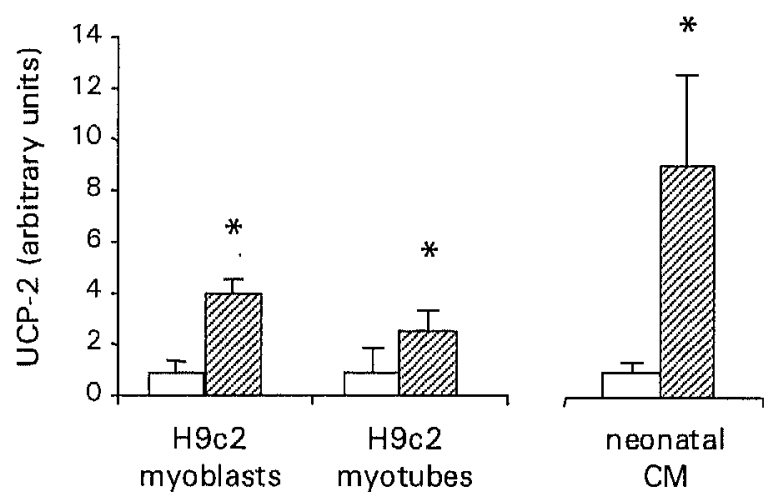

Figure 4.4 Effects of fatty acids on the expression of (A) acyl-CoA synthetase (ACS), (B) long-chain acyl-COA dehydrogenase (LCAD), and (C) the uncoupling protein UCP-2 in $\mathrm{H} 9 \mathrm{c} 2$ myoblasts and myotubes, and neonatal rat cardiomyocytes $(C M)$. Cells were exposed to either glucose $(G)$ or a combination of glucose and fatty acids ( $G+F A$; palmitic and oleic acid) for 48 h. The expression levels after exposure to both glucose and fatty acids relative to levels after exposure to glucose only (arbitrarily set at 1.0) are shown. mRNA levels were first normalised to the corresponding $18 \mathrm{~S}$ ribosomal signal to correct for differences in loading. Data are presented as means $\pm S D(n \geq 5$ from at least three independent experiments). * indicates significantly different $(p<0.05)$ from glucose group. 


\section{PPAR-isoform expression}

Overall, the data described above indicate that the effects of fatty acids on gene expression are more pronounced in cardiac myocytes than in $\mathrm{H} 9 \mathrm{c} 2$ cells. As we and others $[12,38]$ have previously demonstrated that the effects of fatty acids on cardiac myocytes are likely to be PPAR-mediated, the role of PPARs was further explored. First, the expression of PPAR-isoforms was examined in the different cell types and in the adult rat heart. Neither in $\mathrm{H} 9 \mathrm{C} 2$ cells nor in neonatal cardiomyocytes PPAR $\gamma$ mRNA could be detected (Fig. 4.5). In the adult heart PPAR $\gamma$ was expressed at a very low level. In H9c2 myoblasts and myotubes as well as in cardiac myocytes and adult tissue PPAR $\beta / \delta$ mRNA was present. However, PPAR $\alpha$ expression was restricted to neonatal cardiac myocytes and adult cardiac tissue (Fig. 4.5). The latter finding prompted us to investigate whether the difference in response to fatty acids between $\mathrm{H} 9 \mathrm{C} 2$ cells and cardiac myocytes was related to differences in PPAR-isoform expression.

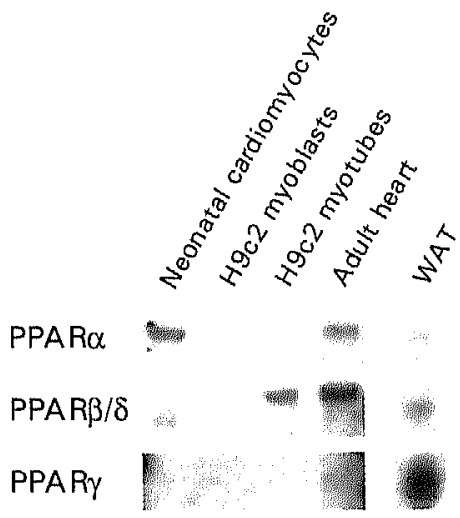

Figure 4.5 Northern blots showing the distribution of PPAR $\alpha$ and PPAR $\beta / \delta$ mRNA in neonatal rat cardiomyocytes, $\mathrm{H} 9 \mathrm{C} 2$ myoblasts, $\mathrm{H} 9 \mathrm{c} 2$ myotubes, and in adult rat heart. White adipose tissue (WAT) is included as a positive control for PPAR $\gamma$.

\section{Effects of isoform-specific PPAR agonists}

To assess the role of each of the PPAR-isoforms as putative mediators in fatty acidinduced gene expression, the different cell types were treated with Wy-14,643, L165041 and ciglitazone, specific agonists for PPAR $\alpha$, PPAR $\beta / \delta$ and PPAR $\gamma$, respectively. At concentrations of $10 \mu \mathrm{M}$ these PPAR agonists were previously shown to be effective and isoform-specific in other cell types $[8,44,45]$. As anticipated, the PPAR agonist ciglitazone was unable to induce any of the genes investigated in both $\mathrm{H} 9 \mathrm{C} 2$ cells and cardiac myocytes (Figs. 4.6 and 4.7). In line with the cellular distribution of PPAR $\alpha$, its ligand Wy-14,643 markedly induced the expression of ACS, LCAD and UCP-2 in neonatal cardiac myocytes (Fig. 4.6). In contrast, Wy-14,643 was 
ineffective in $\mathrm{H} 9 \mathrm{c} 2$ cells (Fig. 4.7). In neonatal cardiomyocytes, the addition of the PPAR $/ \delta$ ligand L-165041 led to a marked increase in UCP-2 expression, but the rise in ACS and LCAD mRNA levels did not reach the level of significance (Fig. 4.6). In $\mathrm{H} 9 \mathrm{c} 2$ cells, the PPAR $\beta / \delta$ agonist increased mRNA levels of both ACS and LCAD to the same degree as fatty acids did (Fig. 4.7). The expression of genes involved in glucose uptake and metabolism, GLUT4 and HKII, respectively, was not affected by PPAR ligands in $\mathrm{H} 9 \mathrm{c} 2$ cells. Interestingly, UCP-2 mRNA levels were clearly upregulated by fatty acids and L-165041 in H9C2 myoblasts, but not in myotubes. Conversely, while mRNA of the uncoupling protein-isoform UCP-3 could not be detected in H9c2 myoblasts, in $\mathrm{H} 9 \mathrm{C} 2$ myotubes UCP-3 expression was markedly induced by both fatty acids and the PPAR $\beta / \delta$ agonist (Fig. 4.7).
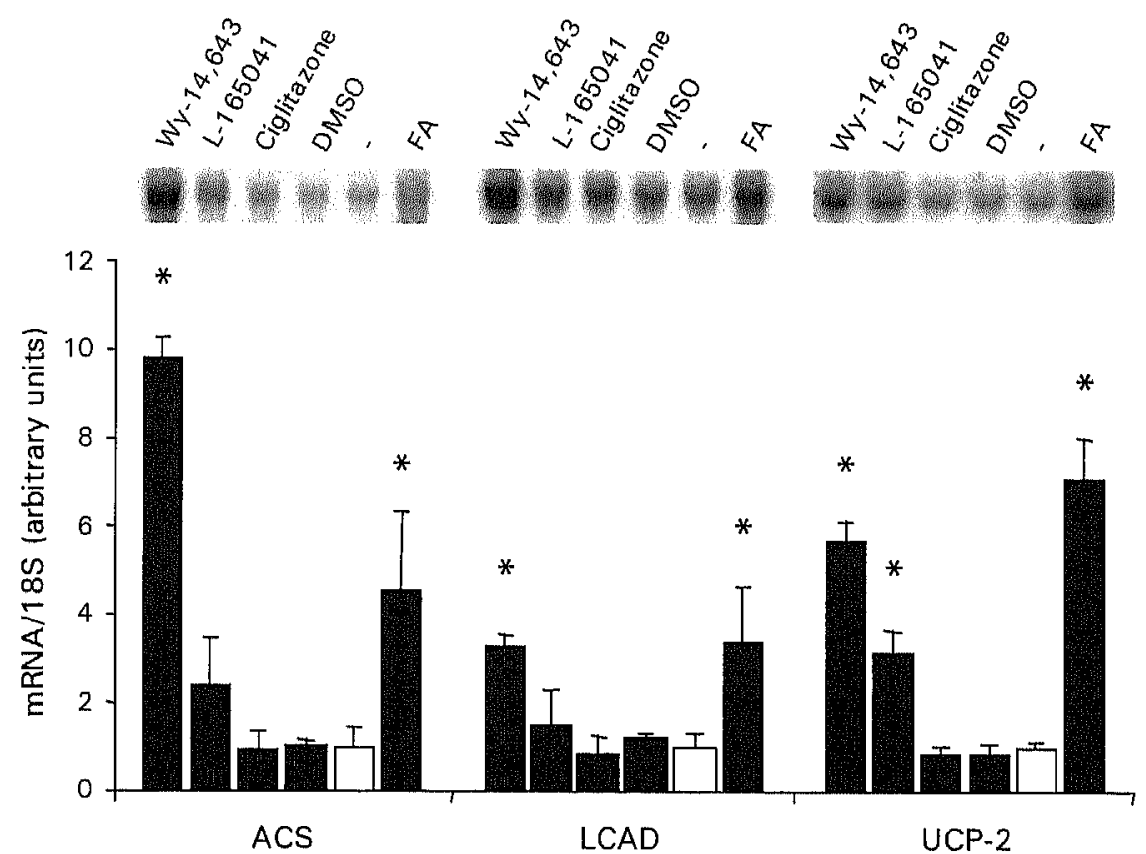

Figure 4.6 Effects of $W y-14,643, L-165041$, and ciglitazone, specific ligands for PPAR $\alpha$, PPAR $\beta / \delta$, and PPAR $\gamma$, respectively, on gene expression of the glucose transporter GLUT4, hexokinase II (HKII), acyl-CoA synthetase (ACS), long-chain acyl-CoA dehydrogenase (LCAD), and the uncoupling protein $U C P-2$ in neonatal rat cardiomyocytes. Cells were exposed to medium containing glucose as the only substrate without $(-)$ or with $10 \mu \mathrm{M}$ ligand, DMSO (vehicle), or fatty acids (FA), for $48 \mathrm{~h}$. Representative northern blot signals of the mRNAs investigated are included. Following normalisation of the mRNA levels to the corresponding $18 \mathrm{~S}$ ribosomal signal, the level of expression of the control group $(-)$ was arbitrarily set at 1.0 . Data are presented as means \pm SD from three independent experiments. * indicates significantly different $(p<0.05)$ from control group. 
translocase FAT/CD36 and the cytosolic heart-type fatty acid-binding H-FABP, fatty acid-transporting proteins that are both abundantly expressed in skeletal and cardiac muscle cells, are absent in $\mathrm{H} 9 \mathrm{c} 2$ myoblasts $[31,41]$. In contrast to the mouse skeletal muscle-derived cell line $\mathrm{C} 2 \mathrm{C} 12$ [32], the expression of $\mathrm{H}-\mathrm{FABP}$ could not be induced by differentiation in $\mathrm{H} 9 \mathrm{C} 2$ cells. Furthermore, the addition of fatty acids or PPAR ligands neither induced the expression of either one of the fatty acid-transporting proteins. In this regard, the $\mathrm{H} 9 \mathrm{c} 2$ cells clearly differ from neonatal cardiac myocytes.

Interestingly, the expression of glucose (GLUT4, HKII) and fatty acid (ACS, LCAD) metabolic genes was higher in $\mathrm{H} 9 \mathrm{C} 2$ myotubes than in myoblasts, indicating that the increased oxidation rate of fatty acids as found during H9c2 cell differentiation [24] may have its origin in an enhanced expression of metabolic genes. Generally speaking, fatty acids induced the expression of genes coding for proteins involved in cardiac fatty acid metabolism in both neonatal cardiomyocytes and $\mathrm{H} 9 \mathrm{c} 2$ cells, although the changes were less pronounced in the $\mathrm{H} 9 \mathrm{c} 2$ cell line. This may be explained by differences in the PPAR isoform distribution (see below).

\section{Involvement of PPARs}

Peroxisome proliferator-activated receptors (PPARs) play a regulatory role in lipid metabolism, since they are able to modify the expression of many genes involved in extracellular as well as intracellular lipid metabolism [15,18,34]. Fatty acids can act as natural ligands to activate these transcription factors $[16,19,21,22,27]$. Therefore, PPARs are likely candidates for a role in the fatty acid-induced changes in metabolic gene expression in the heart.

Three PPAR-isoforms exist, designated PPAR $\alpha, P P A R \beta / \delta$ and PPAR $\gamma$, but convincing evidence on the presence of these PPAR-isoforms in the heart came only for PPAR $\alpha$ and PPAR $\beta / \delta[1,26,29]$. In literature, conflicting results have been reported regarding the expression of PPAR $\gamma$ in the heart. PPAR $\gamma$ mRNA was either detected at low levels in cardiac tissue $[2,26,46]$ or did not reach the level of detection at all $[10,23]$. In the present study, mRNA of PPAR $\gamma$ appeared to be undetectable in neonatal rat cardiomyocytes but was shown to be slightly expressed in the adult heart. Therefore, it is feasible that PPAR $\gamma$ is expressed in the heart by non-muscle cells only, providing an explanation for the contradictory results. However, a recent study of Takano et al. [35] demonstrated the presence of both PPAR $\gamma$ mRNA and protein in neonatal rat cardiomyocytes, keeping up the controversy. As far as the possible role of PPAR $\gamma$ in the heart is concerned, it has been suggested that PPAR $\gamma$ may be involved in the improvement of insulin action, since treatment of adult ventricular myocytes with thiazolidinediones, known PPAR $\gamma$ activators, resulted in an increased protein content of the glucose transporters GLUT1 and GLUT4 and a rise in glucose uptake [3]. Here, we demonstrated that neither in neonatal cardiomyocytes nor in $\mathrm{H} 9 \mathrm{c} 2$ cells PPARr plays a role in the regulation of the expression of genes coding for proteins concerned with the metabolism of fatty acids, since the PPAR $\gamma$ ligand ciglitazone was not able to alter the expression of these genes, even when applied at higher concentrations (up to $100 \mu \mathrm{M}$; data not shown). 
In contrast to the adult heart and neonatal cardiomyocytes, mRNA of the PPAR isoform PPAR $\alpha$ could not be detected in the embryonic rat heart-derived H9c2 cell line. It is tempting to speculate that this difference may have its origin in the source of cells. In developing rat embryos cardiac PPAR $\alpha$ mRNA was only transiently expressed from day thirteen to fifteen [11]. In contrast, PPAR $\beta / \delta$ was expressed in the heart from embryonic day 13.5 onward [11] and, as presently demonstrated, in both H9c2 myoblasts and myotubes and neonatal cardiomyocytes as well as in the adult heart.

In the heart, PPAR $\alpha$ has been shown to be involved in the regulation of the expression of genes coding for proteins involved in fatty acid metabolism [28,38,43]. The present study corroborates these findings. Recently, several studies provided indications for a role for PPAR $\beta / \delta$ in cellular lipid metabolism as well. In reaggregated brain cell cultures the PPAR $\beta / \delta$-specific ligand L-165041 increased gene transcription of the acyl-COA synthetase isoform ACS2 [6]. In addition, it has been suggested that PPAR $\beta / \delta$ plays a role in the regulation of adipogenesis $[4,5]$. The present data indicate that specific activation of PPAR $\beta / \delta$, compared to PPAR $\alpha$, results in a minor effect on neonatal cardiomyocyte gene expression, but consistently increases mRNA levels of proteins involved in intracellular fatty acid metabolism in $\mathrm{H} 9 \mathrm{c} 2$ cells, thereby mimicking the effects of fatty acids. This effect was most obvious for the uncoupling proteins UCP-2 and UCP-3, the former being induced by both fatty acids and L165041 in $\mathrm{H} 9 \mathrm{c} 2$ myoblasts, and the latter in $\mathrm{H} 9 \mathrm{c} 2$ myotubes. It appears that PPAR $\beta / \delta$ is able to regulate metabolic gene expression, an effect that becomes manifest particularly in the absence of PPAR $\alpha$, i.e. in $\mathrm{H} 9 \mathrm{c} 2$ cells, suggesting redundant roles of PPAR $\alpha$ and PPAR $\beta / \delta$ in the regulation of cardiac fatty acid metabolism. Indeed, administration of PPAR $\gamma$ and/or PPAR $\beta / \delta$ agonists at high doses to PPAR $\alpha$ null mice induced peroxisome proliferation in liver [14], a phenomenon formerly exclusively ascribed to PPAR $\alpha$. It would be interesting to investigate whether introduction of PPAR $\alpha$ into $H 9 c 2$ cells alters the responsiveness of these cells to fatty acids and specific PPAR $\beta / \delta$ ligands.

Together, the present findings indicate that PPAR $\gamma$ is not likely to play a role in the regulation of metabolic gene expression in heart muscle cells, and assign PPAR $\alpha$ as the most important PPAR-isoform in cardiac metabolic gene regulation. Nonetheless, $\operatorname{PPAR} \beta / \delta$ was also shown to be able to regulate fatty acid metabolic genes, hence warranting further investigation of this receptor in the regulation of cardiac fatty acid metabolism. In this respect, $\mathrm{H} 9 \mathrm{c} 2$ cells, lacking PPAR $\alpha$, may provide a useful in vitro model system.

\section{References}

1. Amri E-Z, Bonino F, Ailhaud G, Abumrad NA, and Grimaldi PA (1995). Cloning of a protein that mediates transcriptional effects of fatty acids in preadipocytes. Homology to peroxisome proliferator-activated receptors. / Biol Chem 270, 2367-2371

2. Aperlo C, Pognonec P, Saladin R, Auwerx J, and Boulukos KE (1995). cDNA cloning and characterization of the transcriptional activities of the hamster peroxisome proliferatoractivated receptor haPPARy. Gene 162, 297-302 
3. Bähr $M$, Spelleken $M$, Bock $M$, von Holtey $M$, Kiehn R, and Eckel J (1996). Acute and chronic effects of troglitazone (CS-045) on isolated rat ventricular cardiomyocytes. Diabetologia 39, 766-774

4. Bastie C, Holst D, Gaillard D, JehI-Pietri C, and Grimaldi PA (1999). Expression of peroxisome proliferator-activated receptor PPARS promotes induction of PPAR $\gamma$ and adipocyte differentiation in 3T3C2 fibroblasts. / Biol Chem 274, 21920-21925

5. Bastie C, Luquet S, Holst D, Jehl-Pietri C, and Grimaldi PA (2000). Alterations of peroxisome proliferator-activated receptor $\delta$ activity affect fatty acid-controlled adipose differentiation. I Biol Chem 275, 38768-38773

6. Basu-Modak S, Braissant O, Escher P, Desvergne B, Honegger $P$, and Wahli W (1999). Peroxisome proliferator-activated receptor $\beta$ regulates acyl-CoA synthetase 2 in reaggregated rat brain cell cultures. I Biol Chem 274, 35881-35888

7. Bengel FM, Anton M, Avril N, Brill T, Nguyen N, Haubner R, Gleiter E, Gansbacher B, and Schwaiger $M$ (2000). Uptake of radiolabeled 2'-fluoro-2'-deoxy-5-iodo-1-beta-Darabinofuranosyluracil in cardiac cells after adenoviral transfer of the herpesvirus thymidine kinase gene: the cellular basis for cardiac gene imaging. Circulation 102, 948-950

8. Berger J, Leibowitz MD, Doebber TW, Elbrecht A, Zhang B, Zhou G, Biswas C, Cullinan CA, Hayes NS, Li Y, Tanen M, Ventre J, Wu MS, Berger GD, Mosley R, Marquis R, Santini C, Sahoo SP, Tolman RL, Smith RG, and Moller DE (1999). Novel peroxisome proliferatoractivated receptor (PPAR) $\gamma$ and PPAR $\delta$ ligands produce distinct biological effects. / Biol Chem 274, 6718-6725

9. Bowes J, McDonald MC, Piper J, and Thiemermann C (1999). Inhibitors of poly (ADP-ribose) synthetase protect rat cardiomyocytes against oxidant stress. Cardiovasc Res 41, 126-134

10. Braissant O, Foufelle $F$, Scotto C, Dauça $M$, and Wahli W (1996). Differential expression of peroxisome proliferator-activated receptors (PPARs): tissue distribution of PPAR- $\alpha,-\beta$, and $-\gamma$ in the adult rat. Endocrinology 137, 354-366

11. Braissant $O$ and $W$ ahli $W$ (1998). Differential expression of peroxisome proliferator-activated receptor- $\alpha,-\beta$, and $-\gamma$ during rat embryonic development. Endocrinology $139,2748-2754$

12. Brandt JM, Djouadi F, and Kelly DP (1998). Fatty acids activate transcription of the muscle carnitine palmitoyltransferase I gene in cardiac myocytes via the peroxisome proliferatoractivated receptor $\alpha$. / Biol Chem 273, 23786-23792

13. De Vries JE, Vork MM, Roemen THM, de Jong YF, Cleutjens JPM, van der Vusse GJ, and van Bilsen $M$ (1997). Saturated but not mono-unsaturated fatty acids induce apoptotic cell death in neonatal rat ventricular myocytes. J Lipid Res 38, 1384-1394

14. DeLuca JG, Doebber TW, Kelly LJ, Kemp RK, Molon-Noblot S, Sahoo SP, Ventre J, Wu MS, Peters JM, Gonzalez FJ, and Moller DE (2000). Evidence for peroxisome proliferator-activated receptor (PPAR) $\alpha$-independent peroxisome proliferation: effects of PPAR $\gamma / \delta$-specific agonists in PPARo-null mice. Mol Pharmacol 58, 470-476

15. Desvergne B and Wahli W (1999). Peroxisome proliferator-activated receptors: nuclear control of metabolism. Endocr Rev 20, 649-688

16. Forman BM, Chen J, and Evans RM (1997). Hypolipidemic drugs, polyunsaturated fatty acids, and eicosanoids are ligands for peroxisome proliferator-activated receptors $\alpha$ and $\delta$. Proc Natl Acad Sci USA 94, 4312-4317

17. Gerrelli D, Huntriss JD, and Latchman DS (1994). Antagonistic effects of retinoic acid and thyroid hormone on the expression of the tissue-specific splicing protein $\mathrm{SmN}$ in a clonal cell line derived from rat heart. / Mol Cell Cardiol 26, 713-719

18. Gervois P, Torra IP, Fruchart JC, and Staels B (2000). Regulation of lipid and lipoprotein metabolism by PPAR activators. Clin Chem Lab Med 38, 3-11

19. Göttlicher M, Widmark E, Li Q, and Gustafsson J-A (1992). Fatty acids activate a chimera of the clofibric acid-activated receptor and the glucocorticoid receptor. Proc Nat/ Acad Sci USA 89, 4653-4657 
20. Hescheler J, Meyer R, Plant S, Krautwurst D, Rosenthal W, and Schultz G (1991). Morphological, biochemical, and electrophysiological characterization of a clonal cell (H9c2) line from rat heart. Circ Res 69, 1476-1486

21. Issemann I, Prince RA, Tugwood JD, and Green S (1993). The peroxisome proliferatoractivated receptor:retinoid $X$ receptor heterodimer is activated by fatty acids and fibrate hypolipidaemic drugs. / Mol Endocrinol 11, 37-47

22. Johnson TE, Holloway MK, Vogel R, Rutledge SJ, Perkins J], Rodan GA, and Schmidt A (1997). Structural requirements and cell-type specificity for ligand activation of peroxisome proliferator-activated receptors. / Steroid Biochem Molec Biol 63, 1-8

23. Jones PS, Savory R, Barratt P, Bell AR, Gray TJB, Jenkins NA, Gilbert DJ, Copeland NG, and Bell DR (1995). Chormosomal localisation, inducibility, tissue-specific expression and strain differences in three murine peroxisome-proliferator-activated-receptor genes. Eur / Biochem 233, 219-226

24. Kim JM, Yoon M, Kang I, Kim SS, and $\mathrm{Ha} J$ (1998). Evidence that acetyl-CoA carboxylase isoforms play different biological roles in $\mathrm{H} 9 \mathrm{c} 2$ cardiomyocyte. Biochem Biophys Res Commun 248, 490-496

25. Kimes BW and Brandt BL (1976). Properties of a clonal muscle cell line from rat heart. Exp Cell Res 98, 376-381

26. Kliewer SA, Forman BM, Blumberg B, Ong ES, Borgmeyer U, Mangelsdorf DJ, Umesono K, and Evans RM (1994). Differential expression and activation of a family of murine peroxisome proliferator-activated receptors. Proc Natl Acad Sci USA 91, 7355-7359

27. Kliewer SA, Sundseth SS, Jones SA, Brown PJ, Wisely GB, Koble CS, Devchand P, Wahli W, Willson TM, Lenhard JM, and Lehmann JM (1997). Fatty acids and eicosanoids regulate gene expression through direct interactions with peroxisome proliferator-activated receptors $\alpha$ and \%. Proc Natl Acad Sci USA 94, 4318-4323

28. Leone TC, Weinheimer Cl, and Kelly DP (1999). A critical role for the peroxisome proliferatoractivated receptor $\alpha(P P A R \alpha)$ in the cellular fasting response: The PPAR $\alpha$-null mouse as a model of fatty acid oxidation disorders. Proc Natl Acad Sci USA 96, 7473-7478

29. Mukherjee R, Jow L, Noonan D, and McDonnell DP (1994). Human and rat peroxisome proliferator activated receptors (PPARs) demonstrate similar tissue distribution but different responsiveness to PPAR activators. / Steroid Biochem Molec Biol 51, 157-166

30. Pediconi MF, Politi LE, Bouzat CB, De Los Santos EB, and Barrantes F) (1992). Myogenic differentiation of the muscle clonal cell line $\mathrm{BC} 3 \mathrm{H}-1$ is accompanied by changes in its lipid composition. Lipids 27, 669-675

31. Pelsers MMAL, Lutgerink JT, van Nieuwenhoven FA, Tandon NN, van der Vusse GJ, Arends JW, Hoogenboom HR, and Glatz JFC (1999). A sensitive immunoassay for rat fatty acid translocase (CD36) using phage antibodies selected on cell transfectants: abundant presence of fatty acid translocase/CD36 in cardiac and red skeletal muscle and up-regulation in diabetes. Biochem / 337, 407-414

32. Rump R, Buhlmann C, Börchers $T$, and Spener F (1996). Differentiation-dependent expression of heart type fatty acid-binding protein in C2C12 muscle cells. Eur / Cell Biol 69, 135-142

33. Sauro VS and Strickland KP (1987). Changes in oleic acid oxidation and incorporation into lipids of differentiating $\mathrm{L} 6$ myoblasts cultured in normal or fatty acid-supplemented growth medium, Biochem / 244, 743-748

34. Schoonjans K, Staels B, and Auwerx J (1996). The peroxisome proliferator activated receptors (PPARs) and their effects on lipid metabolism and adipocyte differentiation. Biochim Biophys Acta 1302, 93-109

35. Takano H, Nagai T, Asakawa M, Toyozaki T, Oka T, Komuro I, Saito T, and Masuda Y (2000). Peroxisome proliferator-activated receptor activators inhibit lipopolysaccharide-induced tumor necrosis factor- $\alpha$ expression in neonatal rat cardiac myocytes. Circ Res $87,596-602$ 
36. Van Bilsen $M$, de Vries JE, and van der Vusse G) (1997). Long-term effects of fatty acids on cell viability and gene expression of neonatal cardiac myocytes. Prostaglandins Leukot Essent Fatty Acids 57, 30-45

37. Van Bilsen $M$, van der Vusse GJ, and Reneman RS (1998). Transcriptional regulation of metabolic processes: implications for cardiac metabolism. Eur / Physiol 437, 2-14

38. Van der Lee KAJM, Vork MM, de Vries JE, Willemsen PHM, Glatz JFC, Reneman RS, van der Vusse Gl, and van Bilsen $M(2000)$. Long-chain fatty acid-induced changes in gene expression in neonatal cardiac myocytes. / Lipid Res 41, 41-47

39. Van der Lee KAJM, Willemsen PHM, van der Vusse GJ, and van Bilsen M (1999). Modulation of gene expression by fatty acids in non-differentiated and differentiated cardiac-derived $\mathrm{H} 9 \mathrm{C} 2$ cells. Abstract. / Mol Cell Cardiol 31, A69

40. Van der Lee KAJM, Willemsen PHM, van der Vusse GJ, and van Bilsen $M(2000)$. Effects of fatty acids on uncoupling protein-2 expression in the rat heart. FASEB / 14, 495-502

41. Van Nieuwenhoven FA, Willemsen PHM, van der Vusse GJ, and Glatz JFC (1999). Coexpression in rat heart and skeletal muscle of four genes coding for proteins implicated in long-chain fatty acid uptake. Int / Biochem Cell Biol 31, 489-498

42. Wallenstein S, Zucker CL, and Fleiss JL (1980). Some statistical methods useful in circulation research. Circ Res 47, 1-9

43. Watanabe K, Fujii H, Takahashi T, Kodama M, Aizawa Y, Ohta Y, Ono T, Hasegawa G, Naito $M$, Nakajima T, Kamijo Y, Gonzalez FJ, and Aoyama T (2000). Constitutive regulation of cardiac fatty acid metabolism through peroxisome proliferator-activated receptor $\alpha$ associated with age-dependent cardiac toxicity. I Biol Chem 275, 22293-22299

44. Willson TM, Cobb JE, Cowan DJ, Wiethe RW, Correa ID, Prakash SR, Beck KD, Moore LB, Kliewer SA, and Lehmann JM (1996). The structure-activity relationship between peroxisome proliferator-activated receptor $\gamma$ agonism and the antihyperglycemic activity of thiazolidinediones. / Med Chem 39, 665-668

45. Yu K, Bayona W, Kallen CB, Harding HP, Ravera CP, McMahon G, Brown M, and Lazar MA (1995). Differential activation of peroxisome proliferator-activated receptors by eicosanoids. I Biol Chem 270, 23957-23983

46. Zhu Y, Alvares K, Huang Q, Rao MS, and Reddy JK (1993). Cloning of a new member of the peroxisome proliferator-activated receptor gene family from mouse liver. I Biol Chem 268, $26817-26820$ 


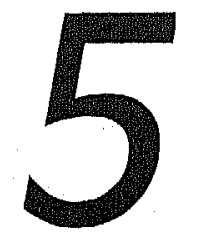

\section{Effects of fatty acids on uncoupling protein-2 expression in the rat heart}

Karin AJM van der Lee, Peter HM Willemsen, Ger J van der Vusse, and Marc van Bilsen

Department of Physiology, Cardiovascular Research Institute Maastricht, Maastricht University, the Netherlands

FASEB J 14, 495-502 (2000) 


\begin{abstract}
Fatty acids are thought to play a role in the activity of uncoupling proteins (UCP) and have been shown to regulate the expression of genes encoding proteins involved in fatty acid handling. Therefore, we investigated whether fatty acids, which are the main substrates for the heart, affect rat cardiac UCP-2 expression in vivo and in vitro. After birth, when the contribution of fatty acid oxidation to cardiac energy conversion increases, UCP-2 expression enhanced rapidly. In the adult heart, however, UCP-2 $m R N A$ levels did not alter during conditions which are associated with either enhanced (fasting, diabetes) or decreased (hypertrophy) fatty acid utilisation. Exposure of neonatal cardiomyocytes and embryonic rat heart-derived $\mathrm{H} 9 \mathrm{c} 2 \mathrm{cells}$ to fatty acids (palmitic and oleic acid) for 48 h, strongly induced UCP-2 expression. Stimulation of neonatal cardiomyocytes with triiodothyronine also increased UCP-2 mRNA levels, though only in the presence of fatty acids. Ligands specific to the fatty acid-activated transcription factor PPAR $\alpha$, but not to PPAR $\gamma$, acted as inducers of cardiomyocyte UCP-2 expression. It is concluded that fatty acids promote UCP-2 expression in neonatal cardiomyocytes, which might explain the rapid increase in UCP-2 mRNA in the postnatal heart. However, UCP-2 mRNA levels in the adult heart appear to be insensitive to changes in cardiac fatty acid handling under various pathological conditions.
\end{abstract}

\title{
Introduction
}

Besides being the main source of energy for the heart, fatty acids were also found to act as uncouplers of oxidative phosphorylation. Pioneering studies by Challoner and Steinberg [10] have shown that fatty acids increase cardiac oxygen consumption for the same amount of external work, when applied to the isolated perfused rat heart. This indicates uncoupling of mitochondrial respiratory chain activity and ATP production. Later studies demonstrated progressive uncoupling in heart mitochondria when rats were fed a lipid-enriched diet [2].

The uncoupling protein (UCP) is known to uncouple oxidative phosphorylation by moving protons across the mitochondrial inner membrane towards the mitochondrial matrix (reviewed in [33]). Whereas the first uncoupling protein (UCP-1) was already reported two decades ago, two other members of the family, i.e. UCP-2 and -3 , have recently been cloned $[4,14,47]$. UCP-3 is mainly expressed in brown adipose tissue and skeletal muscle, while UCP-2 is more ubiquitously distributed. Since expression of UCP-2 is relatively high in heart tissue $[4,14]$, it is feasible that UCP-2 mediates the fatty acid-induced uncoupling effects observed in this organ. Indeed, fatty acids have been demonstrated to enhance the uncoupling activity of UCP [50]. Therefore, we propose a close functional relationship between fatty acid handling and uncoupling proteins in cardiac tissue. 
Recently we demonstrated in neonatal cardiomyocytes, that fatty acids regulate the expression of genes encoding proteins involved in fatty acid transport and metabolism [43]. Other studies suggested that fatty acids may also be implicated in the regulation of UCP-2 expression. For instance, skeletal muscle UCP-2 mRNA levels in rat and human were found to increase during fasting, a condition which is associated with a rise in plasma fatty acid levels $[3,31,36]$. Subsequent refeeding of rats resulted in a decline in plasma fatty acid levels and a concomitant decrease in skeletal muscle UCP-2 expression [36].

The first aim of the present study was to investigate whether cardiac UCP-2 mRNA levels change during heart development and under (patho-)physiological conditions associated with changes in fatty acid utilisation in the adult heart, i.e. fasting, diabetes and cardiac hypertrophy. Second, it was determined whether UCP-2 expression is upregulated in cultured neonatal cardiomyocytes and embryonic rat heart-derived $\mathrm{H} 9 \mathrm{c} 2$ cells, after exposure to fatty acids and/or following stimulation with the $\alpha_{1-}$ adrenergic agonist phenylephrine or the thyroid hormone triiodothyronine (T3). Finally, the possible involvement of peroxisome proliferator-activated receptors (PPARs), transcription factors known to be activated by fatty acids [15,22], in neonatal cardiomyocyte UCP-2 expression was explored.

\section{Materials and methods}

\section{Animal experiments}

Animals were fed ad libitum (Diet SRIVI-A, Hope Farms, Woerden, the Netherlands), had free access to water, and were kept under an artificial dark-light cycle of $12 \mathrm{~h}$. The experiments were approved by the Institutional Animal Care and User Committee of the Maastricht University.

Heart, soleus, extensor digitorum longus (EDL), and gastrocnemius muscles were dissected from adult (10 weeks old) Wistar Kyoto rats. Hearts were also obtained at birth (day 0 ) and at 2, 6 and 21 days. Hearts from foetal rats were obtained by sacrificing pregnant rats, at day 21 of pregnancy (day -1 ).

Insulin-dependent diabetes was evoked in 3 months old male Wistar rats (Winkelmann, Borchen, FRG) by a single i.v. injection of streptozotocin $(55 \mathrm{mg} / \mathrm{kg}$ body weight) as described elsewhere [13]. Rats were sacrificed after three weeks, when body weight had decreased by $27 \%$ and plasma glucose levels had increased from $7.0 \pm 0.7 \mathrm{mM}$ to $22.5 \pm 2.7 \mathrm{mM}$ [13].

Cardiac hypertrophy was induced by suprarenal aorta banding as previously described [40]. After anaesthetisation of 6-7 weeks old male Lewis rats with pentobarbital $(0.06 \mathrm{mg} / \mathrm{g}$ body weight i.p.), a lateral abdominal incision was made. In the experimental group, a ligature was tightened suprarenally around the abdominal aorta. In sham-operated animals the aorta was only dissected free. The abdomen was closed and the rats were allowed to recover. After four weeks animals were sacrificed and mean heart to body weight ratio had increased by $24 \%$. 
Hearts of 6 weeks old male Sprague-Dawley rats, either fasted for $46 \mathrm{~h}$ or fed ad libitum, were a generous gift of Dr. S. Samec and Dr. A. Dulloo, University of Geneva, Switzerland. In the serum of fasted rats fatty acid levels had increased threefold $(1.33 \pm 0.25 \mathrm{mM}$ versus $0.45 \pm 0.13 \mathrm{mM})$ at the time of sacrifice [35].

Rats subjected to the different treatments were killed by cervical dislocation, except rats previously subjected to sham or aorta banding operations in which hearts were excised following anaesthesia with pentobarbital $(0.06 \mathrm{mg} / \mathrm{g}$ body weight i.p.). After excision, tissues were immediately frozen in liquid nitrogen and stored at $-80^{\circ} \mathrm{C}$ until further analysis.

\section{Cell culture}

Primary cultures of ventricular myocytes from 0-3 days old neonatal rats were prepared as described previously [12]. Cardiomyocytes were plated at low density $\left(40,000\right.$ cells $\left./ \mathrm{cm}^{2}\right)$ in tissue culture dishes coated with $1 \%$ gelatine type B (Sigma, St. Louis MO, USA) in a 4:1 mixture of DMEM (Gibco-BRL Life Technologies, Gaithersburg MD, USA) and M199 (Gibco) supplemented with 10\% horse serum (Gibco), 5\% newborn calf serum (Sera-Lab, Sussex, UK), and antibiotics (P/S; penicillin $100 \mathrm{IU} / \mathrm{ml}$ and streptomycin $0.1 \mathrm{mg} / \mathrm{ml}$, Gibco). Cells were incubated overnight in this serum-rich medium.

H9c2 cells (ATCC CRL-1446; Rockville MD, USA) were maintained in a growth medium composed of DMEM supplemented with $10 \%$ foetal bovine serum (Gibco). Medium was changed every three to four days. H9c2 cells were plated at a density of 2000 cells $/ \mathrm{cm}^{2}$ and allowed to proliferate in growth medium until reaching confluence.

Experiments with neonatal cardiomyocytes as well as $\mathrm{H} 9 \mathrm{c} 2$ cells started with a 24 $h$ incubation in serum-free medium of a $4: 1$ mixture of DMEM/M199, containing $P / S$ and $10 \mathrm{mM}$ glucose as the sole substrate. Subsequently, substrate-free medium $(4: 1$ mixture of DMEM and M199 with P/S) containing $0.25 \mathrm{mM}$ L-carnitine and 0.25 $\mathrm{mU} / \mathrm{ml}$ insulin was applied to the cells. This medium was supplemented with different substrates or a combination of substrates. The first experimental group received only glucose (final concentration $10 \mathrm{mM}$ ) as substrate. Bovine serum albumin (BSA 0.15 $\mathrm{mM}$; Sigma) was also added to the medium to allow for a proper comparison between the glucose group and the experimental groups that received medium containing the fatty acid/BSA complex. The second group received a mixture of palmitic acid (C16:0) and oleic acid (C18:1) (0.25 $\mathrm{mM}$ each; complexed to $0.15 \mathrm{mM}$ BSA as described elsewhere [12]). The third group received a combination of both substrates, i.e. glucose (10 mM) and C16:0/C18:1 (0.25 mM each). Cells were harvested after $48 \mathrm{~h}$.

To induce in vitro hypertrophy, neonatal cardiac myocytes were stimulated with $10 \mu \mathrm{M}$ phenylephrine (PE; Sigma). In addition, neonatal cardiomyocytes were stimulated with $10 \mathrm{nM}$ triiodothyronine (T3; Sigma). Both agents were added to the medium $48 \mathrm{~h}$ before harvesting.

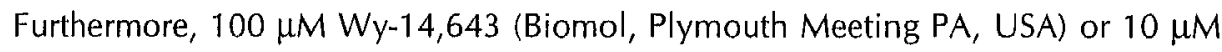
ciglitazone (Biomol), specific ligands for PPAR $\alpha$ and PPAR $\gamma$, respectively, were added to neonatal cardiomyocytes $48 \mathrm{~h}$ prior to harvesting. The cardiomyocytes were 
cultured in medium containing glucose as the sole substrate. Both compounds were dissolved in DMSO to obtain a $1000 x$ stock solution.

\section{Northern analysis}

Total RNA was isolated with TRIzol reagent (Gibco). 10 or $20 \mu \mathrm{g}$ total RNA was sizefractionated on a denaturing gel (1\% agarose, 5\% formaldehyde, 1x MOPS), transferred to a nylon membrane (Hybond-N, Amersham, Slough, UK) by capillary transfer, and fixed using standard techniques. Following prehybridisation the filters were probed with a $0.9 \mathrm{~kb}$ EcoRI-Sacl fragment of rat UCP-2 cDNA (kindly provided by Dr. D. Riquier, Centre National de la Recherche Scientifique, Meudon, France), or with a $0.5 \mathrm{~kb} \mathrm{Kpnl-BamHl}$ fragment of mouse muscle-type carnitine palmitoyl transferase 1 (mCPT1; a gift of Dr. F. van de Leij, Rijksuniversiteit Groningen, the Netherlands), or a $1.5 \mathrm{~kb}$ Xhol-Ncol fragment of rat hexokinase II (HKII; kindly provided by Dr. E. Wilson, Michigan State University, USA). The CDNA probes were labelled with $\left[\alpha_{-}{ }^{32} \mathrm{P}\right] \mathrm{dCTP}$ (3000 Ci/mmol; Amersham) by random priming (Radprime, Life Technologies) to a specific activity of $>0.5 \times 10^{9} \mathrm{cpm} / \mu \mathrm{g}$ DNA. To correct for possible differences in transfer and loading, the filters were also hybridised with ${ }^{32} \mathrm{P}$ labelled ribosomal $18 \mathrm{~S}$ probe. Following hybridisation filters were washed at the appropriate stringency to remove non-specific binding. The filters were exposed to phosphor imaging screens and subsequently scanned with a Phophorlmager (Molecular Dynamics, Sunnyvale CA, USA), and quantified using ImageQuant software (Molecular Dynamics).

\section{Protein content and cell area}

Total protein content of neonatal cardiomyocytes was quantified using the micro BCA method (Pierce, Rockford IL, USA) with BSA as standard. Cell area was assessed using Scion Image Software (http://scioncorp.com) after monitoring with a CCD camera.

\section{Statistics}

Results are presented as mean percentage of the control group $\pm S D$. Comparison between two groups was performed with a two-tailed Student's $t$-test for unpaired data. Comparison between multiple groups was performed with one-way analysis of variance (ANOVA). In case the F-ratio obtained indicated that significant differences between groups were present, the Student's t-test was carried out, applying Bonferroni's adjustment for multiple comparison [48]. Differences were considered significant at $p<0.05$.

\section{Results}

UCP-2 expression in different muscle types and during heart development

First, UCP-2 mRNA levels were determined in various striated muscle types of the rat. Figure 5.1 shows that expression of UCP-2 is relatively low in each of the skeletal 
muscle types examined, which are the fast-twitch glycolytic EDL, the slow-twitch oxidative soleus and the fast-twitch glycolytic-oxidative gastrocnemius muscles. In contrast, expression of UCP-2 in cardiac muscle far exceeds UCP-2 mRNA levels in skeletal muscle, confirming that UCP-2 is abundantly expressed in the heart.

Second, UCP-2 mRNA levels in heart tissue were determined during and after the perinatal period (Fig. 5.2). In the foetal heart, expression of UCP-2 was rather low. At birth, when plasma fatty acid levels rise and cardiac fatty acid utilisation increases [18], UCP-2 mRNA levels increased three-fold. Plateau levels were reached within three weeks thereafter. In the adult heart, UCP-2 mRNA levels were approximately four times higher than prior to birth.

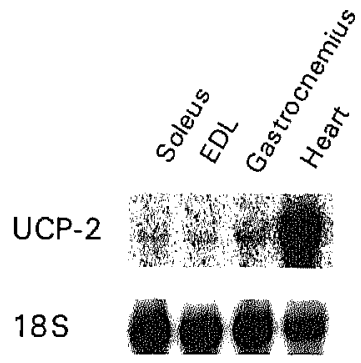

Figure 5.1 UCP-2 mRNA levels in soleus, extensor digitorum longus ( $E D L$ ), gastrocnemius and heart muscles from rat. Hybridisation signals of a representative northern blot are shown $(n=4)$. In order to visualise UCP-2 mRNA signals in skeletal muscles prolonged exposure times were required. The 185 ribosomal RNA signal is presented to demonstrate possible loading differences.

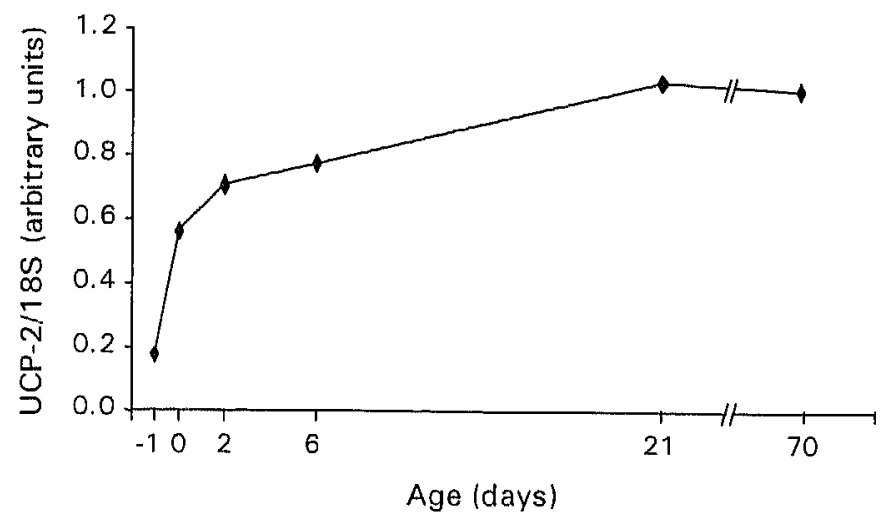

Figure 5.2 UCP-2 mRNA levels during rat heart development. The expression levels are relative to the mRNA levels at day 70 . mRNA levels were first normalised to the corresponding 185 ribosomal RNA signal to correct for possible differences in loading. 


\section{UCP-2 expression in the adult heart under (patho-)physiological conditions}

In the adult heart fatty acid utilisation changes under different (patho-)physiological conditions. Whereas cardiac fatty acid utilisation increases during fasting and diabetes $[17,25]$, it decreases during cardiac hypertrophy [20]. To examine whether these changes are accompanied with alterations in the expression of UCP-2, UCP-2 mRNA levels were determined in hearts of fasted, diabetic and aorta-banded rats. Fasting and streptozotocin-induced diabetes did not significantly alter the mRNA content of UCP2 in the rat heart (Table 5.1). Furthermore, in hypertrophied hearts of aorta-banded rats expression of UCP-2 remained unchanged compared to hearts of sham-operated animals. To ascertain that the (patho-)physiological conditions do affect the expression of genes involved in cardiac metabolism, the mRNA levels of the muscle-type carnitine palmitoyl transferase 1 (mCPT1) and hexokinase II (HKII) were also determined (Table 5.1). Indeed, mCPT1 gene expression was increased during fasting and tended to decrease during cardiac hypertrophy $(p<0.07)$, whereas the HKII mRNA levels were significantly decreased or tended to decrease in all three conditions.

\section{Fatty acid-induced expression of the UCP-2 gene in vitro}

To examine if expression of UCP-2 can be regulated by fatty acids, rat neonatal cardiomyocytes and embryonic rat heart-derived $\mathrm{H} 9 \mathrm{c} 2$ cells were used as in vitro cardiac model systems. Neonatal rat ventricular myocytes and $\mathrm{H} 9 \mathrm{c} 2$ cells were cultured in the presence of glucose, fatty acids (palmitic acid and oleic acid), or a combination of both for $48 \mathrm{~h}$. When neonatal cardiomyocytes were exposed to fatty acids, either in the absence or presence of glucose, UCP-2 expression increased $>8$ fold as compared to cells receiving glucose as the sole substrate (Fig. 5.3). In H9c2

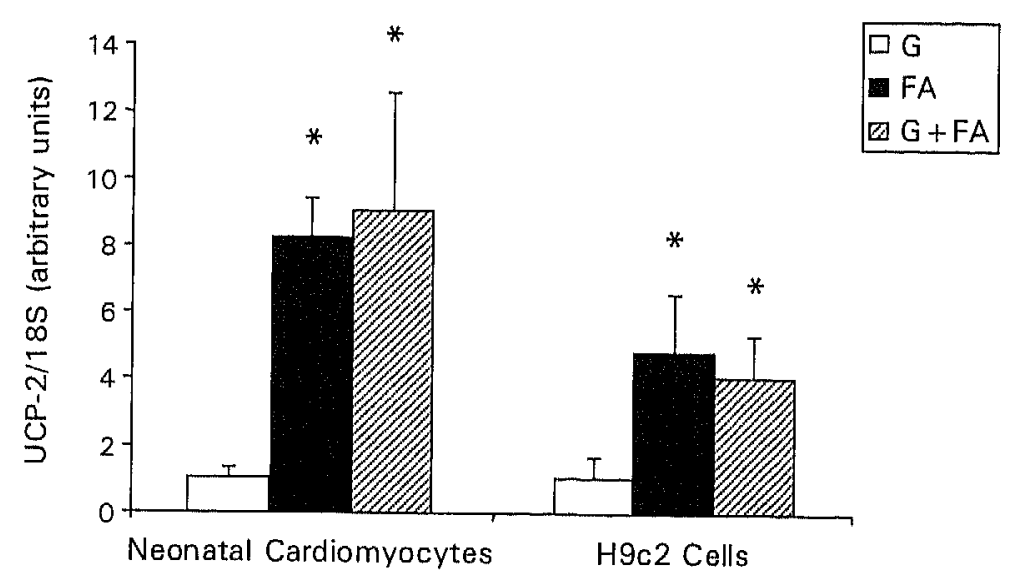

Figure 5.3 UCP-2 mRNA levels of neonatal rat cardiomyocytes and $H 9 \mathrm{c} 2$ cells cultured with glucose $(G)$, fatty acids (FA), or glucose plus fatty acids $(G+F A)$ as substrates for 48 h. mRNA levels were normalised to the corresponding $18 \mathrm{~S}$ ribosomal RNA signal to correct for possible loading differences. Data presented as means \pm SD of five or six experiments. * indicates significantly different from glucose only $(p<0.01)$. 
82 Chapter 5

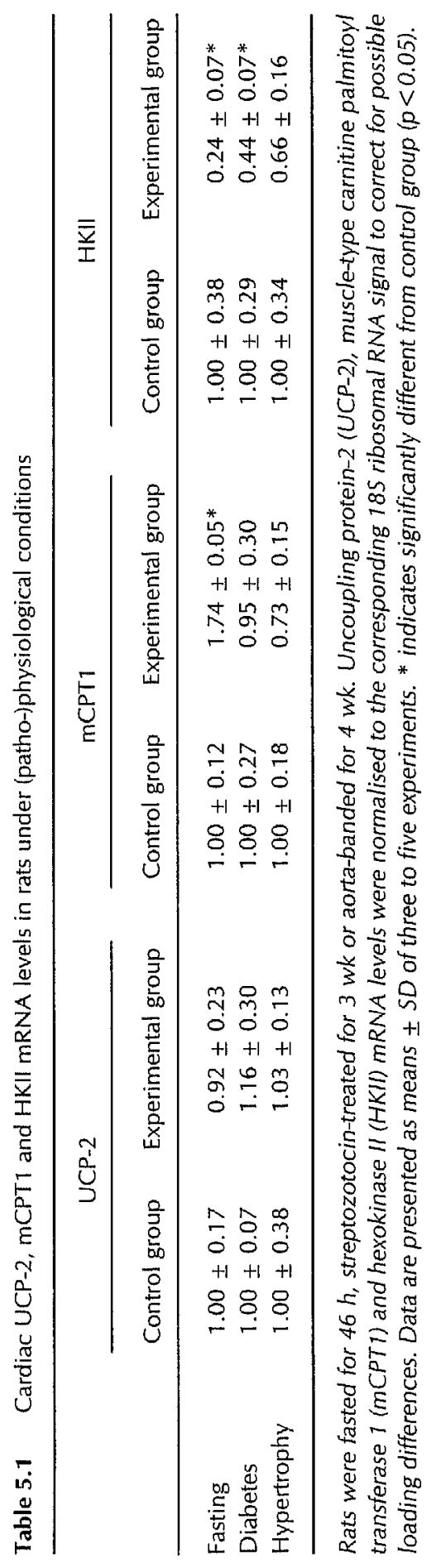


cells UCP-2 mRNA levels were also increased ( $>5$ fold) in the presence of fatty acids. As in vivo data suggested a relationship between serum insulin levels and UCP2 expression in white adipose tissue [37] and insulin was routinely added to the culture medium, it was also checked whether insulin affected fatty acid-induced UCP-2 expression in neonatal cardiomyocytes. In the absence as well as in the presence of different levels of insulin $(0.025$ and $0.25 \mathrm{mU} / \mathrm{ml})$, fatty acids gave rise to a comparable increase (7-10 fold) of the UCP-2 mRNA content (data not shown).

\section{Effects of phenylephrine and triiodothyronine on UCP-2 expression in vitro}

To investigate whether an in vitro effect on UCP-2 expression could be found under hypertrophic conditions, neonatal cardiomyocytes were stimulated with the $\alpha_{1-}$ adrenergic agonist phenylephrine (PE) in the presence or absence of fatty acids for 48 h. Administration of PE $(10 \mu \mathrm{M})$ resulted in a $1.45 \pm 0.06$ fold rise in cellular protein content. Mean cell area of ventricular myocytes increased from $91.3 \pm 15.0 \mu \mathrm{m}^{2}$ to $129.6 \pm 15.1 \mu^{2}$. UCP-2 mRNA levels, however, were not affected by PE stimulation, irrespective of the substrate composition of the culture medium (Fig. 5.4). In contrast, stimulation of the cells with the thyroid hormone T3 $(10 \mathrm{nM})$ resulted in a two-fold increased UCP-2 expression, though only in the presence of fatty acids.

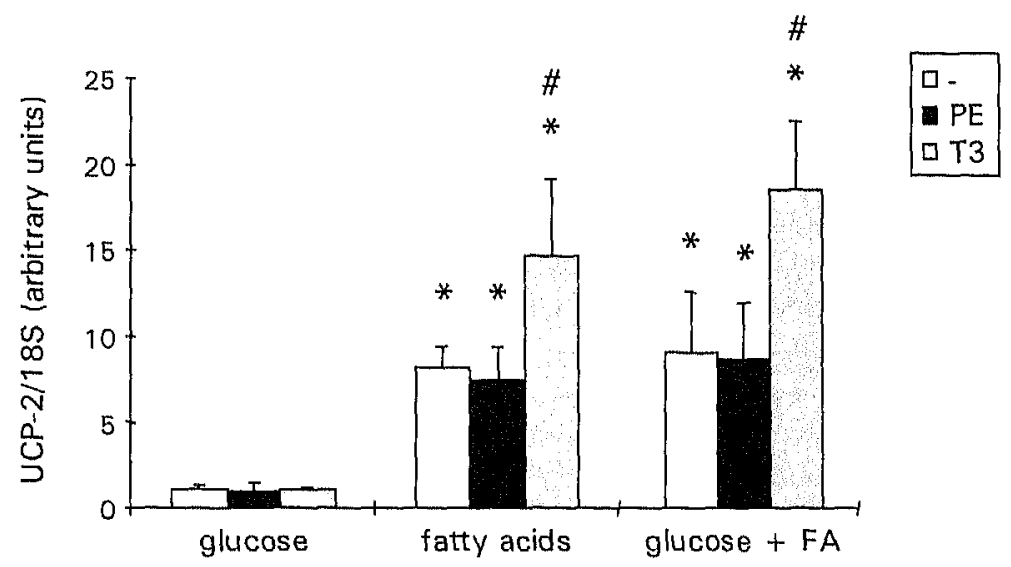

Figure 5.4 Effects of phenylephrine (PE) and triiodothyronine (T3) on UCP-2 mRNA levels of neonatal rat cardiomyocytes cultured with glucose, fatty acids, or glucose plus fatty acids as substrates for $48 \mathrm{~h}$. mRNA levels were normalised to the corresponding $18 \mathrm{~S}$ ribosomal RNA signal to correct for possible loading differences. Data presented as means $上$ SD of five independent experiments. * indicates $p<0.01$ versus the corresponding group with glucose as the only substrate. \# indicates $p<0.005$ versus non-stimulated cells receiving the same substrates.

\section{Effects of PPAR ligands on UCP-2 expression in vitro}

Next it was examined whether PPAR could be involved in the fatty acid-induced upregulation of UCP-2 in neonatal cardiomyocytes. To this end, neonatal rat ventricular myocytes receiving glucose as the only substrate were exposed to either 
the PPAR $\alpha$ specific ligand $W y-14,643(100 \mu M)$ or the PPAR $\gamma$ specific ligand ciglitazone $(10 \mu \mathrm{M})$ for $48 \mathrm{~h}$. Figure 5.5 demonstrates that the presence of the PPAR $\alpha$ ligand, but not the PPAR $\gamma$ ligand, dramatically increases UCP-2 gene expression. Addition of $W_{y}-14,643$ and ciglitazone in various concentrations $(1.0-1000 \mu \mathrm{M}$ and $0.1-100 \mu \mathrm{M}$ respectively; not shown) demonstrated that $W_{y-14,643}$ induced UCP-2 gene expression already at a dose of $1.0 \mu \mathrm{M}$ and was maximally effective at $100 \mu \mathrm{M}$, whereas ciglitazone did not affect UCP-2 expression, even at the highest dose applied.

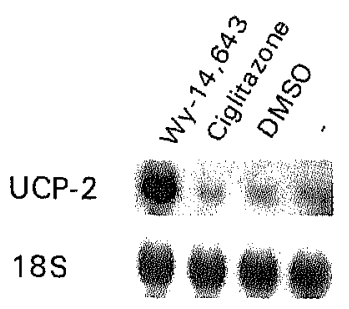

Figure 5.5 Effects of $W y-14,643$ and ciglitazone on UCP-2 mRNA levels of neonatal rat cardiomyocytes. Hybridisation signals of a representative northern blot are shown $(n=3)$. The 185 ribosomal RNA signal demonstrates possible loading differences.

\section{Discussion}

The present data demonstrate that the mRNA levels of UCP-2, abundantly present in the adult cardiac muscle, remain unchanged during fasting, diabetes and hypertrophy, i.e. (patho-)physiological conditions that are associated with changes in cardiac fatty acid utilisation. However, cardiac UCP-2 gene expression is rapidly upregulated during normal postnatal development. Moreover, in cultured neonatal rat cardiomyocytes and embryonic heart-derived $\mathrm{H} 9 \mathrm{c} 2$ cells fatty acids are found to induce UCP-2 expression, most likely through mechanisms involving transcription factors of the PPAR family.

\section{UCP-2 expression in adult rat heart}

During fasting and insulin-dependent diabetes, both plasma fatty acid levels and cardiac fatty acid oxidation increase in rats $[17,25,30]$. These conditions are associated with changes in the expression of various genes involved in cardiac metabolism, as reported previously for heart-type fatty acid-binding protein $[46,49]$ and as demonstrated for MCPT1 and HKII (see Table 5.1). In this respect, the absence of changes in cardiac UCP-2 mRNA levels is remarkable. In addition, cardiac hypertrophy, a condition which is associated with a decreased cardiac fatty acid oxidation [20] and concomitant downregulation of the expression of genes involved in fatty acid metabolism [34], does not affect UCP-2 expression either. The current findings are in line with recent observations by Hidaka and colleagues [19], who 
demonstrated that both fasting and streptozotocin-induced diabetes result in enhanced UCP-3, but not UCP-2 mRNA levels, in the rat heart.

From the literature the picture emerges that the regulation of UCP-2 expression in response to various stimuli is highly tissue-dependent. Previously Samec et al. [35] reported that $46 \mathrm{~h}$ of fasting, which was associated with a 3-fold rise in serum fatty acid levels, led to increases in UCP-2 and UCP-3 expression in gastrocnemius, soleus, and tibialis anterior skeletal muscles. Likewise, liver UCP-2 mRNA levels are highly responsive to changes in diet [42]. Apparently, conditions that are associated with changes in plasma fatty acid levels and/or fatty acid utilisation by the adult heart have no modulatory effect on adult cardiac UCP-2 expression. At present no satisfactory explanation can be provided for the behaviour of UCP in different tissues. As for the heart, in which the expression of UCP-2 is very pronounced, it has been suggested [19] that the promoter of the UCP-2 gene is so active under basal conditions that an increase in its activity can hardly be detected. However, this notion is hard to reconcile with the observation that in vivo administration of $\mathrm{T} 3$ as well as cold exposure increase cardiac UCP- 2 expression in the rat $[3,24]$. Furthermore, it does not explain why downregulation of UCP-2 expression is never observed, as for instance under conditions that are associated with a reduction in cardiac fatty acid utilisation, like cardiac hypertrophy.

\section{UCP-2 expression increases in the perinatal period}

Perinatally, a substantial rise in cardiac UCP-2 mRNA content was observed. In brown adipose tissue of mice a marked increase of UCP-2 mRNA levels at birth has also been demonstrated [8]. However, in contrast to the UCP-2 expression pattern in the heart, UCP-2 mRNA levels in brown adipose tissue returned to foetal levels within two weeks after birth [8]. The authors suggested that the postnatal rise in UCP-2 expression might be caused by cold exposure of the newborn animal when delivered to the extrauterine environment. The postnatal rise in circulating thyroid hormone levels [18] might also be responsible for the increase in UCP-2 expression after birth, since UCP2 expression has been shown to be T3-responsive in isolated neonatal cardiomyocytes (see below; [41]) and in the adult heart [24]. However, it should be kept in mind that nutritional factors also change during the perinatal period. Whereas the foetal diet consists mainly of carbohydrates, fat is the main component of the diet of suckling newborn animals (reviewed in [18]). During this period the heart also switches from carbohydrates to fatty acids as the main energy source [26]. Accordingly, it is tempting to speculate that the exposure to increased plasma fatty acid levels may directly be responsible for the increased UCP-2 mRNA levels. The current observation that fatty acids are able to enhance UCP-2 expression in neonatal cardiomyocytes seems to support this notion. On the other hand, manipulation of the diet directly after birth did not affect UCP-2 expression in skeletal muscle of mice [6]. In view of the tissue specific behaviour of uncoupling proteins, however, it remains to be established whether this also applies to UCP-2 gene expression in rat cardiac tissue. 
Fatty acids enhance UCP-2 expression in vitro

In primary cultures of neonatal rat ventricular myocytes and in embryonic heartderived $\mathrm{H} 9 \mathrm{C} 2$ cells fatty acids were able to stimulate UCP-2 gene expression to a significant extent (up to 10-fold). To our knowledge such a direct effect of fatty acids on cardiac UCP-2 expression has never been demonstrated before. The fact that fatty acids are able to enhance the expression of the UCP-2 gene as well as genes like heart-type fatty acid-binding protein, acyl-CoA synthetase, mCPT1, or long-chain acylCoA dehydrogenase in neonatal cardiomyocytes $[5,44,45]$, suggests a common mechanism. The exact mechanism by which fatty acids modulate UCP-2 expression is, however, unknown. Since fatty acids are able to activate PPARs [15,22], these transcription factors may be involved in the fatty acid-induced gene expression. Indeed, cardiac expression of the fatty acid-responsive mCPT1 gene has been demonstrated to be regulated by PPAR $\alpha[5,29]$. When $W y-14,643$, a specific activator of PPAR $\alpha$, was added to neonatal cardiomyocytes expression of UCP-2, as well as that of various genes involved in cardiac fatty acid transport and metabolism [45], increased dramatically. In contrast, the PPAR $\gamma$ specific ligand ciglitazone, a thiazolidinedione (TZD), did not affect UCP-2 expression. The fact that TZDs are able to enhance UCP-2 expression in a variety of other cell types, including adipocytes and the rat skeletal muscle cell line $L 6[1,7]$, most likely reflects differences in the tissue distribution of the corresponding PPARs, with PPAR $\gamma$ being abundantly present in adipocytes and virtually absent from cardiomyocytes. The involvement of PPAR in mediating fatty acid responsiveness to the UCP-2 gene is further supported by the observation that 9-cis retinoic acid, the ligand for the retinoid-X-receptor, which in turn acts as the dimerisation partner for PPAR, also enhances UCP-2 expression in cultured brown adipocytes [9]. However, it should be noted that, unlike UCP-1 [38], a functional PPAR response element, to the best of our knowledge, has not yet been identified in the UCP-2 gene.

Induction of neonatal myocyte hypertrophy with the $\alpha_{1}$-adrenergic agonist phenylephrine, which is an established model of in vitro hypertrophy [11], did not result in changes in UCP-2 gene expression. This observation corroborates the absence of alterations in UCP-2 mRNA levels in hypertrophied hearts of aorta-banded rats. In contrast, UCP-2 expression increased after enhancing cellular metabolism by the thyroid hormone T3. The current findings are in line with those of Teshima et al. [41], who reported a stimulatory effect of T3 and $\beta$-adrenergic agonists, but not of $\alpha_{1-}$ adrenergic agonists on UCP-2 expression in neonatal cardiomyocytes. It should be noted, however, that fatty acids are far more potent inducers of UCP-2 expression than either $\beta$-adrenergic agonists or T3. Furthermore, in our hands the stimulatory effect of T3 depended on the co-administration of fatty acids, which strongly suggests a permissive action of fatty acids to T3-induced UCP-2 expression.

\section{Physiological implications}

Taken together, the present findings indicate that the expression of UCP-2 in neonatal hearts, isolated neonatal cardiomyocytes and embryonic heart-derived $\mathrm{H} 9 \mathrm{c} 2$ cells is responsive to changes in the dietary environment, in contrast to its expression in the 
adult heart. Currently, the mechanism responsible for this difference in behaviour is unclear. First, it is striking that PPAR $\alpha$ ligands affect UCP-2 expression in neonatal cardiomyocytes but not in the adult rat heart after in vivo administration [21]. This coincides with the effects of PPAR $\alpha$ ligands on the expression of proteins involved in fatty acid transport and metabolism. Their expression is increased in neonatal cardiomyocytes after addition of the PPAR $\alpha$ specific ligand $W y-14,643$ [45], while mRNA levels of fatty acid transport protein and acyl-COA synthetase are hardly altered after administration of a potent PPAR $\alpha$ activator to adult rats [28]. Second, it should be noted that the changes in fatty acid levels in the cellular model systems $(0.0 \mathrm{mM}$ versus $0.5 \mathrm{mM})$ and during the perinatal development $(0.02$ to $0.4 \mathrm{mM})$ [27] are more outspoken than those induced by fasting and diabetes $(0.3$ to $1.5 \mathrm{mM})$. It is conceivable that maximal stimulation of cardiac UCP-2 expression by fatty acids is already achieved at the relatively high circulating fatty acid levels found in adult rats.

Although UCP-2 is abundantly expressed in the heart, the biological significance of UCP-2 in this tissue is incompletely understood. It has been hypothesised that mitochondrial uncoupling reduces the formation of reactive oxygen species, byproducts of mitochondrial oxidation [32,39]. In this respect, uncoupling by both ADP/ATP translocase and UCP-2 has been demonstrated to mediate this antioxidant effect, as evidenced by their capacity to inhibit mitochondrial formation of $\mathrm{H}_{2} \mathrm{O}_{2}$ $[23,32]$. Although the uncoupling activity of UCP-1 can be enhanced by fatty acids [16], a direct stimulatory effect of fatty acids on UCP-2 uncoupling activity has not been demonstrated so far. The fact that in neonatal cardiomyocytes fatty acids induce UCP-2 along with a panel of genes encoding proteins known to be involved in cardiac fatty acid transport and metabolism [45], is indicative of a relationship between UCP-2 and fatty acid handling. The finding that the modulatory effects of fatty acids on UCP-2 gene expression appears to be restricted to neonatal cardiomyocytes and absent in the adult heart is very intriguing and warrants further investigation.

\section{Acknowledgements}

The research was funded by grants 97.092 and D98.015 of the Netherlands Heart Foundation.

\section{References}

1. Aubert J, Champigny O, Saint-Marc P, Negrel R, Collins S, Ricquier D, and Ailhaud G (1997). Up-regulation of UCP-2 gene expression by PPAR agonists in preadipose and adipose cells. Biochem Biophys Res Commun 238, 606-611

2. Bachmann $E$ and Weber $E$ (1990). Effects of corn oil addition to the diet on the energy metabolism of heart, liver and kidney of female rats. Pharmacol Toxicol 67, 49-55

3. Boss O, Samec S, Dulloo A, Seydoux J, Muzzin P, and Giacobino J-P (1997). Tissuedependent upregulation of rat uncoupling protein-2 expression in response to fasting or cold. FEBS Lett 412, 111-114 
4. Boss O, Samec S, Paoloni-Giacobino A, Rossier C, Dulloo A, Seydoux I, Muzzin P, and Giacobino J.P (1997). Uncoupling protein-3: a new member of the mitochondrial carrier tamily with tissue-specific expression. FEBS Lett 408, 39-42

5. Brandt JM, Djouadi F, and Kelly DP (1998). Fatty acids activate transcription of the muscle carnitine palmitoyltransierase I gene in cardiac myocytes via the peroxisome proliferatoractivated receptor a. I Biol Chem 273, 23786-23792

6. Brun 5, Carmona $M C$, Mampel T, Viñas $O$, Giralt $M$, Iglesias $R$, and Villarroya $F(1999$ ). Activators of peroxisome proliferator-activated receptor-a induce the expression of the uncoupling protein-3 gene in skeletal muscle. A potential mechanism for the lipid intakedependent activation of uncoupling protein-3 gene expression at birth. Diabetes 48,1217 1222

7. Camirand A, Marie V, Rabelo R, and Silva JE (1998). Thiazoldinediones stimulate uncoupling protein-2 expression in cell lines representing white and brown adipose tissues and skeletal muscle. Endocrinology 139, 428-431

8. Carmona MC, Valmaseda A, Brun S, Viñas O, Mampel T, Iglesias R, Giralt M, and Villarroya F (1998). Differential regulation of uncoupling protein-2 and uncoupling protein-3 gene expression in brown adipose tissue during development and cold exposure. Biochem Biophys Res Commun 243, 224-228

9. Carmona MC, Valmaseda A, Iglesias $R$, Mampel $T$, Viñas $O$, Giralt $M$, and Villarroya $F(1998$ ). 9-cis Retinoic acid induces the expression of the uncoupling protein-2 gene in brown adipocytes. FEBS Lett $441,447-450$

10. Challoner DR and Steinberg D (1966). Effect of free fatty acid on the oxygen consumption of perfused rat heart. Am / Physiol 210, 280-286

11. Chien KR, Knowlton KU, Zhu H, and Chien S (1991). Regulation of cardiac gene expression during myocardial growth and hypertrophy: molecular studies of an adaptive physiologic response. FASEB / 5, 3037-3046

12. De Vries JE, Vork MM, Roemen THM, de Jong YF, Cleutjens JPM, van der Vusse GJ, and van Bilsen $M$ (1997). Saturated but not mono-unsaturated fatty acids induce apoptotic cell death in neonatal rat ventricular myocytes. / Lipid Res 38, 1384-1394

13. Engels W, van Bilsen $M$, Wolffenbuttel $B H R$, van der Vusse $G$, and Glatz JFC (1999). Cytochrome $\mathrm{P} 450$, peroxisome proliferation, and cytoplasmic fatty acid-binding protein content in liver, heart and kidney of the diabetic rat. Mol Cell Biochem 192, 53-61

14. Fleury $C$, Neverova M, Collins S, Raimbault S, Champigny O, Levi-Meyrueis C, Bouillaud F, Seldin MF, Surwit RS, Ricquier D, and Warden $\mathrm{CH}$ (1997). Uncoupling protein-2: a novel gene linked to obesity and hyperinsulinemia. Nature Genet 15, 269-272

15. Forman BM, Chen I, and Evans RM (1997). Hypolipidemic drugs, polyunsaturated fatty acids, and eicosanoids are ligands for peroxisome proliferator-activated receptors $\alpha$ and $\delta$. Proc Natl Acad Sci USA 94, 4312-4317

16. Garlid KD, Orosz DE, Modriansky M, Vassanelli S, and jezek P (1996). On the mechanism of fatty acid-induced proton transport by mitochondrial uncoupling protein. J Biol Chem 271, 2615-2620

17. Ghezzi $C$, Dubois $F$, Mathieu JP, Cand F, Comet $M$, and Cuchet $P(1990)$. Effect of short-term fasting on [123l] iodohexadecenoic acid metabolism in the isolated perfused rat heart. Validation of mathematical model by comparison with experimental measurements. Arch Int Physiol Biochim 98, 269-281

18. Girard J, Ferré P, Pégorier J-P, and Duée P-H (1992). Adaptations of glucose and fatty acid metabolism during perinatal period and suckling-weaning transition. Physiol Rev 72, 507-562

19. Hidaka S, Kakuma T, Yoshimatsu H, Sakino H, Fukuchi S, and Sakata T (1999). Streptozotocin treatment upregulates uncoupling protein 3 expression in the rat heart. Diabetes 48, 430-435

20. Kagaya Y, Kanno Y, Takeyama D, Ishide N, Maruyama Y, Takahashi T, Ido T, and Takishima T (1990). Effects of long-term pressure overload on regional myocardial glucose and free fatty acid uptake in rats. A quantitative autoradiographic study. Circulation 81, 1353-1361 
21. Kelly Lf, Vicario PP, Thompson GM, Candelore MR, Doebber TW, Ventre J, Wu MS, Meurer R, Forrest MJ, Conner MW, Cascieri MA, and Moller DE (1998). Peroxisome proliferatoractivated receptors $g$ and a mediate in vivo regulation of uncoupling protein (UCP-1, UCP-2, UCP-3) gene expression. Endocrinology 139, 4920-4927

22. Kliewer SA, Sundseth SS, Jones SA, Brown PJ, Wisely GB, Koble CS, Devchand P, Wahli W, Willson TM, Lenhard JM, and Lehmann JM (1997). Fatty acids and eicosanoids regulate gene expression through direct interactions with peroxisome proliferator-activated receptors $\alpha$ and \%. Proc Natl Acad Sci USA 94, 4318-4323

23. Korshunov SS, Korkina OV, Ruuge EK, Skulachev VP, and Starkov AA (1998). Fatty acids as natural uncouplers preventing generation of $\mathrm{O}_{2}^{-}$and $\mathrm{H}_{2} \mathrm{O}_{2}$ by mitochondria in the resting state. FEBS Lett 435, 215-218

24. Lanni A, De Felice $M$, Lombardi A, Moreno $M$, Fleury C, Ricquier D, and Goglia $F$ (1997). Induction of UCP: mRNA by thyroid hormones in rat heart. FEBS Lett 418, 171-174

25. Lopaschuk GD (1992). Fatty acid metabolism in the heart following diabetes, In the heart in diabetes. Chatham JC, Forder JR, and MCNeill JH, Eds. Kluwer Academic Publishers, Boston, 215-251

26. Lopaschuk GD, Collins-Nakai RL, and Itoi $T$ (1992). Developmental changes in energy substrate use by the heart. Cardiovasc Res 26, 1172-1180

27. Makinde A-O, Kantor PF, and Lopaschuk GD (1998). Maturation of fatty acid and carbohydrate metabolism in the newborn heart. Mol Cell Biochem 188, 49-56

28. Martin G, Schoonjans K, Lefebvre A-M, Staels B, and Auwerx J (1997). Coordinate regulation of the expression of the fatty acid transport protein and acyl-CoA synthetase genes by PPAR $\alpha$ and PPAR $\gamma$ activators. / Biol Chem 272, 28210-28217

29. Mascaró C, Acosta E, Ortiz JA, Marrero PF, Hegardt FG, and Haro D (1998). Control of human muscle-type carnitine palmitoyltransferase I gene transcription by peroxisome proliferatoractivated receptor. / Biol Chem 273, 8560-8563

30. Menahan LA and Sobocinski KA (1983). Comparison of carbohydrate and lipid metabolism in mice and rats during fasting. Comp Biochem Physiol 74B, 859-864

31. Millet $L$, Vidal $H$, Andreelli $F$, Larrouy $D$, Riou $J-P$, Ricquier $D$, Laville $M$, and Langin $D$ (1997). Inreased uncoupling protein-2 and -3 mRNA expression during fasting in obese and lean humans. J Clin invest 100, 2665-2670

32. Nègre-Salvayre $A$, Hirtz $C$, Carrera $G$, Cazenave $R$, Troly $M$, Salvayre $R$, Pénicaud $L$, and Casteilla $L$ (1997). A role for uncoupling protein-2 as a regulator of mitochondrial hydrogen peroxide generation. FASEB / 11, 809-815

33. Ricquier $D$ and Bouillaud $F$ (1997). The mitochondrial uncoupling protein: Stuctural and genetic studies. Prog Nucleic Acid Res Mol Biol 56, 83-108

34. Sack MN, Rader TA, Park S, Bastin J, McCune SA, and Kelly DP (1996). Fatty acid oxidation enzyme gene expression is downregulated in the failing heart. Circulation 94, 2837-2842

35. Samec S, Seydoux J, and Dulloo AC (1998). Interorgan signaling between adipose tissue metabolism and skeletal muscle uncoupling protein homologs. Is there a role for circulating free fatty acids? Diabetes 47, 1693-1698

36. Samec S, Seydoux \}, and Dulloo AG (1998). Role of UCP homologues in skeletal muscles and brown adipose tissue: mediators of thermogenesis or regulators of lipids as fuel substrate? FASEB / 12, 715-724

37. Savontaus E, Rouru ], Boss O, Huupponen R, and Koulu M (1998). Differential regulation of uncoupling proteins by chronic treatments with beta 3-adrenergic agonist BRL 35135 and metformin in obese fa/fa Zucker rats. Biochem Biophys Res Commun 246, 899-904

38. Sears IB, MacGinnitie MA, Kovacs LG, and Graves RA (1996). Differentiation-dependent expression of the brown adipocyte uncoupling protein gene: Regulation by peroxisome proliferator-activated receptor $\gamma$. Mol Cell Biol 16, 3410-3419

39. Skulachev VP (1998). Uncoupling: new approaches to an old problem of bioenergetics. Biochim Biophys Acta 1363, 100-124 
40. Snoeckx LHEH, van der Vusse GJ, Coumans WA, and Reneman RS (1990). The effects of global ischemia and reperfusion on compensated hypertrophied hearts of aorta-banded rats. $J$ Mol Cell Cardiol 22, 1439-1451

41. Teshima Y, Saikawa T, Yonemochi H, Hidaka S, Yoshimatsu $H$, and Sakata $T$ (1999). Alteration of heart uncoupling protein-2 mRNA regulated by sympathetic nerve and triiodothyronine during postnatal period in rats. Biochim Biophys Acta 1448, 409-415

42. Tsuboyama-Kasaoka N, Takahashi $M$, Kim H, and Ezaki $O$ (1999). Up-regulation of liver uncoupling protein-2 mRNA by either fish oil feeding or fibrate administration in mice. Biochem Biophys Res Commun 257, 879-885

43. Van Bilsen M, de Vries JE, and van der Vusse GJ (1997). Long-term effects of fatty acids on cell viability and gene expression of neonatal cardiac myocytes. Prostaglandins Leukot Essent Fatty Acids 57, 30-45

44. Van Bilsen M, van der Lee KAJM, and van der Vusse GJ (1999). Long-chain fatty acids and signal transduction in the cardiac muscle cell. In Cardiovascular specific gene expression. Doevendans PA, Reneman RS, and van Bilsen M, Eds. Kluwer Academic Publishers, Dordrecht, the Netherlands, 257-268

45. Van der Lee KAJM, Vork MM, de Vries JE, Willemsen PHM, Glatz JFC, Reneman RS, van der Vusse GJ, and van Bilsen $M(2000)$. Long-chain fatty acid-induced changes in gene expression in neonatal cardiac myocytes. / Lipid Res 41, 41-47

46. Van Nieuwenhoven FA, Willemsen PHM, van der Vusse GJ, and Glatz JFC (1999). Coexpression in rat heart and skeletal muscle of four genes coding for proteins implicated in long-chain fatty acid uptake. Int / Biochem Cell Biol 31, 489-498

47. Vidal-Puig A, Solanes G, Grujic D, Flier JS, and Lowell BB (1997). UCP3: An uncoupling protein homologue expressed preferentially and abundantly in skeletal muscle and brown adipose tissue. Biochem Biophys Res Commun 235, 79-82

48. Wallenstein S, Zucker CL, and Fleiss JL (1980). Some statistical methods useful in circulation research. Circ Res 47, 1-9

49. Willemsen PHM, van der Lee KAJM, van der Vusse GJ, Samec S, and van Bilsen M (1999). Fasting affects metabolic gene expression in the rat heart. Abstract. / Mol Cell Cardiol 31, A89

50. Winkler $E$ and Klingenberg $M$ (1994). Effect of fatty acids on $\mathrm{H}^{+}$transport activity of the reconstituted uncoupling protein. / Biol Chem 269, 2508-2515 


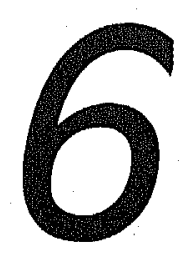

\section{Fasting-induced changes in the expression of genes controlling substrate metabolism in the rat heart}

Karin AJM van der Lee, Peter HM Willemsen, Sonia Samec*, Josiane Seydoux**, Abdul G Dulloo*, Maurice MAL Pelsers, Jan FC Glatz, Ger J van der Vusse, and Marc van Bilsen

Department of Physiology, Cardiovascular Research Institute Maastricht, Maastricht University, the Netherlands

* Institute of Physiology, University of Fribourg, Switzerland

** Department of Physiology, Faculty of Medicine, University of Geneva, Switzerland 


\begin{abstract}
During fasting, when overall metabolism changes, the contribution of glucose and fatty acids (FA) to cardiac energy production alters as well. Here, we examined if the heart is able to adapt to such fasting-induced changes by modulation of its gene expression. Rats were fed ad libitum or fasted for $46 \mathrm{~h}$, resulting in reduced circulating glucose levels and a three-fold rise in FA. Besides changes in the cardiac activity or content of proteins involved in g/ucose or FA metabolism, mRNA levels also altered. The expression of genes coding for glucose-handling proteins (glucose transporter GLUT4, hexokinase $($ and II) declined up to $70 \%$ as a result of fasting. In contrast, the mRNA levels of various genes involved in $F A$ transport and metabolism (FA translocase/CD36, muscle-type carnitine palmitoyl transferase 1, long-chain acylCOA dehydrogenase) and of the uncoupling protein UCP-3 increased over $50 \%$ in hearts of fasted rats. Surprisingly, $m R N A$ levels of the fatty acid-activated transcription factors PPAR $\alpha$ and PPAR $\beta / \delta$ were reduced in hearts of fasted rats. Reducing FA levels by nicotinic acid administration during the final $8 \mathrm{~h}$ of fasting did not affect the expression of the majority of metabolic genes, but totally abolished the induction of $U C P-3$. In conclusion, the adult rat heart responds to changes in nutritional status, as provoked by $46 \mathrm{~h}$ fasting, through adjustment of glucose and FA metabolism at the level of gene expression.
\end{abstract}

\title{
Introduction
}

Under physiological conditions glucose and fatty acids are the main substrates for energy conversion in the heart $[29,36]$. During conditions in which whole-body metabolism changes, the relative contribution of individual substrates to cardiac energy production will alter. For example, during fasting or diabetes the contribution of fatty acids to cardiac energy production increases whereas the utilisation of glucose is reduced $[17,19]$. Under both conditions circulating fatty acid concentrations are increased [5,21], implicating an enhanced supply of these substrates to the myocardium.

Recently we have demonstrated that long-term exposure of primary cultures of rat neonatal cardiac myocytes to fatty acids resulted in an increased fatty acid oxidation capacity [34]. This was accompanied by a specific and co-ordinated upregulation of the expression of genes involved in cellular fatty acid transport and metabolism, whereas the expression of the insulin-sensitive glucose transporter GLUT4 declined $[31,34]$. These data point to metabolic plasticity of cardiac muscle cells, i.e. the ability to respond to changes in substrate supply by adjusting the expression of genes encoding proteins involved in substrate transport and metabolism.

In the present study we have examined whether metabolic plasticity is an inherent feature of the cardiac muscle in vivo. Because circulating substrate levels and, hence, 
substrate supply to the heart are altered during prolonged fasting, the effect of food deprivation was studied in rats which were refrained from food for $46 \mathrm{~h}$. The ability of the heart to adapt to metabolic changes was monitored by analysing the contents or enzymatic activities of a number of proteins concerned in cardiac transport and metabolism of either fatty acids or glucose. Moreover, the mRNA levels of a variety of metabolic genes were determined to explore the possibility that the plasticity, if present, was related to alterations in gene expression. The expression of the uncoupling proteins UCP-3 and UCP-2, which have been proposed to uncouple mitochondrial oxidative phosphorylation $[8,10]$, was determined, as we recently observed that the expression of these proteins seems to be responsive to fatty acids too, at least in cardiac and slow oxidative muscle $[22,35]$. In addition, the expression of the fatty acid-activated transcription factors PPAR $\alpha$ and PPAR $\beta / \delta$ (also referred to as FAAR or $\mathrm{NUCl}$ ) was examined, since these factors are thought to play a regulatory role in the expression of genes involved in lipid handling [7]. Finally, it was investigated whether reduction of plasma fatty acids by nicotinic acid treatment during the last $8 \mathrm{~h}$ of the fasting period could reverse the potential changes in mRNA and protein levels in the fasted heart.

\section{Materials and methods}

\section{Animals}

In this study 6 weeks old male Sprague-Dawley rats (Tierzucht, Zürich, Switzerland) were used, as described in detail by Samec et al. [22]. Animals were maintained on a commercially available diet (Provimi-Lacta, Cossonay, Switzerland) consisting (by energy) of $24 \%$ protein, $66 \%$ carbohydrates, and $10 \%$ fat, and had free access to water. Rats were either fed ad libitum or fasted for $46 \mathrm{~h}$. During fasting all animals had free access to water containing $0.45 \% \mathrm{NaCl}$. In a subgroup of rats the antilipolytic agent nicotinic acid (Fluka Biochimica, Buchs, Switzerland) was administered at 100 $\mathrm{mg} / \mathrm{kg}$ i.p. every $2 \mathrm{~h}$ during the last $8 \mathrm{~h}$ of the fasting period according to Lowell [15]. Sterile saline was administered to the control animals. This resulted in four experimental groups (fed/-, fasted/-, fed/NA, and fasted/NA, $n=5$ per group). Rats were killed by decapitation $2 \mathrm{~h}$ after the last i.p. injection. Blood was collected to assess serum fatty acids and glucose. Hearts were excised, immediately frozen in liquid nitrogen, and stored at $-80^{\circ} \mathrm{C}$. Frozen tissue was homogenised by grinding with a pre-cooled mortar and pestle. The powder was divided into two portions, one for RNA analysis and the other for preparation of $5 \%(\mathrm{w} / \mathrm{V})$ homogenates in SET buffer (0.25 M sucrose, $2 \mathrm{mM}$ EDTA, $10 \mathrm{mM}$ Tris, $\mathrm{pH}$ 7.4). The latter was used for analysis of enzyme activities and protein contents.

\section{Biochemical analyses}

Serum fatty acids were measured using a NEFA $C$ kit (Wako Chemicals, Neuss, Germany), and serum glucose concentrations were determined on a Beckman glucose analyser (Beckman Instruments, Palo Alto CA, USA). 
Hexokinase (HK; EC 2.7.1.1), 3-hydroxyacyl-CoA dehydrogenase (HAD; EC 1.1.1.35), and citrate synthase (CS; EC 4.1.3.7) activities in cardiac muscle homogenates were analysed on a Cobas Bio centrifugal analyser (Roche Diagnostics, Basel, Switzerland) using an UV-assay $[1,2,28]$. Enzyme activities are expressed per $\mathrm{mg}$ total protein as determined with the micro BCA method (Pierce, Rockford IL, USA), using BSA as standard. Absorbance was read at $450 \mathrm{~nm}$ using a Titertek Multiscan MKII microplate reader.

\section{Enzyme-linked immunosorbent assays (ELISAs)}

For the quantification of fatty acid translocase (FAT/CD36) an ELISA was used according to Pelsers et al. [20]. In brief, a microtiter plate was coated overnight at $4{ }^{\circ} \mathrm{C}$ with a monoclonal antibody against human platelet FAT, crossreacting with rat FAT. After washing with $200 \mu \mathrm{l}$ PBS containing $0.1 \%$ BSA (w/v) and $0.05 \%(\mathrm{v} / \mathrm{v})$ Tween-20 (PBT), wells were blocked with PBS/2\% Marvell dried milk powder (Chivers and Sons Ltd., Dublin, Ireland). After washing with PBT, $100 \mu$ l of homogenate (pre-treated with $2 \%$ Triton $\mathrm{X}-100$ for $1 \mathrm{~h}$ at $37^{\circ} \mathrm{C}$, centrifuged for $2 \mathrm{~min}$ at $13,000 \mathrm{rpm}$, and diluted in PBT) or standard ( 0 to $100 \mu \mathrm{g} / \mathrm{l}$ ) was added and incubated for $90 \mathrm{~min}$ at room temperature. Wells were washed and incubated with phage $M 13\left(2 \times 10^{11}\right.$ c.f.u. $/ \mathrm{ml}$ in PBS/2\% Marvell) for $1 \mathrm{~h}$ at room temperature. After washing, 1:5000-diluted monoclonal anti-M13 (peroxidase labelled) in PBS/2\% Marvell was added. Incubation for $1 \mathrm{~h}$ was followed by five washes and addition of $100 \mu \mathrm{l}$ substrate. After 5 minutes the reaction was stopped by adding $50 \mu$ stop solution. The absorbance was read at $450 \mathrm{~nm}$ using a microplate reader.

To determine the tissue content of heart-type fatty acid-binding protein (H-FABP), a sandwich-type ELISA for rodent H-FABP (according to Wodzig et al. [37]) was provided by Hycult Biotechnology, Uden, the Netherlands. In short, first $50 \mu \mathrm{l}$ of the second monoclonal antibody against H-FABP (conjugated with horseradish peroxidase) and $50 \mu \mathrm{l}$ of either diluted homogenates or standards of 0 to $25 \mu \mathrm{g} / \mathrm{H} \mathrm{H}$ FABP were added to the wells which were precoated with the first monoclonal antibody. After incubation at room temperature for $2 \mathrm{~h}$, the wells were washed four times with $200 \mu \mathrm{l}$ buffer followed by the addition of $100 \mu l$ substrate solution. After 15 min the reaction was stopped by adding $100 \mu \mathrm{l}$ stop solution. Absorbance was read at $450 \mathrm{~nm}$ using a microplate reader.

\section{Northern blotting analysis}

Total RNA was isolated with TRIzol reagent (Gibco BRL Life Technologies, Gaithersburg MD, USA). $10 \mu \mathrm{g}$ of total RNA was size-fractionated on a denaturing gel, transferred to a nylon membrane (Hybond-NX, Amersham, Slough, UK), and fixed with standard techniques. Following prehybridisation the filters were probed with fragments of cDNA of GLUT4, hexokinase $\|$ (HKII), FAT/CD36, H-FABP, acyl-CoA synthetase (ACS), long-chain acyl-CoA dehydrogenase (LCAD), or uncoupling protein2 (UCP-2) as described previously [34,35]. A $2.1 \mathrm{~kb}$ EcoRl fragment of rat glucose transporter GLUT1 cDNA (a gift of Dr. A. Zorzano, University of Barcelona, Spain), a $0.6 \mathrm{~kb}$ Bglll fragment of rat hexokinase I (HKI; a gift of Dr. J.E. Wilson, Michigan State University, USA), a $0.5 \mathrm{~kb} \mathrm{Kpnl}-\mathrm{BamHI}$ fragment of muscle-type carnitine palmitoyl 
transferase 1 (mCPT1; kindly provided by Dr. F. van de Leij, University of Groningen, the Netherlands), a Pstl fragment of mouse peroxisome proliferator-activated receptor $\alpha$ (PPAR $\alpha$; kindly provided by Dr. J. Auwerx, Institute Pasteur, Lille, France), and a 1.5 $\mathrm{kb} \mathrm{BamHI}$ fragment of rat PPAR $\beta / \delta$ (a gift of Dr. P.A. Grimaldi, University of Nice, France) were also used for hybridisation as well as a $1.0 \mathrm{~kb}$ fragment of rat CS generated via reverse transcriptase PCR using forward (5'-ATCCGTTTCCGACGCTWY AGT $\left.-3^{\prime}\right)$ and reversed (5'-CGTGAYACCCCRAACAGCACY-3') primers, and a $0.7 \mathrm{~kb}$ fragment of rat UCP-3 also generated via RT-PCR using (5'-CGCCATCCTCCGCAA CCATCG- $3^{\prime}$ ) and (5'-GCGGCCTGCTTCCCTTGTTCA- $3^{\prime}$ ) as forward and reversed primers, respectively. The cDNA probes were labelled with $\left[\alpha-{ }^{32} \mathrm{P}\right] \mathrm{dCTP}(3000 \mathrm{Ci} / \mathrm{-}$ mmol; Amersham) by random-priming (Radprime, Gibco BRL) to a specific activity of $>0.5 \times 10^{9} \mathrm{cpm} / \mu \mathrm{g}$ DNA. To correct for possible differences in loading and transfer filters were also hybridised with ${ }^{32} \mathrm{P}$-labelled ribosomal $18 \mathrm{~S}$ probe. Following hybridisation filters were washed at the appropriate stringency to remove non-specific binding. The filters were exposed for 18-36 hours to imaging screens, and subsequently scanned on the Personal FX Imager (Bio-Rad Laboratories, Hercules CA, USA). Signals were quantified using Quantity One software (Bio-Rad Laboratories).

\section{Statistical analysis}

Results are expressed as means \pm SD. Data were analysed using a two-way analysis of variance (ANOVA) for the main effects of group (fed versus fasted), treatment condition (saline versus nicotinic acid), and group $X$ treatment condition interaction. Differences were considered significant at $p<0.05$.

\section{Results}

\section{Effects of fasting}

To explore the plasticity of cardiac metabolism to adapt to changes in whole body metabolism fasting was used as a mean to modulate extracellular substrate availability. As shown in table 6.1, fasting had pronounced effects on serum substrate concentrations. After $46 \mathrm{~h}$ of fasting glucose concentrations were approximately $30 \%$ lower and fatty acid concentrations 3 -fold higher in fasted rats than in fed rats.

The fasting-induced decline in serum glucose and rise in fatty acid concentrations were associated with a small, though statistically significant, reduction in the cardiac activity of the glycolytic enzyme hexokinase (HK) and a rise in the activity of 3hydroxyacyl-CoA dehydrogenase (HAD), an enzyme involved in mitochondrial fatty acid $\beta$-oxidation (Fig. 6.1). The activity of the citric acid cycle enzyme citrate synthase (CS) did not significantly differ between hearts of fed and fasted rats, indicating that the mitochondrial population in the heart was unaltered by fasting.

ELISAs were performed to investigate whether the fasting-induced rise in fatty acid availability was also reflected by changes in the levels of fatty acid transport proteins. 


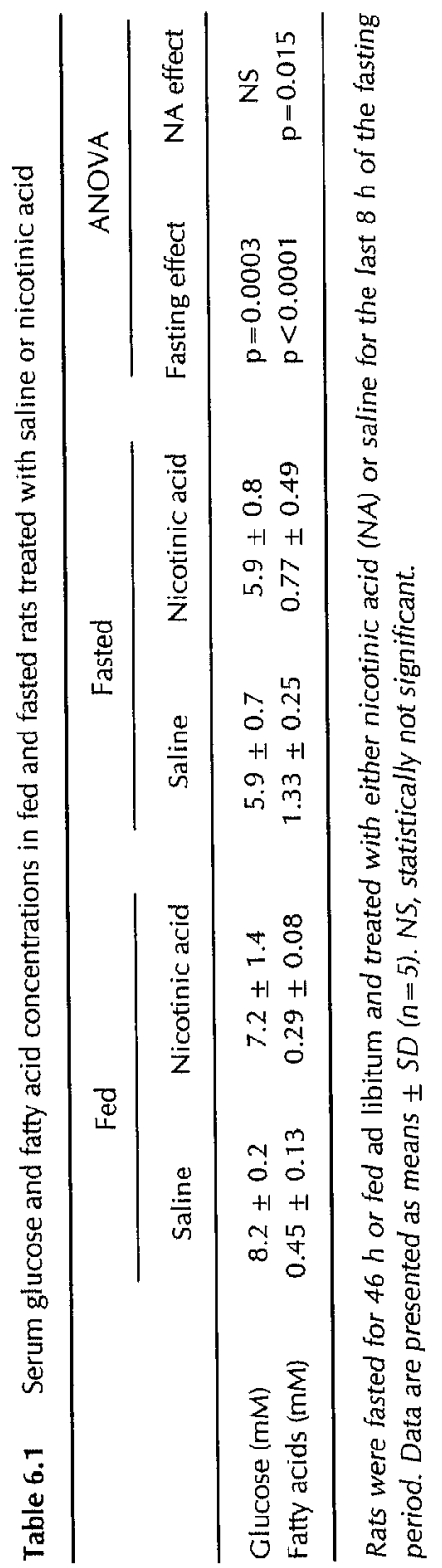


Figure 6.2 illustrates that the protein content of the cytosolic heart-type fatty acidbinding protein (H-FABP) did not change significantly as a result of fasting. However, the protein content of the transsarcolemmal fatty acid translocase FAT/CD36 had nearly doubled after $46 \mathrm{~h}$ of food deprivation.

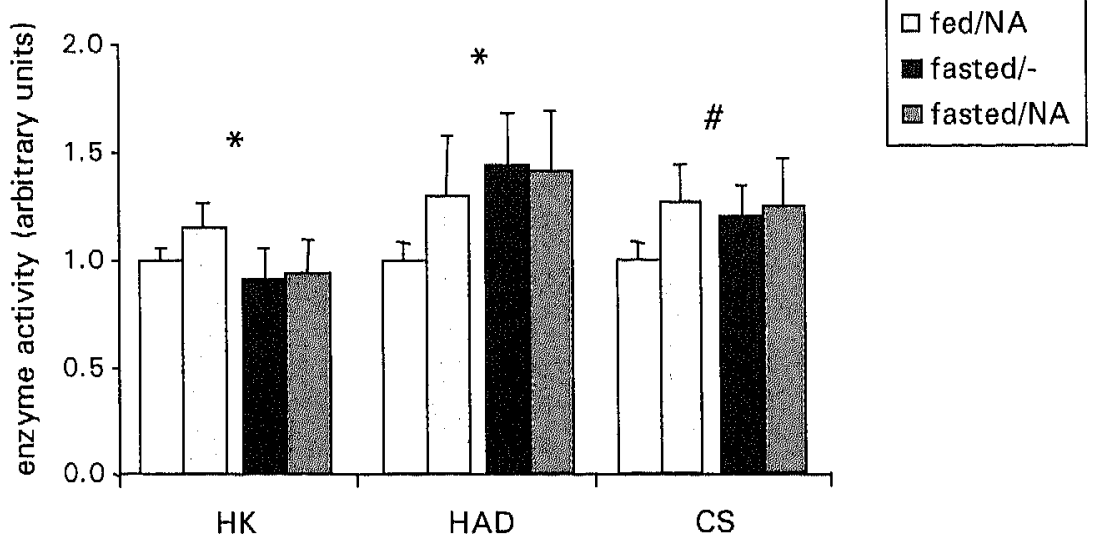

Figure 6.1 Effects of $46 \mathrm{~h}$ fasting and $8 \mathrm{~h}$ nicotinic acid treatment on enzyme activities in the rat heart. Activities of 3-hydroxyacyl-CoA dehydrogenase (HAD), hexokinase (HK), and citrate synthase (CS) amounted to $487 \pm 40,33 \pm 2$, and $743 \pm 56 \mathrm{U} / \mathrm{g}$ protein in fed/- hearts, respectively, and were normalised by setting the control group (fed/-) at 1,0. Data are presented as means $\pm S D(n=5)$; * indicates significant $(p<0.05)$ effect of fasting, and \# indicates significant $(p<0.05)$ effect of nicotinic acid by two-way ANOVA.

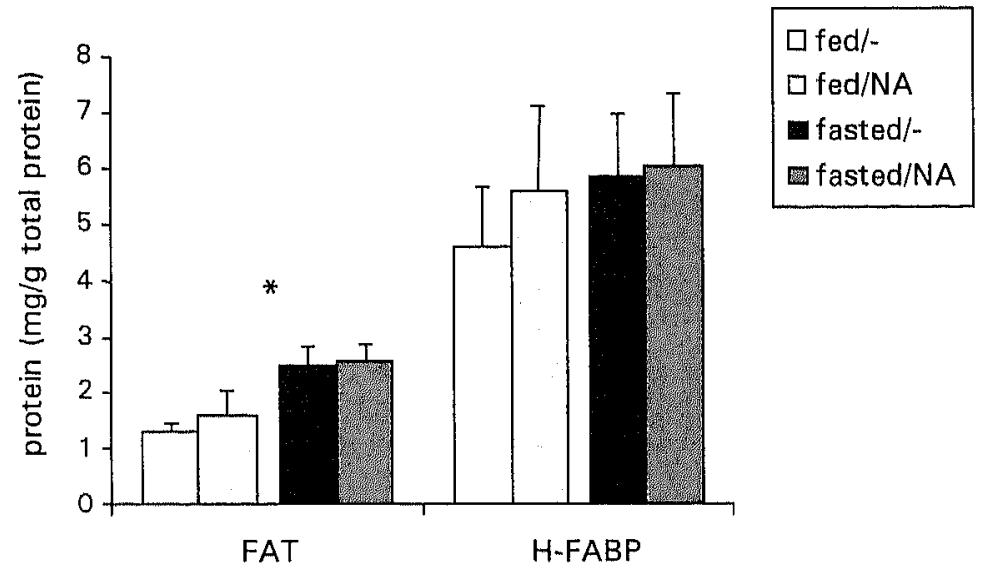

Figure 6.2 Effects of $46 \mathrm{~h}$ fasting and $8 \mathrm{~h}$ nicotinic acid treatment on contents of fatty acid translocase/CD36 (FAT) and heart-type fatty acid-binding protein (H-FABP) in the rat heart. Data are presented as means $\pm S D(n=5) ; *$ indicates significant $(p<0.0001)$ effect of fasting by two-way ANOVA. 

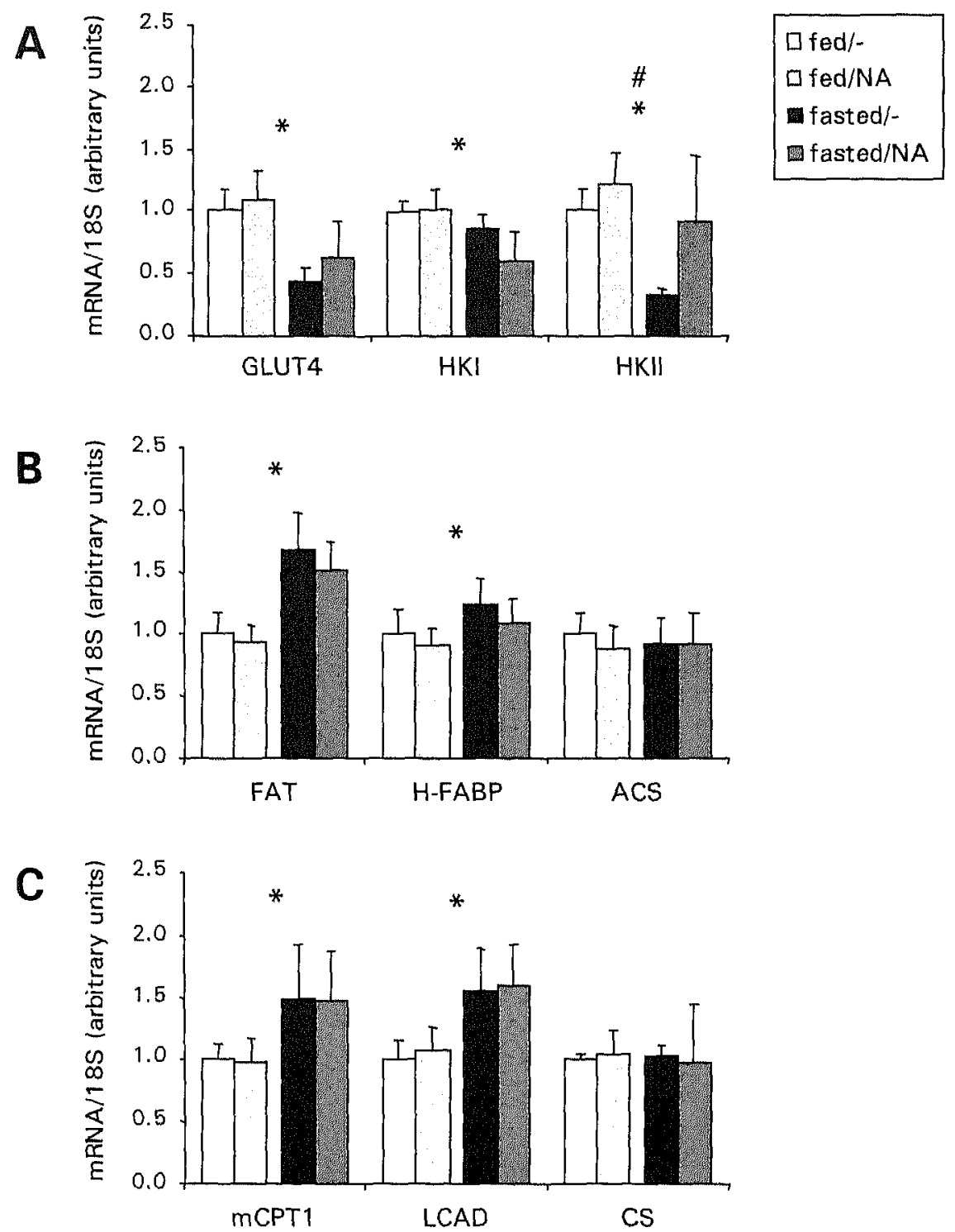

Figure 6.3 Effects of $46 \mathrm{~h}$ fasting and $8 \mathrm{~h}$ nicotinic acid treatment on mRNA levels of proteins involved in glucose utilisation (A), fatty acid transport and activation (B), mitochondrial fatty acid handling, and the citric acid cycle (C). MRNA levels of the glucose transporter GLUT4, hexokinase (HK) I and II, fatty acid translocase/CD36 (FAT), heart-type fatty acid-binding protein (H-FABP), acylCoA synthetase (ACS), muscle-type carnitine palmitoyl-transferase 1 (mCPT1), long-chain acyl-CoA dehydrogenase (LCAD), and citrate synthase (CS) were determined by northern blotting and normalised to $18 \mathrm{~S}$ ribosomal RNA levels to correct for possible loading differences. The level of expression of the control group (fed/-) was arbitrarily set at 1.0. Data are presented as means $\pm S D$ $(n=5) ;{ }^{*}$ indicates significant $(p<0.05)$ effect of fasting, and \# indicates significant $(p<0.001)$ effect of nicotinic acid by two-way ANOVA. 
To investigate whether the changes in enzyme activity and protein content were related to changes in mRNA levels of metabolic proteins northern blotting was applied. mRNA levels of both cardiac glucose transporters GLUT1 and GLUT4 and of the hexokinase isozymes hexokinase I and II (HKI and HKII) were determined. Quantification of GLUT1 appeared not to be possible, since the signal was below the level of detection (data not shown). mRNA levels of the insulin-sensitive glucose transporter GLUT4 and the glycolytic enzyme HKII were $56 \%$ and $67 \%$ lower in the fasted group than in the fed group, respectively (Fig. 6.3A). The expression of HKI was slightly but significantly decreased in hearts of fasted animals. In contrast, the mRNA levels of proteins that are involved in fatty acid transport and metabolism increased up to 1.7-fold in the cardiac muscle of fasted animals, the only exception being acyl-CoA synthetase (ACS), the level of which did not change significantly (Figs. 6.3B and 6.3C). The expression of CS was also not affected by fasting (Fig. 6.3C).

Whereas all above mentioned proteins are involved in the transport and conversion of substrates in order to produce energy, uncoupling proteins (UCPs) are thought to dissipate energy by uncoupling oxidative phosphorylation $[8,10,12]$. As opposed to UCP-2, the expression of UCP-3 was markedly induced in heart muscle after $46 \mathrm{~h}$ of fasting (Fig. 6.4).

As the fatty acid-activated transcription factors PPARs play a regulatory role in lipid metabolism [7,25], the mRNA levels of the PPAR isoforms PPAR $\alpha$ and PPAR $\beta / \delta$ were also measured. Interestingly, the expression of both PPAR subtypes was found to be more than $25 \%$ decreased in the rat hearts by $46 \mathrm{~h}$ fasting (Fig. 6.5).

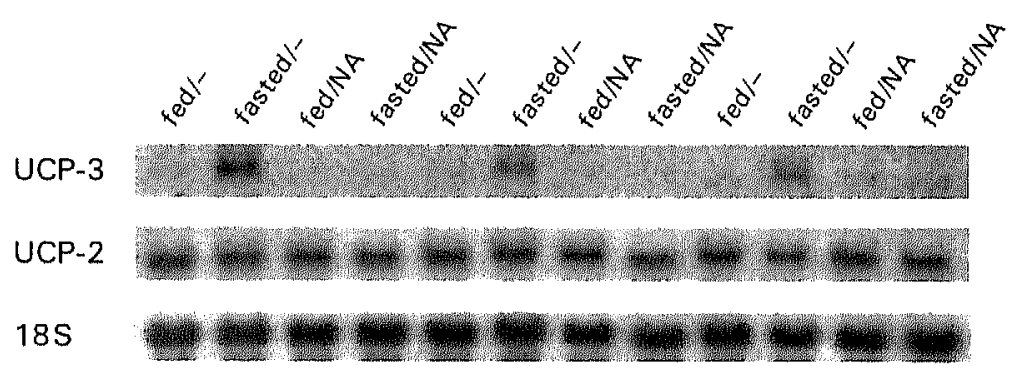

Figure 6.4 Representative northern blot, showing the effects of $46 \mathrm{~h}$ fasting and $8 \mathrm{~h}$ nicotinic acid treatment on mRNA expression of the uncoupling proteins UCP-3 and UCP-2. The $18 \mathrm{~S}$ ribosomal RNA signal demonstrates possible loading differences.

\section{Effects of nicotinic acid treatment}

In order to examine in which way the heart responds to changes in circulating fatty acids, in a subset of experiments fed and fasted rats were treated with the anti-lipolytic agent nicotinic acid for 8 hours. As anticipated [15], nicotinic acid reduced fatty acid levels in both fed and fasted rats, but did not affect serum glucose concentrations (Table 6.1). 


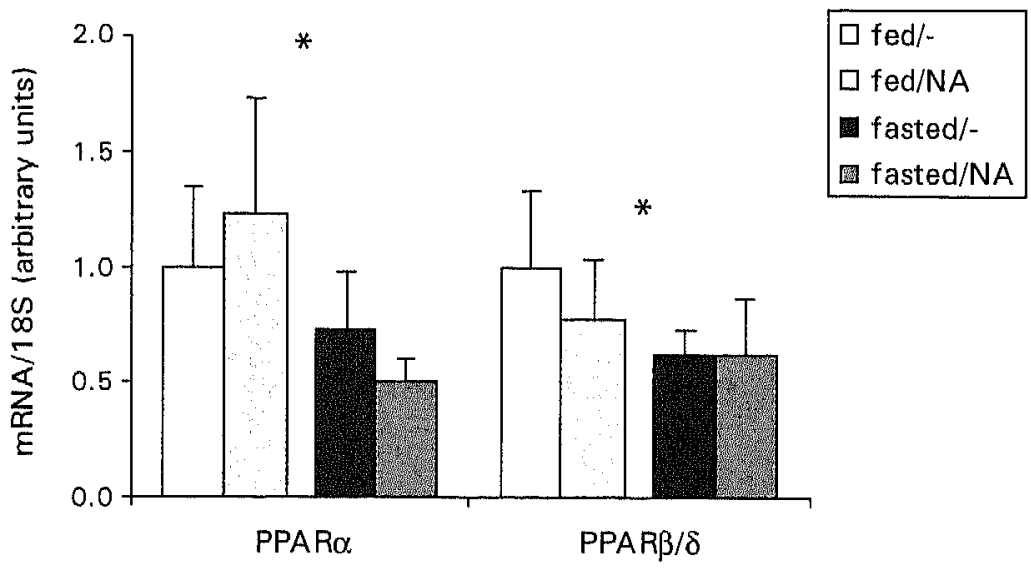

Figure 6.5 Effects of $46 \mathrm{~h}$ fasting and $8 \mathrm{~h}$ nicotinic acid treatment on cardiac mRNA expression of the transcription factors PPAR $\alpha$ and PPAR $\beta / \delta$. To correct for possible loading differences, mRNA levels were normalised to corresponding $18 \mathrm{~S}$ ribosomal RNA signals. The level of expression of the control group (fed/-) was arbitrarily set at 1.0. Data are presented as means $\pm \operatorname{SD}(n=5)$; indicates significant $(p<0.05)$ effect of fasting by two-way ANOVA.

Nicotinic acid treatment per se did not affect the fasting-induced changes in the expression of the majority of genes coding for proteins involved in cardiac substrate transport and metabolism (Fig. 6.3). However, nicotinic acid treatment partially restored HKII mRNA levels in hearts of fasted animals (Fig. 6.3A). In line with the absence of changes in mRNA levels, neither protein contents nor enzyme activities were affected by nicotinic acid treatment, with exception of CS, the activity of which slightly though significantly increased (Figs. 6.1 and 6.2).

In contrast to UCP-2, nicotinic acid treatment affected the expression of UCP-3 profoundly (Fig. 6.4). When the animals were treated with nicotinic acid for $8 \mathrm{~h}$ the fasting-induced increase of UCP-3 mRNA in the heart was completely abolished. As far as the fatty acid-activated transcription factors are concerned, both PPAR $\alpha$ and PPAR $\beta / \delta$ mRNA levels were not significantly altered (Fig. 6.5).

\section{Discussion}

\section{Fasting-induced changes in the heart}

During fasting whole body metabolism dramatically changes. Along with alterations in plasma hormone levels the concentration of circulating fatty acids substantially increases and glucose levels decline. In this study, the heart is shown to adapt to these changes in substrate supply by modulating the expression of a variety of genes involved in cardiac glucose and fatty acid transport and metabolism. Overall, mRNA levels of proteins involved in cellular glucose transport and metabolism declined in 
myocardial tissue of fasted rats, whereas the expression of the majority of genes encoding proteins involved in cellular fatty acid transport and metabolism increased. These changes were accompanied by altered protein contents or enzyme activities of a variety of proteins involved in substrate transport and metabolism.

Previous studies already showed that differences in nutritional state lead to changes in cardiac substrate utilisation $[9,17,19,30,41]$. The question whether this was merely a mass effect (less glucose, more fatty acids supplied via the blood) or due to intrinsic changes in cardiac metabolism has previously been tackled by using isolated hearts of fed and fasted animals. These studies consistently reported a shift in substrate preference from glucose to fatty acids in isolated hearts of fasted animals $[9,17,19,30,41]$, suggesting that intrinsic changes in cardiac metabolism are involved. Indeed, scattered data are available demonstrating that mRNA levels of mCPT1 [42] and acyl-CoA dehydrogenases [18] increased and GLUT4 gene expression [6,38] decreased in the heart during fasting. The present study extends these findings and shows that the shift in cardiac substrate preference can be attributed to a reciprocal adjustment at the level of gene expression of a variety of transport proteins and enzymes. Thus, mRNA levels of GLUT4, HKI and HKII, proteins involved in glucose transport and metabolism, are downregulated, whereas the expression of genes coding for FAT/CD36, H-FABP, mCPT1 and LCAD, proteins involved in fatty acid transport and metabolism, increases in myocardial tissue of the fasted rat.

\section{Fatty acids}

The factors that are responsible for this metabolic remodelling remain to be elucidated. Since circulating fatty acid concentrations are markedly increased in fasted animals, and fatty acids have been shown to act as signalling molecules [32], it is tempting to speculate that these substrates are implicated in the remodelling process. This speculation is supported by previous in vitro observations. We found that the mere addition of fatty acids to the culture medium of neonatal cardiomyocytes lead to a selective and co-ordinate induction of the expression of proteins involved in fatty acid uptake and metabolism, thereby showing that fatty acids themselves are able to modulate gene expression in cardiac myocytes [34].

To obtain more insight into the role of fatty acids per se in the fasting-induced changes in cardiac gene expression, nicotinic acid was administered to reduce the serum fatty acid concentrations in rats. Decreasing circulating fatty acid concentrations in fasted rats by an $8 \mathrm{~h}$ nicotinic acid treatment only affected the expression of some of the genes investigated (HKII, UCP-3). The mRNA levels of the majority of the metabolic genes did not alter when circulating fatty acid levels were reduced. At first sight, this would argue against a predominant role of circulating fatty acids in the modulation of the expression of these cardiac genes. It should, however, be taken into account that the half-lives of these mRNAs may be substantially longer than the duration of nicotinic acid treatment. For instance, the half-life for FAT/CD36 mRNA was estimated to be approximately $13 \mathrm{~h}$ in cultured adipocytes [27]. Accordingly, it is likely that the duration of the nicotinic acid treatment was simply too short to show significant effects on cardiac content of these mRNAs. 


\section{Uncoupling proteins}

Cardiac UCP-3 mRNA levels, which are very low in rats fed ad libitum, markedly increase during fasting, an induction which is completely reversed by nicotinic acid treatment. This strongly suggests that UCP-3 expression in the heart, a highly oxidative muscle, is regulated by fatty acids. This is consistent with our previous findings in soleus muscle, an oxidative muscle as well, in which we found UCP-3 expression to be dependent on fatty acid supply $[22,24]$. Interestingly, this analogy does not hold for UCP-2. Similar to UCP-3, this isoform is clearly responsive to fatty acids in soleus muscle, but in cardiac muscle it is marginally responsive to changes in circulating fatty acid levels. The reason for this difference in behaviour is incompletely understood.

Since uncoupling proteins uncouple ATP synthesis from the respiratory chain, UCPS are thought to dissipate energy. However, the exact biological functions of UCP-3 and UCP-2 are still largely unknown. Many functional roles for these uncoupling proteins have been proposed, one of which is participation in the regulation of lipid metabolism $[3,23]$. The notion that UCP-3 and UCP-2 respond to fatty acids in oxidative but not in glycolytic muscles $([22,24]$ and present study) and that genes coding for proteins involved in fatty acid metabolism are responsive to fatty acids $[4,34]$ further supports the latter hypothesis. In this respect it is striking that both UCP-3 and UCP-2 are induced in cultured neonatal rat cardiomyocytes after exposure to fatty acids for $48 \mathrm{~h}$ (K.A.J.M. van der Lee and $M$. van Bilsen, unpublished observations) [35].

\section{Peroxisome proliferator-activated receptors}

In cultured neonatal cardiomyocytes the fatty acid-induced upregulation of the expression of genes coding for fatty acid-handling proteins could be mimicked through the addition of a selective PPAR $\alpha$ ligand, suggesting that the effect of fatty acids is PPAR-mediated [34]. Studies using PPAR $\alpha$ knock-out mice indeed showed that the fasting-induced upregulation of genes involved in lipid metabolism is blunted in livers $[11,13]$ as well as in hearts [14] of these mice.

In mouse liver $24 \mathrm{~h}$ fasting was associated with a substantial increase in the expression of PPAR $\alpha$ [11]. The present study indicates that in rat heart mRNA levels of both PPAR $\alpha$ and PPAR $\beta / \delta$ actually declined as a result of fasting. Species differences as well as tissue differences may explain this discrepancy. Moreover, the present data suggest that the upregulation of PPARs per se is not a prerequisite for the induction of genes involved in lipid metabolism. In this respect it is noteworthy that recent findings indicate that, in addition to PPAR abundance, transcriptional activity is also dependent on the presence of auxiliary proteins that act as coactivator or corepressor, and on the phosphorylation state of PPAR $\alpha$ [7,33]. Further studies are required to disclose as to whether the latter mechanisms are operational in PPAR functioning in hearts of fasted rats. 


\section{Involvement of other factors}

Cardiac mRNA levels of proteins involved in glucose transport and metabolism are markedly reduced in the fasted rat. So far, it seems quite unlikely that the decline in mRNA levels of the glucose transporter GLUT4 and of hexokinase II involves PPAR. The observation that $W y-14,643$, a PPAR $\alpha$ specific ligand, was unable to affect the expression of GLUT4 in cultured cardiac myocytes are in support of this notion [34]. Nonetheless, recent findings by $\mathrm{Wu}$ and colleagues $[39,40]$ demonstrated that the expression of the pyruvate dehydrogenase kinase isozyme PDK4, which phosphorylates and, hence, inactivates the PDH complex, is rapidly induced in skeletal and cardiac muscle of diabetic and fasted animals. Furthermore these investigators showed that PDK4 expression in skeletal muscle is also induced by administration of the specific PPAR $\alpha$ ligand $W y-14,643$ [39]. The latter findings suggest that PPARs are able to modulate glucose oxidation, albeit in an indirect manner.

Finally, it is unclear why, unlike other fatty acid metabolic genes, ACS is not upregulated in the cardiac muscle during fasting. In vitro, ACS mRNA levels do increase after exposure of neonatal cardiomyocytes to fatty acids and ACS clearly behaves as a PPAR $\alpha$-responsive gene [34]. In this context it is worth mentioning that the in vivo administration of PPAR ligands to rats did not affect the expression of ACS in the heart, whereas in the liver a marked upregulation was observed $[16,26]$. Taken together these findings strongly suggest that, in addition to PPARs, other factors also play a role in the regulation of metabolic genes in the heart. During fasting circulating levels of hormones, like insulin, glucocorticoids and thyroid hormone, change as well, and effects of these hormones cannot be excluded.

In summary, the present study demonstrates that changes in cardiac metabolism as found during severe fasting have their origin in altered metabolic gene expression in the heart.

\section{Acknowledgements}

The authors are indebted to Dr. B. Gerritse for statistical advice. The work of S.S., J.S., and A.G.D. was supported by grants no. 31.057129 .991 and 3200.061687 of the Swiss National Science Foundation. The research of MvB was funded by grants 97.092 and D98.015 of the Netherlands Heart Foundation.

\section{References}

1. Bergmeyer HU, Gawehn K, and Grassl M (1974). 3-Hydroxyacyl-CoA dehydrogenase. In Methods of enzymatic analysis. Bergmeyer HU, Eds. Verlag Chemie $\mathrm{GmbH}$, Weinheim, 474

2. Bergmeyer HU, Gawehn K, and Grassl M (1974). Hexokinase. In Methods of enzymatic analysis. Bergmeyer $\mathrm{HU}$, Eds. Verlag Chemie $\mathrm{GmbH}$, Weinheim, 473 
3. Boss $O$, Bobbioni-Harsch E, Assimacopoulos-Jeannet $F$, Muzzin P, Munger R, Giacobino J-P, and Golay $A$ (1998). Uncoupling protein-3 expression in skeletal muscle and free fatty acids in obesity. Lancet 351, 1933

4. Brandt JM, Djouadi F, and Kelly DP (1998). Fatty acids activate transcription of the muscle carnitine palmitoyltransferase 1 gene in cardiac myocytes via the peroxisome proliferatoractivated receptor $\alpha$. J Biol Chem 273, 23786-23792

5. Brass EP and Hoppel CL (1978). Carnitine metabolism in the fasting rat. J Biol Chem 253, 2688-2693

6. Camps M, Castello A, Munoz P, Monfar M, Testar X, Palacin M, and Zorzano A (1992). Effect of diabetes and fasting on GLUT-4 (muscle/fat) glucose-transporter expression in insulinsensitive tissues. Heterogeneous response in heart, red and white muscle. Biochem / 282, 765-772

7. Desvergne B and Wahli W (1999). Peroxisome proliferator-activated receptors: nuclear control of metabolism. Endocr Rev 20, 649-688

8. Fleury $C$, Neverova $M$, Collins S, Raimbault S, Champigny O, Levi-Meyrueis C, Bouillaud $F$, Seldin MF, Surwit RS, Ricquier D, and Warden CH (1997). Uncoupling protein-2; a novel gene linked to obesity and hyperinsulinemia. Nature Genet 15, 269-272

9. Ghezzi C, Dubois F, Mathieu JP, Cand F, Comet $M$, and Cuchet P (1990). Effect of short-term fasting on [1231] iodohexadecenoic acid metabolism in the isolated perfused rat heart. Validation of mathematical model by comparison with experimental measurements. Arch Int Physiol Biochim 98, 269-281

10. Gong D-W, He $Y$, Karas $M$, and Reitman $M$ (1997). Uncoupling protein-3 is a mediator of thermogenesis regulated by thyroid hormone, $\beta 3$-adrenergic agonists, and leptin. / Biol Chem $272,24129-24132$

11. Kersten S, Seydoux J, Peters JM, Gonzalez FJ, Desvergne B, and Wahli W (1999). Peroxisome proliferator-activated receptor $\alpha$ mediates the adaptive response to fasting. I Clin Invest 103, 1489-1498

12. Klingenberg $M$ and Huang S-G (1999). Structure and function of the uncoupling protein from brown adipose tissue. Biochim Biophys Acta 1415, 271-296

13. Kroetz $D L$, Yook $P$, Costet $P$, Bianchi $P$, and Pineau $T$ (1998). Peroxisome proliferatoractivated receptor $\alpha$ controls the hepatic CYP4A induction adaptive response to starvation and diabetes. / Biol Chem 273, 31581-31589

14. Leone TC, Weinheimer C], and Kelly DP (1999). A critical role for the peroxisome proliferatoractivated receptor $\alpha(P P A R \alpha)$ in the cellular fasting response: The PPAR $\alpha$-null mouse as a model of fatty acid oxidation disorders. Proc Natl Acad Sci USA 96, 7473-7478

15. Lowell BB and Goodman MN (1987). Protein sparing in skeletal muscle during prolonged starvation. Dependence on lipid fuel availability. Diabetes 36, 14-19

16. Martin G, Schoonjans K, Lefebvre A-M, Staels B, and Auwerx J (1997). Coordinate regulation of the expression of the fatty acid transport protein and acyl-CoA synthetase genes by PPAR $\alpha$ and PPARy activators. / Biol Chem 272, 28210-28217

17. Montessuit C, Papageorgiou I, Tardy I, and Lerch R (1996). Effect of nutritional state on substrate metabolism and contractile function in postischemic rat myocardium. Am / Physiol 271, $\mathrm{H} 2060-\mathrm{H} 2070$

18. Nagao M, Parimoo B, and Tanaka K (1993). Developmental, nutritional, and hormonal regulation of tissue-specific expression of the genes encoding various acyl-CoA dehydrogenases and $\alpha$-subunit of electron transfer flavoprotein in rat. / Biol Chem 268, 2411424124

19. Opie LH, Evans JR, and Shipp JC (1963). Effect of fasting on glucose and palmitate metabolism of perfused rat heart. Am / Physiol 205, 1203-1208

20. Pelsers MMAL, Lutgerink JT, van Nieuwenhoven FA, Tandon NN, van der Vusse GJ, Arends JW, Hoogenboom HR, and Glatz JFC (1999). A sensitive immunoassay for rat fatty acid translocase (CD36) using phage antibodies selected on cell transfectants: abundant presence 
of fatty acid translocase/CD36 in cardiac and red skeletal muscle and up-regulation in diabetes. Biochem / 337, 407-414

21. Reaven GM, Hollenbeck $C_{t}$ Jeng $C Y$, Wu MS, and Chen YD (1988). Measurement of plasma glucose, free fatty acid, lactate, and insulin for $24 \mathrm{~h}$ in patients with NIDDM. Diabetes 37 , 1020-1024

22. Samec S, Seydoux \}, and Dulloo AG (1998). Interorgan signaling between adipose tissue metabolism and skeletal muscle uncoupling protein homologs. Is there a role for circulating free fatty acids? Diabetes 47, 1693-1698

23. Samec S, Seydoux J, and Dulloo AG (1998). Role of UCP homologues in skeletal muscles and brown adipose tissue: mediators of thermogenesis or regulators of lipids as fuel substrate? FASEB / 12, 715-724

24. Samec S, Seydoux J, and Dulloo AG (1999). Skeletal muscle UCP3 and UCP2 gene expression in respone to inhibition of free fatty acid flux through mitochondrial $\beta$-oxidation. Eur / Physiol $438,452-457$

25. Schoonjans K, Staels B, and Auwerx J (1996). The peroxisome proliferator activated receptors (PPARs) and their effects on lipid metabolism and adipocyte differentiation. Biochim Biophys Acta 1302, 93-109

26. Schoonjans K, Staels B, Grimaldi $P$, and Auwerx J (1993). Acyl-CoA synthetase mRNA expression is controlled by fibric-acid derivatives, feeding and liver proliferation. Eur I Biochem 216, 615-622

27. Sfeir Z, lbrahimi A, Amri E, Grimaldi P, and Abumrad N (1997). Regulation of FAT/CD36 gene expression: further evidence in support of a role of the protein in fatty acid binding/transport. Prostaglandins Leukot Essent Fatty Acids 57, 17-21

28. Shepherd D and Garland PB (1969). Citrate synthase from rat liver. Methods Enzymol 13, 1116

29. Taegtmeyer $H$ (1994). Energy metabolism of the heart: from basic concepts to clinical applications. Curr Probl Cardiol 19, 59-113

30. Vahouny GV, Katzen R, and Entenman C (1967). Myocardial metabolism. II. Role of nutritional state on palmitate and glucose oxidation by isolated perfused hearts. Biochim Biophys Acta 137, 181-183

31. Van Bilsen $M$, van der Lee KAJM, and van der Vusse GJ (1999). Long-chain fatty acids and signal transduction in the cardiac muscle cell. In Cardiovascular specific gene expression. Doevendans PA, Reneman RS, and van Bilsen M, Eds. Kluwer Academic Publishers, Dordrecht, the Netherlands, 257-268

32. Van Bilsen M, van der Vusse GJ, and Reneman RS (1998). Transcriptional regulation of metabolic processes: implications for cardiac metabolism. Eur / Physiol 437, 2-14

33. Van der Lee KAJM, de Brouwer KFJ, van der Vusse GJ, and van Bilsen $M$ (2000). Fatty acidregulated gene expression in the heart: Involvement of peroxisome proliferator-activated receptors. Recent Res Devel Lipids 4, 25-38

34. Van der Lee KAJM, Vork MM, de Vries JE, Willemsen PHM, Glatz JFC, Reneman RS, van der Vusse G), and van Bilsen $M(2000)$. Long-chain fatty acid-induced changes in gene expression in neonatal cardiac myocytes. / Lipid Res 41, 41-47

35. Van der Lee KAJM, Willemsen PHM, van der Vusse GJ, and van Bilsen $M(2000)$. Effects of fatty acids on uncoupling protein-2 expression in the rat heart. FASEB / 14, 495-502

36. Van der Vusse GJ, Glatz JFC, Stam HCG, and Reneman RS (1992). Fatty acid homeostasis in the normoxic and ischemic heart. Physiol Rev 72, 881-940

37. Wodzig KW, Pelsers MM, van der Vusse G), Roos W, and Glatz JF (1997). One-step enzymelinked immunosorbent assay (ELISA) for plasma fatty acid-binding protein. Ann Clin Biochem 34, 263-268

38. Woloschak M, Shen-Orr Z, LeRoith D, and Roberts CT, Jr. (1993). Nutritional regulation of insulin-sensitive glucose transporter gene expression in rat cardiac muscle. Proc Soc Exp Biol Med 203, 172-174 
39. Wu P, Inskeep K, Bowker-Kinley MM, Popov KM, and Harris RA (1999). Mechanism responsible for inactivation of skeletal muscle pyruvate dehydrogenase complex in starvation and diabetes. Diabetes 48, 1593-1599

40. Wu P, Sato J, Zhao Y, Jaskiewicz J, Popov KM, and Harris RA (1998). Starvation and diabetes increase the amount of pyruvate dehydrogenase kinase isoenzyme 4 in rat heart. Biochem J 329, 197-201

41. Yaffee S, Gold A, and Sampugna J (1980). Effects of prolonged starvation on plasma free fatty acid levels and fatty acid composition of myocardial total lipids in the rat. I Nutr 110, 24902496

42. Yu G-S, Lu Y-C, and Gulick T (1998). Co-regulation of tissue-specific alternative human carnitine palmitoyltransferase $\mathrm{lb}$ gene promoters by fatty acid enzyme substrate. / Biol Chem 273, 32901-32909 


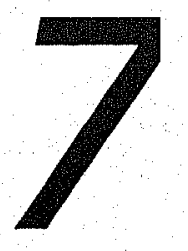

General discussion 


\section{Fatty acid-induced metabolic remodelling of the heart}

For the production of energy the heart is able to use a variety of substrates, including glucose, fatty acids and lactate. Under certain (patho-)physiological conditions, like perinatal development, fasting, and diabetes, the utilisation of substrates by the cardiac muscle appears to depend largely on the availability of these compounds in the circulation. Consequently, the heart may be considered as an omnivorous organ equipped with the biochemical machinery to digest whatever is supplied. As described in chapter 1, fatty acid and glucose metabolism can be regulated at shortterm basis by various mechanisms, including negative feedback loops involving metabolic end products and phosphorylation of rate-governing enzymes. At the long term, i.e. hours to days, the amount of enzymes and transport proteins involved in metabolic pathways can also be altered by adjustment at the transcriptional level. In this thesis the metabolic plasticity of the heart at the level of gene expression has been investigated, a process that we would like to refer to as "metabolic remodelling".

Several studies already demonstrated that fatty acids are able to alter the expression of genes encoding proteins involved in intracellular fatty acid transport and metabolism in various cell types, including adipocytes and hepatocytes $[8,17,32]$. Since fatty acids are the major substrates for the heart and the heart is able to adjust substrate utilisation to substrate availability, we hypothesised that fatty acids themselves are able to induce changes in cardiac gene expression in favour of fatty acid metabolism. This hypothesis was tested using various models and conditions.

Using in vitro models, in which cultured neonatal rat cardiomyocytes and embryonic rat heart-derived $\mathrm{H} 9 \mathrm{c} 2$ cells were exposed to fatty acids, it was demonstrated that fatty acids are indeed able to modulate metabolic gene expression (Chapter 3 and 4). In general, fatty acids substantially increased mRNA levels of proteins involved in fatty acid-handling, and significantly decreased the expression of genes coding for proteins involved in glucose transport and metabolism. In addition, we showed for neonatal cardiac myocytes that the rise in the expression of fatty acidmetabolic genes is accompanied with an increased capacity of these cells to oxidise fatty acids (Chapter 3), indicating that the changes in gene expression have physiological implications as well. Thus, fatty acids seem to be able to stimulate their own metabolism by means of a feedforward mechanism at the level of gene expression.

The collected data implicate that under in vivo circumstances, in which circulating fatty acid levels are elevated, cardiac $\beta$-oxidation may increase not only due to a mass effect of the oxidisable substrate but also through an upregulation of genes coding for fatty acid-handling proteins. When comparing mRNA levels of various proteins involved in fatty acid transport and metabolism in hearts of rats either fed ad libitum or fasted for $46 \mathrm{~h}$, a condition associated with a rise in circulating fatty acid levels and enhanced cardiac fatty acid utilisation $[34,38]$, we found that the mRNA levels were indeed elevated in the fasted rat hearts (Chapter 6 ). Together, these data indicate that 
metabolic plasticity at the level of gene expression is an important regulatory mechanism for the in situ heart as well.

In this chapter, the molecular mechanism likely to mediate the fatty acid-induced changes in cardiac gene expression is discussed. Furthermore, the physiological as well as pathophysiological significance of fatty acid-regulated gene expression in the heart is deliberated. Finally, recommendations for future investigations are given.

\section{Molecular mechanisms involved in cardiac fatty acid-modulated gene expression}

The mechanism by which fatty acids modulate the expression of metabolic genes in the heart is incompletely understood. At this moment, the majority of studies has focussed on the peroxisome proliferator-activated receptors (PPARs), known to play a role in the regulation of whole-body and cellular lipid metabolism (reviewed in $[14,46])$. PPAR $\alpha$ is involved in the regulation of lipid catabolism and PPAR $\gamma$ in the differentiation of adipocytes. Recently, PPAR $\beta / \delta$ has also been suggested to be a regulator of adipogenesis $[4,5]$. Whether PPAR $\beta / \delta$ has a specific function in cardiac lipid metabolism is, however, uncertain.

In this thesis, studies on the molecular mechanism of cardiac fatty acid-mediated gene expression also focussed on PPARs. Using cultured neonatal rat cardiomyocytes and the heart-derived $\mathrm{H} 9 \mathrm{C} 2$ cell line, it was demonstrated that PPAR isoform-specific ligands could mimic the fatty acid-induced upregulation of fatty acid metabolic genes provided that the respective PPAR isoforms are present (Chapters 3 and 4). Thus, the lack of effects of ciglitazone, a PPAR $\gamma$-specific ligand, corroborates the absence of PPAR $\gamma$ in heart muscle cells. The PPAR $\alpha$-specific ligand $W y-14,643$ increased gene expression in cultured neonatal cardiomyocytes but not in $\mathrm{H} 9 \mathrm{c} 2$ cells, which lack PPAR $\alpha$. The PPAR $\beta / \delta$-specific agonist L-165041 was able to induce the expression of fatty acid metabolic genes in both cell types, although the effect was not as marked as found with the PPAR $\alpha$ ligand. Whether PPAR $\beta / \delta$ really plays a role in cardiac metabolic gene expression should be investigated in more detail. Experiments using models in which PPAR $\beta / \delta$ is inactivated or "knocked-out" should provide additional information about the function of this PPAR-subtype in cardiac gene expression. In this regard, the recently developed PPAR $\beta / \delta$ deficient mouse [40] may be a useful in vivo model. Additional evidence for a role of PPAR $\alpha$ in cardiac metabolic gene expression came from studies using PPAR $\alpha(-/-)$ mice [26,57]. These studies demonstrated that constitutive mRNA and protein levels of several enzymes involved in mitochondrial $\beta$-oxidation were lower in hearts of PPAR $\alpha$ null mice than in hearts of wild-type mice [57]. Moreover, in the absence of PPAR $\alpha$ the response of the heart to fasting was altered, i.e. the expression of genes coding for proteins involved in fatty acid metabolism was not induced during fasting [26].

It should be realised, however, that the studies presented in this thesis do not provide direct evidence that PPARs are actually mediating the effects of fatty acids. It has only been demonstrated that artificial PPAR ligands are able to mimic the effects 
of fatty acids (Chapters 3 and 4). PPARs exert their effect through interaction with a PPAR-responsive element (PPRE) in the upstream regulatory region of the gene concerned (Fig. 2.3). Therefore, demonstration that fatty acids increase gene expression via PPREs will provide additional evidence for a role of PPARs in fatty acid-modulated gene expression. Indeed, such evidence was obtained in pilot experiments in which neonatal rat cardiomyocytes were transfected with a luciferase expression vector containing a PPRE in its promoter region. Exposure of the transfected cells to fatty acids resulted in an increased activity of luciferase, which did not occur in cells transfected with a control vector lacking PPRE (K.A.J.M. van der Lee and $M$. van Bilsen, unpublished observations). Moreover, an elegant study performed in the laboratory of D.P. Kelly demonstrated that in neonatal rat cardiomyocytes fatty acids activate transcription of the muscle-type carnitine palmitoyl transferase 1 (mCPT1) via a PPRE in the promoter region of the mCPT1 gene, with which PPAR $\alpha$ was shown to interact [6]. Collectively, these findings indicate that PPAR $\alpha$ indeed plays a role in fatty acid-mediated gene expression in the heart.

As far as the function of PPARs in vivo is concerned, it is striking that treatment of adult rats with fenofibrate, a PPAR $\alpha$ ligand, does not affect gene expression of the fatty acid transport protein (FATP) and acyl-CoA synthetase (ACS) in the heart, in contrast to liver $[31,47]$. Treatment of mice with ciprofibrate, another activator of PPAR $\alpha$, did not alter contents of mitochondrial or peroxisomal enzymes involved in cardiac fatty acid oxidation either [10]. These data are hard to reconcile with the notion that in the adult heart the expression of metabolic genes is mediated by PPAR $\alpha$. Whether the lack of effects of PPAR $\alpha$ agonists on gene expression in the adult heart, in contrast to cultured neonatal cardiomyocytes, can be ascribed to confounding factors in in vivo models (e.g. reduced bioavailability of PPAR agonists), or reflects differences between adult and newborn hearts (e.g. different levels of co-repressors or co-activators of PPAR), remains to be determined. Interestingly, a recent study demonstrated that treatment of weanling rats with clofibrate, an agonist of $P P A R \alpha$, actually increases the expression of FATP, medium- and long-chain acyl-CoA dehydrogenase (MCAD and LCAD), and the peroxisomal enzyme acyl-CoA oxidase in the heart [39], indicating that the developing heart is responsive to PPAR $\alpha$ indeed. Further clues for the role of PPARs in the expression of metabolic genes in the adult heart may be provided by studying the effects of PPAR subtype-specific ligands in isolated adult cardiomyocytes, in addition to neonatal cardiomyocytes.

It is basically unknown whether PPARs are the only possible mediators of fatty acid-induced changes in metabolic gene expression in the heart. It is conceivable that other transcription factors may be activated or inhibited by fatty acids or by fatty acid metabolites. For example, long-chain fatty acids and acyl-CoAs have been reported to bind other nuclear hormone receptors, among which the thyroid hormone receptor and the hepatocyte nuclear factor HNF-4 $[18,19,27,58]$. Finally, it should be kept in mind that modulation of cardiac gene expression by fatty acids does not necessarily involve direct interaction between fatty acids and transcription factors. Fatty acids may modulate signalling pathways that lead to alterations in the rate of gene expression. For instance, fatty acids have been shown to affect the activity of protein kinase $C$ [24], and may affect the activity of various proteins through protein-acylation. 
Moreover, the possibility exists that fatty acids not only modulate gene transcription but also mRNA stability, resulting in altered mRNA levels as well. Fatty acids have already been shown to enhance the stability of CPT1 mRNA in hepatocytes [8]. In addition, it has to be taken into account that fatty acids are precursor molecules for eicosanoids, known modulators of gene expression $[1,25,37]$. Whether these mechanisms are actually playing a role in the heart is basically unknown and remains to be investigated.

\section{Physiological significance of substrate-mediated gene expression}

The significance of the finding that fatty acids are able to regulate their metabolic fate at the level of gene expression in cardiac muscle cells can be illustrated by the metabolic adaptation of the heart during various physiological conditions. Metabolic remodelling of the heart already occurs soon after birth. When suckling starts, circulating fatty acid levels elevate and the utilisation of fatty acids by the heart increases [16]. At the same time, the expression of several genes coding for fatty acidhandling proteins increases $[22,56]$. Another example in which metabolic gene expression is altered in the heart is fasting. As described in chapter 6 , the heart adapts to this condition of an increased fatty acid supply by modulating gene expression of proteins involved in fatty acid transport and metabolism. The ability of fatty acids to alter cardiac gene expression and the fact that metabolic remodelling in hearts of newborn and fasted animals is accompanied with elevated fatty acid levels in blood suggests that also in vivo under physiological circumstances fatty acids fulfil a role in the regulation of cardiac gene expression.

Since the heart can be considered as an omnivorous organ and fatty acids are able to increase cardiac fatty acid metabolism at the molecular level, it is tempting to speculate that other substrates, like glucose, are able to modulate cardiac metabolic gene expression as well. Indeed, in liver and adipose tissue glucose has been shown to upregulate genes encoding lipogenic and glycolytic enzymes [15]. Moreover, carbohydrate-responsive elements have been localised in the promoter region of the liver-type pyruvate kinase gene and of the spot 14 (S14) gene that encodes a protein thought to be involved in the regulation of lipogenesis $[48,52]$. The transcription factor known to interact with the carbohydrate responsive elements, the so-called upstream stimulatory factor (USF), is present in the heart as well [35,59], which increases the possibility that glucose may actually influence cardiac gene expression.

In this thesis, the ability of fatty acids to modulate the expression of genes encoding proteins involved in cardiac metabolism is demonstrated. The question remains to be answered whether all genes regulated by fatty acids are actually coding for proteins involved in substrate metabolism or whether fatty acids are able to alter the expression of cardiac genes involved in other functions as well. For other cell types it has been shown that fatty acids can indeed change the expression of genes that do not code for metabolic proteins. The finding that in preadipose cells fatty acids induce the expression of angiotensinogen [45] is of special interest. The presence of a local renin-angiotensin system in the heart, which is likely to play a role in the 
development of cardiac hypertrophy [53], and the potential ability of fatty acids to affect this system, suggests that fatty acids could play a role in the development of cardiac disease. To examine in full detail which cardiac genes are actually regulated by fatty acids, differential display-like techniques and micro-arrays are useful tools.

\section{Role of fatty acid-mediated gene regulation in cardiac pathophysiology}

The ability of fatty acids to modulate cardiac gene expression may have consequences for the pathogenesis of cardiac diseases. As stated previously, cardiac metabolism alters during several pathophysiological conditions. These conditions can roughly be subdivided into (a) conditions in which the effect on cardiac metabolism is secondary to disorders outside the heart per se, like diabetes, and (b) conditions in which the change in metabolism is one of the hallmarks of the cardiac disease, like cardiac hypertrophy and heart failure.

During uncontrolled diabetes whole-body carbohydrate metabolism is disturbed, and, as a consequence, the contribution of fatty acids to cardiac energy production is increased (reviewed in [28]). In hearts of streptozotocin-induced diabetic rats, this is associated with decreased mRNA levels of the glucose transporters GLUT1 and GLUT4, and of hexokinase $\|[7,13]$ (P.H.M. Willemsen and M. van Bilsen, unpublished observations). In contrast, the expression of the fatty acid-transporting proteins FAT, FATP, plasmalemmal FABP, and cytosolic H-FABP tended to increase during diabetes [56]. The expression of ACS and $\mathrm{MCPT1}$ was found not to be changed in the diabetic heart (P.H.M. Willemsen and M. van Bilsen, unpublished observations) [13]. Thus, although the diabetic heart relies more on fatty acids, fatty acid metabolic gene expression is hardly altered and, therefore, seems to be of less importance in the metabolic adaptation of the heart during diabetes. In this respect, it is worth to note that a study, in which substrate oxidation was determined in hearts of chronic diabetic rats, demonstrated that palmitate oxidation was not altered compared to control hearts, whereas the oxidation of glucose markedly decreased [29], corroborating the findings at the level of gene expression. The mechanism responsible for cardiac metabolic remodelling during diabetes is largely unknown. Theoretically, fatty acids could play a role, since circulating fatty acid levels are elevated in patients and animals suffering from diabetes [28]. Moreover, tissue levels of fatty acids have been shown to be increased in hearts of diabetic rats $[9,36]$. However, the many metabolic and hormonal changes occurring in the diabetic body, e.g. alterations in glucose and insulin levels, make it difficult to examine whether fatty acids per se induce the metabolic remodelling. Nevertheless, fatty acids have been proposed to be involved in the pathogenesis of diabetic cardiomyopathy, a phenomenon many diabetic patients are confronted with $[28,41]$. Indeed, excess fatty acids are able to cause detrimental effects on electrophysiological, biochemical and mechanical characteristics of the heart [41]. These effects may also play a role in the pathogenesis of inherited cardiomyopathies caused by genetic defects involving the oxidation of long-chain fatty acids. In these disorders, fatty acids or their metabolites accumulate in 
cardiac tissue [23]. Whether fatty acids may also influence the development of cardiomyopathies at the level of gene expression is, however, unknown.

In hypertrophied and failing hearts, in which fatty acid oxidation is declined $[2,20]$, the alteration in cardiac metabolism can be considered as a prominent feature of the cardiac disease. The expression of several genes coding for proteins involved in fatty acid metabolism has been shown to be downregulated in hypertrophied and failing hearts $[12,43,44]$. Conversely, mRNA levels of the glucose transporter GLUT1 increased, though GLUT4 expression decreased [12,42]. The mechanism causing the metabolic remodelling in hypertrophied and failing hearts is basically unknown, but it has been suggested that metabolites could be responsible [55]. Interestingly, PPAR $\alpha$ content was shown to be reduced in hypertrophied hearts, whereas nuclear levels of the chicken ovalbumin upstream promoter transcription factor (COUP-TF), able to antagonise PPAR activity by interacting with the PPRE [33], increased [43]. In addition, it has been suggested that PPAR $\alpha$ activity is decreased in hypertrophied cardiomyocytes by phosphorylation via the extracellular signal-regulated kinase mitogen-activated protein kinase (ERK-MAPK) pathway [3]. These findings may provide an explanation for the decreased expression of fatty acid metabolic genes. In addition, there are indications that other transcription factors, such as Sp1 and Sp3, are involved in cardiac metabolic remodelling [43]. It is worth to note that the metabolic changes occurring in hypertrophied and failing hearts are likely to be part of the re-activation of the foetal gene expression program, including, for example, the re-expression of atrial natriuretic factor by ventricular myocytes [54,55], suggesting that a general mechanism is triggering the remodelling of the heart. The MAPK pathways are thought to play an important role herein [50].

Recently, PPARs have been suggested to be implicated in cardiac pathophysiology. The most striking example is that PPAR $\alpha$ deficient mice, in which the cardiac uptake and oxidation of fatty acids was found to be lower than in wild-type mice, display cardiac abnormalities, including contraction band necrosis and myocardial fibrosis, regarded as unclassified cardiomyopathy that increased with age [57]. In addition, it was demonstrated that activators of PPAR $\alpha$ and PPAR $\gamma$ are able to inhibit lipopolysaccharide (LPS)-induced expression of tumour necrosis factor $\alpha$ (TNF $\alpha$ ) in cultured neonatal cardiac myocytes [51]. The proinflammatory cytokine TNF $\alpha$ has been proposed to be implicated in the progression of heart failure [30]. Thus, hypothetically, fatty acids could attenuate progression of cardiac diseases by activation of PPARs, and, hence, exert a beneficial effect on cardiac functioning by modulating gene expression.

\section{Future perspectives}

The present finding that fatty acids are able to modulate cardiac metabolic gene expression is intriguing and raises several questions and ideas that should be explored. First of all, the exact signalling pathways by which fatty acids modulate cardiac gene expression are waiting to be unravelled. PPAR $\alpha$ is probably one of the most important transcription factors mediating the effects of fatty acids on cardiac 
metabolic gene expression, but other pathways cannot be excluded yet. The availability of many molecular biological tools, including transgenic animals, should make it possible to identify alternative routes of fatty acid-mediated gene expression. Second, the question remains whether fatty acids are also able to regulate the expression of genes encoding proteins not directly involved in cardiac metabolism. If fatty acids are able to alter the expression of genes like, for example, angiotensinogen, as shown for preadipocytes [45], this will raise a new perspective on cardiac pathogenesis.

A third point of interest is the possibility to manipulate cardiac functioning by modulating the dietary intake of fatty acids. It is conceivable that an increased intake of fatty acids will enhance cardiac fatty acid oxidation, but could it have consequences on cardiac performance as well? It has been demonstrated that in perfused rat hearts functional recovery after a period of ischaemia was improved when the animals had been fasted [34]. Whether this improved response can be mimicked solely by increasing fatty acid oxidation is uncertain, but it indicates that restriction from food may be beneficial in reducing myocardial injury following cardiac surgery. This thesis focussed on palmitic and oleic acid as regulators of cardiac gene expression. It is unknown if distinct types of fatty acids, like n-3 and n-6 polyunsaturated fatty acids, may exert different effects. Beneficial effects of $n-3$ polyunsaturated fatty acids, major components of fish oil, have been described on coronary heart disease, arrhythmias, and diabetes $[11,49]$. It remains to be established whether these effects are obtained via modulation of gene expression. For instance, the anti-arrhythmic effects appear to be rather acute, since irregular and asynchronous contractions in cultured cardiac myocytes were terminated within minutes after addition of an n-3 polyunsaturated fatty acid [21], and are therefore not supposed to involve transcriptional regulation. It would be of interest to examine the effects of long-term exposure of these specific fatty acids on, for instance, cultured cardiomyocytes and to compare them with the effects found on gene expression by palmitic and oleic acid.

In conclusion, the ability of fatty acids to alter gene expression in heart muscle cells opens new perspectives in the field of cardiac research. The speculation that patients may eventually be treated by adjusting their diet and/or by drugs that specifically target metabolic gene expression in order to restore cardiac function is very exciting, and should therefore be elaborated.

\section{References}

1. Adams JW, Migita DS, Yu MK, Young R, Hellickson MS, Castro-Vargas FE, Domingo JD, Lee PH, Bui JS, and Henderson SA (1996). Prostaglandin F2 $\alpha$ stimulates hypertrophic growth of cultured neonatal rat ventricular myocytes. I Biol Chem 271, 1179-1186

2. Allard MF, Schönekess BO, Henning SL, English DR, and Lopaschuk GD (1994). Contribution of oxidative metabolism and glycolysis to ATP production in hypertrophied hearts. Am ) Physiol 267, H742-H750 
3. Barger PM, Brandt JM, Leone TC, Weinheimer Cl, and Kelly DP (2000). Deactivation of peroxisome proliferator-activated receptor- $\alpha$ during cardiac hypertrophic growth. / Clin Invest $105,1723-1730$

4. Bastie C, Holst D, Gaillard D, Jehl-Pietri C, and Grimaldi PA (1999). Expression of peroxisome proliferator-activated receptor PPARS promotes induction of PPAR $\gamma$ and adipocyte differentiation in 3T3C2 fibroblasts. / Biol Chem 274, 21920-21925

5. Bastie C, Luquet S, Holst D, Jehl-Pietri C, and Grimaldi PA (2000). Alterations of peroxisome proliferator-activated receptor $\delta$ activity affect fatty acid-controlled adipose differentiation. I Biol Chem 275, 38768-38773

6. Brandt JM, Djouadi F, and Kelly DP (1998). Fatty acids activate transcription of the muscle carnitine palmitoyltransferase 1 gene in cardiac myocytes via the peroxisome proliferatoractivated receptor $\alpha$. / Biol Chem 273, 23786-23792

7. Camps M, Castello A, Munoz P, Monfar M, Testar X, Palacin M, and Zorzano A (1992). Effect of diabetes and fasting on GLUT-4 (muscle/fat) glucose-transporter expression in insulinsensitive tissues. Heterogeneous response in heart, red and white muscle. Biochem / 282, 765-772

8. Chatelain F, Kohl C, Esser V, McGarry JD, Girard I, and Pegorier J-P (1996). Cyclic AMP and fatty acids increase carnitine palmitoyltransferase I gene transcription in cultured fetal rat hepatocytes. Eur / Biochem 235, 789-798

9. Chattopadhyay J, Thompson EW, and Schmid HH (1990). Elevated levels of nonesterified fatty acids in the myocardium of alloxan diabetic rats. Lipids 25, 307-310.

10. Cook WS, Yeldandi AV, Rao MS, Hashimoto T, and Reddy JK (2000). Less extrahepatic induction of fatty acid $\beta$-oxidation enzymes by PPAR $\alpha$. Biochem Biophys Res Commun 278, 250-257

11. Das UN (2000). Beneficial effect(s) of n-3 fatty acids in cardiovascular diseases: but, why and how? Prostaglandins Leukot Essent Fatty Acids 63, 351-362

12. Depre C, Shipley GL, Chen W, Han Q, Doenst T, Moore ML, Stepkowski S, Davies PJA, and Taegtmeyer $H$ (1998). Unloaded heart in vivo replicates fetal gene expression of cardiac hypertrophy. Nature Med 4, 1269-1275

13. Depre C, Young ME, Ying J, Ahuja HS, Han Q, Garza N, Davies PJ, and Taegtmeyer H (2000), Streptozotocin-induced changes in cardiac gene expression in the absence of severe contractile dysfunction. / Mol Cell Cardiol 32, 985-996

14. Desvergne B and Wahli W (1999). Peroxisome proliferator-activated receptors: nuclear control of metabolism. Endocr Rev 20, 649-688

15. Foufelle F, Girard J, and Ferré P (1998). Glucose regulation of gene expression. Curr Opin Clin Nutr Metab Care 1, 323-328

16. Girard J, Ferré P, Pégorier J-P, and Duée P.H (1992). Adaptations of glucose and fatty acid metabolism during perinatal period and suckling-weaning transition. Physiol Rev 72, 507-562

17. Grimaldi PA, Knobel SM, Whitesell RR, and Abumrad NA (1992). Induction of aP2 gene expression by nonmetabolized long-chain fatty acids. Proc Natl Acad Sci USA 89, 1093010934

18. Hertz R, Magenheim J, Berman I, and Bar-Tana J (1998). Fatty acyl-CoA thioesters are ligands of hepatic nuclear factor-4 $\alpha$. Nature $392,512-516$

19. Inoue A, Yamamoto $N$, Morisawa $Y$, Uchimoto T, Yukioka $M$, and Morisawa $S$ (1989). Unesterfied long-chain fatty acids inhibit thyroid hormone binding to the nuclear receptor. Solubilized receptor and the receptor in cultured cells. Eur / Biochem 183, 565-572

20. Kagaya $Y$, Kanno $Y$, Takeyama D, Ishide N, Maruyama $Y$, Takahashi T, Ido T, and Takishima $T$ (1990). Effects of long-term pressure overload on regional myocardial glucose and free fatty acid uptake in rats. A quantitative autoradiographic study. Circulation 81, 1353-1361

21. Kang J and Leaf A (2000). Prevention of fatal cardiac arrhythmias by polyunsaturated fatty acids. Am / Clin Nutr 71, 2025-2075 
22. Kelly DP, Gordon JI, Alpers R, and Strauss AW (1989). The tissue-specific expression and developmental regulation of two nuclear genes encoding rat mitochondrial proteins. Medium chain acyl-CoA dehydrogenase and mitochondrial malate dehydrogenase. I Biol Chem 264, 18921-18925

23. Kelly DP and Strauss AW (1994). Inherited cardiomyopathies. New Eng/ / Med 330, 913-919

24. Khan WA, Blobe GC, and Hannun YA (1995). Arachidonic acid and free fatty acids as second messengers and the role of protein kinase $C$. Cell Signal 7, 171-184

25. Lai J, Jin H, Yang R, Winer J, Li W, Yen R, King KL, Zeigler F, Ko A, Cheng J, Bunting S, and Paoni NF (1996). Prostaglandin F2 $\alpha$ induces cardiac myocyte hypertrophy in vitro and cardiac growth in vivo. Am J Physiol 271, H2197-2208.

26. Leone TC, Weinheimer CJ, and Kelly DP (1999). A critical role for the peroxisome proliferatoractivated receptor $\alpha$ (PPAR $\alpha$ ) in the cellular fasting response: The PPAR $\alpha$-null mouse as a model of fatty acid oxidation disorders. Proc Natl Acad Sci USA 96, 7473-7478

27. Li Q, Yamamoto N, Morisawa S, and Inoue A (1993). Fatty acyl-CoA binding activity of the nuclear thyroid hormone receptor. I Cell Biochem 51, 458-464.

28. Lopaschuk GD (1992). Fatty acid metabolism in the heart following diabetes. In The heart in diabetes. Chatham JC, Forder JR, and MCNeill JH, Eds. Kluwer Academic Publishers, Boston, 215-251

29. Lopaschuk GD and Spafford MA (1991). Glucose and palmitate oxidation during reperfusion of ischemic hearts from diabetic rats. In The diabetic heart. Nagano $M$, and Dhalla NS, Eds. Raven Press, Ltd., New York, 451-464

30. Mann DL (1996). The effect of tumor necrosis factor- $\alpha$ on cardiac structure and function: a tale of two cytokines. / Card Fail 2, S165-S172

31. Martin G, Schoonjans K, Lefebvre A-M, Staels B, and Auwerx J (1997). Coordinate regulation of the expression of the fatty acid transport protein and acyl-CoA synthetase genes by PPAR $\alpha$ and PPARy activators. I Biol Chem 272, 28210-28217

32. Meunier-Durmort $C$, Poirier $H$, Niot $I$, Forest $C$, and Besnard $P$ (1996). Up-regulation of the expression of the gene for liver fatty acid-binding protein by long-chain fatty acids. Biochem I $319,483-487$

33. Miyata KS, Zhang B, Marcus SL, Capone JP, and Rachubinski RA (1993). Chicken ovalbumin upstream promoter transcription factor (COUP-TF) binds to a peroxisome proliferatorresponsive element and antagonizes peroxisome proliferator-mediated sigaling. I Biol Chem 268, 19169-19172

34. Montessuit C, Papageorgiou I, Tardy I, and Lerch R (1996). Effect of nutritional state on substrate metabolism and contractile function in postischemic rat myocardium. Am / Physiol $271, \mathrm{H} 2060-\mathrm{H} 2070$

35. Navankasattusas $S$, Sawadogo $M$, van Bilsen $M$, Dang CV, and Chien KR (1994). The basic helix-loop-helix protein upstream stimulating factor regulates the cardiac ventricular myosin light-chain 2 gene via independent cis regulatory elements. Mol Cell Biol 14, 7331-7339.

36. Nawrocki A, Gorska M, Wojcik B, and Buslowska A (1999). Effect of streptozotocin diabetes on fatty acid content and composition of the heart lipids in the rat. Rocz Akad Med Bialymst 44, $170-179$

37. Negishi $M$, Sugimoto $Y$, and Ichikawa $A$ (1995). Molecular mechanisms of diverse actions of prostanoid receptors. Biochim Biophys Acta 1259, 109-119.

38. Opie LH, Evans JR, and Shipp JC (1963). Effect of fasting on glucose and palmitate metabolism of perfused rat heart. Am / Physiol 205, 1203-1208

39. Ouali F, Djouadi F, Merlet-Bénichou C, Riveau B, and Bastin J (2000). Regulation of fatty acid transport protein and mitochondrial and peroxisomal $\beta$-oxidation gene expression by fatty acids in developing rats. Pediatr Res 48, 691-696

40. Peters JM, Lee SS, Li W, Ward JM, Gavrilova O, Everett C, Reitman ML, Hudson LD, and Gonzalez FJ (2000). Growth, adipose, brain, and skin alterations resulting from targeted 
disruption of the mouse peroxisome proliferator-activated receptor $\beta(\delta)$. Mol Cell Biol 20, 5119-5128

41. Rodrigues B and MCNeill JH (1992). The diabetic heart: metabolic causes for the development of a cardiomyopathy. Cardiovasc Res 26, 913-922

42. Rosenblatt-Velin N, Papageorgiou I, Terrand J, and Lerch R (1999). Progression from hypertrophy to heart failure is associated with upregulation of GLUT-1. Abstract. / Mol Cell Cardiol 31, A77

43. Sack MN, Disch DL, Rockman HA, and Kelly DP (1997). A role for Sp and nuclear receptor transcription factors in a cardiac hypertrophic growth program. Proc Natl Acad Sci USA 94, 6438-6443

44. Sack MN, Rader TA, Park S, Bastin J, MCCune SA, and Kelly DP (1996). Fatty acid oxidation enzyme gene expression is downregulated in the failing heart. Circulation 94, 2837-2842

45. Safonova I, Aubert J, Negrel R, and Ailhaud $G$ (1997). Regulation by fatty acids of angiotensinogen gene expression in preadipose cells. Biochem / 322, 235-239

46. Schoonjans K, Staels B, and Auwerx J (1996). The peroxisome proliferator activated receptors (PPARs) and their effects on lipid metabolism and adipocyte differentiation. Biochim Biophys Acta 1302, 93-109

47. Schoonjans K, Staels B, Grimaldi P, and Auwerx J (1993). Acyl-CoA synthetase mRNA expression is controlled by fibric-acid derivatives, feeding and liver proliferation. Eur I Biochem 216, 615-622

48. Shih HM and Towle HC (1992). Definition of the carbohydrate response element of the rat S14 gene. Evidence for a common factor required for carbohydrate regulation of hepatic genes. I Biol Chem 267, 13222-13228

49. Simopoulos AP (1999). Essential fatty acids in health and chronic disease. Am / Clin Nutr 70, 560S-569S

50. Sugden PH and Clerk A (1998). Cellular mechanisms of cardiac hypertrophy. / Mol Med 76, 725-746.

51. Takano H, Nagai T, Asakawa M, Toyozaki T, Oka T, Komuro I, Saito T, and Masuda Y (2000), Peroxisome proliferator-activated receptor activators inhibit lipopolysaccharide-induced tumor necrosis factor- $\alpha$ expression in neonatal rat cardiac myocytes. Circ Res 87, 596-602

52. Thompson KS and Towle HC (1991). Localization of the carbohydrate response element of the rat L-type pyruvate kinase gene. J Biol Chem 266, 8679-8682.

53. Van Bilsen $M$ (1997). Signal transduction revisited: recent developments in angiotensin II signaling in the cardiovascular system. Cardiovasc Res 36, 310-322

54. Van Bilsen $M$ and Chien KR (1993). Growth and hypertrophy of the heart: towards an understanding of cardiac specific and inducible gene expression. Cardiovasc Res 27, 11401149

55. Van Bilsen $M$, van der Vusse GJ, and Reneman RS (1998). Transcriptional regulation of metabolic processes: implications for cardiac metabolism. Eur / Physiol 437, 2-14

56. Van Nieuwenhoven FA, Willemsen PHM, van der Vusse G], and Glatz JFC (1999). Coexpression in rat heart and skeletal muscle of four genes coding for proteins implicated in long-chain fatty acid uptake. Int / Biochem Cell Biol 31, 489-498

57. Watanabe K, Fuji H, Takahashi T, Kodama M, Aizawa $Y$, Ohta $Y$, Ono T, Hasegawa G, Naito M, Nakajima T, Kamijo Y, Gonzalez FJ, and Aoyama T (2000). Constitutive regulation of cardiac fatty acid metabolism through peroxisome proliferator-activated receptor $\alpha$ associated with age-dependent cardiac toxicity. I Biol Chem 275, 22293-222.99

58. Wiersinga WM, Chopra IJ, and Teco GNC (1988). Inhibition of nuclear Ta binding by fatty acids. Metabolism 37, 996-1002

59. Xiao $Q$ and Ojamaa $K$ (1998). Regulation of cardiac $\alpha$-myosin heavy chain gene transcription by a contractile-responsive E-box binding protein. / Mol Cell Cardiol 30, 87-95. 


\section{Abbreviations}

ACS acyl-CoA synthetase

ANF atrial natriuretic factor

BAT brown adipose tissue

BSA bovine serum albumin

C16:0 palmitic acid

C18:1 oleic acid

CoA coenzyme A

CPT carnitine palmitoyl transferase

CS citrate synthase

FA fatty acids

FABP fatty acid-binding protein

$\mathrm{FADH}_{2}$ flavine adenine dinucleotide

FAT fatty acid translocase/CD36

FATP fatty acid transport protein

GAPDH glyceraldehyde-3-phosphate dehydrogenase

GLUT glucose transporter

HAD 3-hydroxyacyl-CoA dehydrogenase

H-FABP heart-type fatty acid-binding protein

HK hexokinase

LCAD long-chain acyl-CoA dehydrogenase

$\mathrm{LDH} \quad$ lactate dehydrogenase

LPL lipoprotein lipase

MAP mitogen-activated protein

MCAD medium-chain acyl-CoA dehydrogenase

mCPT muscle-type carnitine palmitoyl transferase

$\mathrm{NADH}$ nicotinamide adenine dinucleotide

PCR polymerase chain reaction

$\mathrm{PDH} \quad$ pyruvate dehydrogenase

PE phenylephrine

PFK phosphofructo-1-kinase

$P_{i} \quad$ inorganic phosphate

PPAR peroxisome proliferator-activated receptor

PPRE peroxisome proliferator-responsive element

RXR retinoid-X-receptor

SERCA sarcoplasmic reticulum $\mathrm{Ca}^{2+}$-ATPase

T3 triiodothyronine

TR thyroid hormone receptor 
$120 \mid$ Abbreviations

TZD thiazolidinedione

UCP uncoupling protein

WAT white adipose tissue 


\section{Summary}

In order to maintain its function the heart is able to use a variety of energy-providing substrates, including fatty acids, glucose and lactate. For the healthy adult heart fatty acids are the chief -source of energy. Under different physiological and pathophysiological conditions a shift in the utilisation of substrates occurs. During perinatal development, and in the adult during fasting and diabetes, the contribution of fatty acids to total cardiac energy production increases. In contrast, the utilisation of fatty acids by the heart decreases during cardiac hypertrophy and cardiac failure. A general introduction into myocardial substrate transport and metabolism is given in chapter 1. The activity of substrate-handling proteins can be regulated at short-term and long-term basis. Regulation at the long term, i.e. hours to days, includes the alterations of the rate of gene transcription and translation. Recently, it became apparent that fatty acids themselves are able to modulate the expression of certain metabolic genes in a number of cell types. In this thesis the effects of fatty acids on the expression of genes coding for proteins involved in substrate transport and metabolism in cardiac muscle cells is described.

Although the exact mechanism that mediates the fatty acid-induced changes in cardiac gene expression is incompletely understood, a major role has been proposed for the peroxisomal proliferator-activated receptors (PPARs). The potential role of these transcription factors in the regulation of cardiac gene expression is reviewed in chapter 2. Fatty acids are able to bind to and, consequently, activate PPARs. In addition, it has already been demonstrated that PPARs play a major role in the regulation of genes coding for proteins involved in whole-body and cellular lipid metabolism. Thus, PPARs may indeed mediate the fatty acid-induced changes in cardiac gene expression.

To determine whether fatty acids are able to modulate gene expression in heart muscle cells, primary cultures of neonatal rat cardiomyocytes were exposed to a combination of palmitic and oleic acid for 48 hours (chapter 3 ). This not only resulted in an increased intracellular accumulation of triacylglycerols but also in marked changes in metabolic gene expression. Whereas genes encoding proteins involved in fatty acid transport and metabolism were consistently upregulated, genes coding for proteins involved in glucose transport and metabolism were downregulated. The changes in gene expression were associated with a significant increase in the capacity of the neonatal cardiomyocytes to oxidise fatty acids. A first link with PPARs was also made. Three PPAR isoforms exist, PPAR $\alpha, P P A R \beta / \delta$ and PPAR $\gamma$. Here it is shown that a specific ligand for PPAR $\alpha$, but not for PPAR $\gamma$, is able to mimic the fatty acid-induced upregulation of genes coding for proteins involved in fatty acid metabolism.

The role of PPARs in cardiac muscle cells was examined in more detail in the study described in chapter 4 . In this study not only neonatal rat cardiomyocytes were used but also embryonic rat heart-derived $\mathrm{H} 9 \mathrm{c} 2$ cells. The latter cells are able to differentiate from myoblasts into multinucleated myotubes and for this reason, among 
others, they not only resemble cardiac myocytes but also skeletal muscle cells. Compared to neonatal cardiomyocytes, $\mathrm{H} 9 \mathrm{c} 2$ cells respond only modestly to fatty acids. Interestingly, determination of the PPAR isoform distribution at the mRNA level revealed that PPAR $\alpha$ could only be detected in neonatal cardiomyocytes and not in $\mathrm{H} 9 \mathrm{C} 2$ cells. In contrast, PPAR $\beta / \delta$ was present in both cell types and PPAR $\gamma$ mRNA was neither in neonatal cardiomyocytes detectable nor in $\mathrm{H} 9 \mathrm{c} 2$ cells. The differences in PPAR isoform distribution may explain the modest response of $\mathrm{H} 9 \mathrm{C} 2$ cells to fatty acids. The effects of synthetic PPAR isoform specific ligands corroborated the PPAR distribution. Thus, a PPAR $\gamma$ agonist failed to modulate metabolic gene expression in neonatal cardiac myocytes and $\mathrm{H} 9 \mathrm{c} 2$ cells, and a PPAR $\alpha$ agonist only increased the expression of fatty acid metabolic genes in neonatal cardiomyocytes. In $\mathrm{H} 9 \mathrm{c} 2$ cells a PPAR $\beta / \delta$ agonist clearly mimicked the fatty acid-induced upregulation of genes. In contrast, the effects of the PPAR $\beta / \delta$-specific ligand were only modest in neonatal cardiomyocytes when compared to the PPAR $\alpha$ ligand-induced changes. These findings point to redundant roles for PPAR $\alpha$ and PPAR $\beta / \delta$ in cardiac metabolic gene expression.

So far, the effects of fatty acids on the expression of genes coding for proteins involved in glucose and fatty acid uptake and metabolic conversion were studied. The uncoupling protein UCP-2, able to uncouple oxidative phosphorylation by moving protons from the mitochondrial intermembrane space towards the mitochondrial matrix, has also been suggested to play a role in fatty acid metabolism. In the study presented in chapter 5 the effects of fatty acids on the cardiac expression of this protein at the mRNA level have been examined. UCP-2 expression was found to be inducible by fatty acids in vitro in neonatal rat cardiomyocytes and $\mathrm{H} 9 \mathrm{c} 2$ cells. In vivo, cardiac expression of UCP-2 was increased in newborn rats in which fatty acid levels in the blood are increased following suckling. In contrast, UCP-2 mRNA levels did not alter in the adult rat heart under conditions in which cardiac fatty acid metabolism and/or circulating fatty acid levels are changed (fasting, diabetes, cardiac hypertrophy). At present no explanation can be given for this discrepancy. However, it is conceivable that in the adult heart either fatty acids already maximally induce UCP-2 expression or the sensitivity towards fatty acids has been lost.

The presented studies demonstrate that in vitro fatty acids are able to modulate gene expression in cardiac muscle cells, resulting in an altered fatty acid metabolism. In chapter 6 fasting is used as an in vivo model to investigate the effects of fatty acids on the in situ rat heart. During fasting, fatty acid levels in the blood are elevated and this is accompanied with an increased utilisation of fatty acids by the heart. It was found that the expression of the majority of cardiac fatty acid metabolic genes and also of the gene coding for the uncoupling protein UCP-3 increased after 46 hours of fasting, whereas the expression of a set of genes coding for glucose-handling proteins declined. By treating the rats with the anti-lipolytic agent nicotinic acid for the final 8 hours of the fasting period, the circulating fatty acid levels were reduced. This did, however, not result in a reversion of the mRNA levels investigated, with exception of UCP3 mRNA. Although it could not be established that fatty acids per se are responsible for the changes in cardiac metabolic gene expression as induced during 
fasting, the study demonstrates that the metabolic plasticity of the heart, in vivo, may have its origin in changes at the level of gene expression.

In the final chapter of this thesis, chapter 7, the major findings are discussed and suggestions for future research are given. The role of PPARs in fatty acid-mediated cardiac gene expression should be elaborated as well as other potential molecular mechanisms involved. Furthermore, it is of interest to examine whether genes other than those coding for metabolic proteins are regulated by fatty acids. Of special interest is the role that fatty acid-mediated gene expression may have in cardiac pathophysiology, an issue with pertinent clinical relevance. 
124 


\section{Samenvatting}

Om zijn functie te kunnen waarborgen, is het hart in staat om gebruik te maken van een verscheidenheid aan energie leverende substraten, zoals vetzuren, glucose en melkzuur. Voor het gezonde, volwassen hart vormen vetzuren de belangrijkste energiebron. Tijdens verschillende fysiologische en pathofysiologische omstandigheden kan er echter een verandering optreden in het gebruik van de diverse substraten. Tijdens de perinatale ontwikkeling, en, in de adult, tijdens vasten en diabetes neemt de bijdrage van vetzuren aan de totale cardiale energieproductie toe. Daarentegen neemt het vetzuurverbruik door het hart af tijdens cardiale hypertrofie en hartfalen. Een algemene introductie in het transport en metabolisme van substraten in de hartspiercel is gegeven in hoofdstuk 1. De activiteit van de vele eiwitten die hierbij betrokken zijn kan zowel op de korte als op de lange termijn worden gereguleerd. Regulatie op de lange termijn (uren tot dagen) houdt onder ander in dat er veranderingen plaats kunnen vinden in de snelheid van gentranscriptie en translatie. Recent is duidelijk geworden dat vetzuren zelf in staat zijn om de transcriptie van bepaalde metabole genen in verschillende celtypen te moduleren. In dit proefschrift zijn de effecten van vetzuren op de expressie van genen die coderen voor eiwitten betrokken bij het substraattransport en -metabolisme in hartspiercellen beschreven.

Het exacte mechanisme dat de door vetzuren geïnduceerde veranderingen in cardiale genexpressie medieert is nog niet helemaal begrepen. Wel is er gesuggereerd dat de peroxisoom proliferator geactiveerde receptoren (PPARs) hierbij een belangrijke rol spelen. Vetzuren zijn in staat om een interactie aan te gaan met deze transcriptiefactoren en ze daardoor te activeren. Daarnaast is aangetoond dat PPARs betrokken zijn bij de regulatie van genen die coderen voor eiwitten die nodig zijn voor het systemische en intracellulaire vetmetabolisme. Het lijkt er dus op dat PPARs inderdaad de door vetzuren geïnduceerde veranderingen in de cardiale genexpressie kunnen mediëren. De mogelijke functie van deze transcriptiefactoren in het hart is uitgebreid besproken in hoofdstuk 2.

$\mathrm{Om}$ te testen of vetzuren in staat zijn de genexpressie in hartspiercellen te moduleren, zijn primaire kweken van neonatale rattenhartspiercellen 48 uur lang blootgesteld aan een combinatie van palmitine- en oliezuur (hoofdstuk 3). Deze blootstelling resulteerde niet alleen in een accumulatie van triglyceriden, maar ook in een duidelijke veranderingen in de mRNA gehaltes van metabole eiwitten. De expressie van genen die coderen voor eiwitten betrokken bij het transport en metabolisme van vetzuren nam consequent toe. Daarentegen nam de expressie van genen coderende voor eiwitten betrokken bij het transport en metabolisme van glucose af. Deze veranderingen in genexpressie bleken geassocieerd te zijn met een significante toename in de capaciteit van de neonatale cardiomyocyten om vetzuren te oxideren. In de in hoofdstuk 3 gepresenteerde studie werd ook een eerste verband gelegd met PPARs. Er bestaan drie PPAR isovormen: PPAR $\alpha$, PPAR $\beta / \delta$ en PPAR $\gamma$. Hier is aangetoond dat een specifieke ligand voor PPAR $\alpha$, maar niet voor PPAR $\gamma$, in staat is 
om de door vetzuren geïnduceerde toename van de expressie van genen die coderen voor eiwitten betrokken bij het vetzuurmetabolisme na te bootsen.

De rol van PPARs in hartspiercellen is vervolgens nader onderzocht (hoofdstuk 4). Hiertoe zijn niet alleen neonatale rattencardiomyocyten gebruikt, maar ook de $\mathrm{H} 9 \mathrm{c} 2$ cellijn, die afkomstig zijn van een embryonaal rattenhart. H9c2 cellen zijn in staat om te differentiëren van myoblasten naar meerkernige, zogenaamde myotubes. Onder meer om deze reden vertonen ze niet alleen overeenkomsten met hartspiercellen, maar ook met skeletspiercellen. Vergeleken met neonatale cardiomyocyten, reageren de $\mathrm{H} 9 \mathrm{c} 2$ ceilen slechts minimaal op vetzuren. Interessant is, dat uit de bepaling van de PPAR isovorm distributie op mRNA niveau bleek, dat PPAR $\alpha$ alleen in de neonatale cardiomyocyten aanwezig was en niet in $\mathrm{H} 9 \mathrm{c} 2$ cellen. Dit in tegenstelling tot PPAR $\beta / \delta$, die in beide celtypen gedetecteerd kon worden, en PPAR $\gamma$, die helemaal niet detecteerbaar was in de neonatale hartspiercellen of $\mathrm{H} 9 \mathrm{c} 2$ cellen. De verschillen in distributie van de PPAR isovormen zouden de minimale respons van de H9c2 cellen op vetzuren kunnen verklaren. De effecten van synthetische liganden, die specifiek binden aan één PPAR isovorm, bevestigen de PPAR distributie nog eens. Een PPAR $\gamma$ agonist bleek aldus niet in staat te zijn om de metabole genexpressie in neonatale hartspiercellen en in $\mathrm{H} 9 \mathrm{c} 2$ cellen te veranderen, terwijl een PPAR $\alpha$ agonist alleen in neonatale cardiomyocyten de expressie van vetzuur-metabole genen verhoogde. In $\mathrm{H} 9 \mathrm{C} 2$ cellen bootste een PPAR $\beta / \delta$ agonist de door vetzuren veroorzaakte toename in genexpressie duidelijk na. Daarentegen had de PPAR $\beta / \delta$ specifieke ligand, vergeleken met de PPAR $\alpha$-specifieke ligand, slechts een gering effect in neonatale cardiomyocyten. Deze bevindingen wijzen erop dat PPAR $\alpha$ en PPAR $\beta / \delta$ elkaars rol in de cardiale metabole genexpressie kunnen opvangen.

Tot zo ver zijn de effecten van vetzuren onderzocht op genen die coderen voor eiwitten die iets te maken hebben met de opname en het metabolisme van glucose en vetzuren. Het ontkoppelingseiwit ("uncoupling protein") UCP-2 is in staat om ATP synthase te ontkoppelen van de ademhalingsketen, door protonen uit de intermembraanruimte door te sluizen naar de mitochondriële matrix. $\mathrm{Er}$ is gesuggereerd dat de tot nu toe onbekende functie van UCP-2 op enigerlei wijze te maken heeft met het vetzuurmetabolisme. In de studie die beschreven is in hoofdstuk 5 , zijn de effecten van vetzuren op de cardiale expressie van dit eiwit op mRNA niveau onderzocht. De UCP-2 expressie bleek door vetzuren induceerbaar te zijn in gekweekte neonatale rattencardiomyocyten en in $\mathrm{H} 9 \mathrm{c} 2$ cellen. Ook bleek de cardiale expressie van UCP-2 in vivo toe te nemen in pasgeboren ratten, waarbij direct na het zogen de vetzuurspiegels in het bloed stijgen. Het gehalte aan UCP-2 mRNA veranderde echter niet in het adulte rattenhart onder condities waarbij het cardiale vetzuurmetabolisme en/of de circulerende vetzuurspiegels veranderd zijn (vasten, diabetes, cardiale hypertrofie). Tot nu toe is nog geen verklaring voor gevonden voor deze verschillen. Wel is het denkbaar, dat normale bloedconcentraties van vetzuren de expressie van UCP-2 al maximaal induceren in het adulte hart of dat het adulte hart niet meer gevoelig is voor vetzuren.

Bovenstaande studies tonen aan dat vetzuren in vitro in staat zijn om de expressie van genen die coderen voor eiwitten, waarvan bekend is dat ze betrokken zijn bij 
vetzuurtransport of -metabolisme, te moduleren in hartspiercellen. Om de effecten van vetzuren op het intacte rattenhart te bestuderen, werden ratten 46 uur lang gevast (hoofdstuk 6). Tijdens zo'n periode van vasten zijn de vetzuurspiegels in het bloed verhoogd en neemt het verbruik van vetzuren door het hart toe. De expressie van de meerderheid van de cardiale vetzuur-metabole genen en ook van het gen coderend voor het ontkoppelingseiwit UCP-3 bleek na het vasten te zijn toegenomen, terwijl de expressie van de onderzochte glucose-metabole genen afnam. Door de ratten gedurende de laatste acht uur van de vastenperiode te behandelen met het antilipolytische agens nicotinezuur, daalden de vetzuurspiegels weer. Dit zorgde er echter niet voor dat de veranderde mRNA gehaltes terugkeerden naar hun normaalwaarden, met uitzondering van het UCP3 mRNA. Hoewel niet kon worden vastgesteld dat vetzuren zelf verantwoordelijk zijn voor de veranderingen in de expressie van cardiale genen tijdens vasten, toont deze studie wel aan, dat de metabole plasticiteit van het in vivo hart zijn oorsprong al kan hebben op het niveau van genexpressie.

In het laatste hoofdstuk van dit proefschrift, hoofdstuk 7, zijn de belangrijkste bevindingen bediscussieerd en zijn suggesties gegeven voor toekomstig onderzoek. De rol van PPARs in de vetzuur-gemedieerde genexpressie in het hart zou nader onderzocht moeten worden evenals mogelijke andere mechanismen die hierbij betrokken kunnen zijn. Verder is het interessant om te onderzoeken welke genen, die niet coderen voor eiwitten die betrokken zijn bij het metabolisme, gereguleerd kunnen worden door vetzuren. Van bijzonder belang is de rol die vetzuurgemedieerde genexpressie zou kunnen hebben in de cardiale pathofysiologie, een onderwerp met een klinische betekenis. 
128 


\section{Samenvatting voor niet-vakgenoten}

Het hart kan gezien worden als een pomp. Doordat het hart ritmisch samentrekt, zorgt het ervoor dat alle organen in het lichaam van bloed worden voorzien. Om deze activiteit te kunnen waarborgen is het hart afhankelijk van een continue toevoer van zuurstof en voedingsstoffen. Deze stoffen worden aangeleverd via de kransslagaderen. Het hart kan verschillende soorten voedingsstoffen, ook wel substraten genoemd, gebruiken om er energie uit te winnen. Onder normale omstandigheden gebruikt het hart voornamelijk glucose en vetzuren als substraat. De bijdrage van vetzuren aan de energieproductie door het hart is zelfs bijna 70\%. Dit aandeel kan echter onder bepaalde omstandigheden veranderen. Zo is het hart van een ongeboren mens of dier voor het grootste deel van glucose afhankelijk en neemt het vetzuurverbruik na de geboorte toe. Tijdens een periode van vasten en bij diabetici neemt het aandeel van vetzuren in de energieproductie door het hart nog verder toe tot ruim boven de $70 \%$. In het geval van een vergrote hartspier (cardiale hypertrofie) en van hartfalen neemt het gebruik van vetzuren daarentegen af en dat van glucose toe.

Om energie te kunnen winnen uit de diverse substraten, bezitten de spiercellen in het hart een scala aan eiwitten. Deze eiwitten zijn nodig om substraten te transporteren (transporteiwitten) of om te zetten (metabole eiwitten ofwel enzymen). In de figuur op de volgende pagina staat de route die vetzuren in de cel volgen schematisch weergegeven samen met de belangrijkste eiwitten die erbij betrokken zijn. Vetzuren bestaan uit een waterafstotende keten van koolstofatomen met aan het eind een waterminnende kop. Ze kunnen de hartspiercel passief binnenkomen of met behulp van een transporteiwit, zoals het vetzuur translocase (FAT), dat zich in het membraan van de hartspiercel bevindt. In de cel vindt het transport van vetzuren plaats door het hart-type vetzuurbindende eiwit (H-FABP). Om te kunnen worden omgezet, moet een vetzuur eerst worden geactiveerd. Dit gebeurt door het enzym acyl-CoA synthetase (ACS), dat de kop van het vetzuur bindt aan co-enzym A (CoA). $\mathrm{Na}$ activatie kan het vetzuur verschillende kanten opgaan. Zo kan het in het vetdepot van de cel worden ingebouwd of in het membraan van de cel terechtkomen. Voor de productie van energie wordt het geactiveerde vetzuur echter stapsgewijs afgebroken. Dit gebeurt in de mitochondria, de energiefabriekjes van de cel. Geactiveerde vetzuren kunnen de mitochondria binnenkomen via een ingenieus shuttle mechanisme, waar het spier-type carnitine palmitoyl transferase 1 (mCPT1) bij betrokken is. In het mitochondrium wordt het geactiveerde vetzuur ingekort in een proces dat $\beta$-oxidatie heet. De eerste stap hiervan wordt verzorgd door het enzym langketenig acyl-CoA dehydrogenase (LCAD). Aan het eind van de $\beta$-oxidatie ontstaat acetyl-CoA (een verbinding tussen azijnzuur en $\mathrm{CoA}$ ), dat de citroenzuurcyclus binnengaat. In deze cyclus worden de waterstofatomen van het azijnzuur verwijderd. Deze waterstofatomen worden via de ademhalingsketen aan zuurstof gekoppeld, waarbij water als eindproduct ontstaat. De energie die hierbij vrijkomt, wordt door 


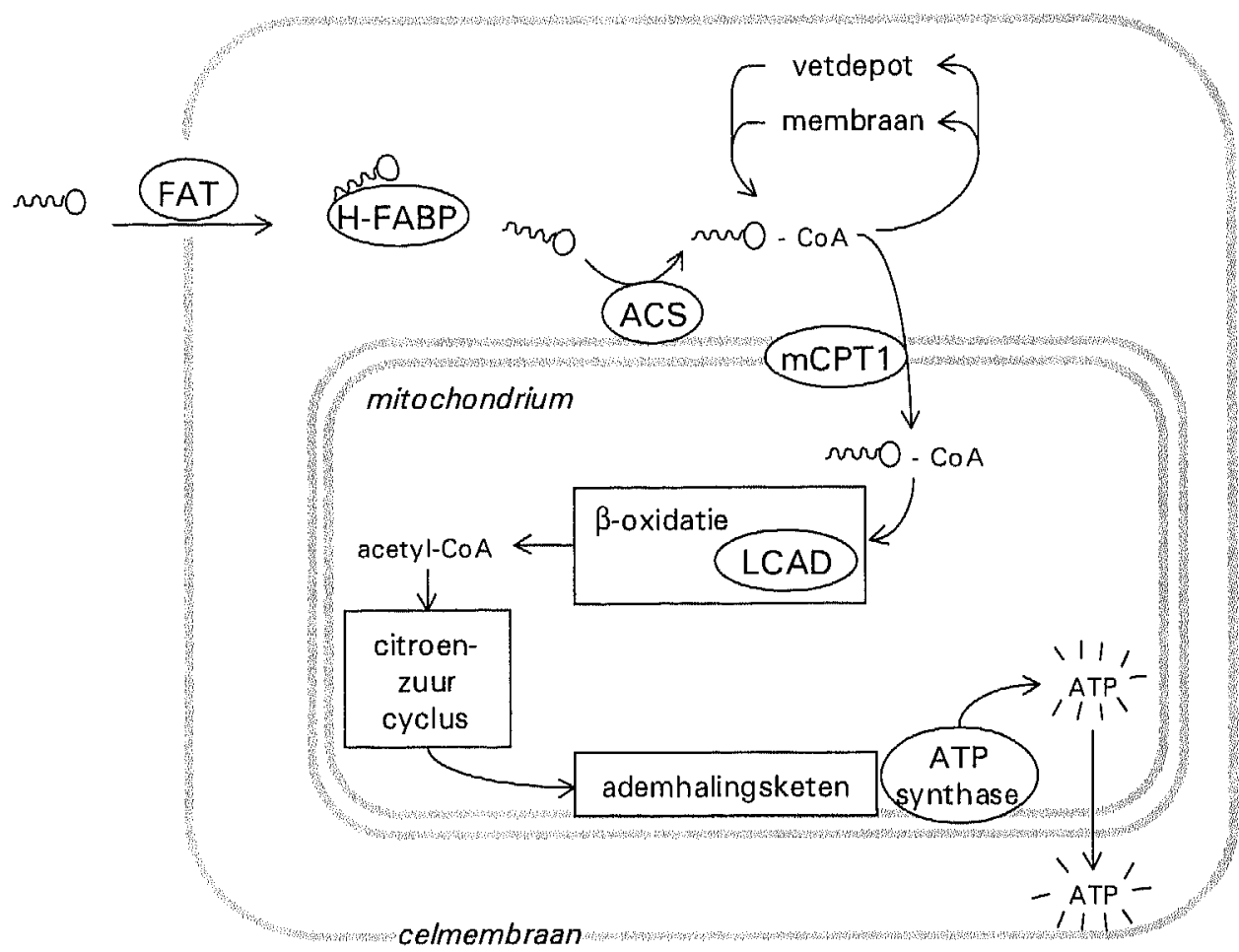

Schematische voorstelling van transport en afbraak van vetzuren in de hartspiercel. FAT, vetzuur translocase; H-FABP, hart-type vetzuurbindend eiwit; ACS, acyl-CoA synthetase; mCPT1, spier-type carnitine palmitoyl transferase 1; LCAD, langketenig acyl-CoA dehydrogenase; CoA, co-enzym $A$.

het enzym ATP synthase geïnvesteerd in de vorming van ATP, een energierijke fosfaatverbinding.

De snelheid waarmee substraten worden verbruikt is afhankelijk van de activiteit van de enzymen die het substraat omzetten. Deze activiteit kan op verschillende manieren gereguleerd worden. Zo is de aanwezigheid van een bepaald substraat een stimulans voor de bijbehorende enzymen om het substraat om te zetten. Een grote hoeveelheid van het product dat ontstaat uit zo'n enzymatische reactie kan de activiteit van het enzym daarentegen juist remmen. De activiteit van een enzym kan ook veranderd worden door de structuur van het enzym te veranderen. Deze mechanismen hebben allemaal op de korte termijn een effect. Op de lange termijn (uren tot dagen) kan echter ook de hoeveelheid enzym aangepast worden. Dit kan door de snelheid van vertaling van mRNA in eiwit te veranderen, maar ook door het aflezen van een gen te beïnvloeden (zie kader voor toelichting).

Van verschillende hormonen, zoals insuline en het schildklierhormoon, is bekend dat ze de transcriptie kunnen reguleren van genen die coderen voor eiwitten betrokken bij de afbraak van vetzuren. Recent is gebleken dat niet alleen hormonen, maar ook vetzuren zelf de expressie van deze genen kunnen reguleren in levercellen, 
vetcellen en skeletspiercellen. Er zijn zelfs transcriptiefactoren ontdekt waar vetzuren aan kunnen binden. Deze transcriptiefactoren worden peroxisome proliferator geactiveerde receptoren (PPARs) genoemd. $\mathrm{Na}$ binding van een vetzuur, wordt een PPAR geactiveerd. Een geactiveerd PPAR kan in de niet-coderende regio van een gen een bepaald gebied herkennen en er een interactie mee aangaan. Dat gebied is bestempeld als een peroxisome proliferator responsief element (PPRE), Door deze interactie kan de transcriptie van het betreffende gen gestimuleerd worden, waardoor er meer mRNA wordt gevormd. Vetzuren zouden de expressie van genen dus via PPAR kunnen reguleren.

In dit proefschrift zijn een aantal studies gepresenteerd die betrekking hebben op bovenstaande gegevens. Het eerste hoofdstuk is een uitgebreide inleiding, waarin de hypothesen staan die voorafgaand aan het onderzoek werden geformuleerd. De belangrijkste daarvan zijn de volgende:

1. Vetzuren verhogen de expressie van genen die coderen voor eiwitten betrokken

bij het transport en de afbraak van vetzuren in gekweekte hartspiercellen;

2. PPARs zijn betrokken bij de door vetzuren geïnduceerde veranderingen in mRNA gehaltes in hartspiercellen;

3. Vetzuren kunnen de hoeveelheid mRNA van UCP-2, een eiwit met een nog onbekende functie, in het hart verhogen;

4. Wanneer de vetzuurspiegels in het bloed stijgen, resulteert dit in een toename in de genexpressie van vetzuurtransporterende en -afbrekende eiwitten in het hart.

De studies die beschreven zijn in hoofdstuk $3 \mathrm{t} / \mathrm{m} 6$ zijn opgezet om bovenstaande hypothesen te toetsen. In hoofdstuk 2 wordt dieper ingegaan op de theorie van de vetzuur-gereguleerde genexpressie in het hart. Het legt de nadruk op de rol die PPARs hierbij kunnen spelen.

Om te testen of vetzuren ook in hartspiercellen de expressie van genen kunnen beïnvloeden, is gebruik gemaakt van hartspiercellen van pasgeboren ratten (hoofdstuk 3). Deze cellen kunnen namelijk relatief eenvoudig gekweekt worden in een laboratoriumschaaltje. Voor dit onderzoek zijn ze blootgesteld aan verschillende substraten: glucose, vetzuren of een combinatie van glucose en vetzuren. De mRNA gehaltes van een aantal eiwitten die betrokken zijn bij het transport (FAT, H-FABP) en de afbraak (ACS, LCAD) van vetzuren bleken inderdaad hoger te zijn in de hartspiercellen die waren blootgesteld aan vetzuren, dan in de cellen die alleen aan glucose waren blootgesteld. Met deze bevinding kan de eerste hypothese dus bevestigd worden.

Vervolgens is het mechanisme, dat achter de door vetzuren veroorzaakte veranderingen in genexpressie zou kunnen zitten, onderzocht. De resultaten hiervan staan beschreven in hoofdstuk 4 . Zoals gezegd bestaan er transcriptiefactoren waaraan vetzuren kunnen binden, de PPARs. Er zijn drie PPAR subtypen bekend: PPAR $\alpha$, PPAR $\beta / \delta$ en PPAR $\gamma$. Alleen PPAR $\alpha$ en PPAR $\beta / \delta$ blijken aanwezig te zijn in hartspiercellen. Blootstelling van de gekweekte rattenhartspiercellen aan chemische stoffen, die specifiek aan één van de drie PPAR subtypen kunnen binden, bevestigt dit. Een stof die alleen kan binden aan PPAR $\gamma$ had namelijk geen effect op de expressie van de onderzochte genen. Daarentegen verhoogden de PPAR $\alpha$ - en PPAR $\beta / \delta$-specifieke stoffen, net zoals vetzuren, de mRNA gehaltes van ACS en LCAD 
in de hartspiercellen. Deze resultaten geven aan dat PPARs daadwerkelijk betrokken zouden kunnen zijn bij de door vetzuren geïnduceerde veranderingen in genexpressie.

UCP-2 (uncoupling protein-2 ofwel ontkoppelingseiwit-2) is een eiwit met een tot nu toe nog onbekende functie in de hartspiercel. Wel is bekend dat dit eiwit ATP synthase ontkoppelt van de ademhalingsketen, waardoor er minder ATP geproduceerd kan worden. $\mathrm{Er}$ is geopperd dat UCP-2 een rol zou kunnen spelen bij de omzetting van vetzuren. Daarom is in de in hoofdstuk 5 beschreven studie gekeken of vetzuren ook het mRNA gehalte van dit eiwit kunnen verhogen. In gekweekte rattenhartspiercellen bleek dit inderdaad het geval te zijn. In het rattenhart zelf bleek de hoeveelheid UCP-2 mRNA toe te nemen na de geboorte. Dit zou kunnen worden veroorzaakt door een stijging van de vetzuurspiegels in het bloed van de dieren, zodra ze moedermelk gaan drinken. Een verandering van de vetzuurspiegels in een volwassen rat, resulteerde echter niet in een verandering in de expressie van UCP-2. Met deze bevindingen kan de derde hypothese daarom slechts gedeeltelijk bevestigd worden.

De effecten van vetzuren op de expressie van genen die coderen voor eiwitten, waarvan bekend is dat ze betrokken zijn bij vetzuurtransport of -afbraak, zijn alleen nog bestudeerd in gekweekte hartspiercellen. Het is de vraag of vetzuren ook een effect hebben op de genexpressie in het hart van een levend dier. Tijdens vasten stijgen de vetzuurspiegels in het bloed van een dier. Ook neemt dan de afbraak van vetzuren in het hart toe. In hoofdstuk 6 is te zien dat de mRNA gehaltes van FAT, HFABP, mCPT1 en LCAD eveneens toenemen in het rattenhart na twee dagen vasten. Door de dieren gedurende de laatste acht uur van de vastenperiode te behandelen met de stof nicotinezuur, dalen de vetzuurspiegels weer. Dit resulteert echter niet in een daling van de mRNA gehaltes naar hun oorspronkelijke waarden. In deze studie kan daarom niet worden vastgesteld dat vetzuren zelf verantwoordelijk zijn voor de veranderingen in de expressie van genen in het hart. Wel is bewezen, dat de toename in de afbraak van vetzuren in het hart tijdens vasten zijn oorsprong al kan hebben op het niveau van genexpressie.

In het laatste hoofdstuk van dit proefschrift, hoofdstuk 7, zijn de voornaamste bevindingen nog eens bediscussieerd. Tevens zijn hierin een aantal suggesties gegeven voor eventuele vervolgstudies. Zo zou de rol die PPARs spelen in de vetzuurgemedieerde genexpressie in het hart nader onderzocht moeten worden. Ook is de mogelijkheid nog niet uitgesloten dat andere mechanismen dan PPARs bij de vetzuurgemedieerde genexpressie betrokken zijn. Verder zou het interessant zijn om de rol die vetzuren zouden kunnen hebben in het ontstaan van ziekten als hartfalen nader te onderzoeken.

Tot slot de belangrijkste conclusie uit dit proefschrift: vetzuren zijn in staat om hun eigen afbraak in hartspiercellen al op een zeer basaal niveau te reguleren, namelijk op het niveau van genexpressie. 


\section{Van DNA naar eiwit}

In de kern van een hartspiercel van de mens bevinden zich 23 paar chromosomen. Elk chromosoom is opgebouwd uit twee strengen DNA die als een spiraal om elkaar heen zijn gedraaid. Op zo'n chromosoom bevinden zich vele genen. In totaal zijn dit er bij de mens 30000 tot 40000 . Een gen bevat de code (genetische informatie) voor de vorming van éen of meer eiwitten. Zo zijn er genen die coderen voor de transporteiwitten en enzymen die in dit proefschrift ter sprake komen. Een gen is op een bepaalde manier opgebouwd. De basis hiervan is het gedeelte dat codeert voor het eiwit, de zogenaamde coderende regio.

Om eiwit te kunnen vormen, wordt de coderende regio van een gen eerst overgeschreven van DNA in RNA, een proces dat transcriptie wordt genoemd. RNA draagt dezelfde code als het DNA, maar is mobieler en daardoor makkelijker verplaatsbaar naar de plek waar het eiwit wordt geproduceerd. Alvorens dit precursor-RNA verplaatst wordt, wordt het eerst nog bewerkt. Het bewerkte RNA wordt boodschapper RNA (messenger RNA; mRNA) genoemd. Het mRNA draagt de gecodeerde boodschap over aan een machinerie, die de code uiteindelijk vertaalt ("transleert") in eiwit.

Het resterende deel van een gen, de niet-coderende regio, is betrokken bij de regulatie van de transcriptie. Hierin bevinden zich allerlei gebieden die herkend worden door specifieke transcriptiefactoren. Deze transcriptiefactoren kunnen aan de gebieden binden en er vervolgens voor zorgen dat de vorming van RNA wordt gestimuleerd of geremd. Op deze manier kunnen ze de expressie van genen beinvloeden.

coderende reglo

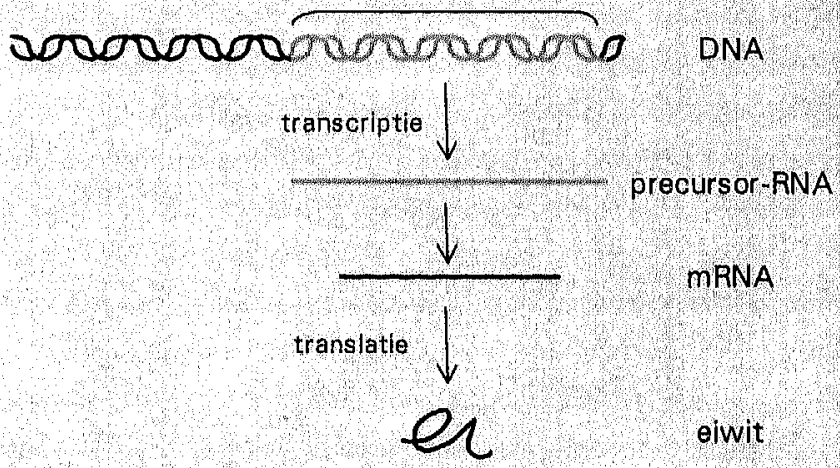




\section{Publications}

\section{Papers}

Van der Lee KAJM, Vork MM, de Vries JE, Willemsen PHM, Glatz JFC, Reneman RS, van der Vusse GJ, and van Bilsen $M$ (2000). Long-chain fatty acid-induced changes in gene expression in neonatal cardiac myocytes. / Lipid Res 41, 41-47

Van der Lee KAJM, Willemsen PHM, van der Vusse GJ, and van Bilsen M (2000). Effects of fatty acids on uncoupling protein-2 expression in the rat heart. FASEB / 14, 495-502

Van der Lee KAJM, de Brouwer KFJ, van der Vusse GJ, and van Bilsen M (2000). Fatty acid-regulated gene expression in the heart:: involvement of peroxisome proliferatoractivated receptors. Recent Res Devel Lipids 4, 25-38

Van der Lee KAJM, Willemsen PHM, Samec S, Seydoux J, Dulloo AG, Pelsers MMAL, Glatz JFC, van der Vusse $G J$, and van Bilsen $M$ (2001). Fasting-induced changes in the expression of genes controlling substrate metabolism in the rat heart. Submitted for publication

\section{Book section}

Van Bilsen M, van der Lee KAJM, and van der Vusse GJ (1999). Long-chain fatty acids and signal transduction in the cardiac muscle cell. In Cardiovascular specific gene expression. Doevendans PA, Reneman RS, and van Bilsen M, Eds. Kluwer Academic Publishers, Dordrecht, the Netherlands, 257-268

\section{Abstracts}

Van Bilsen $M$, Vork MM, van der Lee KAJM, Willemsen PHM, and van der Vusse G] (1999). Fatty acid-mediated changes in neonatal cardiomyocyte gene expression. I Mol Cell Cardiol 31, A69

Van der Lee KAJM, Willemsen PHM, van der Vusse GJ, and van Bilsen M (1999). Modulation of gene expression by fatty acids in non-differentiated and differentiated cardiac-derived H9c2 cells. I Mol Cell Cardiol 31, A69 
Willemsen PHM, van der Lee KAJM, van der Vusse G), Samec $S$, and van Bilsen $M$ (1999). Fasting affects metabolic gene expression in the rat heart. / Mol Cell Cardiol 31, A89

Van der Lee KAJM, Willemsen PHM, van der Vusse GJ, and van Bilsen $M$ (1999). Expression of uncoupling protein 2 in the heart: regulation by fatty acids? / $\mathrm{Mo} / \mathrm{Cell}$ Cardiol 31, A118

Van der Lee KAJM, Willemsen PHM, van der Vusse C), and van Bilsen $M$ (1999). Fatty acids and uncoupling protein-2 expression in the rat heart. Chem Phys Lipids 101,148

Van der Lee KAJM, Willemsen PHM, van der Vusse G), and van Bilsen $M(2000)$. Effects of fatty acids on the embryonic rat heart-derived $\mathrm{H} 9 \mathrm{c} 2$ cells. FASEB J 14, A734

Van der Lee KAJM, Willemsen PHM, van der Vusse GJ, and van Bilsen M (2000). is cardiac uncoupling protein-2 expression regulated by fatty acids? FASEB / 14, A756 


\section{Curriculum vitae}

Karin van der Lee was born in Veghel, the Netherlands, on February 4, 1973. She completed her secondary education at the Comenius College in Uden in 1991. In the same year, she started the study Biology at the Catholic University Nijmegen, with as specialisation Medical Biology. She did major internships at the section of Medical Parasitology (department of Medical Microbiology, Academic Hospital Nijmegen) and at the department of Animal Physiology (Catholic University Nijmegen). In addition, she did a minor internship at the Applied Microbiology Unit in cooperation with the Muhimbili Medical Centre at the University of Dar es Salaam, Tanzania. After she obtained her MSc degree in 1996, she started as a PhD student at the department of Physiology at the Maastricht University. The experimental work carried out until December 2000 is presented in this thesis. Currently, she is working as a postdoc researcher at the same department.

Karin van der Lee werd op 4 februari 1973 geboren te Veghel en groeide op in Nistelrode. In 1991 behaalde ze haar diploma voor het Voortgezet Wetenschappelijk Onderwijs aan het Comenius College te Uden. In datzelfde jaar startte zij de studie Biologie aan de Katholieke Universiteit Nijmegen. Ze volgde de studierichting Medische Biologie met hoofdvakstages bij de sectie Medische Parasitologie (afdeling Medische Microbiologie, Academisch Ziekenhuis Nijmegen) en de afdeling Moleculaire Dierfysiologie (Katholieke Universiteit Nijmegen). Tevens werd een bijvakstage vervuld bij de Applied Microbiology Unit in samenwerking met het Muhimbili Medical Centre aan de University of Dar es Salaam, Tanzania. Na haar afstuderen in 1996, startte zij als assistent in opleiding bij de afdeling Fysiologie aan de Universiteit Maastricht. Het onderzoek dat aldaar tot december 2000 werd verricht staat beschreven in dit proefschrift. Momenteel is ze als post-doc medewerker werkzaam bij dezelfde afdeling. 


\section{Dankwoord}

Na ruim vier jaar is mijn proefschrift voltooid. Lang niet al het werk dat ik in de afgelopen jaren heb verricht staat erin beschreven. Sommige experimenten wilden maar niet lukken, andere bleken niet reproduceerbaar. Zo zit de wetenschap nou eenmaal in elkaar. Gelukkig stond ik er niet alleen voor. Bij de totstandkoming van dit proefschrift hebben veel mensen mij geholpen. Uiteraard wil ik al deze mensen hiervoor bedanken. Een aantal mensen wil ik hierbij met name noemen.

Marc en Ger, als co-promotor en promotor was jullie rol zeker niet gering. Al was het maar dat jullie mij de kans hebben gegeven om van dit project iets moois te maken. Ook al geloofde ik niet altijd in mijn eigen kunnen, jullie deden dat wel. Jullie enthousiasme voor dit onderwerp was zeker bemoedigend. Bedankt voor de goede begeleiding. Ger, dat je me in één van de vele gecorrigeerde manuscripten eigenwijs hebt genoemd, zal ik beschouwen als een compliment. Marc, het was erg leuk om met je te brainstormen over nieuwe experimenten. Ik ben benieuwd welke allemaal uitgevoerd zullen worden.

Zonder goedkeuring van de beoordelingscommissie was dit proefschrift nooit verschenen. Daarom wil ik de professoren M. Borgers, M. Hofker, W. Saris, J. Smits en B. Staels bedanken voor het kritisch doorlezen van mijn manuscript. Bart Staels, ik waardeer het ook dat u speciaal voor mijn promotie vanuit Lille naar Maastricht komt.

Sonia Samec and Abdul Dulloo, without the hearts of the fasted rats you sent from Switzerland chapter 6 and part of chapter 5 could not have been written. I think we made excellent use of these hearts and hope that the paper will be accepted soon. Sonia, good luck with your baby.

Michaël, in de eerste jaren van mijn aio-periode heb ook jij een begeleidende rol vervuld. Als er weer een experiment mislukt was, motiveerde je me om het nog eens te proberen. Speciale dank ben ik je overigens verschuldigd voor hoofdstuk 3 van dit boekje. Jouw bijdrage hierin was groot. Je pogingen om mijn interesse op te wekken voor verschillende onderwerpen, op wetenschappelijk en niet-wetenschappelijk gebied, heb ik als stimulerend ervaren.

Peter, je hebt me de laatste jaren veel werk uit handen genomen. Zeker in het begin had ik daar moeite mee ("ik kan andere mensen toch niet mijn werk op laten knappen?"). Maar na jouw geruststellende woorden, dat je daar toch voor was, heb ik dankbaar van je northern blot en hybridisatiecapaciteiten gebruik gemaakt. De transfecties zijn nu een hernieuwde uitdaging. Jammer dat die stoere gene-gun in onze handen niet werkte. Leuk dat je nu één van mijn paranimfen wilt zijn.

Marloes, je was mijn eerste en enige stagiaire. Ik vond het erg leuk om je wat te kunnen leren en met je samen te werken. Resultaat van je werk is terug te vinden in dit boekje. Veel succes met het afronden van je studie in Nijmegen.

Jodil, Martijn, Maurice en Theo, bedankt voor jullie hulp bij de computer, cobasbio, northerns, elisa's en lipidbepalingen. Frans, Hans en Richard, bedankt voor de 
boeiende, kritische en leuke discussies. Bart, we hadden allebei nooit gedacht dat reizen met de trein kan resulteren in een vermelding in de acknowledgements.

Alle (oud-)medewerkers van Fysiologie en omgeving wil ik bedanken voor de goede en gezellige omgang met elkaar. Joost en Lilian, zal de "onvoltooide van Mesch" dit jaar nog voltooid worden? Joep, we wachten hier nog op een avondje filmhuis met vooraf een etentje bij "de Branding". Andries, Daniëlle, Danny, Debby, Joep, Kristel, Roy en Susan, veel succes met het afronden van jullie promotie. Frans, Monique, Maaike, Wendy en Xander, bedankt voor de steeds terugkerende etentjes.

Frans, jouw gezelschap heb ik altijd op prijs gesteld. Niet alleen op het werk, maar ook in de trein. Bedankt hiervoor en ook voor alle hulp en adviezen op het wetenschappelijke vlak. Ik hoop dat je toekomst er goed uit zal zien.

Maaike, menig uurtje hebben we samen doorgebracht in de trein van Roermond naar Maastricht en weer terug. We konden ons ei kwijt bij elkaar, wat soms toch echt even nodig is. Ik ben benieuwd of we alle etentjes in stand kunnen blijven houden. Heel fijn dat je mijn andere paranimf wilde zijn.

Familie en vrienden, bedankt voor alle nodige ontspanning. Pap en mam, bedankt voor het er zijn en de altijd welkome thuiskomst.

Walter, lief, je hebt het toch maar mooi op kunnen brengen om de afgelopen jaren in Roermond te wonen. Fijn dat je er altijd voor me was. Nu op naar een nieuwe fase in ons leven.

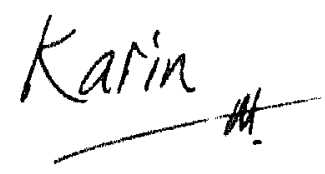

